OAK RIDGE

NATIONAL

LABORATORY

MARTIN MARIETTA

SCALE-4 Analysis of Pressurized Water Reactor Critical Configurations:

Volume 2 - Sequoyah Unit 2 Cycle 3

\author{
S. M. Bowman \\ O. W. Hermann \\ M. C. Brady
}


This report has been reproduced directly from the best available copy.

Available to DOE and DOE contractors from the Office of Scientific and Technical Information, P.O. Box 62, Oak Ridge, TN 37831; prices available from (615) 576-8401.

Available to the public from the National Technical Information Service, U.S. Department of Commerce, 5285 Port Royal Rd., Springfield, VA 22161.

\footnotetext{
This report was prepared as an account of work sponsored by an agency of the United States Government. Neither the United States nor any agency thereof, nor any of their employees, makes any warranty, express or implied, or assumes any legal liability or responsibility for the accuracy, completeness, or usefulness of any information, apparatus, product, or process disclosed, or represents that its use would not infringe privately owned rights. Reference herein to any specific commercial product, process, or service by trade name, trademark, manufacturer, or otherwise, does not necessarily constitute or imply its endorsement, recommendation, or favoring by the United States Government or any agency thereof. The views and opinions of authors expressed herein do not necessarily state or reflect those of the United States Government or any agency thereof.
} 
Computational Physics and Engineering Division

\title{
SCALE-4 ANALYSIS OF PRESSURIZED WATER REACTOR CRITICAL CONFIGURATIONS: VOLUME 2 -SEQUOYAH UNIT 2 CYCLE 3
}

\author{
S. M. Bowman \\ O. W. Hermann \\ M. C. Brady
}

* Currently at Sandia National Laboratories, Las Vegas, Nevada.

Date Completed: January 1995

Date Published: March 1995

\begin{abstract}
Prepared under the direction of
Sandia National Laboratories

under Memorandum Purchase Orders 66-0162 and AD-4072

with Oak Ridge National Laboratory
\end{abstract}

Prepared by the
OAK RIDGE NATIONAL LABORATORY
managed by
MARTIN MARIETTA ENERGY SYSTEMS, INC.
for the
U.S. DEPARTMENT OF ENERGY
under contract DE-AC05-84OR21400





\section{CONTENTS}

Page

LIST OF FIGURES LIST OF TABLES ABSTRACT

1. INTRODUCTION

2. OVERVIEW OF THE METHODOLOGY

2.1 FUEL ASSEMBLY GROUPS

2.2 DEPLETION CALCULATIONS

2.3 NUCLIDE CONCENTRATIONS FOR REACTOR

CRITICALITY CALCULATIONS

2.4 CROSS-SECTION PROCESSING BY CROSS-SECTION SET . . . . . . . . . . 10

2.5 PREPARATION OF THE KENO V.a CORE MODEL

3. PREPARATION OF THE SEQUOYAH 2 CYCLE 3 CORE MODEL . . . . . . . . . . 13

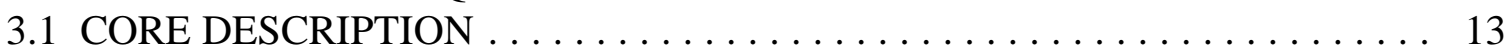

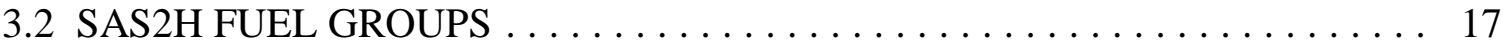

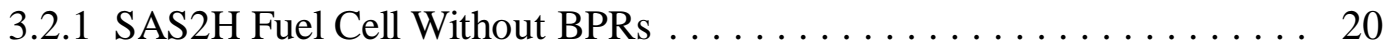

3.2 .2 SAS2H Fuel Cell With BPRs ...................... 20

3.3 SIMILAR-BURNUP SUBGROUPING FOR CROSS-SECTION SETS . . . . . . 24

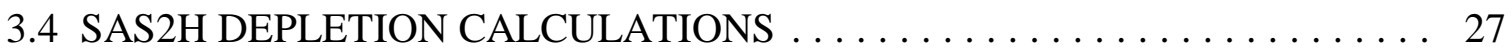

3.5 BURNUP-DEPENDENT INTERPOLATIONOFISOTOPICS $\ldots \ldots \ldots \ldots .27$

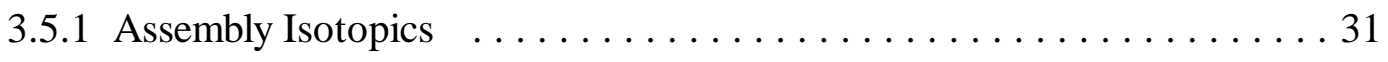

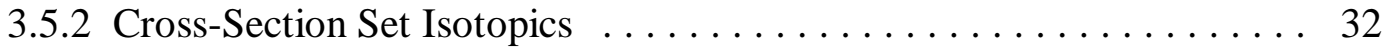

3.6 GENERATION OF CROSS SECTIONS USING CSASN $\ldots \ldots \ldots \ldots \ldots \ldots .32$

3.7 COMBINING CROSS-SECTION SET LIBRARIES USING WAX . . . . . . . . 33

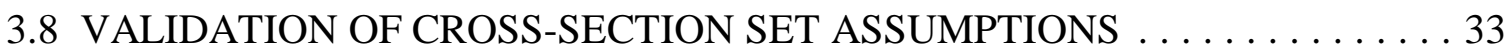

3.9 PREPARATION OF KENO V.a CORE MODEL $\ldots \ldots \ldots \ldots \ldots \ldots \ldots \ldots \ldots . \ldots$

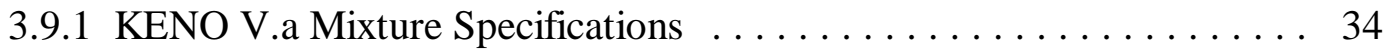

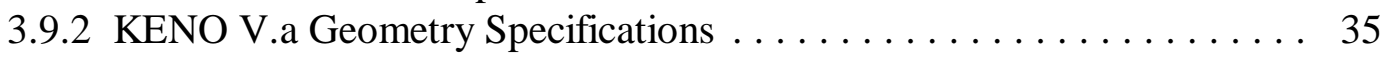

4. RESULTS AND CONCLUSIONS $\ldots \ldots \ldots \ldots \ldots \ldots \ldots \ldots \ldots \ldots \ldots \ldots$

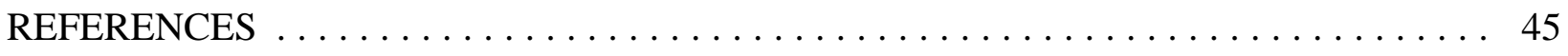

APPENDIX A. SEQUOYAH UNIT 2 CYCLE DATA . . . . . . . . . . . . . . . . . . 49

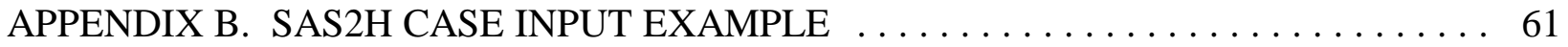

APPENDIX C. SNIKR VERSION 1.0 DOCUMENTATION $\ldots \ldots \ldots \ldots \ldots \ldots \ldots \ldots . \ldots 67$

APPENDIX D. KENO V.a BOC MODEL SETUP INPUT EXAMPLES . . . . . . . . . . . .999

APPENDIX E. KENO V.a MOC MODEL SETUP INPUT EXAMPLES . . . . . . . . . . 177 


\section{LIST OF FIGURES}

\section{Figure}

Page

1. Overview of the reactor-critical calculation procedure $\ldots \ldots \ldots \ldots \ldots$

2. $\quad$ SAS2H burnup model of assemblies within a fuel group $\ldots \ldots \ldots \ldots \ldots \ldots$

3. Sequoyah Unit 2 Cycle 3 core configuration $\ldots \ldots \ldots \ldots \ldots \ldots \ldots \ldots \ldots \ldots$

4. Fuel assembly lattice arrangements in Sequoyah Unit 2 Cycle $3 \ldots \ldots \ldots 15$

5. Sequoyah Unit 2 Cycle 3 burnable poison loading configuration $\ldots \ldots \ldots \ldots \ldots$

$6 . \quad$ Sequoyah Unit 2 eighth-core symmetric configuration $\ldots \ldots \ldots \ldots \ldots \ldots$

7. $\quad$ Full-core assembly positions and core baffle configuration $\ldots \ldots \ldots \ldots \ldots \ldots$. . . . 37

8. $\quad$ KENO V.a unit definitions based on component arrays $\ldots \ldots \ldots \ldots \ldots \ldots$

9. $\quad$ BOC, HZP eighth-core relative fission density distribution $\ldots \ldots \ldots \ldots \ldots \ldots \ldots$

10. $\quad$ BOC, HFP eighth-core relative fission density distribution $\ldots \ldots \ldots \ldots \ldots \ldots \ldots$

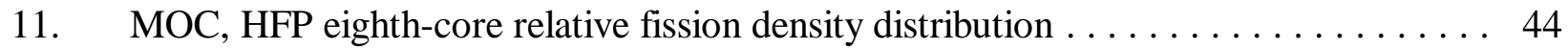

A.1. Sequoyah Unit 2, Cycle 1, boron letdown curve $\ldots \ldots \ldots \ldots \ldots \ldots \ldots \ldots$

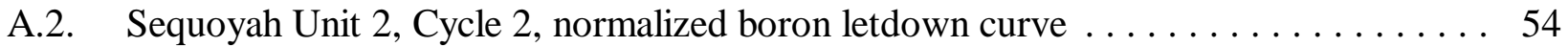

A.3. $\quad$ Sequoyah Unit 2, Cycle 3, boron letdown curve $\ldots \ldots \ldots \ldots \ldots \ldots \ldots \ldots$

A.4. Sequoyah Unit 2, Cycle 1, initial core loading pattern $\ldots \ldots \ldots \ldots \ldots \ldots$

A.5. Sequoyah Unit 2, Cycle 2 , initial core loading pattern $\ldots \ldots \ldots \ldots \ldots \ldots 7$

A.6. Sequoyah Unit 2, Cycle 3, initial core loading pattern . . . . . . . . . . . . . . . 58

A.7. Sequoyah Unit 2, Cycle 1, final burnup distribution $\ldots \ldots \ldots \ldots \ldots \ldots \ldots$. . . . . . 59

A.8. Sequoyah Unit 2, Cycle 2, final burnup distribution $\ldots \ldots \ldots \ldots \ldots$. . . . . . . 60 . 


\section{LIST OF TABLES}

\section{Table}

Page

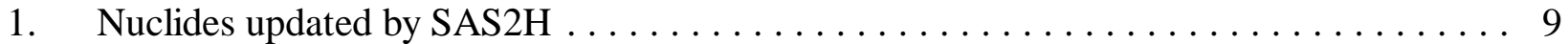

2. $\quad$ Expanded set of fuel nuclides used in KENO V.a calculations $\ldots \ldots \ldots \ldots \ldots \ldots \ldots 11$

3. Sequoyah Unit 2 Cycle 3 measured critical conditions and BOC and MOC . . . . . . 17

4. Sequoyah PWR Unit 2 assembly design description $\ldots \ldots \ldots \ldots \ldots \ldots \ldots \ldots \ldots$

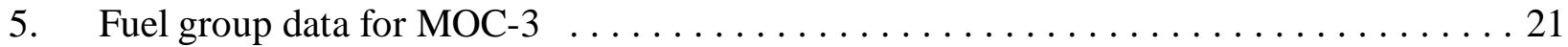

6. $\quad$ Initial uranium isotopic content of fresh fuel $\ldots \ldots \ldots \ldots \ldots \ldots \ldots \ldots \ldots \ldots$

7. $\quad$ Light-element masses used in SAS2H calculations $\ldots \ldots \ldots \ldots \ldots \ldots \ldots \ldots \ldots \ldots \ldots$

8. $\quad$ Borosilicate glass composition in BPR assemblies $\ldots \ldots \ldots \ldots \ldots \ldots \ldots \ldots \ldots$

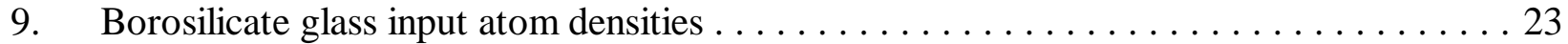

10. Number of BPRs and guide tubes in fuel groups 5 and $7 \ldots \ldots \ldots \ldots \ldots$

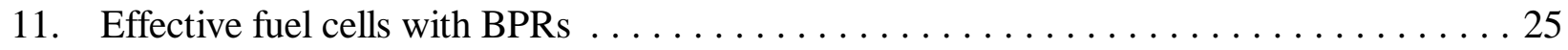

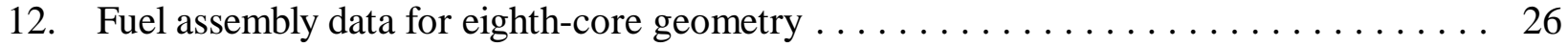

13. Cross-section sets for one-eighth core assemblies $\ldots \ldots \ldots \ldots \ldots \ldots \ldots \ldots$

14. Cross-section sets for Sequoyah Unit 2 Cycle 3 BOC $\ldots \ldots \ldots \ldots \ldots \ldots$. . . . . . . 29

15. Cross-section sets for Sequoyah Unit 2 Cycle 3 MOC . . . . . . . . . . . . . . . . . . . 29

16. SAS2H operating history data by fuel group and cycle $\ldots \ldots \ldots \ldots \ldots \ldots \ldots$

\begin{tabular}{lll}
\hline 17. & $\mathrm{k}_{\infty}$ comparison for validation of cross-section methodology $\ldots \ldots \ldots \ldots \ldots \ldots \ldots$ \\
\hline
\end{tabular}

18. Mixtures in KENO V.a model $\ldots \ldots \ldots \ldots \ldots \ldots \ldots \ldots \ldots \ldots \ldots \ldots \ldots$

19. Unit numbers used in Sequoyah KENO V.a core model . . . . . . . . . . . . . . . . . . . 39

20. KENO V.a calculated results for Sequoyah Unit 2 Cycle $3 \ldots \ldots \ldots \ldots \ldots \ldots$

21 . Range of conditions for Sequoyah reactor criticals $\ldots \ldots \ldots \ldots \ldots \ldots \ldots \ldots \ldots$

A.1. Fuel assembly burnups at restart during Cycle 3 of Sequoyah Unit $2 \ldots \ldots \ldots \ldots$

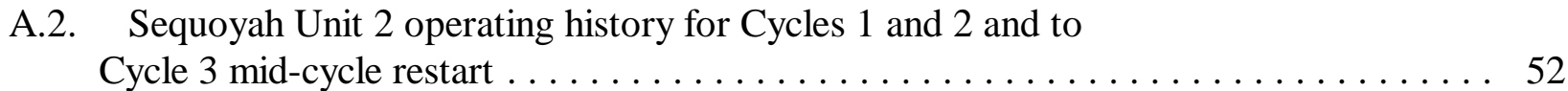

D.1. SNIKR/ORIGEN-S input for fresh fuel batch/assembly isotopics . . . . . . . . . . 100

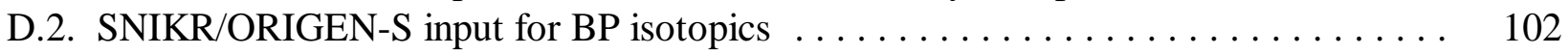

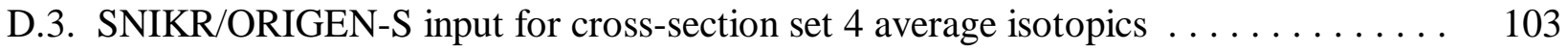

D.4. CSASN input for cross-section sets with important actinides only . . . . . . . . . . 105

D.5. CSASN input for cross-section set $4 \ldots \ldots \ldots \ldots \ldots \ldots \ldots \ldots$

D.6. WAX input for cross-section-library generation $\ldots \ldots \ldots \ldots \ldots \ldots \ldots \ldots$

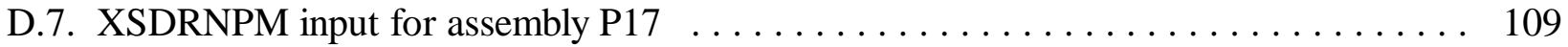

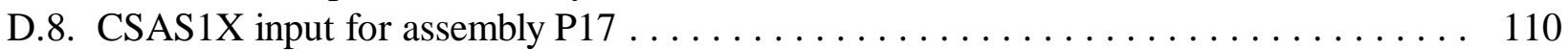

D.9. KENO V.a input file for BOC, HZP $\ldots \ldots \ldots \ldots \ldots \ldots \ldots \ldots \ldots \ldots \ldots \ldots \ldots 111$

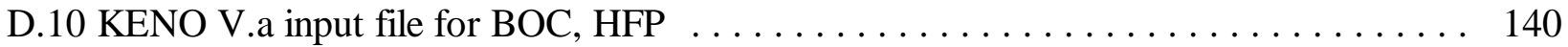

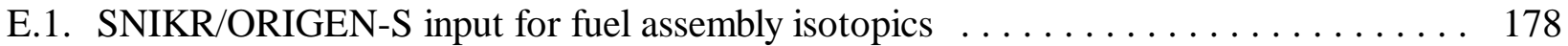

E.2. SNIKR/ORIGEN-S input for BP isotopics $\ldots \ldots \ldots \ldots \ldots \ldots \ldots \ldots \ldots \ldots \ldots$

E.3. SNIKR/ORIGEN-S input for average cross-section set isotopics . . . . . . . . . . . 182

E.4. CSASN input for cross-section sets with important actinides only . . . . . . . . . . . 184

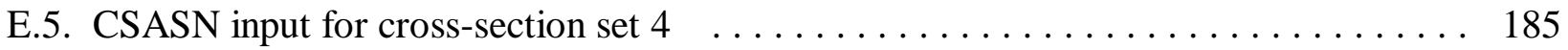


E.6. WAX input for cross-section-library generation $\ldots \ldots \ldots \ldots \ldots \ldots \ldots \ldots \ldots \ldots \ldots \ldots$

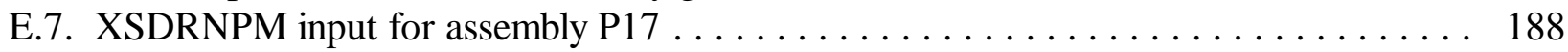

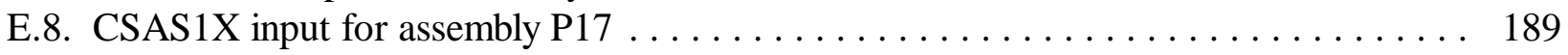

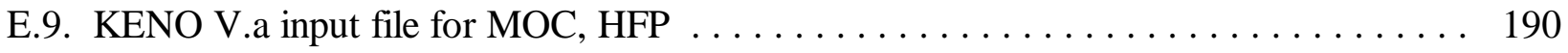




\begin{abstract}
The requirements of ANSI/ANS 8.1 specify that calculational methods for away-from-reactor criticality safety analyses be validated against experimental measurements. If credit for the negative reactivity of the depleted (or spent) fuel isotopics is desired, it is necessary to benchmark computational methods against spent fuel critical configurations. This report summarizes a portion of the ongoing effort to benchmark away-from-reactor criticality analysis methods using critical configurations from commercial pressurized-water reactors.

The analysis methodology selected for all the calculations reported herein is based on the codes and data provided in the SCALE-4 code system. The isotopic densities for the spent fuel assemblies in the critical configurations were calculated using the SAS2H analytical sequence of the SCALE-4 system. The sources of data and the procedures for deriving SAS2H input parameters are described in detail. The SNIKR code module was used to extract the necessary isotopic densities from the SAS2H results and provide the data in the format required by the SCALE criticality analysis modules. The CSASN analytical sequence in SCALE-4 was used to perform resonance processing of the cross sections. The KENO V.a module of SCALE-4 was used to calculate the effective multiplication factor $\left(\mathrm{k}_{\mathrm{eff}}\right)$ of each case. The SCALE-4 27-group burnup library containing ENDF/B-IV (actinides) and ENDF/B-V (fission products) data was used for all the calculations.

This volume of the report documents the SCALE system analysis of three reactor critical configurations for the Sequoyah Unit 2 Cycle 3. This unit and cycle were chosen because of the relevance in spent fuel benchmark applications: (1) the unit had a significantly long downtime of 2.7 years during the middle of cycle (MOC) 3, and (2) the core consisted entirely of burned fuel at the MOC restart. The first benchmark critical calculation was the MOC restart at hot, full-power (HFP) critical conditions. The other two benchmark critical calculations were the beginning-of-cycle (BOC) startup at both hot, zero-power (HZP) and HFP critical conditions. These latter calculations were used to check for consistency in the calculated results for different burnups and downtimes. The $\mathrm{k}_{\text {eff }}$ results were in the range of 1.00014 to 1.00259 with a standard deviation of less than 0.001 .
\end{abstract}




\section{INTRODUCTION}

In the past, criticality analysis of pressurized-water-reactor (PWR) fuel in storage or transport has assumed that the fuel is fresh with the maximum allowable initial enrichment. This assumption has led to the design of widely spaced and/or highly poisoned storage and transport arrays. If credit is assumed for fuel burnup, more compact and economical arrays can be designed. Such reliance on the reduced reactivity of spent fuel for criticality control is referred to as "burnup credit." If burnup credit is applied in the design of a cask for use in the transport of spent light-water-reactor (LWR) fuel to a repository, a significant reduction both in the cost of transport and in the risk to the public can be realized 1 These benefits caused the U.S. Department of Energy (DOE) to initiate a program to investigate the technical issues associated with burnup credit in spent fuel cask design. These efforts have been led by Sandia National Laboratories (SNL) and carried out as part of the Cask Systems Development Program within the Office of Civilian Radioactive Waste Management. This five-volume report documents work performed at Oak Ridge National Laboratory (ORNL) as part of a larger effort to demonstrate an acceptable approach for validating computational tools to be used in burnup credit cask design.

The computational tools of interest for burnup credit cask design are initially those currently used and accepted for spent fuel characterization (prediction of isotopics) and criticality safety (prediction of the effective multiplication factor, $\mathrm{k}_{\text {eff }}$ ) in away-from-reactor (AFR) applications. The criticality analysis tools accepted for fresh fuel cask design have typically been validated per the requirements of the ANSI/ANS-8.1 criticality safety standard (i.e., comparison against experimental data). Numerous critical experiments for fresh PWR-type fuel in storage and transport configurations exist and can be used as part of a validation data base. However, there are no critical experiments with burned PWR-type fuel in storage and transport configurations that can be directly used to extend the data base to the realm of burned fuel. Thus, as part of the effort to extend the validation of existing criticality analysis tools to the domain of burned fuel, it was decided to investigate the performance of AFR analysis methods in the prediction of measured reactor critical configurations. While elements of a reactor critical analysis do not directly correspond to analyses of spent fuel assemblies in transportation and storage casks (e.g., elevated temperatures in reactor configurations or poison plates in cask designs), comparison against measured critical configurations can be used to validate aspects of spent fuel cask configurations which are not addressed in other experiments (i.e., fission-product interactions and the prediction of time-dependent actinide and fission-product inventories). Reactor critical configurations contain a diverse range of nuclides, including fissile and fertile actinides, fission products, and activation products. Thus, nuclear reactor core criticals can be used to test the ability of a methodology to generate accurate burned fuel isotopics and handle the reactivity effects of complex heterogeneous systems containing burned fuel.

This report describes the data and procedures used to predict the multiplication factor for several measured critical core configurations using a select set of AFR analysis codes. The analyses were performed for precise state points at beginning of cycle (BOC) (mixture of fresh and burned fuel) and at measured state points throughout the cycle depletion (all burned fuel). Self-consistency among the reactor criticals in the prediction of $k_{\text {eff }}$ will allow the determination of the bias of the approach taken in representing the effect of those materials not present in fresh fuel. 
To date, the SCALE code systen ${ }^{3}$ developed at ORNL has been the primary computational tool used by DOE to investigate technical issues related to burnup credit 4 SCALE is a wellestablished code system that has been widely used in AFR applications for spent fuel characterization via the SAS2H/ORIGEN-S analysis sequence 5 and criticality safety analyses via the CSAS/KENO V.a analysis sequence 6 The isotopic composition of the spent fuel is derived from a SAS2H/ORIGEN-S calculation that simulates two-dimensional (2-D) effects in a one-dimensional (1-D) model of an LWR fuel assembly. The depletion model is a spatially independent point model using cross sections and neutron flux parameters derived from the 1-D fuel assembly model. The KENO V.a Monte Carlo $\operatorname{code}^{7}$ is used to calculate the neutron multiplication factor for complex multidimensional systems. KENO V.a has a large degree of flexibility in its geometrical modeling capabilities which enables spent fuel arrays and container geometries to be modeled in explicit detail. The SCALE-4 27-group burnup library containing ENDF/B-IV (actinides) and ENDF/B-V (fission products) data was used for all calculations.

Early efforts to analyze reactor criticals 8 using the SCALE modules concentrated on using utility-generated isotopic data although some analyses were performed using isotopics calculated with SAS2H. Based on this initial work, a consistent SCALE-based analysis methodology that simplifies both the data requirements and the calculational procedure was developed. The criteria used to select the reactor critical configurations were (1) applicability to the PWR fuel to be used in burnup credit cask design (e.g., long downtimes for decay of short-lived isotopes, large percentages of burned fuel in the configuration), the need to verify consistency in calculated results for different reactor conditions, and the need to provide a comparison with the results of ref. 8. Acceptable performance of the SCALE system in the prediction of $\mathrm{k}_{\text {eff }}$ will be judged relative to established SCALE performance for fresh fuel systems; if agreement is seen within the range typical for fresh fuel systems, then it will be concluded that the methodology described herein is valid in terms of its treatment of depletion and decay calculations and fission-product interactions, within the range of application defined by the reactor conditions.

The purpose of this volume of the report is to describe the analysis of three reactor critical configurations from the Tennessee Valley Authority's Sequoyah Unit 2 Cycle 3. This particular unit and cycle were chosen because the unit had a significantly long downtime of 2.7 years during the middle-of-cycle (MOC) 3, and no fresh fuel was loaded into the reactor prior to restart. The 2.7-year downtime prior to restart ensures that the decay of short-lived nuclides have occurred to a similar level of insignificance as found in the minimum-cooled (5-year) spent fuel planned for transport. A methodology resulting in proper characterization of in-core depletion and post-discharge decay is necessary in order to accurately predict criticality for this configuration. Successful prediction of the critical condition may therefore be used as an indication of the validity of this methodology for spent fuel applications where long decay times are involved. The first benchmark critical calculation was the MOC restart at hot, full-power (HFP) critical conditions. The other two benchmark critical calculations were the BOC startup at both hot, zero-power (HZP) and HFP critical conditions. These latter calculations were used to check for consistency in the calculated results for different burnup, downtime, temperature, and xenon conditions.

Section 2 of this volume presents an overview of the methodology employed in the reactor critical analyses. Section 3 provides the details of the analysis performed for Sequoyah 2 Cycle 3. The results and conclusions are discussed in Sect. 4. 


\section{OVERVIEW OF THE METHODOLOGY}

An essential part of any analysis validation effort is to use the same codes, input options, and technical approach for the validation study as that used for the application. To this end, a straightforward calculational strategy was established that minimizes the data required to characterize the spent fuel and is appropriate for use by a cask designer performing criticality analysis for spent fuel assemblies. The methodology applied in reactor critical analyses can be broken into five steps: (1) grouping of fuel assemblies into similar-content groups and similar-burnup subgroups; (2) calculation of burnup-dependent isotopics for each group; (3) interpolation of decay calculations from results of the previous step to obtain both individual assembly and subgroup isotopics; (4) crosssection processing based on subgroup isotopics; and (5) preparation of a KENO V.a model based on the actual core geometry, individual assembly isotopics, and subgroup-evaluated cross sections. The model developed in step 5 is used to calculate the effective multiplication factor, $\mathrm{k}_{\text {eff }}$, for the reactor.

Figure 1 provides a graphical overview of these steps, showing the relationships between the data and codes used in each stage of the calculation. The first step shown in the figure represents the process of collecting assembly information from reactor documentation. Eighth-core symmetry is assumed to reduce the number of unique assemblies models, such that the burnup of each assembly in an eighth-core segment represents the average burnup of all assemblies located in the corresponding symmetric position across the core. Using the reactor information, "groups" of assemblies are identified which are of cognate background (i.e., same initial loading and burn cycles). These assembly groups are then further categorized into "subgroups" consisting of assemblies within a group with similar ( $\pm 2 \mathrm{GWd} / \mathrm{MTU}$ ) burnups.

The second step shown in the figure involves the calculation of isotopic contents using the decay and depletion steps of the SAS2H calculational sequence of SCALE. Calculations are performed for each assembly group based on the initial fresh fuel content and operating history of the group. Output consists of calculated isotopic contents for each of a number of user specified timesteps.

In the third step, the SNIKR code package (not a part of the SCALE system) is used to interpolate between isotopics for appropriate timesteps in order to obtain the assembly-specific isotopic contents for each assembly to be used in the KENO V.a core model. (SNIKR is a simple tool used to automate the task of extracting, interpolating, and formatting data; however, this process can be performed manually.) SNIKR is also used to calculate the isotopics for the average burnup of each assembly subgroup.

The results of step 3 are used in step four to create fuel pin models based on the average composition of an assembly subgroup; the CSASN sequence in SCALE is then used to calculate the problem-dependent group-weighted cross sections for each subgroup. The SCALE module WAX is then used to combine all subgroup-based cross sections into a single working library, where crosssection identifiers are assigned such that each numeric identifier indicates both a specific isotope and the subgroup upon which it was based.

Finally, in the fifth step, a KENO V.a model is created based on the core geometry, again assuming eighth-core symmetry. Thus, while a full-core model is prepared, each eighth-core segment of the core is identical in composition to the other eighth-core segments. (A full-core model in KENO V.a is more computationally efficient than an eighth-core model with reflective boundary 
ORNL-DWG 94-12309

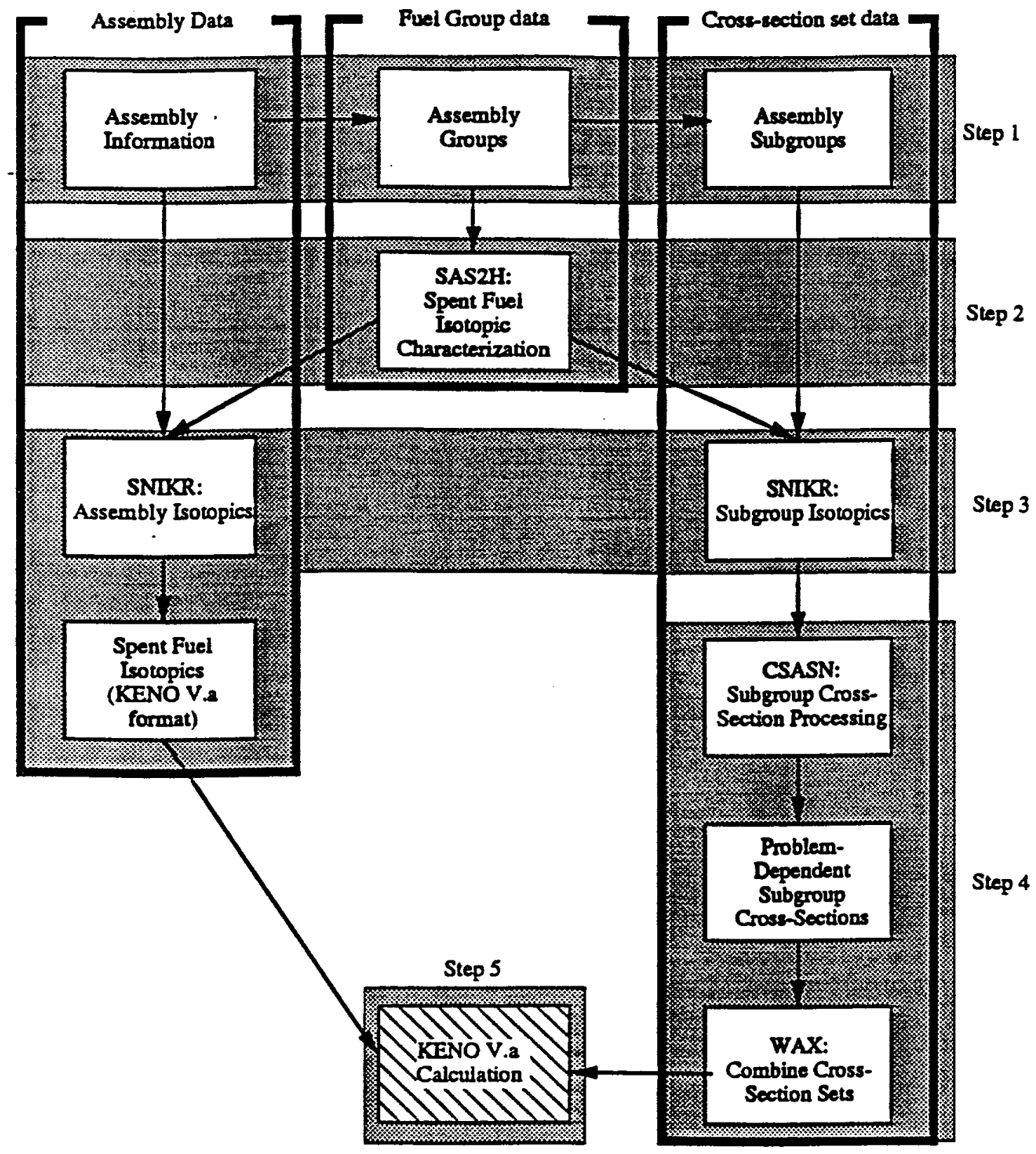

Fig. 1. Overview of the reactor critical calculation procedure. 
conditions.) Fuel assemblies are assumed to be uniform in composition (all fuel pins are comprised of the same material), and isotopics are obtained from the burnup-specific results obtained in step 3. Assembly isotopes are assigned cross-section identifiers corresponding to the appropriate subgroupbased cross sections derived in step 4. Remaining core information is obtained from the reactor documentation. Calculations are then performed to determine the value of $\mathrm{k}_{\text {eff }}$ for the reactor model and to verify that the solution has converged. The specifics of each step as applied in the Sequoyah 2 Cycle 3 analysis are given in Sect. 3 .

\subsection{FUEL ASSEMBLY GROUPS}

Since many assemblies in a reactor begin with identical initial compositions and experience simultaneous operating histories, these similar fuel assemblies can be collected effectively into groups, with one depletion calculation performed for each group. It is assumed that at a given burnup, all assemblies within a group have the same isotopic content. If the isotopic content of a group is known as a function of burnup, then one can interpolate to obtain the specific isotopics for a given assembly burnup. This interpolation is discussed further in Sect. 2.3.

A minimum granularity for grouping is to collect fuel assemblies by reactor fuel batch. In the nomenclature generally applied by commercial PWR core designers, a fuel batch is typically comprised of a single enrichment fuel, all loaded at the same time, and all residing in-core for the same fuel cycles. Three fuel batches (i.e., enrichments) are usually present in the first operating cycle of a reactor. These batches are typically designated by the numbers 1, 2, 3. Prior to each subsequent cycle of operation, one new batch of fuel is usually added and some of the depleted fuel assemblies are removed. Each new batch of fuel is assigned a number unique to that reactor. If the new fuel assemblies to be loaded consist of more than one enrichment, they may be assigned as a "split batch," using the same number with a different letter appended to each enrichment. For example, if two enrichments were to be added to Cycle 2, the fuel assemblies of one enrichment would be designated as batch 4A, and those of the other enrichment would be designated as batch 4B. Hence, if a given batch of assemblies has experienced identical operating periods, downtimes, and roughly the same power history, the batch meets the minimum requirements for a calculational fuel group. However, within a given fuel batch, additional fuel groups (i.e., separate depletion calculations) may be required when absorber materials [i.e., burnable poison rods (BPRs) or control rods] are present in certain assemblies within a fuel batch.

As discussed, within a fuel group it is possible to interpolate between a series of burnups to determine the isotopic concentrations corresponding to a specific burnup. This interpolation procedure can be used to calculate the contents of each individual assembly. Based on these assembly isotopics, it is possible to generate a content-specific cross-section set for each assembly. However, since nuclide cross sections vary slowly with burnup (after the initial startup of approximately $150 \mathrm{MWd} / \mathrm{MTU}$ ) the analysis methodology can be accurately simplified by preparing problemdependent cross sections for a set of similar assemblies with similar burnups. Unfortunately, due to specific power variations related to the assembly locations in the core it is possible to have a relatively wide range of burnups within a single fuel group. Thus, it may be necessary to divide fuel groups into subgroups or cross-section sets based on burnup such that all assemblies included in a cross-section set are within a limited burnup range; the number of cross-section sets will depend on the range of 
burnups contained in the fuel group. Calculations reported in Sect. 3.8 of this report indicate that cross-section sets with burnup ranges of no more than $2 \mathrm{GWd} / \mathrm{MTU}$ can be adequately represented by the average burnup value within the cross-section set.

\subsection{DEPLETION CALCULATIONS}

Depletion calculations were performed using the SAS2 $\mathrm{H}^{5}$ sequence of the SCALE-4 code system and the 27-group burnup library. The SAS2H sequence invokes the ORIGEN-S9 code in order to perform depletion and decay calculations. The SAS2H procedure uses a 1-D two-part spectrum calculation (part 1 is a pin-cell model; part 2 is an assembly model) at selected times in the irradiation history to generate burnup-dependent cross sections based on the given design and operating parameters. At the end of each burnup step, cross sections for default and any userspecified isotopes are reevaluated based on the new isotopic composition. The purpose of these calculations is to predict the isotopic content of each fuel group as a function of its operating history. For fuel groups comprised of fresh (unburned) fuel at the time of the critical measurements, SAS2H calculations are not necessary; the isotopic content is based on that of the fresh fuel specifications.

Although it is necessary to model the presence of BPRs for the cycle for which the criticality calculation is to be performed, previous studie 10,11 have shown that the history of the assembly with respect to the insertion and removal of BPRs in early reactor cycles is small enough to be neglected $(<1 \% \Delta \mathrm{k} / \mathrm{k})$. In order to model the influence of the BPRs in the cycle of interest, an effective cell is derived. This effective cell conserves the mass of the nuclides comprising the BPRs, guide tube, and fuel rods. In this effective cell, the densities of the isotopes remain unchanged, but the rod diameters of the glass and stainless steel in the BPRs are modified appropriately for the 1-D assembly model required by $\mathrm{SAS} 2 \mathrm{H}$.

Since within a fuel group it is assumed that isotopic content is a function of burnup only, it is possible to calculate the content of the fuel at a given burnup by interpolation between SAS2H/ORIGEN-S isotopics provided at each burnup step. The manner of interpolation is discussed in the following subsection. SAS2H provides the capability to obtain the isotopic composition of a fuel at specified burnup intervals given the initial composition of the fuel, clad, and moderator, design parameters of the fuel rod and lattice, and power history. In order to provide sufficient points for interpolation, the burnup history was broken into equal intervals of no more than $5 \mathrm{GWd} / \mathrm{MTU}$. (This should not be confused with the 2-GWd/MTU interval used to establish assembly subgroups. The 5-GWd/MTU interval represents an interpolation range over which isotopic concentrations are assumed to vary smoothly.) The fuel groups were depleted at least 1.2 times the maximum burnup $\left(\mathrm{B}_{\max }\right)$ of the fuel group. Note that it is generally sufficient to calculate burnups out to the maximum burnup in a group, as this will bound all burnups in the group. A value of $1.2 * \mathrm{~B}_{\max }$ was used in order to allow for the capability of modeling axial burnup variations where volume-averaged center region burnups may be up to 1.2 times larger than the assembly average. However, axial burnup variations are not included in the models presented in this report.

To make it possible to interpolate between burnup steps and account for downtime between cycles, a simplification is made in the burnup model. Since the burnup actually accumulated during each cycle varies for each fuel assembly in a group, the downtime was split and applied at the end of each burnup interval. This practice ensures that the spent fuel isotopics for all fuel assemblies 
contain the impact of the reactor cycle downtime when interpolation on burnup is performed. The ratio of uptime to downtime for each operating cycle was used to determine the downtime for each burnup interval. Average values for specific power were computed from the fuel group average burnups and the total uptime for the cycle. The average soluble boron concentrations were based on boron letdown curves for each operating cycle. Isotopics for assembly-specific burnups may then be obtained via interpolation between calculated isotopics at the end of each burnup interval (prior to downtime). This approach is illustrated in Fig. 2. The top portion of the picture shows the "actual" burnup histories for two hypothetical assemblies in a fuel group. Note that in this example the number of cycles and downtimes are the same, but that burnup in each assembly is different within each cycle. The lower portion of the figure demonstrates how the burnup of each assembly is represented in a SAS2H depletion, using a single calculation to represent the entire fuel group. Each cycle is broken down into multiple burnup intervals, each followed by a downtime (for the first two cycles). The final cycle is calculated with a sufficient number of burnup intervals to exceed the maximum burnup (31 MWd/MTU in Assembly A of Fig. 2 by $20 \%$. The isotopics are then available at fixed time intervals, from which interpolation can be performed for assembly specific burnups. Note that the burnup in each of the first two cycles is selected so as to represent average cycle burnups for the group. Any downtime immediately before the reactor critical conditions was not included in the SAS2H depletion, but it was explicitly modeled as described in Sect. 2.3.

As discussed earlier, group-weighted cross sections are calculated as a function of burnup within the SAS2H sequence using flux weighting performed by XSDRNPM for each specified burnup step. Cross sections are updated for a default set of isotopes built into the SAS2H sequence, plus any additional nuclides specified by the user. Table 1 shows the default set plus 44 additional actinides and fission products specified for reactor depletion cases. Also included is oxygen, which is present in significant quantities in $\mathrm{UO}_{2}$ fuel. These nuclides represent a combination of the most important nuclides for burnup credit calculations and for reactor physics calculations. The selection of burnup credit nuclides is based on availability of experimentally measured isotopic concentrations and on sensitivity studies performed for a large number of nuclides under various spent fuel transportation/storage conditions, as described in ref. 12. The reactor physics nuclides are additional isotopes which are not important in a transportation sense, but have been determined to be important for depletion, decay, and criticality calculations under reactor operating conditions (e.g., ${ }^{135} \mathrm{Xe}$ builds in rapidly during reactor operation, but decays away with a 9.1-h half-life, and is therefore unimportant in 5-year cooled spent fuel). These nuclides were identified in earlier work 10,13

Any additional cross sections required for depletion calculations are obtained from the more than 1000 nuclides available within the ORIGEN-S 1-group LWR library and are adjusted with burnup using the ORIGEN-S spectral parameters (THERM, RES, and FAST 9 calculated using fluxes calculated by XSDRNPM. The ORIGEN-S 1-group LWR library available in SCALE-4 has been updated to use cross sections from the SCALE-4 27-group burnup library for all 193 nuclides in that library, by extracting 1-group cross sections from the output of a low-burnup LWR-type fuel model using all burnup library nuclides as input.

Note that ORIGEN-S tracks all decay chains, and does not account for the loss of volatile isotopes; however, this is not felt to have a significant effect on isotopic calculations. 
ORNL-DWG 94-12310

\begin{tabular}{|c|c|c|c|c|c|}
\hline $\begin{array}{c}\text { Assembly A } \\
3 \text { cycles, } 31 \text { GWd/MTU }\end{array}$ & $\begin{array}{c}\text { Cycle } 1 \\
11 \text { GWdMTU }\end{array}$ & \begin{tabular}{|l}
100 day \\
downtime
\end{tabular} & $\begin{array}{c}\text { Cycle } 2 \\
9 \text { GWdMTU }\end{array}$ & \begin{tabular}{|l|}
120 day \\
downtime
\end{tabular} & $\begin{array}{c}\text { Cycle } 3 \\
11 \text { GWdMTU }\end{array}$ \\
\hline $\begin{array}{c}\text { Assembly B } \\
3 \text { cycles, } 29 \text { GW } 1 \text { MTU }\end{array}$ & $\begin{array}{c}\text { Cycle } 1 \\
9 \mathrm{GWd} / \mathrm{MTU}\end{array}$ & downtime & $\begin{array}{c}\text { Cycle } 2 \\
11 \text { GWd/MTU }\end{array}$ & \begin{tabular}{|l|}
120 day \\
downtime
\end{tabular} & $\begin{array}{c}\text { Cycie } 3 \\
9 \text { GWd/MTU }\end{array}$ \\
\hline
\end{tabular}

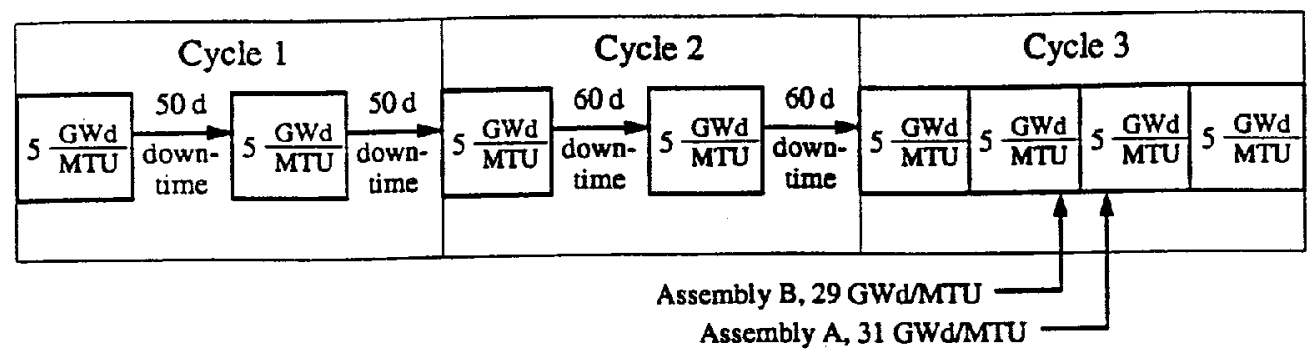

Fig. 2. SAS2H burnup model of assemblies within a fuel group. 
Table 1. Nuclides updated by SAS2H

\begin{tabular}{lllll}
\hline${ }^{234} \mathrm{U}^{a}$ & ${ }^{243} \mathrm{Am}^{a}$ & ${ }^{94} \mathrm{Nb}$ & ${ }^{132} \mathrm{Xe}$ & ${ }^{145} \mathrm{Nd}$ \\
${ }^{235} \mathrm{U}^{a}$ & ${ }^{242} \mathrm{Cm}^{a}$ & ${ }^{16} \mathrm{O}^{b}$ & ${ }^{135} \mathrm{Xe}^{a}$ & ${ }^{147} \mathrm{Nd}$ \\
${ }^{236} \mathrm{U}^{a}$ & ${ }^{243} \mathrm{Cm}^{a}$ & ${ }^{99} \mathrm{Tc}$ & ${ }^{136} \mathrm{Xe}^{147} \mathrm{Pm}$ \\
${ }^{238} \mathrm{U}^{a}$ & ${ }^{244} \mathrm{Cm}^{a}$ & ${ }^{101} \mathrm{Ru}$ & ${ }^{133} \mathrm{Cs}^{a}$ & ${ }^{148} \mathrm{Pm}$ \\
${ }^{237} \mathrm{~Np}^{a}$ & ${ }^{83} \mathrm{Kr}$ & ${ }^{106} \mathrm{Ru}$ & ${ }^{134} \mathrm{Cs}$ & ${ }^{147} \mathrm{Sm}$ \\
${ }^{238} \mathrm{Pu}^{a}$ & ${ }^{85} \mathrm{Kr}$ & ${ }^{103} \mathrm{Rh}$ & ${ }^{135} \mathrm{Cs}$ & ${ }^{149} \mathrm{Sm}$ \\
${ }^{239} \mathrm{Pu}^{a}$ & ${ }^{90} \mathrm{Sr}$ & ${ }^{105} \mathrm{Rh}$ & ${ }^{137} \mathrm{Cs}$ & ${ }^{150} \mathrm{Sm}$ \\
${ }^{240} \mathrm{Pu}^{a}$ & ${ }^{89} \mathrm{Y}$ & ${ }^{105} \mathrm{Pd}$ & ${ }^{136} \mathrm{Ba}$ & ${ }^{151} \mathrm{Sm}$ \\
${ }^{241} \mathrm{Pu}^{a}$ & ${ }^{95} \mathrm{Mo}$ & ${ }^{108} \mathrm{Pd}$ & ${ }^{139} \mathrm{La}$ & ${ }^{152} \mathrm{Sm}$ \\
${ }^{242} \mathrm{Pu}^{a}$ & ${ }^{93} \mathrm{Zr}$ & ${ }^{109} \mathrm{Ag}$ & ${ }^{144} \mathrm{Ce}$ & ${ }^{153} \mathrm{Eu}$ \\
${ }^{241} \mathrm{Am}^{a}$ & ${ }^{94} \mathrm{Zr}$ & ${ }^{124} \mathrm{Sb}$ & ${ }^{141} \mathrm{Pr}$ & ${ }^{154} \mathrm{Eu}$ \\
${ }^{242 m} \mathrm{Am}^{a}$ & ${ }^{95} \mathrm{Zr}$ & ${ }^{131} \mathrm{Xe}$ & ${ }^{143} \mathrm{Pr}$ & ${ }^{155} \mathrm{Eu}$ \\
& & & ${ }^{143} \mathrm{Nd}$ & ${ }^{155} \mathrm{Gd}$ \\
\hline
\end{tabular}

${ }^{a}$ Automatically updated by SAS2H.

${ }^{b}$ Not an actinide or fission product, but present in $\mathrm{UO}_{2}$ fuel.

\subsection{NUCLIDE CONCENTRATIONS FOR REACTOR CRITICALITY CALCULATIONS}

As has been indicated in previous sections, the isotopic content may be determined for each assembly or cross-section set by interpolating between burnups for which SAS2H/ ORIGEN-S depletion calculations have been performed, based on the final burnup of the fuel. The nuclide concentrations output at this point then represent the composition prior to shutdown or discharge. For a criticality condition obtained after the shutdown of the last cycle, it is necessary to perform decay calculations to account for the change in composition due to radioactive decay during the downtime prior to criticality.

The actual number densities used in the criticality calculations are derived from the SAS2H calculation for a given fuel batch using a newly developed interface module, SAS2H Nuclide Inventories for KENO Runs (SNIKR). This module was developed to enable the user to interpolate number densities from a SAS2H calculation as a function of burnup and to perform the necessary decay calculations to model cooling time for use in spent fuel critical calculations. SNIKR has not been incorporated into SCALE at this time. Thus, input descriptions and code listings have been included in Appendix C.

The current version of SNIKR has been written to be executed as a sequence of computational routines. In the first phase, SNIKR1, burnup-dependent nuclide inventories are read from a dataset produced from a SAS2H calculation. SNIKR1 uses a Lagrangian interpolation scheme to calculate nuclide concentrations for a specified burnup. In the Lagrangian interpolation scheme, a polynomial of degree one less than the number of data points to be fit is used to represent the number density for each nuclide as a function of burnup. Comparisons have been made against results using nuclide concentrations calculated directly from SAS2H for a specified burnup to examine the 
effect of the interpolation procedure on pin-cell $\mathrm{k}_{\infty}$ (i.e., 1-D infinite-lattice calculation) values. The results of these comparisons indicated agreement to within $0.1 \% \Delta \mathrm{k} / \mathrm{k}$ in the $\mathrm{k}_{\infty}$ values calculated using isotopics derived from the two methods.

SNIKR1 then sets up the input needed to decay these burnup-specific isotopics to the requested cooling time using the ORIGEN-S point-depletion code. The second phase of SNIKR executes the ORIGEN-S module in the SCALE code system. Phase 3, SNIKR3, reads the number densities produced by ORIGEN-S for the requested cooling time and extracts the nuclides to be used in the depleted fuel for the burnup credit criticality analysis. Number densities for these nuclides are then written to output files in the SCALE standard composition input format and the KENO V.a mixing table data format for use in CSASN and KENO V.a calculations, respectively. Typically, the term "SNIKR" is used to refer to the three-step sequence of calculations described above.

SNIKR extracts concentrations for the set of nuclides specified by the user. The set of nuclides selected for the reactor critical benchmark calculations consists of the 48 nuclides listed in Table 2. These nuclides are a subset of those in Table 1, with the exception of ${ }^{103} \mathrm{Ru},{ }^{135} \mathrm{I},{ }^{148} \mathrm{Nd}$, and

${ }^{149} \mathrm{Pm}$. The cross sections of these four nuclides are small enough or change slowly enough with burnup that omitting them from the cross-section update in SAS2H has a negligible effect and are therefore not needed in the SAS2H calculation. In addition to the 25 nuclides selected for use in burnup credit analysis in ref. 4, the list in Table 2 includes the other nuclides included in an earlier burnup credit feasibility study ${ }^{1}$ together with nuclides modeled explicitly in the burnup credit work of refs. 10 and 13.

\subsection{CROSS-SECTION PROCESSING BY CROSS-SECTION SET}

The CSASN ${ }^{6}$ sequence of the SCALE system is used to compute problem-dependent fuel pin cross sections based on the isotopic content and geometry of a lattice fuel cell. Based on a 1-D fuel pin model, CSASN invokes BONAMI- $\mathrm{S}^{14}$ to perform resonance shielding calculations using Bondarenko factors, followed by NITAWL-I 15 calculations to perform resolved resonance range cross-section processing using the Nordheim Integral Treatment.

CSASN cross-section processing is applied only to cross-section-set-averaged nuclide concentrations. As discussed earlier in Sect. 2.1, effective cross sections are not strongly coupled to burnup; hence it is sufficient to compute cross sections for the average burnup of a cross-section set, provided the range of burnups in the cross-section set is not too large ( $<2 \mathrm{GWd} / \mathrm{MTU})$. Nuclide concentrations for use in the CSASN calculation are provided in the SCALE standard composition format in the output from the SNIKR cross-section set calculations.

Because fission-product nuclides represent only a small fraction of the total number density of the fuel, fission-product cross sections are relatively insensitive to the varying isotopic content and need only be calculated for one cross-section set. This situation is also true of many fuel activation products and minor actinides; however, cross sections for seven actinides are known to have a more significant burnup dependence. These isotopes, referred to as the "seven burnupsensitive actinides," are ${ }^{234} \mathrm{U},{ }^{235} \mathrm{U},{ }^{236} \mathrm{U},{ }^{238} \mathrm{U},{ }^{239} \mathrm{Pu},{ }^{240} \mathrm{Pu}$, and ${ }^{241} \mathrm{Pu}$. CSASN cross-section set fuel pin models include the appropriate SNIKR-computed concentrations for each of these isotopes; the remaining nuclides are included only in the highest burnup cross-section set. The highest burnup is chosen because it will result in the lowest resonance absorption, and therefore results in a higher and more conservative $\mathrm{k}_{\mathrm{eff}}$; however, the effect is extremely small $(<0.1 \% \Delta \mathrm{k} / \mathrm{k})$. 
Table 2. Set of fuel nuclides used in KENO V.a calculations

\begin{tabular}{ccc}
\hline${ }^{234} \mathrm{U}^{a}$ & ${ }^{83} \mathrm{Kr}^{d}$ & ${ }^{141} \mathrm{Pr}^{b}$ \\
${ }^{235} \mathrm{U}^{a}$ & ${ }^{23} \mathrm{Zr}^{b}$ & ${ }^{143} \mathrm{Nd}^{a}$ \\
${ }^{23} \mathrm{U}^{a}$ & ${ }^{25} \mathrm{Mo}^{a}$ & ${ }^{145} \mathrm{Nd}^{a}$ \\
${ }^{238} \mathrm{U}^{a}$ & ${ }^{99} \mathrm{Tc}^{a}$ & ${ }^{147} \mathrm{Nd}^{c}$ \\
${ }^{237} \mathrm{~Np}^{b}$ & ${ }^{101} \mathrm{Ru}^{b}$ & ${ }^{148} \mathrm{Nd}^{c}$ \\
${ }^{238} \mathrm{Pu}^{a}$ & ${ }^{103} \mathrm{Ru}^{c}$ & ${ }^{147} \mathrm{Pm}^{b}$ \\
${ }^{239} \mathrm{Pu}^{a}$ & ${ }^{103} \mathrm{Rh}^{a}$ & ${ }^{148} \mathrm{Pm}^{c}$ \\
${ }^{240} \mathrm{Pu}^{a}$ & ${ }^{105} \mathrm{Rh}^{c}$ & ${ }^{149} \mathrm{Pm}^{c}$ \\
${ }^{241} \mathrm{Pu}^{a}$ & ${ }^{105} \mathrm{Pd}^{b}$ & ${ }^{147} \mathrm{Sm}^{a}$ \\
${ }^{242} \mathrm{Pu}^{a}$ & ${ }^{108} \mathrm{Pd}^{b}$ & ${ }^{149} \mathrm{Sm}^{a}$ \\
${ }^{241} \mathrm{Am}^{a}$ & ${ }^{109} \mathrm{Ag}^{b}$ & ${ }^{150} \mathrm{Sm}^{a}$ \\
${ }^{243} \mathrm{Am}^{b}$ & ${ }^{135} \mathrm{I}^{c}$ & ${ }^{151} \mathrm{Sm}^{a}$ \\
${ }^{244} \mathrm{Cm}^{b}$ & ${ }^{131} \mathrm{Xe}^{d}$ & ${ }^{152} \mathrm{Sm}^{a}$ \\
$\mathrm{O}^{a}$ & ${ }^{135} \mathrm{Xe}^{c}$ & ${ }^{153} \mathrm{Eu}^{a}$ \\
& ${ }^{133} \mathrm{Cs}^{a}$ & ${ }^{154} \mathrm{Eu}^{b}$ \\
& ${ }^{134} \mathrm{Cs}^{d}$ & ${ }^{155} \mathrm{Eu}^{b}$ \\
\hline
\end{tabular}

${ }^{a}$ The 25 nuclides to be used in burnup credit analysis (ref. 4).

${ }^{b}$ Additional burnup credit nuclides from ref. 1 .

${ }^{c}$ Additional reactor physics nuclides from Virginia Power's PDQ calculations (ref. 10).

${ }^{d}$ Additional reactor physics nuclides from Yankee Atomic's

CASMO-3/SIMULATE-3 calculations (ref. 13).

Once cross sections are computed for each cross-section set, the SCALE utility module WAX 16 s used to combine all CSASN cross-section set working libraries into a single working library for subsequent use by KENO V.a. All cross sections from the highest burnup cross-section set (containing all fission and activation isotopes) are copied into the combined library. For each of the remaining cross-section set libraries, only the seven burnup-dependent actinides are copied. In addition, for each of the seven burnup-dependent actinides in each cross-section set, the cross-section ID number is modified by prefixing the cross-section set number to the cross-section ID so that the KENO V.a core model can reference the appropriate cross section for each cross-section set. The cross sections with modified ID numbers are then copied into the combined library.

\subsection{PREPARATION OF THE KENO V.a CORE MODEL}

The geometry of the core model is based on the technical specifications of the core geometry; the detailed mechanics of the geometry model are discussed later. Using one-eighth-core symmetry, it is possible to build a full-core model using a relatively small number of unique assemblies. For each assembly type, nuclide concentrations are obtained from assembly-specific SNIKR output in 
KENO V.a mixing table format; thus there are unique mixture data for each assembly type in the model. Within each set of mixing table data, the nuclide ID number of each of the seven burnupdependent actinides is prefixed by the cross-section set number that represents that assembly (this step can be done automatically by SNIKR) so that the effective cross sections computed for the corresponding cross-section set are utilized. These cross sections are located in the working library, prepared as described in the previous subsection. 


\section{PREPARATION OF THE SEQUOYAH 2 CYCLE 3 CORE MODEL}

The previous section has given an overview of the technical procedure used in setting up the Sequoyah 2 Cycle 3 reactor critical calculations in order to provide a broad overview of the entire process before concentrating on the details. This section describes the Sequoyah 2 Cycle 3 core, then details the specifics of each step used to set up a model for this core, based on the geometry, contents, and operating history of the core up to the restart at the middle of the third cycle. Rather than follow the five steps used previously to outline the procedure, this section will describe each distinct aspect of the process, as illustrated by the individual boxes in Fig. 1.

Discussion of the KENO V.a criticality calculation results will be provided in Sect. 4 of this report.

\subsection{CORE DESCRIPTION}

Data describing the Sequoyah Unit 2 core and assembly data for cycles 1-3 were obtained from several sources, including cycle operations data, the plant Final Safety Analysis Report, and data generated by TVA calculations. Because much of these data are not readily available as public information, all data required to perform this analysis are included in Appendix A and in the following description.

The Sequoyah 2 Cycle 3 core consisted of 193 Westinghouse fuel assemblies, each comprised of a $17 \times 17$ lattice containing 264 fuel rods, 24 control rod guide tubes, and one instrument tube. The core configuration is shown in Fig. 3, where each square represents an assembly position. Atpower reactivity control is maintained using four control banks and two shutdown banks of full-length Ag-In-Cd control rod clusters, 44 BPR clusters containing a total of 656 BPRs, and soluble boron. Within each assembly, the lattice positions of guide tubes and/or BPRs are located as illustrated in Fig. 4. The loading of the BPR clusters in Cycle 3 is shown in Fig. 5.

The critical conditions modeled in this report are based on HZP and HFP conditions at BOC-3 and HFP conditions at the MOC-3 restart. The MOC restart critical configuration of Sequoyah Unit 2 Cycle 3, after a 2.73-year downtime, was selected as a benchmark critical for use in burnup credit validation because there was a significantly long downtime prior to restart and no fresh fuel was loaded into the reactor prior to restart. The BOC startup configurations for Cycle 3 at HZP and HFP were utilized as additional benchmarks to provide a check for consistency in the calculated results for different burnups and downtimes. The downtime between Cycles 2 and 3 was 154 days (0.42 year).

The HZP and HFP criticals at BOC and the HFP critical at MOC were selected in part because the control rod position for each is at or near all rods out (ARO). The ARO condition is advantageous because it reduces the complexity of the calculational model. Partially inserted control rods would require additional axial regions in the KENO V.a model. The control rods consist of very strong localized neutron absorber materials (silver, indium, cadmium). The advantages of the HZP case are that the temperature is uniform and there is no xenon. In the HFP cases the temperature and xenon distributions are not uniform throughout the core, but are a function of the relative power produced by each fuel assembly. Since this information was not readily available, uniform temperature and xenon distributions were assumed in the HFP KENO V.a models. The critical conditions at BOC-3 and MOC-3 are given in Table 3. 
(B) Burnable Poison Rod Cluster

- Control Rod Cluster

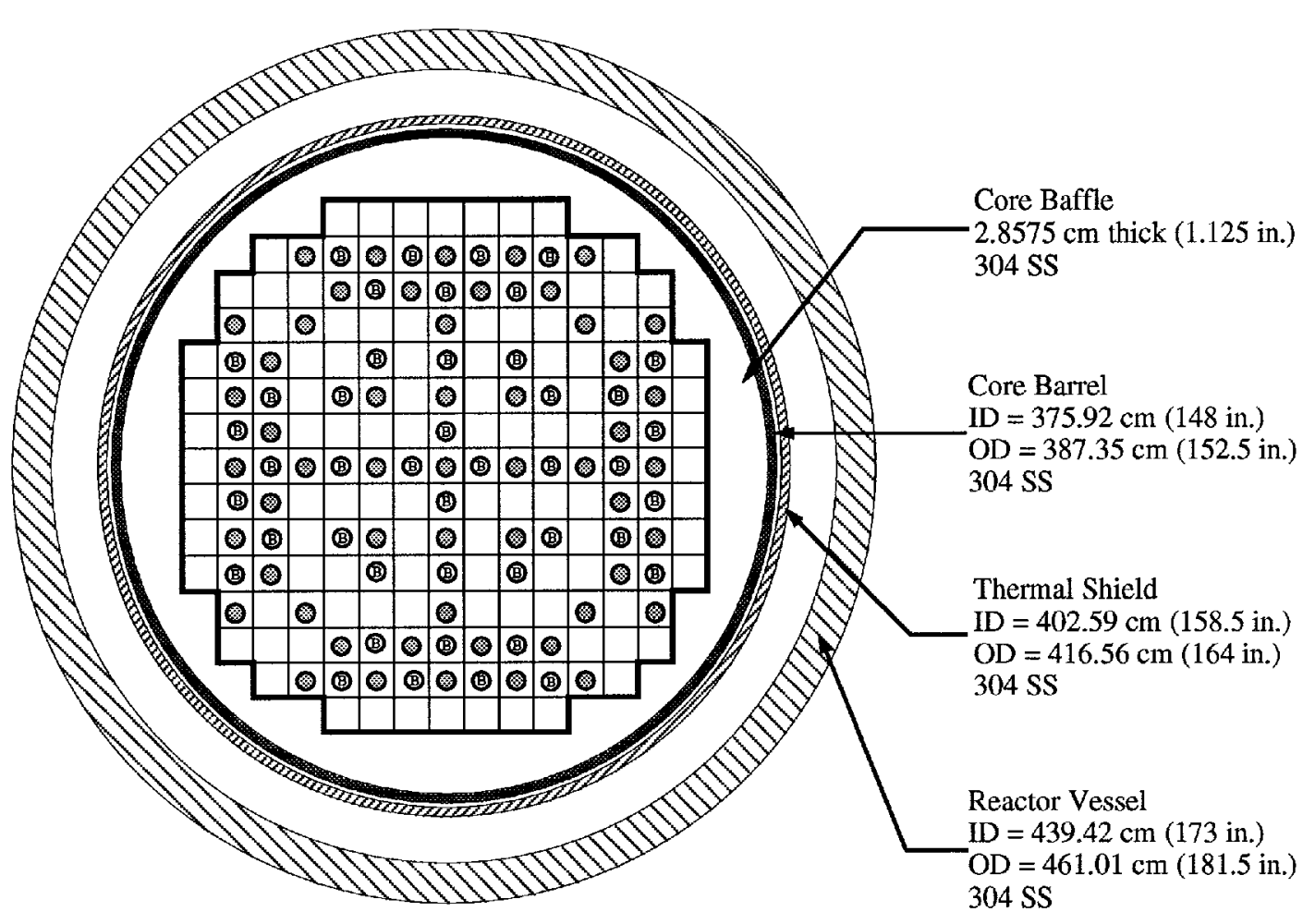

Fig. 3. Sequoyah Unit 2 Cycle 3 core configuration. 

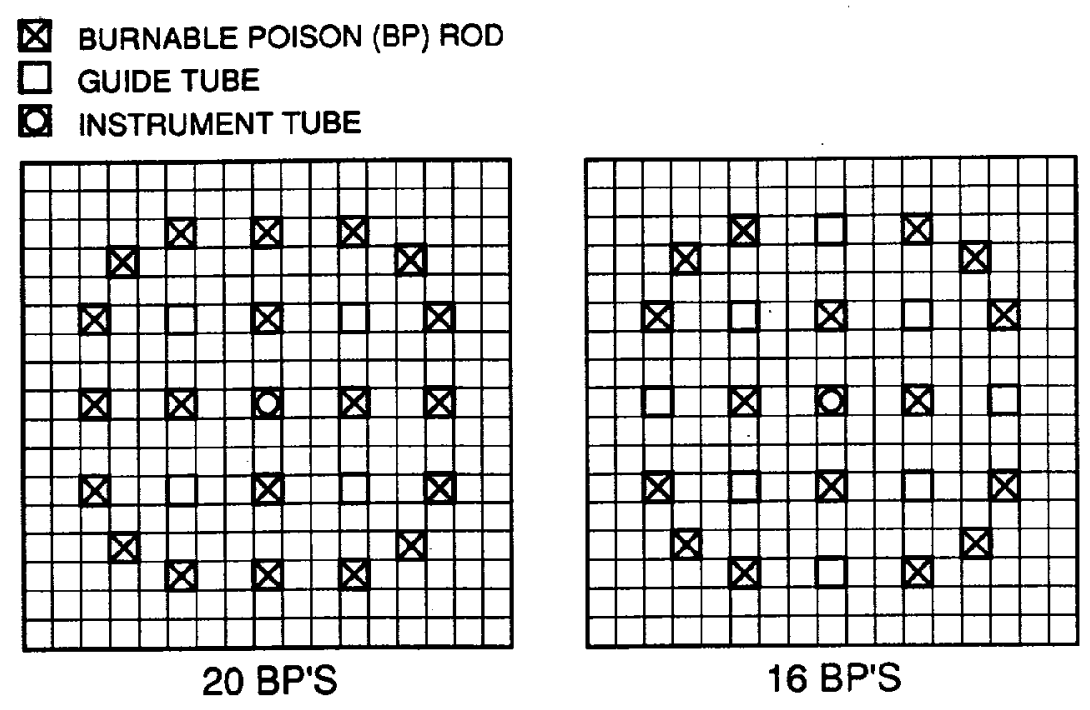

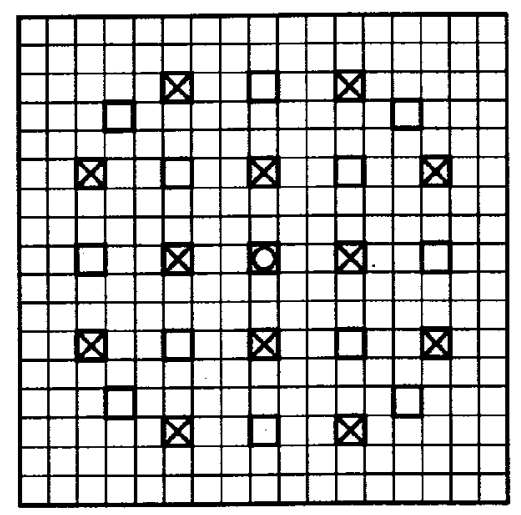

12 BP'S

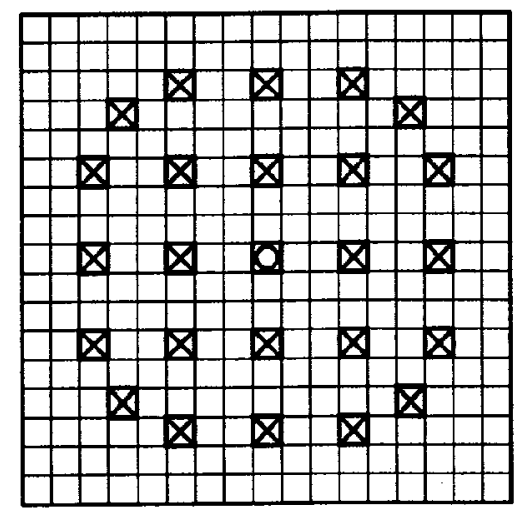

24 BP'S

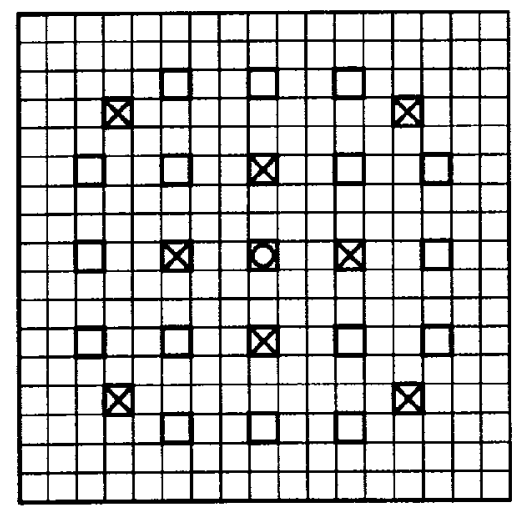

8 BP'S

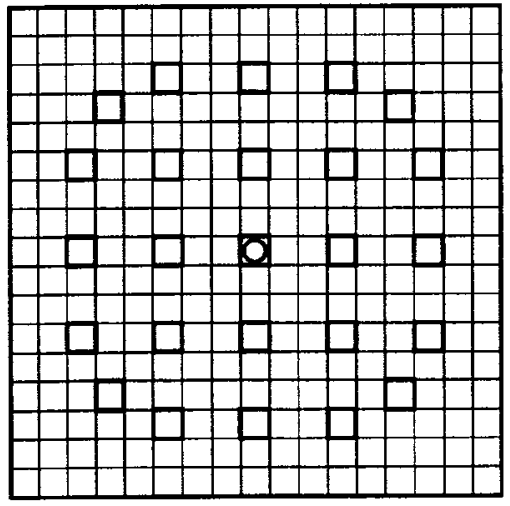

NO BP'S

Fig. 4. Fuel assembly lattice arrangements in Sequoyah Unit 2 Cycle 3. 
ORNL-DWG $92 \mathrm{M}-8947$

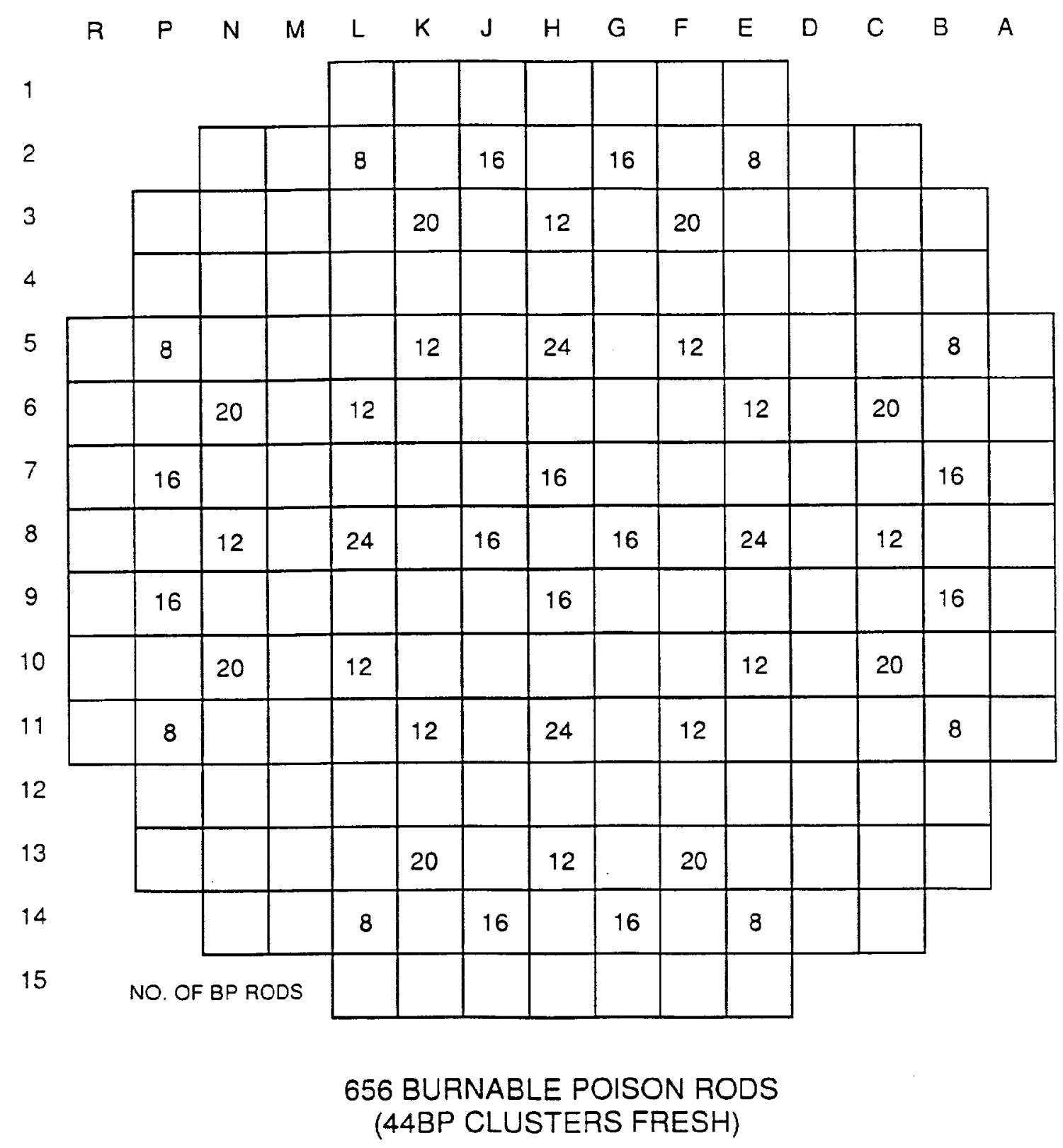

Fig. 5. Sequoyah Unit 2 Cycle 3 burnable poison loading configuration. 
Table 3. Sequoyah Unit 2 Cycle 3 measured critical conditions at BOC and MOC

\begin{tabular}{cccccc}
$\begin{array}{c}\text { Time in } \\
\text { cycle }\end{array}$ & $\begin{array}{c}\text { Cycle burnup } \\
(\mathrm{MWd} / \mathrm{MTU})\end{array}$ & Power & $\begin{array}{c}\text { Control Bank } \mathrm{D}^{a} \\
\text { position } \\
(\mathrm{cm} \text { inserted })\end{array}$ & $\begin{array}{c}\text { Critical boron } \\
(\mathrm{ppm})\end{array}$ & $\begin{array}{c}\text { Average temp. } \\
\left({ }^{\circ} \mathrm{F}\right)\end{array}$ \\
\hline BOC & 0 & HZP & 0.0 & 1685 & 547 \\
BOC & 150 & HFP & 0.0 & 1150 & 582 \\
MOC & 8250 & HFP & 1.6 & 475 & 582 \\
\hline
\end{tabular}

${ }^{\mathrm{a} C}$ Control Banks A through C are withdrawn.

For BOC-3, five fuel batches were present in the core. Fuel batches 2 and 3 were manufactured with 2.6 and $3.1 \mathrm{wt} \%{ }^{235} \mathrm{U}$, respectively. Both batches were loaded initially in Cycle 1. Batch 4, with an enrichment of $3.5 \mathrm{wt} \%{ }^{235} \mathrm{U}$, was initially loaded in Cycle 2. Batch 5 was split into two batches, $5 \mathrm{~A}$ and $5 \mathrm{~B}$, with initial enrichments of 3.8 and $3.6 \mathrm{wt} \%{ }^{235} \mathrm{U}$, respectively. Batches 5A and 5B were loaded initially in Cycle 3. Full-core loading maps, assembly burnup data, and boron letdown curves for Cycles 1 through 3 are included in Appendix A. Table 4 provides a physical description of the significant aspects of the fuel design for all assemblies.

In order to simplify and to reduce the volume of input in the KENO V.a model, eighth-core symmetry was assumed in the isotopic input. This assumption reduces the number of unique fuel assemblies to 31 (Fig. 6). The loading pattern for Sequoyah Unit 2 Cycle 3 (Fig. A.6) is eighth-core symmetric except for fuel assembly location 31 on the core periphery in the eighth-core model (Fig. 6). Instead of a symmetric set of eight fuel assemblies from a single fuel region, two symmetric sets of four fuel assemblies from two fuel regions were loaded in those eight full-core locations. These are high-burnup assemblies in a high-neutron-leakage location and therefore have a negligible impact on the core $\mathrm{k}_{\text {eff. }}$.

The assembly burnups were averaged from Fig. A.6 for BOC and Table A.1 for MOC based on the eighth-core symmetry shown in Fig. 6. Assembly burnups listed throughout the remainder of this report are eighth-core average values.

\subsection{SAS2H FUEL GROUPS}

Assemblies of a given fuel batch are generally relocated within the core between cycles, resulting in a more evenly distributed burnup between assemblies because all fuel assemblies in a batch were loaded in the core during the same operating cycles. Because all fuel assemblies in a batch are loaded in the core during the same operating cycles, each assembly in a batch experiences the same operating (uptime/downtime) history. Thus, a starting point for the process of grouping similarcontent assemblies is to begin with fuel batches. As indicated in Fig. 1, assembly group information was used in preparation of SAS2H input for depletion calculations. For BOC-3, the Sequoyah 2 core was comprised of five fuel batches. Because BPR clusters were loaded in certain assemblies in batches $5 \mathrm{~A}$ and $5 \mathrm{~B}$, additional subdivision of these batches was necessary. Each of these two batches were divided into two fuel groups, one for fuel assemblies with BPR clusters and one for fuel 
Table 4. Sequoyah PWR Unit 2 assembly design description

\begin{tabular}{|c|c|}
\hline Parameter & Data \\
\hline \multicolumn{2}{|l|}{ Assembly general data } \\
\hline Number of assemblies & 193 \\
\hline Fresh core loading, $\mathrm{kgU}$ & 90,000 \\
\hline Designer & Westinghouse \\
\hline Lattice & $17 \times 17$ \\
\hline Coolant pressure, psia & 2250 \\
\hline Water temperature, $\mathrm{K}\left({ }^{\circ} \mathrm{F}\right)$ & $579(582)^{a}$ \\
\hline Water density, $\mathrm{g} / \mathrm{cm}^{3}$ & $0.7149^{a, b}$ \\
\hline Number of fuel rods & 264 \\
\hline Number of guide tubes & 24 \\
\hline Number of instrument tubes & 1 \\
\hline Lattice pitch, cm (in.) & $21.50364(8.466)$ \\
\hline \multicolumn{2}{|l|}{ Fuel rod data } \\
\hline Type fuel pellet & $\mathrm{UO}_{2}$ \\
\hline Pellet stack density, \% TD & $94.85^{c}$ \\
\hline Rod pitch, cm (in.) & $1.25984(0.496)$ \\
\hline Rod OD, cm (in.) & $0.94966(0.374)$ \\
\hline Rod ID, cm (in.) & $0.83566(0.329)$ \\
\hline Pellet diameter, $\mathrm{cm}$ (in.) & $0.81915(0.3225)$ \\
\hline Active fuel length, cm (in.) & $365.8(144)$ \\
\hline Effective fuel temperature, $\mathrm{K}\left({ }^{\circ} \mathrm{F}\right)$ & $901(1162)^{a}$ \\
\hline Clad temperature, $\mathrm{K}\left({ }^{\circ} \mathrm{F}\right)$ & $629(670)^{a}$ \\
\hline Clad material & Zircaloy-4 \\
\hline \multicolumn{2}{|l|}{ Guide tube data } \\
\hline Inner radius, $\mathrm{cm}(\mathrm{ID}$, in. $)$ & $0.5715(0.45)$ \\
\hline Outer radius, $\mathrm{cm}(\mathrm{OD}$, in. $)$ & $0.61214(0.482)$ \\
\hline Tube material & Zircaloy-4 \\
\hline
\end{tabular}

${ }^{a}$ Average HFP value.

${ }^{b}$ Interpolated from the water density vs pressure and temperature table in the SAS2H input guide (ref. 5).

${ }^{c}$ Based on a fuel loading of $90,000 \mathrm{kgU}$. 
ORNL-DWG 92M-8874

$\begin{array}{lllllllllllllll}R & P & N & M & L & K & J & H & G & F & E & D & C & B & A\end{array}$

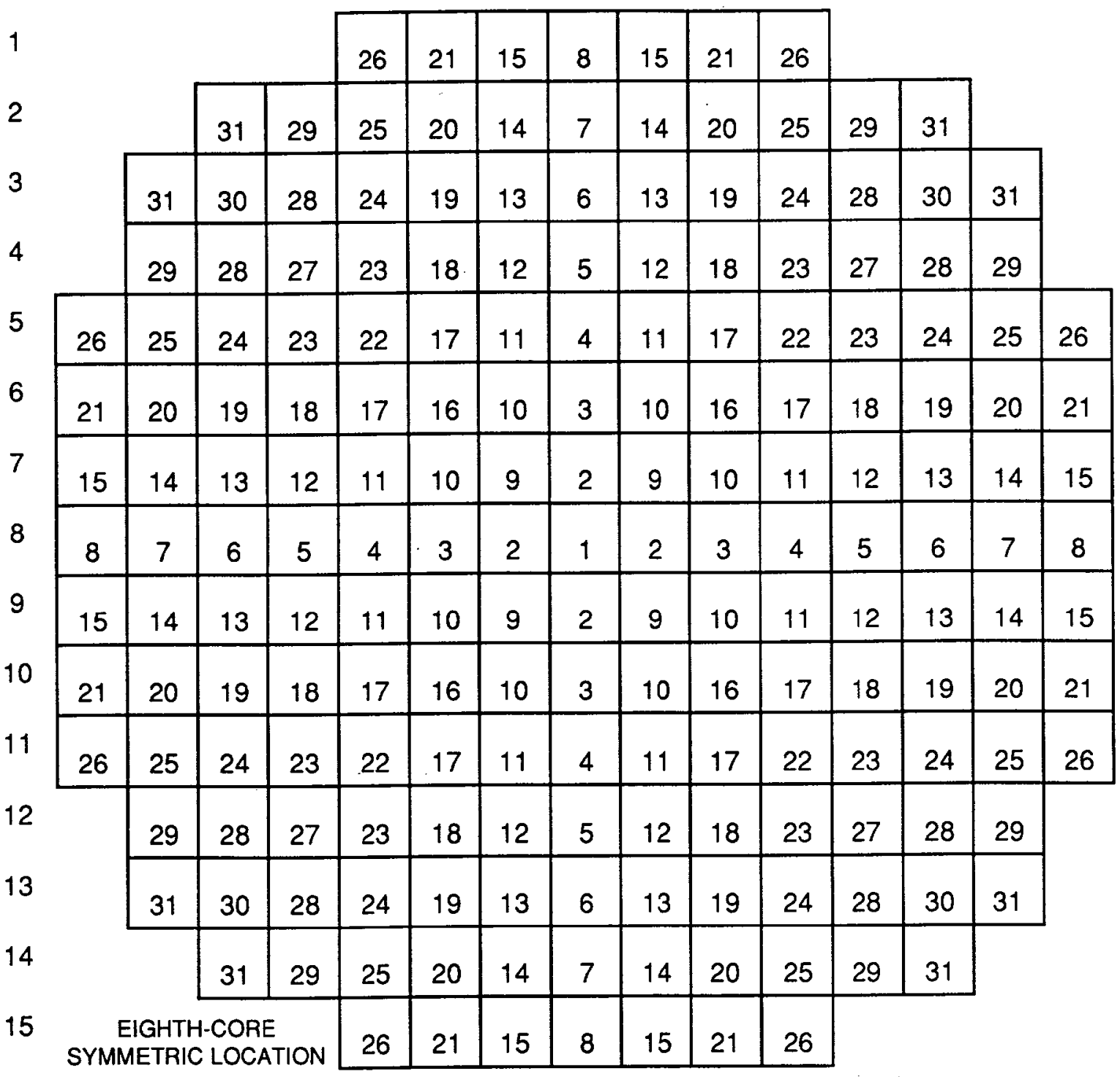

Fig. 6. Sequoyah Unit 2 eighth-core symmetric configuration. 
assemblies without BPR clusters. The differences between the 1-D fuel cell model for these two types of fuel groups are discussed in Sects. 3.2.1 and 3.2.2. Each fuel group was modeled as a single unit in a SAS2H depletion calculation over the range of burnups represented by the assemblies in the group. Table 5 provides relevant information about each fuel group.

The initial uranium content of each group was determined from the initial ${ }^{235} \mathrm{U}$ enrichment of the associated fuel batch. The following empirical relationship was used to determine relative isotopic content: ${ }^{17}$

$$
\begin{aligned}
& \mathrm{w}_{234}=0.007731\left(\mathrm{w}_{235}\right)^{1.0837}, \\
& \mathrm{w}_{236}=0.0046 \mathrm{w}_{235}, \\
& \mathrm{w}_{238}=100-\mathrm{w}_{234}-\mathrm{w}_{235}-\mathrm{w}_{236},
\end{aligned}
$$

where $\mathrm{w}$ is the weight percentage of the given uranium isotope. Using this formulation, the fresh fuel isotopics for all enrichments were computed. The results are given in Table 6.

In addition to the heavy metal fuel material, light elements are also present in the fuel assembly in the fuel clad and grid. Elements whose masses are typically found to be in excess of $0.5 \mathrm{~g} / \mathrm{kgU}$, plus Mn and Co, are shown in Table 7, along with their estimated masses. These masses are required by SAS2H. They are not used in the neutronics model but are applied in determining the $(\mathrm{n}, \gamma)$ fraction of energy per fission.

Each SAS2H calculation also requires specification of the temperature of each material for use in cross-section Doppler broadening corrections. However, since material and, therefore, thermal properties change with exposure, and because an assembly's peak temperature is a function of its linear heat rate, the average temperature in the fuel (and to a lesser extent the average clad temperature) will change with burnup and location. The only thermal data available were average fuel, clad, and moderator temperatures as given in Table 4.

\subsubsection{SAS2H Fuel Cell Without BPRs}

The SAS2H fuel cell model input for the five fuel groups without BPR clusters was relatively simple. Requirements included the dimensions of the fuel rod, clad, control-rod guide tube, and lattice pitch and the number of lattice positions in each fuel assembly that are not occupied by fuel rods (i.e., control rod guide tubes or instrumentation tubes). From this basic information included in Table 4, SAS2H constructed a 1-D effective assembly model consisting of a guide tube surrounded by a fuel/moderator region with a volume proportional to the fuel/guide tube volume ratio in the assembly. Cross sections for the fuel region are obtained from a pin cell calculation. More details of this default SAS2H assembly model can be found in ref. 5.

\subsubsection{SAS2H Fuel Cell With BPRs}

For the two fuel groups with BPR clusters (fuel groups 5 and 7), an effective fuel cell was derived to incorporate the BPR cell together with the guide tube cell in SAS2H. In the effective cell, the densities of the isotopes or elements remained unchanged from their actual densities, but rod diameters of the glass and stainless steel in the BPRs were reduced to account for their absence in the 
Table 5. Fuel group data for MOC-3

\begin{tabular}{cccccccc}
\hline $\begin{array}{c}\text { SAS2H } \\
\text { fuel } \\
\text { group }\end{array}$ & $\begin{array}{c}\text { Sequoyah-2 } \\
\text { fuel } \\
\text { batch }\end{array}$ & $\begin{array}{c}\text { Contain } \\
\text { BPRs in } \\
\text { Cycle 3 }\end{array}$ & $\begin{array}{c}\text { Cycles } \\
\text { in-core }\end{array}$ & $\begin{array}{c}\text { Av. B/U, } \\
\text { MWd/MTU }\end{array}$ & $\begin{array}{c}\text { Min. B/U, } \\
\text { MWd/MTU }\end{array}$ & $\begin{array}{c}\text { Max. B/U } \\
\text { MWd/MTU }\end{array}$ & $\begin{array}{c}\text { Enrichment, } \\
\text { wt \% }\end{array}$ \\
\hline & 2 & No & $1,2,3$ & 30,172 & 30,812 & 31,622 & 2.6 \\
1 & 3 & No & $1,2,3$ & 30,343 & 27,263 & 34,555 & 3.1 \\
2 & 4 & No & 2,3 & 19,780 & 13,362 & 23,784 & 3.5 \\
3 & 5A & No & 3 & 7,742 & 7,306 & 8,177 & 3.8 \\
4 & 5A & Yes & 3 & 9,487 & 9,019 & 9,935 & 3.8 \\
5 & 5B & No & 3 & 7,713 & 7,366 & 8,060 & 3.6 \\
6 & 5B & Yes & 3 & 9,977 & 9,755 & 10,119 & 3.6 \\
7 & & & & & & & \\
\hline
\end{tabular}

Table 6. Initial uranium isotopic content of fresh fuel

\begin{tabular}{ccccc} 
& \multicolumn{4}{c}{ Initial U isotopes, wt \% } \\
\cline { 2 - 5 } Fuel & ${ }^{234} \mathrm{U}$ & ${ }^{235} \mathrm{U}$ & ${ }^{236} \mathrm{U}$ & ${ }^{238} \mathrm{U}$ \\
\hline 2 & 0.022 & 2.6 & 0.012 & 97.366 \\
3 & 0.026 & 3.1 & 0.014 & 96.860 \\
4 & 0.030 & 3.5 & 0.016 & 96.454 \\
$5 \mathrm{~A}$ & 0.033 & 3.8 & 0.017 & 96.150 \\
$5 \mathrm{~B}$ & 0.031 & 3.6 & 0.017 & 96.352 \\
\hline
\end{tabular}

$\underline{\text { Table 7. Light-element masses used in SAS2H calculations }}$

\begin{tabular}{cc}
\hline Element & Weight, g/kgU \\
\hline $\mathrm{O}$ & 135.0 \\
$\mathrm{Cr}$ & 5.9 \\
$\mathrm{Mn}$ & 0.33 \\
$\mathrm{Fe}$ & 12.9 \\
$\mathrm{Co}$ & 0.075 \\
$\mathrm{Ni}$ & 9.9 \\
$\mathrm{Zr}$ & 221.0 \\
$\mathrm{Nb}$ & 0.71 \\
$\mathrm{Sn}$ & 3.6 \\
\hline
\end{tabular}


guide tube positions. The method of deriving the effective cell was such that the various material total masses were conserved.

The composition of the borosilicate glass as modeled is listed in Table 8 using data for typical borosilicate glass $\frac{18}{18}$ These data and atomic weights of the elements and isotopic abundance values 19 were applied in deriving the atomic densities of the borosilicate glass in Table 9. The glass density, $2.23 \mathrm{~g} / \mathrm{cm}^{3}$, was also obtained from ref. 18 .

The number of BPR assemblies in fuel groups 5 and 7 and the number of assemblies having specific combinations of BPRs and guide tubes are shown in Table 10. The total number of BPRs and guide tubes for each group is also given in the table. Applying these totals and the dimensions of the BPRs, guide tubes, and lattice pitch, a set of effective unit cell dimensions were computed. The radius bounding each material was calculated from the outer to inner zone boundary for each average material volume. For example, the water moderator average volume $\bar{V}_{w}$ for fuel group 5 is

$$
\bar{V}_{w}=(352)\left(V_{T}-V_{G T}-V_{B P}\right) / 576+(224)\left(V_{T}-V_{G T}\right) / 576,
$$

where

$$
\begin{aligned}
& V_{T}=\text { total cell volume }=(\text { pitch })^{2} \times(\text { length }) \\
& V_{G T}=\text { guide tube volume }(\text { same as outer tube in BPR cell }) \\
& V_{B P}=\text { BP rod total volume. }
\end{aligned}
$$

Then the inner radius of the water or the effective radius of the BP rod is

$$
R_{B P}=\sqrt{\left(V_{T}-\bar{V}_{w}-V_{G T}\right) /(\pi L)},
$$

where $L$ is the active fuel length used in computing the volumes. The guide tube dimensions remain the same because they are identical in both types of cells. Each average volume, $V_{a v e}$, within the effective BP rod is calculated from the corresponding actual BP rod dimensions (and totals for group 5 from Table 10):

$$
V_{\text {ave }}=(352 \pi L)\left(B^{2}-A^{2}\right) / 576,
$$

where

$A=$ the material's inner radius in an actual BP rod,

$B=$ the same material zone's outer radius. 
Using the prior calculation of the effective outer radius, $B_{e}$, the effective inner radius, $A_{e}$ is

$$
A_{e}=\sqrt{B_{e}^{2}-V_{a v e} /(\pi L)} .
$$

Equations (1) and (2) are repeatedly used for each material zone for the entire effective cell determination. Applying the above procedure, the effective cell mockup dimensions for fuel groups

Table 8. Borosilicate glass composition

in BPR assemblies

\begin{tabular}{lc}
\hline Compound & Weight fraction \\
\hline $\mathrm{SiO}_{2}$ & 0.805 \\
$\mathrm{~B}_{2} \mathrm{O}_{3}$ & 0.125 \\
$\mathrm{Na}_{2} \mathrm{O}$ & 0.038 \\
$\mathrm{~K}_{2} \mathrm{O}$ & 0.004 \\
$\mathrm{Al}_{2} \mathrm{O}_{3}$ & 0.022 \\
\hline
\end{tabular}

Table 9. Borosilicate glass input atom densities ${ }^{a}$

\begin{tabular}{lccc}
\hline Element & Isotope & Weight fraction & $\begin{array}{c}\text { Density, } \\
\text { [atoms/(barn·cm) }\end{array}$ \\
\hline $\mathrm{O}$ & 0.5358 & 0.04497 \\
$\mathrm{Na}$ & 0.0282 & 0.00165 \\
$\mathrm{Al}$ & 0.0116 & 0.00058 \\
$\mathrm{Si}$ & 0.3763 & 0.01799 \\
$\mathrm{~K}$ & & 0.0033 & 0.00011 \\
$\mathrm{~B}$ & & 0.03882 & \\
& & & $9.595 \mathrm{E}-4^{b}$ \\
Total & ${ }^{10} \mathrm{~B}$ & & $3.863 \mathrm{E}-3$ \\
\hline${ }^{a} \mathrm{Apply}$ & & & \\
\hline
\end{tabular}

${ }^{a}$ Applying weight fractions of compounds in Table 8 and $2.23 \mathrm{~g} / \mathrm{cm}^{3}$ glass density.

${ }^{b}$ Read as $9.595 \times 10^{-4}$. 
Table 10. Number of BPRs and guide tubes in fuel groups 5 and 7

\begin{tabular}{|c|c|c|c|c|c|c|c|}
\hline \multirow[b]{2}{*}{$\begin{array}{l}\text { Fuel } \\
\text { group }\end{array}$} & \multirow[b]{2}{*}{$\begin{array}{l}\text { Fuel } \\
\text { batch }\end{array}$} & \multirow[b]{2}{*}{$\begin{array}{l}\text { Number of } \\
\text { assemblies }\end{array}$} & \multicolumn{2}{|c|}{ Number/assembly } & \multicolumn{3}{|c|}{ Total number } \\
\hline & & & BP rods & Guide tubes & BP rods & $\begin{array}{l}\text { Guide } \\
\text { tubes }\end{array}$ & $\begin{array}{l}\text { Nonfue }^{a} \\
\text { locations }\end{array}$ \\
\hline 5 & $5 \mathrm{~A}$ & 8 & 20 & 4 & 160 & 32 & 192 \\
\hline 5 & $5 \mathrm{~A}$ & 8 & 16 & 8 & 128 & 64 & 192 \\
\hline 5 & $5 \mathrm{~A}$ & 8 & 8 & 16 & 64 & 128 & 192 \\
\hline Total & & 24 & & & 352 & 224 & 576 \\
\hline 7 & $5 \mathrm{~B}$ & 4 & 24 & 0 & 96 & 0 & 96 \\
\hline 7 & $5 \mathrm{~B}$ & 4 & 16 & 8 & 64 & 32 & 96 \\
\hline 7 & $5 \mathrm{~B}$ & 12 & 12 & 12 & 144 & 144 & 288 \\
\hline Total & & 20 & & & 304 & 176 & 480 \\
\hline
\end{tabular}

${ }^{a}$ Excluding instrument tube.

5 and 7 were computed as listed in Table 11. The densities listed in the table were used only in computing material mass for verification of data.

The total material masses of the actual BP rods plus that of the guide tubes were compared with the effective cell total masses. The data were used to verify the cell dimensions. In all cases identical weights were computed for the same materials, verifying that the effective cells conserve mass.

\subsection{SIMILAR-BURNUP SUBGROUPING FOR CROSS-SECTION SETS}

Although the assemblies of a given fuel group are identical in terms of initial composition, time in core, and operating history, there may be a relatively broad range of burnups within a fuel group. Even though effective cross sections are felt to be insensitive to minor variations in burnups, it is necessary to set a maximum range of burnups for which an average burnup is an acceptable approximation in determining cross sections. As demonstrated in Sect. 3.8, a range of no more than $2 \mathrm{GWd} / \mathrm{MTU}$ has been found to be acceptable; this value was used in subdividing fuel groups into similar-burnup cross-section sets. As shown in Fig. 1, cross-section set information is provided to SNIKR for subsequent use in setting up CSASN calculations. CSASN is used to compute effective cross sections for each cross-section set. Since cross sections had to be calculated at BOC-3 and MOC-3, fuel groups had to be subdivided into cross-section sets at both burnups.

In order to determine cross-section sets for each fuel group, the fuel assembly burnups in each group were sorted and divided into subgroups where the minimum-to-maximum burnup range was no larger than $2 \mathrm{GWd} / \mathrm{MTU}$. Eighth-core-averaged assembly burnups are given in Table 12, along with fuel batch, SAS2H fuel group, and cross-section set information. The cross-section set 
Table 11. Effective fuel cells with BPRs

\begin{tabular}{|c|c|c|c|c|c|}
\hline \multirow[b]{2}{*}{ Zone } & \multirow[b]{2}{*}{ Material } & \multirow{2}{*}{$\begin{array}{l}\text { Density, } \\
\mathrm{g} / \mathrm{cm}^{3}\end{array}$} & \multirow{2}{*}{$\begin{array}{l}\text { SAS2H } \\
\text { mixture } \\
\text { number }\end{array}$} & \multicolumn{2}{|c|}{ Radius in cell, $\mathrm{cm}$} \\
\hline & & & & Fuel group 5 & Fuel group 7 \\
\hline 1 & Air & $1.22 \mathrm{E}-3^{a}$ & 7 & 0.16728 & 0.17030 \\
\hline 2 & SS-304 & 7.92 & 5 & 0.18019 & 0.18344 \\
\hline 3 & Air & $1.22 \mathrm{E}-3$ & 7 & 0.18863 & 0.19203 \\
\hline 4 & Glass & 2.23 & 6 & 0.33358 & 0.33959 \\
\hline 5 & Air & $1.22 \mathrm{E}-3$ & 7 & 0.34152 & 0.34768 \\
\hline 6 & SS-304 & 7.92 & 5 & 0.37826 & 0.38507 \\
\hline 7 & Mod & 0.7149 & 3 & 0.57150 & 0.57150 \\
\hline 8 & $\mathrm{Zr}-4$ & 6.44 & 2 & 0.61214 & 0.61214 \\
\hline 9 & Mod & 0.7149 & 3 & 0.71079 & 0.71079 \\
\hline 10 & Fuel & 10.3682 & 500 & 2.43666 & 2.43666 \\
\hline
\end{tabular}

${ }^{a}$ Read as $1.22 \times 10^{-3}$. 
Table 12. Fuel assembly data for eighth-core geometry

\begin{tabular}{|c|c|c|c|c|c|c|}
\hline \multirow[b]{2}{*}{$\begin{array}{l}\text { Eighth-core } \\
\text { location }\end{array}$} & \multirow{2}{*}{$\begin{array}{c}\text { Sequoyah } \\
\text { fuel } \\
\text { batch } \\
\end{array}$} & \multirow[b]{2}{*}{$\begin{array}{c}\text { SAS2H } \\
\text { fuel group }\end{array}$} & \multicolumn{2}{|c|}{$\begin{array}{c}\text { Cross-section } \\
\text { set }\end{array}$} & \multicolumn{2}{|c|}{$\begin{array}{c}\text { Average burnup } \\
\text { (MWd/MTU) }\end{array}$} \\
\hline & & & $\mathrm{BOC}$ & MOC & $\mathrm{BOC}$ & MOC \\
\hline 1 & 3 & 2 & 2 & 2 & 21,182 & 29,434 \\
\hline 2 & $5 B$ & 7 & 11 & 11 & 0 & 10,102 \\
\hline 3 & 4 & 3 & 7 & 7 & 13,137 & 23,062 \\
\hline 4 & $5 B$ & 7 & 11 & 11 & 0 & 9,787 \\
\hline 5 & 2 & 1 & 1 & 1 & 23,637 & 30,812 \\
\hline 6 & $5 B$ & 7 & 11 & 11 & 0 & 9,755 \\
\hline 7 & 3 & 2 & 2 & 3 & 22,226 & 30,246 \\
\hline 8 & $5 B$ & 6 & 10 & 10 & 0 & 8,060 \\
\hline 9 & 3 & 2 & 4 & 4 & 26,859 & 34,555 \\
\hline 10 & 4 & 3 & 7 & 7 & 13,298 & 22,810 \\
\hline 11 & 4 & 3 & 7 & 7 & 14,229 & 23,784 \\
\hline 12 & 4 & 3 & 6 & 6 & 11,846 & 21,023 \\
\hline 13 & 3 & 2 & 2 & 2 & 21,645 & 29,506 \\
\hline 14 & $5 \mathrm{~A}$ & 5 & 9 & 9 & 0 & 9,935 \\
\hline 15 & $5 \mathrm{~A}$ & 4 & 8 & 8 & 0 & 8,177 \\
\hline 16 & 3 & 2 & 3 & 3 & 23,043 & 31,051 \\
\hline 17 & $5 B$ & 7 & 11 & 11 & 0 & 10,119 \\
\hline 18 & 3 & 2 & 3 & 3 & 23,685 & 31,312 \\
\hline 19 & $5 \mathrm{~A}$ & 5 & 9 & 9 & 0 & 9,506 \\
\hline 20 & 3 & 2 & 2 & 2 & 20,877 & 28,554 \\
\hline 21 & $5 \mathrm{~A}$ & 4 & 8 & 8 & 0 & 7,306 \\
\hline 22 & 3 & 2 & 3 & 3 & 24,587 & 32,147 \\
\hline 23 & 4 & 3 & 6 & 6 & 10,575 & 19,376 \\
\hline 24 & 4 & 3 & 7 & 7 & 14,185 & 22,943 \\
\hline 25 & $5 \mathrm{~A}$ & 5 & 9 & 9 & 0 & 9,019 \\
\hline 26 & 4 & 3 & 5 & 5 & 8,618 & 13,362 \\
\hline 27 & 2 & 1 & 1 & 1 & 25,339 & 31,622 \\
\hline 28 & 4 & 3 & 6 & 6 & 10,711 & 18,755 \\
\hline 29 & 4 & 3 & 5 & 5 & 8,550 & 14,546 \\
\hline 30 & $5 B$ & 6 & 10 & 10 & 0 & 7,366 \\
\hline 31 & 3 & 2 & 3 & 2 & 24,497 & 27,263 \\
\hline
\end{tabular}


groupings are shown in Table 13. Tables 14 and 15 show the cross-section sets at BOC and MOC, respectively, with the actual burnup ranges for assemblies within each cross-section set, along with the mean average burnup of all assemblies in each cross-section set. Note that no subgrouping was necessary for fuel groups 4 through 7; these assemblies were fresh fuel when loaded at BOC-3.

\subsection{SAS2H DEPLETION CALCULATIONS}

SAS2H depletion calculations were required for all fuel groups since all fuel assemblies loaded at the MOC-3 restart consisted of spent fuel. In the standard composition section of the SAS2H input for each fuel group, the initial uranium isotopic contents for the $\mathrm{UO}_{2}$ fuel were as given in Table 6. Although not initially present in the fuel, the additional 44 nuclides from Table 1 were included at an atom density of $1 \times 10^{-20}\left({ }^{135} \mathrm{Xe}\right.$ was specified with an initial density on the order of its equilibrium concentration, since it quickly reaches this equilibrium concentration shortly after startup), indicating to SAS2H that cross sections for these isotopes should be updated at the end of each burn cycle, as discussed previously in Sect. 2.2. The remainder of the fuel pin cell was described as Zircaloy clad in water, with temperature and geometry data as specified in Table 4. The active fuel length was specified as $784.35 \mathrm{~cm} / \mathrm{MTU}$ based on the actual fuel length of $365.76 \mathrm{~cm}$ divided by the total weight of heavy metal of $0.46632 \mathrm{MTU}$; this modification gives results in units of burnup per MTU rather than burnup per assembly. Since SAS2H uses a 1-D assembly cell model, the fuel length is arbitrary and may be used as a conversion factor.

Table 16 gives the power history data used for each SAS2H fuel group. Note that a constant burnup per interval was used for each fuel group; this constant spacing is required by SNIKR when interpolating from SAS2H/ORIGEN output. Shorter burnup intervals were used for the fresh fuel loaded in Cycle 3 (batches 5A and 5B) in order to have a sufficient number of data points for SNIKR to interpolate. The number of intervals for each group was chosen so that the maximum assembly burnup was exceeded by at least $20 \%$. The average specific power for each fuel group was calculated by dividing the group average burnup by the total uptimes for all cycles that the fuel was in the core. As explained previously in Sect. 2.2, the ratios of uptime to downtime for cycles 1 and 2 were used to determine the length of downtime following each burnup interval for the fuel in those cycles. No downtime was applied for any of the fuel groups during cycle 3, since SNIKR performed the downtime decay calculation via ORIGEN-S for the MOC-3 restart.

A copy of the SAS2H input for fuel group 1 is included in Appendix B. With the exception

of the uranium isotopics, the burnup steps, and the BPR data, inputs for the other fuel group calculations were identical.

\subsection{BURNUP-DEPENDENT INTERPOLATION OF ISOTOPICS}

The atom density output files from each of the previous SAS2H calculations contain isotopic concentrations for the associated fuel group at each burnup step. Using the appropriate group output, SNIKR1 was used to interpolate between burnup intervals in order to estimate the isotopic concentration corresponding to the burnup of each assembly and cross-section set in the Sequoyah 2 models at BOC-3 and MOC-3. SNIKR1 then used these isotopics (which represented nuclide concentrations at the end of the depletion prior to the critical condition at BOC-3 or MOX-3) and prepared an ORIGEN-S decay calculation to obtain the concentration of the isotopes after the 
Table 13. Cross-section sets for one-eighth-core assemblies

\begin{tabular}{|c|c|c|c|c|c|}
\hline \multicolumn{3}{|c|}{ BOC } & \multicolumn{3}{|c|}{ MOC } \\
\hline $\begin{array}{c}\text { Cross-section } \\
\text { set No. }\end{array}$ & $\begin{array}{c}\text { Assembly } \\
\text { No. }\end{array}$ & $\begin{array}{c}\text { Burnup } \\
\text { (MWd/MTU) }\end{array}$ & $\begin{array}{c}\text { Cross-section } \\
\text { set No. }\end{array}$ & $\begin{array}{c}\text { Assembly } \\
\text { No. }\end{array}$ & $\begin{array}{c}\text { Burnup } \\
\text { (MWd/MTU) }\end{array}$ \\
\hline \multirow[t]{3}{*}{1} & 5 & 23,637 & \multirow[t]{3}{*}{1} & 5 & 30,812 \\
\hline & 27 & 25,339 & & 27 & 31,622 \\
\hline & Average & 24,488 & & Average & 31,217 \\
\hline \multirow[t]{5}{*}{2} & 1 & 21,182 & \multirow[t]{5}{*}{2} & 1 & 29,434 \\
\hline & 7 & 22,226 & & 13 & 29,506 \\
\hline & 13 & 21,645 & & 20 & 28,555 \\
\hline & 20 & 20,877 & & 31 & 27,263 \\
\hline & Average & 21,483 & & Average & 28,713 \\
\hline \multirow[t]{5}{*}{3} & 16 & 23,043 & \multirow[t]{5}{*}{3} & 7 & 30,246 \\
\hline & 18 & 23,685 & & 16 & 31,051 \\
\hline & 22 & 24,587 & & 18 & 31,312 \\
\hline & 31 & 24,497 & & 22 & 32,147 \\
\hline & Average & 23,953 & & Average & 31,213 \\
\hline \multirow[t]{2}{*}{4} & 9 & 26,859 & \multirow[t]{2}{*}{4} & 9 & 34,555 \\
\hline & Average & 26,859 & & Average & 34,555 \\
\hline \multirow[t]{3}{*}{5} & 26 & 8,618 & \multirow[t]{3}{*}{5} & 26 & 13,362 \\
\hline & 29 & 8,550 & & 29 & 14,546 \\
\hline & Average & 8,584 & & Average & 13,954 \\
\hline \multirow[t]{4}{*}{6} & 12 & 11,846 & \multirow[t]{4}{*}{6} & 12 & 21,023 \\
\hline & 23 & 10,575 & & 23 & 19,376 \\
\hline & 28 & 10,711 & & 28 & 18,755 \\
\hline & Average & 11,044 & & Average & 19,718 \\
\hline \multirow[t]{5}{*}{7} & 3 & 13,137 & \multirow[t]{5}{*}{7} & 3 & 23,062 \\
\hline & 10 & 13,298 & & 10 & 22,810 \\
\hline & 11 & 14,229 & & 11 & 23,784 \\
\hline & 24 & 14,185 & & 24 & 22,943 \\
\hline & Average & 13,712 & & Average & 23,162 \\
\hline \multirow[t]{3}{*}{8} & 15 & 0 & \multirow[t]{3}{*}{8} & 15 & 8,177 \\
\hline & 21 & 0 & & 21 & 7,306 \\
\hline & Average & 0 & & Average & 7,742 \\
\hline \multirow[t]{4}{*}{9} & 14 & 0 & \multirow[t]{4}{*}{9} & 14 & 9,935 \\
\hline & 19 & 0 & & 19 & 9,506 \\
\hline & 25 & 0 & & 25 & 9,019 \\
\hline & Average & 0 & & Average & 9,487 \\
\hline \multirow[t]{3}{*}{10} & 8 & 0 & \multirow[t]{3}{*}{10} & 8 & 8,060 \\
\hline & 30 & 0 & & 30 & 7,366 \\
\hline & Average & 0 & & Average & 7,713 \\
\hline \multirow[t]{5}{*}{11} & 2 & 0 & \multirow[t]{5}{*}{11} & 2 & 10,102 \\
\hline & 4 & 0 & & 4 & 9,787 \\
\hline & 6 & 0 & & 6 & 9,755 \\
\hline & 17 & 0 & & 17 & 10,119 \\
\hline & Average & 0 & & Average & 9,977 \\
\hline
\end{tabular}


Table 14. Cross-section sets for Sequoyah Unit 2 Cycle 3 BOC

\begin{tabular}{ccccccc}
\hline $\begin{array}{c}\text { Cross-section } \\
\text { set No. }\end{array}$ & Enrichment & BPRs & $\begin{array}{c}\text { SAS2H } \\
\text { fuel } \\
\text { group }\end{array}$ & $\begin{array}{c}\text { Average } \\
\text { burnup } \\
\text { (MWd/MTU) }\end{array}$ & $\begin{array}{c}\text { Burnup } \\
\text { range } \\
\text { (MWd/MTU) }\end{array}$ & $\begin{array}{c}\text { No. of } \\
\text { assemblies }\end{array}$ \\
\hline 1 & 2.6 & No & 1 & 24,488 & $23,637-25,339$ & 2 \\
2 & 3.1 & No & 2 & 21,483 & $20,877-22,226$ & 4 \\
3 & 3.1 & No & 2 & 23,953 & $23,043-24,587$ & 4 \\
4 & 3.1 & No & 2 & 26,859 & 26,859 & 1 \\
5 & 3.5 & No & 3 & 8,584 & $8,550-8,618$ & 2 \\
6 & 3.5 & No & 3 & 11,044 & $10,575-11,846$ & 3 \\
7 & 3.5 & No & 3 & 13,712 & $13,137-14,229$ & 4 \\
8 & 3.8 & No & 4 & 0 & 0 & 2 \\
9 & 3.8 & Yes & 5 & 0 & 0 & 3 \\
10 & 3.6 & No & 6 & 0 & 0 & 2 \\
11 & 3.6 & Yes & 7 & 0 & 0 & 4 \\
\hline
\end{tabular}

Table 15. Cross-section sets for Sequoyah Unit 2 Cycle 3 MOC

\begin{tabular}{ccccccc}
\hline $\begin{array}{c}\text { Cross-section } \\
\text { set no. }\end{array}$ & Enrichment & BPRs & $\begin{array}{c}\text { SAS2H } \\
\text { fuel } \\
\text { group }\end{array}$ & $\begin{array}{c}\text { Average } \\
\text { burnup } \\
\text { (MWd/MTU) }\end{array}$ & $\begin{array}{c}\text { Burnup } \\
\text { range } \\
\text { (MWd/MTU) }\end{array}$ & $\begin{array}{c}\text { No. of } \\
\text { assemblies }\end{array}$ \\
\hline 1 & 2.6 & No & 1 & 31,217 & $30,812-31,622$ & 2 \\
2 & 3.1 & No & 2 & 28,713 & $27,263-29,506$ & 4 \\
3 & 3.1 & No & 2 & 31,213 & $30,246-32,147$ & 4 \\
4 & 3.1 & No & 2 & 34,555 & 34,555 & 1 \\
5 & 3.5 & No & 3 & 13,954 & $13,362-14,546$ & 2 \\
6 & 3.5 & No & 3 & 19,718 & $18,755-21,023$ & 3 \\
7 & 3.5 & No & 3 & 23,162 & $22,810-23,784$ & 4 \\
8 & 3.8 & No & 4 & 7,742 & $7,306-8,177$ & 2 \\
9 & 3.8 & Yes & 5 & 9,487 & & 3 \\
10 & 3.6 & No & 6 & 7,713 & $9,019-9,935$ & 2 \\
11 & 3.6 & Yes & 7 & 9,977 & & \\
& & & & & & \\
\end{tabular}


Table 16. SAS2H operating history data by fuel group and cycle

\begin{tabular}{|c|c|c|c|c|c|c|c|c|}
\hline $\begin{array}{l}\text { SAS2H } \\
\text { fuel } \\
\text { group }\end{array}$ & $\begin{array}{c}\text { Reactor } \\
\text { cycles }\end{array}$ & $\begin{array}{c}\text { Average } \\
\text { power } \\
\text { (MW/MTU) }\end{array}$ & $\begin{array}{l}\text { Actual } \\
\text { uptime } \\
\text { (d) }\end{array}$ & $\begin{array}{c}\text { Actual } \\
\text { downtime } \\
\text { (d) }\end{array}$ & $\begin{array}{c}\text { Number of } \\
\text { intervals @ } \\
\text { burnup per } \\
\text { interval } \\
\text { (GWd/MTU) }\end{array}$ & $\begin{array}{l}\text { Modeled } \\
\text { burn time } \\
\text { per interval } \\
\text { (d) }\end{array}$ & $\begin{array}{c}\text { Modeled } \\
\text { downtime } \\
\text { per interval } \\
\text { (d) }\end{array}$ & $\begin{array}{l}\text { Cumulative } \\
\text { burnup } \\
\text { (GWd/MTU) }\end{array}$ \\
\hline 1 & 1 and 2 & 33.939 & 684 & 318 & $5 @ 5$ & 147.32 & 69.33 & 25 \\
\hline 1 & $3^{a}$ & 33.939 & 205 & 0 & $3 @ 5$ & 147.32 & 0 & 40 \\
\hline 2 & 1 and 2 & 34.132 & 684 & 318 & 5@5 & 146.49 & 68.94 & 25 \\
\hline 2 & $3^{a}$ & 34.132 & 205 & 0 & 4@5 & 146.49 & 0 & 45 \\
\hline 3 & 2 & 41.468 & 272 & 153 & 2@5 & 120.58 & 67.82 & 10 \\
\hline 3 & $3^{a}$ & 41.468 & 205 & 0 & $4 @ 5$ & 120.58 & 0 & 30 \\
\hline 4 & $3^{a}$ & 37.765 & 205 & 0 & $4 @ 5$ & 79.439 & 0 & 20 \\
\hline 5 & $3^{a}$ & 46.278 & 205 & 0 & $4 @ 5$ & 64.826 & 0 & 20 \\
\hline 6 & $3^{a}$ & 37.625 & 205 & 0 & 4@5 & 79.734 & 0 & 20 \\
\hline 7 & $3^{a}$ & 48.666 & 205 & 0 & $5 @ 5$ & 61.645 & 0 & 25 \\
\hline
\end{tabular}

${ }^{a}$ To the MOC-3. 
appropriate downtimes of 0.42 and 2.73 years prior to the BOC-3 startup and the MOC-3 restart, respectively. For the HFP cases, this step was followed by an ORIGEN-S depletion of $100 \mathrm{~h}$ at HFP in order to obtain the HFP equilibrium xenon concentration for each assembly. Since the assemblyaverage relative power distribution at the time of the restart was not available, each fuel assembly was assumed to be at the core-average power level for generating the equilibrium xenon concentrations. Because SNIKR1 set up the ORIGEN-S decay on a basis of atoms/b-cm, the power was converted from MW/MTU to MW/b-cm.MTU per atom. The conversion factor for Westinghouse $17 \times 17$ fuel was calculated as 5.51884E-6. The core average power level assumed for Sequoyah Unit 2 was 37.90 MW/MTU, or 2.0916E-4 MW/atom/b-cm. The necessary input files for the HFP depletion were the ORIGEN-S restart file from the downtime decay and the SAS2H cross-section library from the previous SAS2H depletion. After ORIGEN-S was executed, SNIKR3 read the ORIGEN-S output and prepared isotopic concentration tables in both SCALE standard composition input format and KENO mixing table format, for the selected set of isotopes listed previously in Table 2.

The SNIKR sequence consists of three codes, as previously described in Sect. 2.3, and requires two files. The first file is a SNIKR input file describing the calculation to be performed for a specific assembly or cross-section set; the second is the SAS2H output file containing the atom density data for the appropriate fuel group. SNIKR calculations are automated in a manner similar to SCALE calculational sequences such that the multistep calling of the individual code packages is transparent to the user. Appendix C lists a user input guide for SNIKR Version 1.0, which was used in these analyses, and FORTRAN listings of SNIKR1 and SNIKR3. The SAS2H and SNIKR calculations were performed on the ORNL IBM/MVS 3090 mainframe computer using SCALE-4.1.

SNIKR1 then used these isotopics (which represented nuclide concentrations at the end of the depletion prior to the critical condition at BOC-3 or MOC-3) and prepared an ORIGEN-S decay calculation to obtain the concentration of the isotopes after the appropriate downtimes of 0.42 and 2.73 years prior to the BOC-3 startup and the MOC-3 restart, respectively. Slightly different approaches are taken between preparation of assembly isotopics and cross-section set isotopics because the results are used in different applications. The following subsections describe each of the two methods.

\subsubsection{Assembly Isotopics}

In the KENO V.a model of Sequoyah Unit 2 Cycle 3, eighth-core-averaged assembly isotopics calculations are used to provide the nuclide concentrations for each assembly position. The assembly isotopics are based on the average burnup for the assembly, and all fuel rods within the assembly are assumed to possess the same isotopic composition. Hence, material numbers for each fuel rod in a given assembly are identical and correspond to a specific KENO V.a mixture number. This mixture is defined based on results of SNIKR calculations for the burnup of the corresponding assembly. In the Sequoyah KENO V.a model, mixture numbers 101 through 131 correspond to SNIKR calculations for assemblies 1 through 31, respectively. Eighth-core-averaged assembly burnups are given in Table 12, along with fuel-group and cross-section set information.

Sample SNIKR input files for BOC and MOC are listed in Tables D.1 and E.1, respectively. As discussed earlier in Sect. 2.4, cross-section set-dependent cross sections are required only for the seven burnup-dependent actinides. SNIKR places the cross-section ID modifier in front of the default cross-section ID for each of these isotopes (e.g., ${ }^{238}$ U, with ID No. 92238, would be described as 
292238 for all assemblies located in cross-section set 2). Burnable poison isotopics were similarly generated for each of the seven eighth-core fuel assembly locations where BPRs were present in Cycle 3. Sample input files are listed in Tables D.2 and E.2.

The SNIKR output file consists of three sections: a summary of the input and coarsely formatted ORIGEN-S results, isotopic concentrations in SCALE standard composition input format, and isotopic concentrations in KENO V.a mixing table input format. For each assembly calculation, only the latter was of interest; this section was copied and placed directly into KENO V.a input to describe the isotopic composition for the burnup of a specific assembly. A sample SNIKR output is listed in Appendix C.

\subsubsection{Cross-Section Set Isotopics}

Burnup-dependent cross sections were required for the seven burnup-dependent actinides. As was previously mentioned, cross-section set calculations were performed with CSASN in order to obtain the cross sections for these actinides for each cross-section set based on the average burnup. Cross-section set groupings are shown in Table 13; these groupings were selected based on the burnup range criterion of $2 \mathrm{GWd} / \mathrm{MTU}$ discussed earlier. SNIKR calculations were required for all cross-section sets except the fresh fuel sets 8 through 11 at BOC, HZP. With the exception of crosssection set 4 , only the seven burnup-dependent actinides are needed for each set of burned fuel at BOC and MOC. Therefore, the 100-h HFP depletion following the downtime decay in ORIGEN-S was only performed for cross-section set 4, which included all the nuclides in Table 2 as well as those for all the nonfuel mixtures [clad, moderator, BPR (MOC only), and structural materials]. Example input files are shown in Tables D.3 and E.3.

The SNIKR output file is the same format as was produced for the assembly calculations; however, the region of output data which was of interest was different. The isotopic concentrations in SCALE standard composition input format were copied to a CSASN input file.

\subsection{GENERATION OF CROSS SECTIONS USING CSASN}

Problem-dependent cross-section libraries were produced using the CSASN sequence of SCALE; the details of this process were described in Sect. 2.4. For each cross-section set, a CSASN input deck containing cross-section set average isotopics was created. Because the physical geometries of all fuel pins were identical, input specifications were the same for all sets, with the exception of the isotopic compositions specified for each set. All cases were set up to use the SCALE ENDF/B-IV and ENDF/B-V based 27-group 27BURNUPLIB cross-section library. All calculations were LATTICECELL-type, with fuel in a Zircaloy clad, with dimensions as specified in Table 4. A borated-water moderator was specified, with the appropriate boron concentration. For $\mathrm{HZP}$, all components were specified with a temperature of $559 \mathrm{~K}\left(547^{\circ} \mathrm{F}\right)$, corresponding to $\mathrm{HZP}$ conditions. For HFP, appropriate temperatures from Table 4 were specified for each component. The example inputs for HZP and HFP, respectively, are shown in Tables D.4 and E.4.

Isotopic concentrations were obtained from the earlier SNIKR cross-section set calculations. Since only the seven burnup-dependent actinides were required, except for set 4 , all other actinides and fission products were deleted from the fuel mixture specifications for these cases. Cross-section sets 8 through 11, comprised only of fresh fuel at BOC, HZP, were specified using the fresh 
isotopic compositions given in Table 6 for that case. The microscopic cross-section calculations for cross-section set 4 also included the other actinides and fission products in the fuel mixture, along with mixtures for the BPR nuclides (MOC only), moderator, and structural materials. The microscopic cross-section calculations for cross-section set 11 included the BPR nuclides at BOC. The example input for cross-section set 4 is included as Tables D.5 and E.5. The nuclide IDs and atom densities for each of these mixtures were copied from the CSASN output to the KENO V.a mixing table. Cross-section set 4 was selected for these calculations because its spent fuel isotopics represented the highest burnup assembly (26,859 MWd/MTU at BOC and 34,555 MWd/MTU at $\mathrm{MOC}$ ) in the eighth-core model. The BPR nuclide concentrations at MOC were taken from the SNIKR/ORIGEN-S calculations previously performed for the BPR in eighth-core fuel assembly location 17, which was the highest burnup location (10,119 MWd/MTU) with BPRs. CSASN calculations were then performed, with the resulting microscopic working-format cross-section library saved for each cross-section set.

\subsection{COMBINING CROSS-SECTION SET LIBRARIES USING WAX}

The WAX progran 16 was used to combine the 11 individual working-format libraries (one per cross-section set) into a single library for each of the three reactor criticals to be used in the KENO V.a core calculations. For cross-section set 4, selected to include the fission products and additional actinides, WAX copied all cross sections into the combined library. For the cross-section set selected for the BPR cross sections (set 11 at BOC and 4 at MOC), WAX copied those cross sections in addition to the seven burnup-dependent actinides. For the remaining cross-section sets, WAX copied only the cross sections for the seven burnup-dependent actinides. For each of these actinides, the cross-section ID was modified by adding the cross-section set number as a prefix, to be consistent with the numbering scheme used in the SNIKR-produced KENO V.a mixing-tableformat isotopics for each assembly. Sample WAX input listings are provided in Tables D.6 and E.6. All CSASN and WAX calculations were performed with SCALE-4.1 on the ORNL IBM mainframe.

\subsection{VALIDATION OF CROSS-SECTION SET ASSUMPTIONS}

The methodology of cross-section generation employing cross-section sets resulted in each fuel assembly in the KENO V.a full-core model being modeled with microscopic cross sections generated with isotopics based on the average burnup for a cross-section set (i.e., a subgroup of fuel). In order to validate this methodology, the highest burnup assemblies at MOC in cross-section sets 3 and 6 were analyzed by executing an XSDRNPMㄹ eigenvalue calculation in stand-alone mode and via the CSAS1 ${ }^{6}$-sequence (BONAMI, NITAWL-II, XSDRNPM). The stand-alone calculations utilized the working-format libraries created by WAX that were based on cross-section set averaged isotopics. The CSAS1X calculations generated and used problem-specific microscopic cross sections based on the calculated assembly isotopics. Cross-section set 3 was selected for the validation because it represented the highest burnup cross-section set with a range of burnups. Cross-sectionset 6 was also selected because it had the largest minimum-to-maximum burnup range (2.23 MWd/MTU). The individual assemblies N38 and P17 were selected because they represented the maximum burnup, and, hence, the maximum difference in isotopics from the average, for their respective cross-section sets. These cases should give the poorest agreement since the change in 
microscopic cross sections should be greatest at higher burnups and for the largest difference in assembly-to-average burnup. Since assembly P17 had the largest difference at MOC, similar calculations were performed for it at BOC (HZP and HFP). The results of these cases are compared in Table 17, which shows a maximum difference of $0.085 \% \Delta \mathrm{k} / \mathrm{k}$ due to the use of the cross sections at subgroup averaged conditions. This suggests that subgroup-averaged cross sections with a burnup range of up to $2 \mathrm{MWd} / \mathrm{MTU}$ give a reasonable approximation to burnup-specific cross sections. Input datasets for assembly P17 are included in Tables D.7 and D.8 and E.7 and E.8.

Table 17. $\mathbf{k}_{\infty}$ comparison for validation of cross-section methodology

\begin{tabular}{cccccc}
\hline & & & \multicolumn{2}{c}{$\mathrm{k}_{\infty}$} & \\
\cline { 5 - 5 } Burnup & Power & $\begin{array}{c}\text { Assembly } \\
\text { ID }\end{array}$ & $\begin{array}{c}\text { XSDRNPM } \\
\text { stand-alone }\end{array}$ & $\begin{array}{c}\text { CSAS1X } \\
\text { sequence }\end{array}$ & \% Difference \\
\hline MOC & HFP & N38 & 0.896084 & 0.895497 & 0.065 \\
MOC & HFP & P17 & 1.00332 & 1.00247 & 0.085 \\
BOC & HZP & P17 & 1.04580 & 1.04527 & 0.051 \\
BOC & HFP & P17 & 1.04041 & 1.03985 & 0.054 \\
\hline
\end{tabular}

\subsection{PREPARATION OF KENO V.a CORE MODEL}

The KENO V.a model used to determine $\mathrm{k}_{\text {eff }}$ for the Sequoyah 2 BOC-3 and MOC-3 cores consists of four parts. The first section of input contains code parameter specifications. The only significant aspect of this section is the use of 1003 generations of 1000 neutrons per generation; hence, the calculation was based on one million histories (three generations were automatically skipped by KENO V.a). Parameter specifications are followed by mixture specifications, geometry specifications, and plotting specifications. The latter set is unimportant in the criticality calculation and was simply used in debugging and verifying geometry input. The following subsections describe the details of the material and geometry specifications for this model.

\subsubsection{KENO V.a Mixture Specifications}

In describing the composition of a fuel assembly, it has been assumed that all fuel rods in the assembly are identical and may be represented by the assembly-averaged burnup. No attempt was made to account for burnup asymmetries within an assembly, because this information was not readily available and should have little effect on the computed solution. Thus, only a single fuel rod description is necessary to describe all fuel rods in a given assembly. In addition, in this model, axial power distributions are ignored, and assemblies are represented by a model that assumes a constant (average) power distribution along the length of the assembly. Thus, the composition of fuel in an assembly is uniform and is represented by a single material specification. Based on the results of an

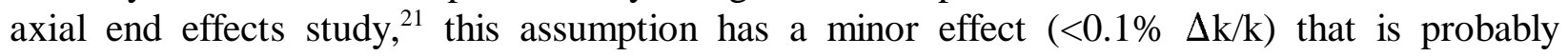


conservative for the average burnup in these models. Because it is possible to take advantage of the one-eighth-core symmetry of the core, only 31 assemblies are required to represent all 193 assembly positions in the core. Hence, only 31 material mixtures are necessary for the full-core model. These come from the 31 assembly calculations performed earlier using SNIKR for mixtures 101 through 131. The portions of the SNIKR output copied into the KENO V.a input represent complete mixture specifications for each of the 31 materials.

Material specifications were also required for all remaining materials (i.e., clad, borated water, and BPR materials). Concentrations for each isotope were obtained from the output of the CSASN cross-section calculations. Mixture numbers 11 through 17 were used for the burnable poison materials. A unique mixture number was assigned the BPR in each eighth-core fuel assembly that contained BPRs. This unique mixture number was necessary for the MOC-3 case where the BPRs were partially depleted and varied with assembly burnup. Table 18 lists all materials included in the core model by mixture number.

Table 18. Mixtures in KENO V.a model

\begin{tabular}{cl}
$\begin{array}{c}\text { Mixture } \\
\text { No. }\end{array}$ & \multicolumn{1}{c}{ Description } \\
\hline 1 & Clad \\
2 & Stainless steel (BP clad, baffle) \\
3 & Borated moderator \\
4 & $50 \%$ borated moderator, 50\% stainless steel (top and bottom \\
5 & reflector) \\
6 & Stainless steel (core barrel) \\
7 & Borated moderator (outside core barrel) \\
8 & Stainless steel (thermal shield) \\
9 & Borated moderator (outside thermal shield) \\
$11-17$ & Stainless steel (reactor vessel) \\
$101-131$ & Burnable poison, assemblies 2, 4, 6, 14, 17, 19, 25 \\
& Fuel, assemblies 1-31 \\
\hline
\end{tabular}

\subsubsection{KENO V.a Geometry Specifications}

A fuel rod was defined for each of the 31 one-eighth-core fuel assemblies based on the dimensions given in Table 4. Identical dimensions were used for all rod definitions. Fuel rods were assigned to unit numbers 101 to 131, respectively; the fuel region of each rod was linked to its corresponding material number (e.g., fuel rod 101 used material 101 for the fuel region). All rods were specified with a void gap and Zircaloy clad, centered in a water cuboid. Fuel rods and enclosing cuboids were modeled as having a length equal to that of the active fuel length of the rod (i.e., fuel assembly top and bottom structures were neglected). A 50/50 mixture of borated $\mathrm{H}_{2} \mathrm{O}$ and stainless 
steel was used as a top and bottom reflector $(25 \mathrm{~cm}$ thick) to account for structural materials above and below the active fuel region.

Unit 161, representing a control rod guide tube, was created using the dimensions in Table 4, with water inside the tube and centered within a water cuboid. Burnable poison rods were created as Units 162 through 168. Each BPR was put inside a control rod guide tube.

The remaining array locations were appropriately filled with guide tubes or BPRs according to the full-core BPR loading configuration in Fig. 5 and the fuel assembly lattice arrangements in Fig. 4. Each array was surrounded by a thin layer of moderator in order to obtain an assembly lattice spacing of $21.50364 \mathrm{~cm}$ (8.466 in.).

The core baffle surrounding the outermost assemblies was created as a composite of several smaller segments, comprised of four different cuboid shapes. Units 41 to 44 were used to define these shapes. Figure 7 illustrates the use of these four unit types in modeling the core baffle. The figure also shows assembly position numbers for the full core, based on one-eighth-core symmetry and the numbering scheme shown in Fig. 6. Using these position numbers, arrays of assemblies and core baffle segments were used to define larger units, to minimize the number of KENO V.a "holes" placed in the global unit. Figure 8 illustrates the grouping of assemblies used. Global Unit 70 contained the core barrel, thermal shield, and reactor vessel. All other units were placed within Unit 70 using KENO V.a "holes." Note that core baffle components drawn in black in the figure represent individual components not included in these arrays and were entered as individual holes in the global array. Unit number assignments used in the model are given in Table 19.

This discussion completes the geometric description of the core. As a reference, a listing of the entire KENO V.a input for the BOC-3 HZP or HFP cases and the MOC-3 HFP case are included in Tables D.9, D.10, and E.9, respectively. All KENO V.a calculations were performed with SCALE4.2 on an IBM RS-6000 workstation after the cross-section libraries created with WAX had been transferred from the ORNL IBM mainframe. 
ORNL-DWG 94-12312

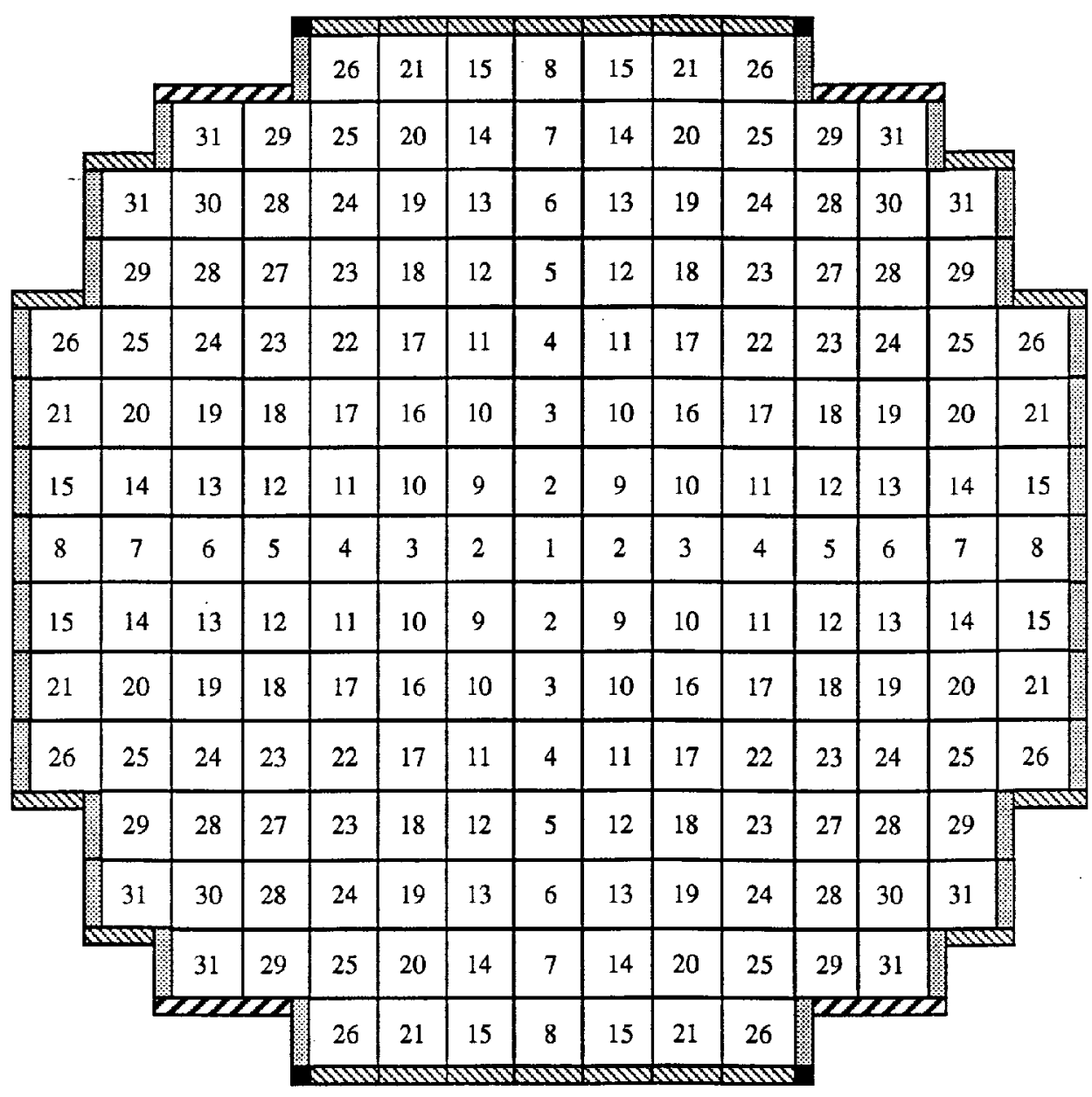

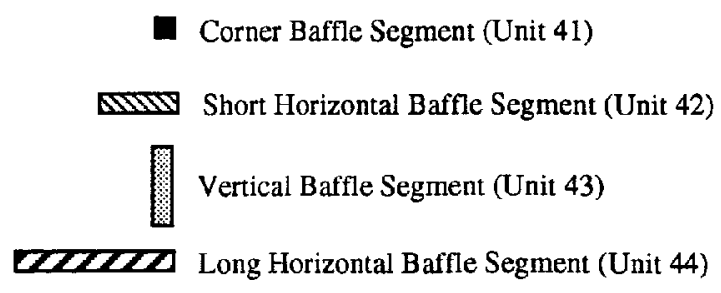

Fig. 7. Full-core assembly positions and core baffle configuration. 
ORNL-DWG 94-12313

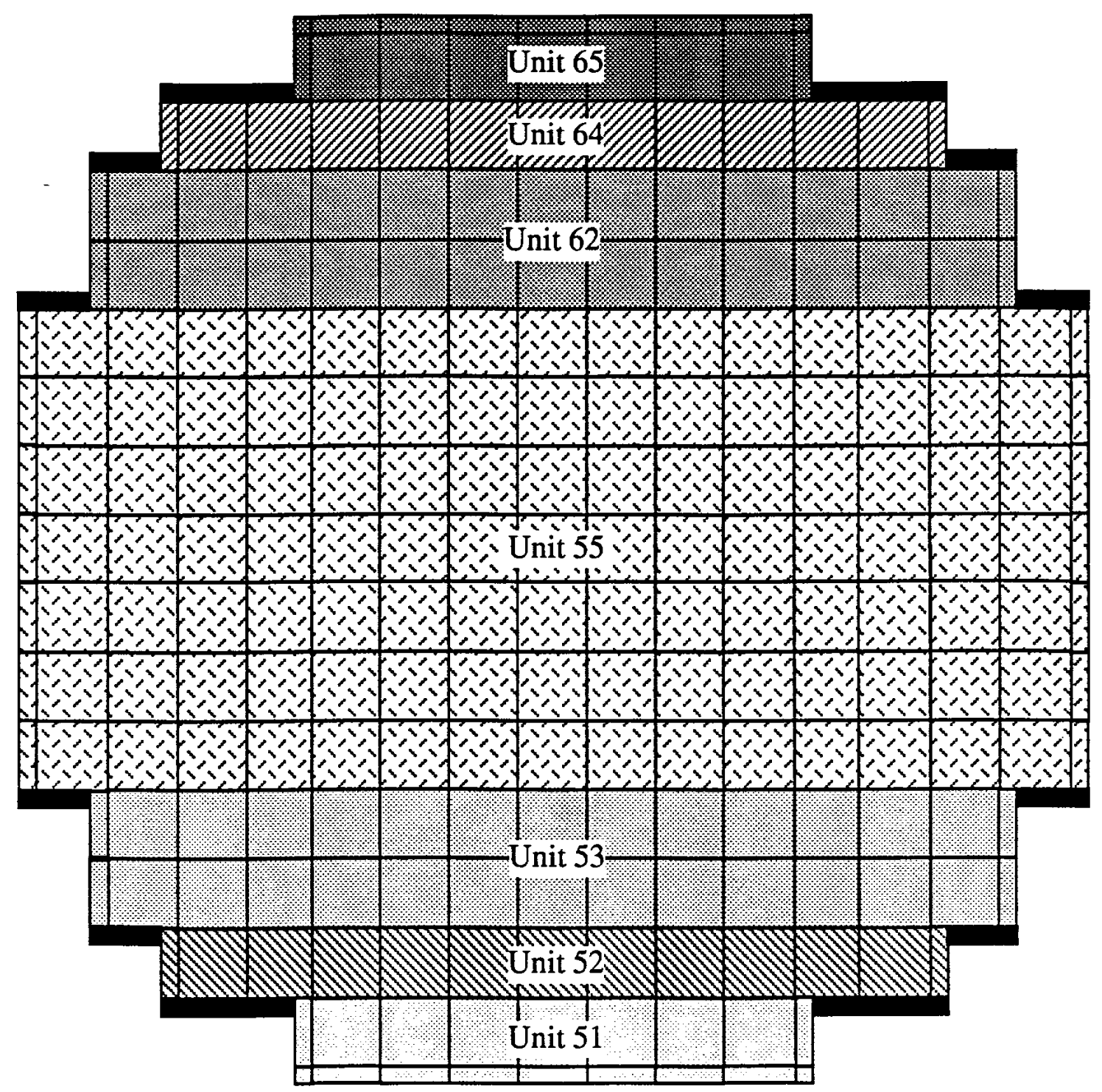

Fig. 8. KENO V.a unit definitions based on component arrays. 
Table 19. Unit numbers used in Sequoyah KENO V.a core model

Unit

No. Description

$1-31$

41

42

43

44

51

52

53

54

62

64

65

70 (GLOBAL) 101-131

161

$162-168$
Fuel assemblies for positions 1 to 31 , respectively

$2.8575 \times 2.8575 \mathrm{~cm}$ (corner) segment of core baffle

$21.50364 \times 2.8575 \mathrm{~cm}$ (horizontal) segment of core baffle

$2.8575 \times 21.50364 \mathrm{~cm}$ (vertical) segment of core baffle

$43.00728 \times 2.8575 \mathrm{~cm}$ (horizontal) segment of core baffle

"Bottom" of baffle + row 1 of assemblies + vertical baffle ends

Row 2 of assemblies + vertical baffle ends

Rows 3 and 4 of assemblies + vertical baffle ends

Rows 5-11 of assemblies + vertical baffle ends

Rows 12 and 13 of assemblies + vertical baffle ends

Row 14 of assemblies + vertical baffle ends

Row 15 of assemblies + vertical baffle ends + "top" of baffle

Reactor vessel + thermal shield + core barrel + vertical baffle ends

Fuel rods for assemblies 1-31, respectively

Water-filled control rod guide tube

BPRs in control rod guide tubes 


\section{RESULTS AND CONCLUSIONS}

The KENO V.a criticality calculations for the Sequoyah 2 Cycle 3 BOC and MOC models described in this report yielded values for $\mathrm{k}_{\text {eff }}$ from 1.0039 to 1.0067 , as shown in Table 20. These results display great consistency for different burnup, power, xenon, and temperature conditions. The range of conditions for these reactor criticals are listed in Table 21. The MOC-3 case is unique among the reactor critical calculations reported in all the volumes of this report because it is the only core that contains all spent fuel. These results are based on 1000 generations of 1000 neutrons per generation, for a total of $1 \times 10^{6}$ histories. Included in Table 20 is the average fission group reported by SCALE, which represents the average neutron energy at which fission occurs. Numerical experiments with a different starting random number and different starting source shape and location indicate that these solutions are well converged and adequate source sampling achieved (see ref. 7 for discussion of what constitutes convergence).

The results in Table 20 were based on $\mathrm{P}_{3}$ scattering; however, a test case using (default) $\mathrm{P}_{1}$ scattering showed no significant change (within $0.1 \%$ ) in $\mathrm{k}_{\text {eff }}$. This result is as would be expected, since angular fluxes throughout a reactor core would be expected to be relatively uniform except near the outer boundary of the core.

Relative fission density distributions computed by KENO V.a are shown in Figs. 9, 10, and 11 for a one-eighth-core average. These may be interpreted as relative power densities, and show the approximate shape expected for an operating PWR core, indicating no major anomalies in the core assembly model. The use of uniform temperature and xenon distributions for the HFP cases causes the KENO V.a distributions to be less uniform over the inner-core regions due to the lack of xenon and temperature feedback mechanisms. Note that while $\mathrm{k}_{\mathrm{eff}}$, a total system parameter, is considered to be well converged, individual assembly fission distributions are based on substantially fewer histories, especially in outer-core regions, and therefore are subject to significantly higher uncertainties.

The results of these calculations demonstrate that even with a relatively simple core model and eighth-core and assembly-averaged burnups, it is possible to closely predict, in a best-estimate fashion, the critical condition after a long decay period for a lattice primarily comprised of spent fuel assemblies. Results are also consistent with SCALE validation calculations performed based on experiments using mixed-oxide fuel rods in square lattice configurations $\frac{22}{22}$ Hence, one may conclude that the methodology applied in performing these reactor critical calculations is valid for performing criticality safety analyses for systems with spent fuel. 
Table 20. KENO V.a calculated results for Sequoyah Unit 2 Cycle 3

\begin{tabular}{cccccc}
\hline Burnup & Power & $\begin{array}{c}\text { Boron } \\
(\mathrm{ppm})\end{array}$ & $\mathrm{k}_{\text {eff }}$ & $\begin{array}{c}\text { Average energy } \\
\text { group where } \\
\text { fission occurs }\end{array}$ & $\begin{array}{c}\text { Neutron } \\
\text { histories }\end{array}$ \\
\hline BOC & HZP & 1685 & $1.0039 \pm 0.0005$ & $20.4868 \pm 0.0037$ & $1,000,000$ \\
BOC & HFP & 1150 & $1.0067 \pm 0.0005$ & $20.3822 \pm 0.0035$ & $1,000,000$ \\
MOC & HFP & 475 & $1.0046 \pm 0.0005$ & $20.4437 \pm 0.0037$ & $1,000,000$ \\
\hline
\end{tabular}

${ }^{a}$ The energy range for group 20 is 0.8 to $0.4 \mathrm{eV}$.

Table 21. Range of conditions for Sequoyah reactor criticals

\begin{tabular}{lclllc}
\hline & $\begin{array}{c}\text { Core avg. } \\
\text { burnup } \\
\text { Case }\end{array}$ & $\begin{array}{l}\text { Power } \\
(\mathrm{MW})\end{array}$ & $\begin{array}{l}\text { Mod. } \\
\text { temp. } \\
\left({ }^{\circ} \mathrm{F}\right)\end{array}$ & $\begin{array}{l}\text { Fuel } \\
\text { temp. } \\
\left({ }^{\circ} \mathrm{F}\right)\end{array}$ & $\begin{array}{c}\text { Xenon } \\
\text { worth } \\
(\% \Delta \mathrm{k} / \mathrm{k})\end{array}$ \\
\hline BOC,HZP & 10,998 & 0 & 547 & 547 & 0 \\
BOC,HFP & 11,148 & 3,411 & 582 & 1162 & 2.64 \\
MOC,HFP & 19,248 & 3,411 & 582 & 1162 & 2.95 \\
\hline
\end{tabular}


ORNL-DWG 92M-8306R

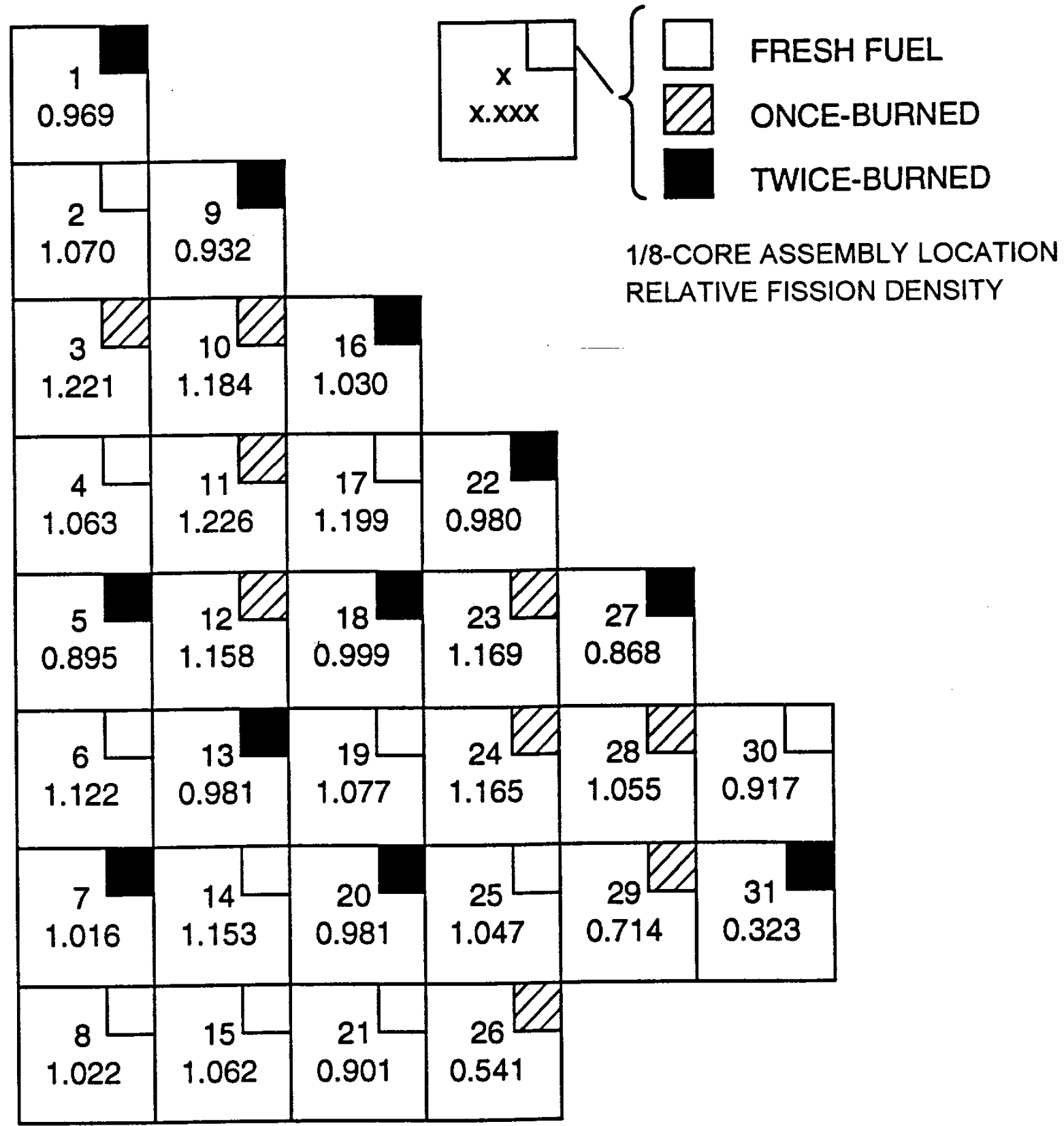

Fig. 9. BOC, HZP eighth-core relative fission density distribution. 
ORNL-DWG 92M-8307R

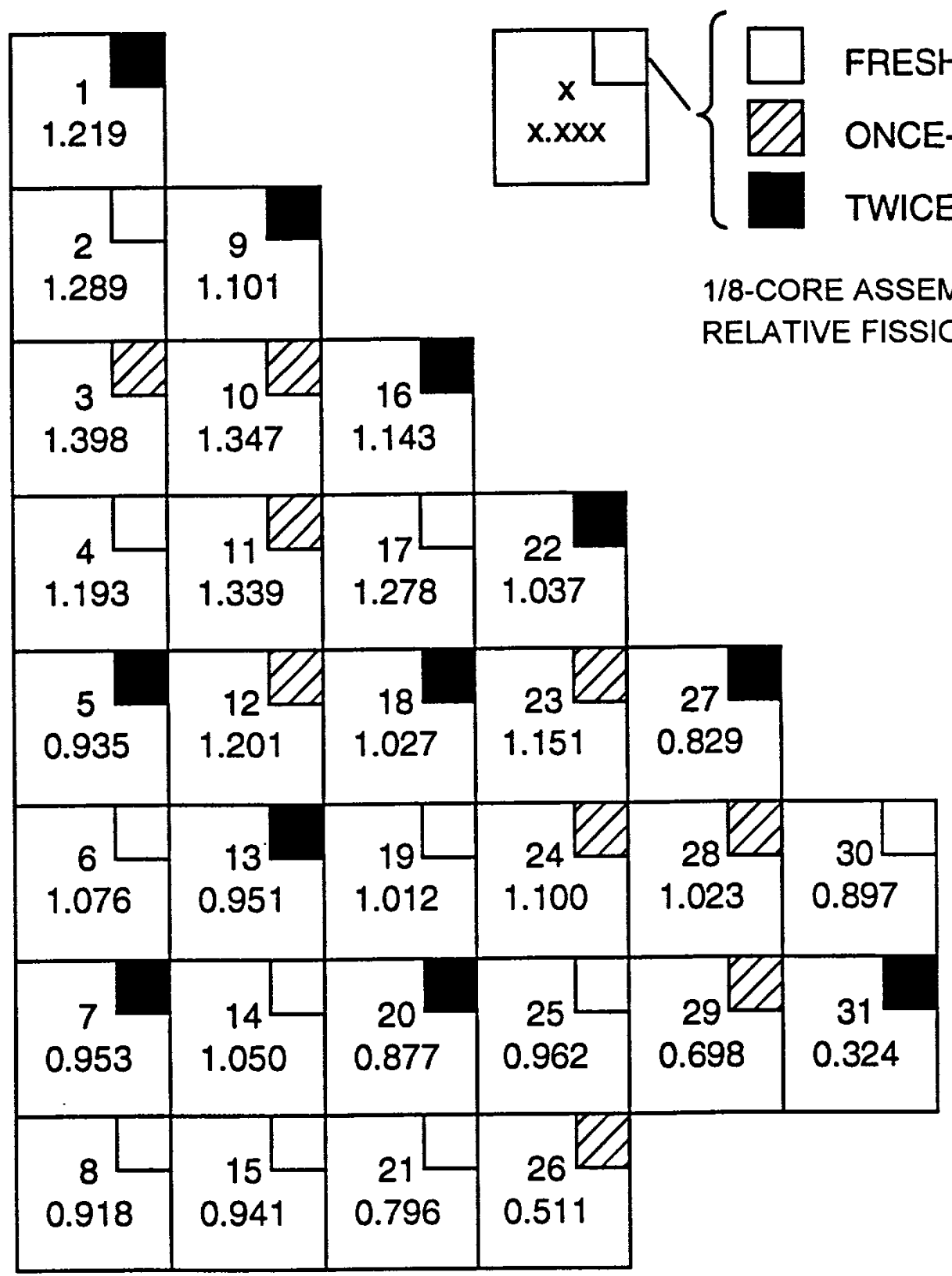

Fig. 10. BOC, HFP eighth-core relative fission density distribution. 
ORNL-DWG 92M-8872R

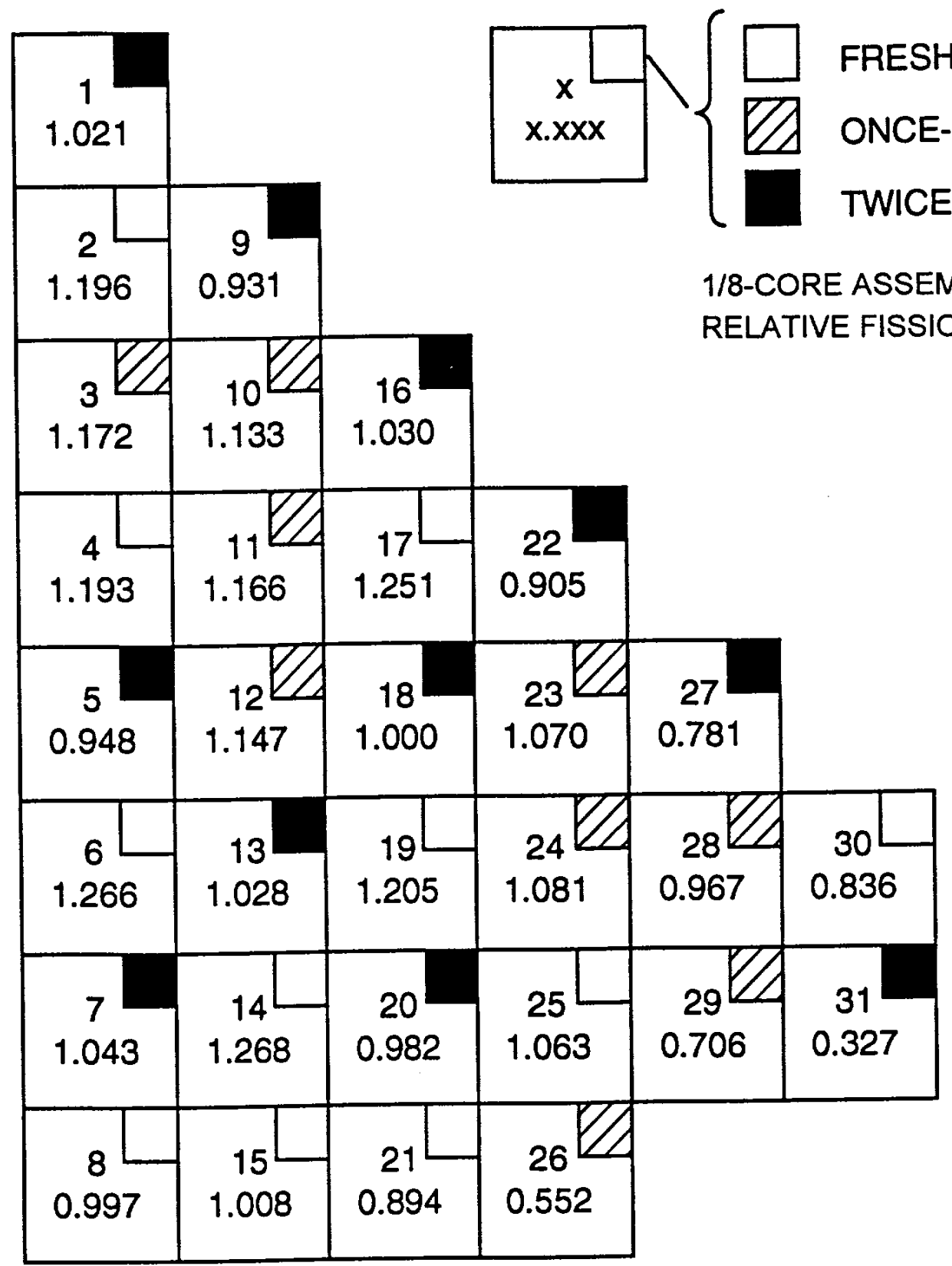

Fig. 11. MOC, HFP eighth-core relative fission density distribution. 


\section{REFERENCES}

1. T. L. Sanders and R. M. Westfall, "Feasibility and Incentives for Burnup Credit in Spent Fuel Transport Casks," Nucl. Sci. Eng. 104 (1990).

2. "American National Standard for Nuclear Criticality Safety in Operations with Fissionable Materials Outside Reactors," ANSI/ANS-8.1-1983.

3. SCALE: A Modular Code System for Performing Standardized Computer Analyses for Licensing Evaluation, NUREG/CR-0200, Rev. 4 (ORNL/NUREG/CSD-2/R4), Vols. 1, 2, and 3 (February 1995). Available from Radiation Shielding Information Center as CCC-545.

4. M. C. Brady and T. L. Sanders, "A Validated Methodology for Evaluating Burnup Credit in Spent Fuel Casks," Proc. International Conference on Nuclear Criticality Safety, Christ Church, Oxford, United Kingdom, September 9-31, 1991.

5. O. W. Hermann and C. V. Parks, "SAS2H: A Coupled One-Dimensional Depletion and Shielding Analysis Code," Sect. S2 of SCALE: A Modular Code System for Performing Standardized Computer Analyses for Licensing Evaluation, NUREG/CR-0200, Rev. 4 (ORNL/NUREG/CSD-2/R5), Vols. 1, 2 and 3 (February 1995). Available from Radiation Shielding Information Center as CCC-545.

6. N. F. Landers and L. M. Petrie, "CSAS4: An Enhanced Criticality Safety Analysis Module with an Optimum Pitch Search Option," Sect. C4 of SCALE: A Modular Code System for Performing Standardized Computer Analyses for Licensing Evaluation, NUREG/CR-0200, Rev. 4 (ORNL/NUREG/CSD-2/R5), Vols. 1, 2 and 3 (February 1995). Available from Radiation Shielding Information Center as CCC-545.

7. L. M. Petrie and N. F. Landers, "KENO V.a: An Improved Monte Carlo Criticality Program with Supergrouping," Sect. F11 of SCALE: A Modular Code System for Performing Standardized Computer Analyses for Licensing Evaluation, NUREG/CR-0200, Rev. 4 (ORNL/NUREG/CSD-2/R4), Vols. 1, 2, and 3 (February 1995). Available from Radiation Shielding Information Center as CCC-545.

8. J.-P. Renier and C. V. Parks, "Reactor Critical Calculations for Validation of Burnup Credit Analysis Methods," Trans. Am. Nucl.Soc. 62, 317 (1990).

9. O. W. Hermann and R. M. Westfall, "ORIGEN-S: A SCALE System Module to Calculate FuelDepletion, Actinide Transmutation, Fission Product Buildup and Decay, and Associated Radiation Source Terms," Sect. F7 of SCALE: A Modular Code System for Performing Standardized Computer Analyses for Licensing Evaluation, NUREG/CR-0200, Rev. 5 (ORNL/NUREG/CSD-2/R5), Vols. 1, 2 and 3 (February 1995). Available from Radiation Shielding Information Center as CCC-545. 
10. B. H. Wakeman and S. A. Ahmed, Evaluation of Burnup Credit for Dry Storage Casks, EPRI NP-6494, Electric Power Research Institute, August 1989.

11. O. W. Hermann and M. C. Brady, Comparisons of SAS2H and CASMO-3 Benchmark $k_{\infty}$ Calculations for Reactor Fuel With and Without Burnable Poisons, ORNL/TM-12490, Martin Marietta Energy Systems, Inc., Oak Ridge Natl. Lab. (to be published).

12. B. L. Broadhead et al., Investigation of Nuclide Importance to Functional Requirements Related to Transport and Long Term Storage of LWR Spent Fuel, ORNL/TM-12742 (in press).

13. D.G. Napolitano and D. G. Adli, Burnup Credit Criticality Analysis Using Advanced Nodal Techniques, Yankee Atomic Electric Co., March 1992.

14. N. M. Greene, "BONAMI-S: Resonance Self-Shielding by the Bondarenko Method," Sect. F1 of SCALE: A Modular Code System for Performing Standardized Computer Analyses for Licensing Evaluation, NUREG/CR-0200, Rev. 4 (ORNL/NUREG/ CSD-2/R5), Vols. 1, 2 and 3 (February 1995). Available from Radiation Shielding Information Center as CCC-545.

15. N. M. Greene, L. M. Petrie, and R. M. Westfall, "NITAWL-II: SCALE System Module for Performing Resonance Shielding and Working Library Production," Sect. F2 of SCALE: A Modular Code System for Performing Standardized Computer Analyses for Licensing Evaluation, NUREG/CR-0200, Rev. 4 (ORNL/NUREG/ CSD-2/R5), Vols. 1, 2 and 3 (February 1995). Available from Radiation Shielding Information Center as CCC-545.

16. N. M. Greene, "User's Guide for Utility Modules," Sect. M15 of SCALE: A Modular Code System for Performing Standardized Computer Analyses for Licensing Evaluation, NUREG/CR-0200, Rev. 4 (ORNL/NUREG/ CSD-2/R5), Vols. 1, 2 and 3 (February 1995). Available from Radiation Shielding Information Center as CCC-545.

17. O. W. Hermann, J-P. Renier, and C. V. Parks, Technical Support for a Proposed Decay Heat Guide Using SAS2H/ORIGEN-S Data, NUREG/CR-5625 (ORNL-6698), Martin Marietta Energy Systems, Inc., Oak Ridge Natl. Lab., 1994.

18. G. W. Morey, The Properties of Glass, 2nd ed., Reinhold, New York, 1954.

19. F. W. Walker, J. R. Parrington, and F. Feiner (revisors of edition), Nuclides and Isotopes, 14th ed., General Electric Co., San Jose, California, 1989. 
20. N. M. Greene and L. M. Petrie, "XSDRNPM-S: A One-Dimensional Discrete-Ordinates Code for Transport Analysis," Sect. F3 of SCALE: A Modular Code System for Performing Standardized Computer Analyses for Licensing Evaluation, NUREG/CR-0200, Rev. 4 (ORNL/NUREG/CSD-2/R4), Vols. 1, 2, and 3 (February 1995). Available from Radiation Shielding Information Center as CCC-545.

21. S. E. Turner, "An Uncertainty Analysis-Axial Burnup Distribution Effects," Proc. Workshop Use of Burnup Credit in Spent Fuel Transport Casks, Washington, D.C., February 21-22, 1988, SAND89-0018, TTC-0884, UC-820, T. L. Sanders, Ed., Sandia National Laboratories, October 1989.

22. S. M. Bowman et al., "Validation of SCALE-4 for Burnup Credit Applications," Nucl. Tech. 110, 3 . 


\section{APPENDIX A}

\section{SEQUOYAH UNIT 2 CYCLE DATA}

Source data provided by the Tennessee Valley Authority are presented here for completeness. The boron letdown curves of the soluble boron in the coolant of Sequoyah Unit 2 Cycles 1, 2, and 3, are shown in Figs. A.1, A.2, and A.3, respectively. The initial core loading patterns of Cycles 1, 2, and 3 are shown in Figs. A.4, A.5, and A.6, respectively. The final burnup distributions in the core after Cycles 1 and 2 are shown in Figs. A.7 and A.8, respectively. The fuel assembly burnup data at the restart after the long downtime during the MOC 3 are listed in Table A.1. The startup and shutdown dates of each cycle, in addition to the operating history derived for the cycle, are shown in Table A.2. The average operating specific power and cycle times for each fuel region or batch were computed from the data in these two tables. 
Table A.1. Fuel assembly burnups at MOC restart during Cycle 3 of Sequoyah Unit 2

\begin{tabular}{|c|c|c|c|c|c|}
\hline Assembly & $\begin{array}{c}\text { Burnup } \\
\text { (MWd/MTU) }\end{array}$ & Assembly & $\begin{array}{c}\text { Burnup, } \\
\text { (MWd/MTU) }\end{array}$ & Assembly & $\begin{array}{c}\text { Burnup, } \\
\text { (MWd/MTU) }\end{array}$ \\
\hline M06 & 28334.64 & N31 & 28601.57 & P26 & 23449.75 \\
\hline M08 & 28058.42 & N32 & 28769.80 & $\mathrm{P} 27$ & 13244.69 \\
\hline M17 & 28084.44 & N33 & 29434.07 & $\mathrm{P} 28$ & 20724.66 \\
\hline M29 & 31431.33 & N34 & 31510.97 & P29 & 18724.36 \\
\hline M34 & 31425.06 & N35 & 32191.32 & P30 & 23068.39 \\
\hline M37 & 30775.18 & N36 & 27462.70 & P31 & 13445.33 \\
\hline M39 & 31057.30 & N38 & 32286.77 & P32 & 19320.21 \\
\hline M48 & 27849.47 & N39 & 31067.26 & P33 & 19461.05 \\
\hline M53 & 31907.16 & N40 & 28294.71 & P34 & 19235.61 \\
\hline M55 & 31726.18 & N41 & 30100.28 & P35 & 22289.99 \\
\hline M56 & 30841.37 & $\mathrm{~N} 42$ & 28916.20 & P36 & 19599.64 \\
\hline M62 & 30575.21 & N43 & 34879.55 & P37 & 20960.71 \\
\hline N01 & 31336.13 & N44 & 28955.16 & P38 & 23811.87 \\
\hline N02 & 30266.71 & N45 & 28564.19 & P39 & 14660.20 \\
\hline N04 & 28315.73 & N47 & 31393.15 & $\mathrm{P} 40$ & 19069.01 \\
\hline N05 & 30047.02 & $\mathrm{~N} 48$ & 29079.95 & $\mathrm{P} 41$ & 22573.95 \\
\hline N06 & 31297.18 & P01 & 13379.10 & $\mathrm{P} 42$ & 22775.40 \\
\hline N07 & 29936.54 & P02 & 22627.31 & $\mathrm{P} 43$ & 22713.77 \\
\hline N08 & 27178.31 & P03 & 14716.69 & $\mathrm{P} 44$ & 18493.12 \\
\hline N09 & 30891.21 & P04 & 21040.94 & $\mathrm{P} 45$ & 23665.38 \\
\hline N10 & 30027.35 & P05 & 14317.43 & P46 & 14411.91 \\
\hline N11 & 34352.87 & P06 & 14454.71 & $\mathrm{P} 47$ & 20752.01 \\
\hline N12 & 28742.42 & P07 & 19252.41 & $\mathrm{P} 48$ & 22780.55 \\
\hline N13 & 30340.93 & P08 & 24039.36 & P49 & 23058.93 \\
\hline N14 & 31234.53 & P09 & 22527.44 & P50 & 19393.28 \\
\hline N15 & 32133.50 & $\mathrm{P} 10$ & 23216.63 & P51 & 23098.32 \\
\hline N16 & 28983.91 & P11 & 18747.10 & P52 & 18755.48 \\
\hline N17 & 31189.20 & $\mathrm{P} 12$ & 23058.35 & P53 & 18671.76 \\
\hline N18 & 26962.14 & $\mathrm{P} 13$ & 21170.84 & P54 & 22473.72 \\
\hline N19 & 27450.28 & P14 & 14477.76 & P55 & 13701.58 \\
\hline $\mathrm{N} 20$ & 30195.02 & P15 & 23046.13 & P56 & 23952.18 \\
\hline $\mathrm{N} 21$ & 31157.55 & P16 & 14721.86 & P57 & 23190.65 \\
\hline $\mathrm{N} 22$ & 28608.63 & P17 & 21463.13 & P58 & 23781.21 \\
\hline $\mathrm{N} 23$ & 30181.72 & P18 & 18554.67 & P59 & 18859.13 \\
\hline $\mathrm{N} 24$ & 34314.05 & P19 & 22893.55 & P60 & 23395.62 \\
\hline $\mathrm{N} 25$ & 31978.07 & $\mathrm{P} 20$ & 13151.23 & P61 & 13220.31 \\
\hline N26 & 34671.84 & $\mathrm{P} 21$ & 19463.08 & P62 & 22818.84 \\
\hline $\mathrm{N} 27$ & 31012.63 & $\mathrm{P} 22$ & 23213.02 & P63 & 13519.25 \\
\hline $\mathrm{N} 28$ & 31323.14 & $\mathrm{P} 23$ & 14608.13 & P64 & 20986.34 \\
\hline $\mathrm{N} 29$ & 31285.50 & $\mathrm{P} 24$ & 13237.36 & P65 & 23738.82 \\
\hline N30 & 28535.38 & $\mathrm{P} 25$ & 23582.14 & P66 & 23697.95 \\
\hline
\end{tabular}


Table A.1. (continued)

\begin{tabular}{ll|ll|ll}
\hline Assembly & $\begin{array}{c}\text { Burnup, } \\
\text { (MWd/MTU) }\end{array}$ & Assembly & $\begin{array}{c}\text { Burnup, } \\
\text { (MWd/MTU) }\end{array}$ & Assembly & $\begin{array}{c}\text { Burnup, } \\
\text { (MWd/MTU) }\end{array}$ \\
\hline P67 & 19450.90 & R23 & 9540.92 & R46 & 10030.23 \\
P68 & 21087.32 & R24 & 9496.20 & R47 & 8099.91 \\
R01 & 9586.54 & R25 & 9963.45 & R48 & 10130.89 \\
R02 & 9887.52 & R26 & 8097.04 & R49 & 10065.96 \\
R03 & 7173.81 & R27 & 7305.21 & R50 & 9763.38 \\
R04 & 9966.34 & R28 & 7246.30 & R51 & 10089.86 \\
R05 & 7171.60 & R29 & 8971.77 & R52 & 9853.37 \\
R06 & 8191.27 & R30 & 9285.65 & R53 & 9801.75 \\
R07 & 7433.94 & R31 & 7414.78 & R54 & 10116.01 \\
R08 & 8860.19 & R32 & 8170.96 & R55 & 10181.53 \\
R09 & 9378.10 & R33 & 9563.64 & R56 & 10117.24 \\
R10 & 9973.42 & R34 & 9898.35 & R57 & 10139.73 \\
R11 & 8187.45 & R35 & 8849.43 & R58 & 8038.00 \\
R12 & 7263.07 & R36 & 9684.70 & R59 & 10121.54 \\
R13 & 8309.52 & R37 & 9949.55 & R60 & 10137.20 \\
R14 & 7441.79 & R38 & 9013.34 & R61 & 7343.88 \\
R15 & 8095.25 & R39 & 9955.53 & R62 & 7305.68 \\
R16 & 9276.32 & R40 & 9887.93 & R63 & 7467.84 \\
R17 & 9385.01 & R41 & 10084.14 & R64 & 9823.81 \\
R18 & 8110.23 & R42 & 10145.03 & R65 & 7348.38 \\
R19 & 9415.90 & R43 & 8044.55 & R66 & 9674.22 \\
R20 & 8936.58 & R44 & 8056.49 & R67 & 9835.56 \\
R21 & 8960.10 & R45 & 9731.26 & R68 & 9688.21 \\
R22 & 8256.64 & & & & \\
\hline & & & & &
\end{tabular}


Table A.2. Sequoyah Unit 2 operating history for Cycles 1 and 2 and to Cycle 3 mid-cycle restart

Cycle times, days

\begin{tabular}{lccccc} 
Cycle & Startup & Shutdown & Up & Down & Total \\
\hline 1 & $6 / 1 / 82$ & $7 / 17 / 83$ & 412 & 165 & 577 \\
2 & $1 / 1 / 84$ & $9 / 28 / 84$ & 272 & 153 & 425 \\
$3 \mathrm{~A}^{a}$ & $3 / 1 / 85$ & $8 / 21 / 85$ & 205 & 0 & 205 \\
\hline
\end{tabular}

${ }^{a}$ Cycle 3 history split at the long 997-day shutdown. Cycle 3B startup date was 5/14/88. 


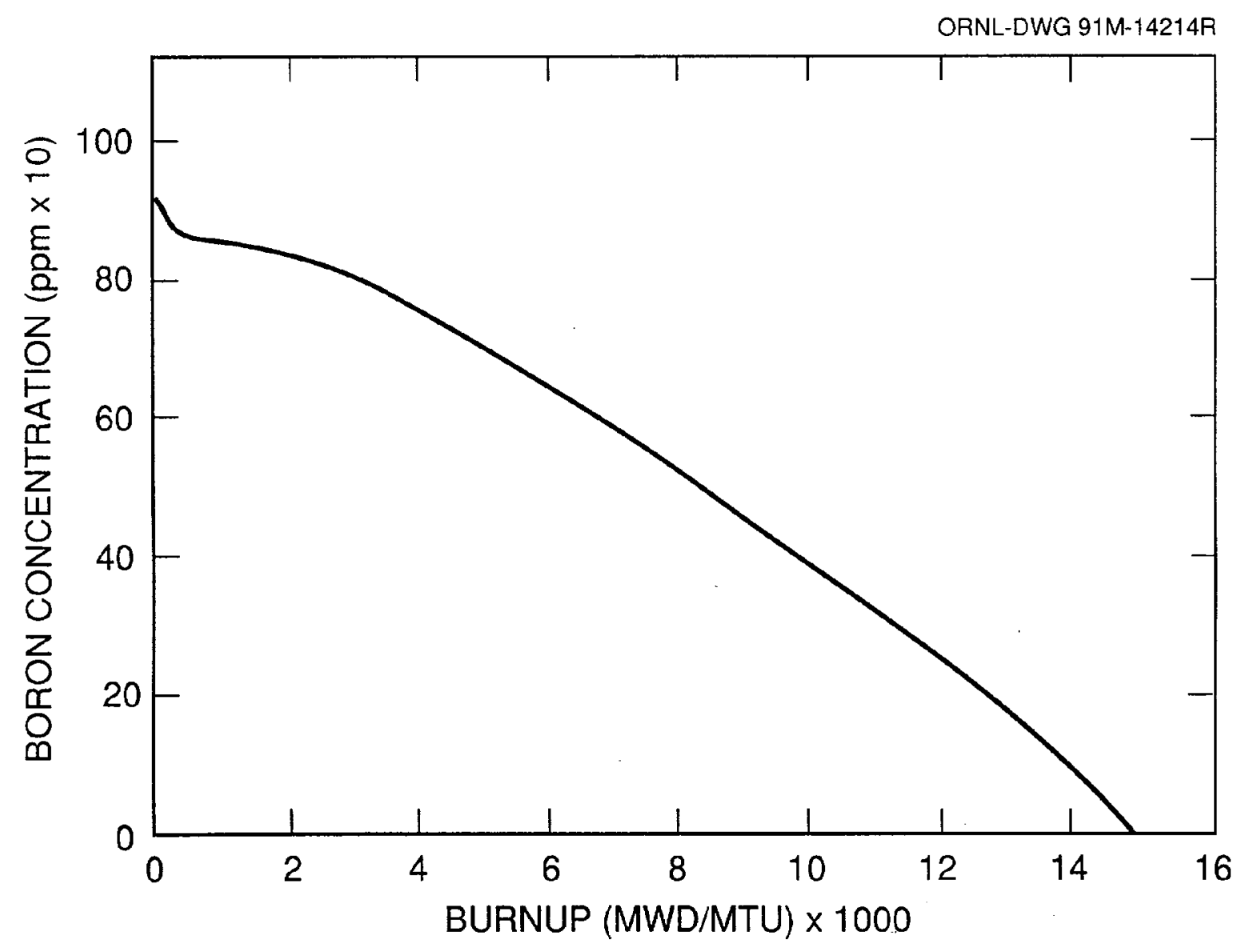

Fig. A.1. Sequoyah Unit 2, Cycle 1, boron letdown curve. 


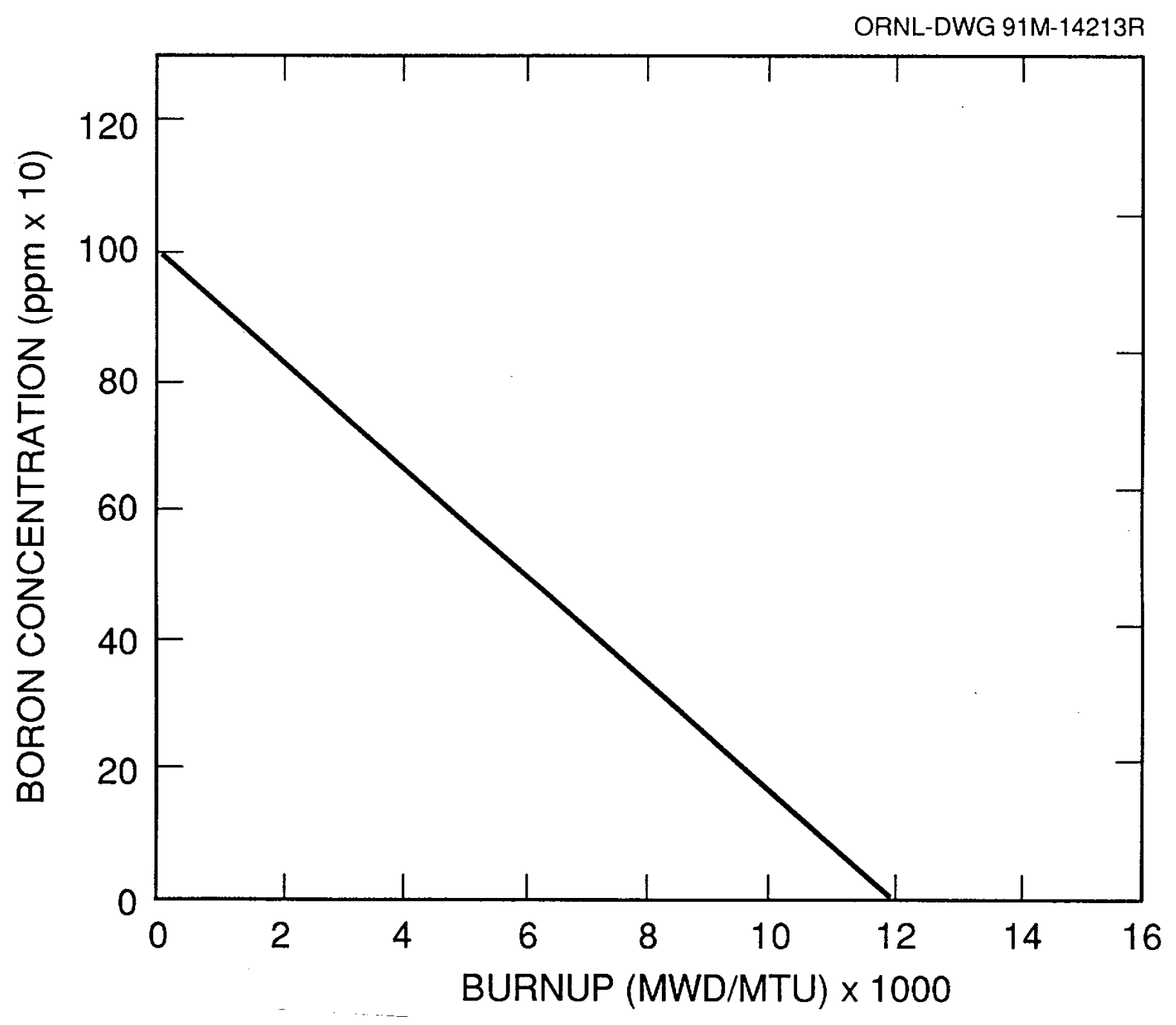

Fig. A.2. Sequoyah Unit 2, Cycle 2, normalized boron letdown curve. 


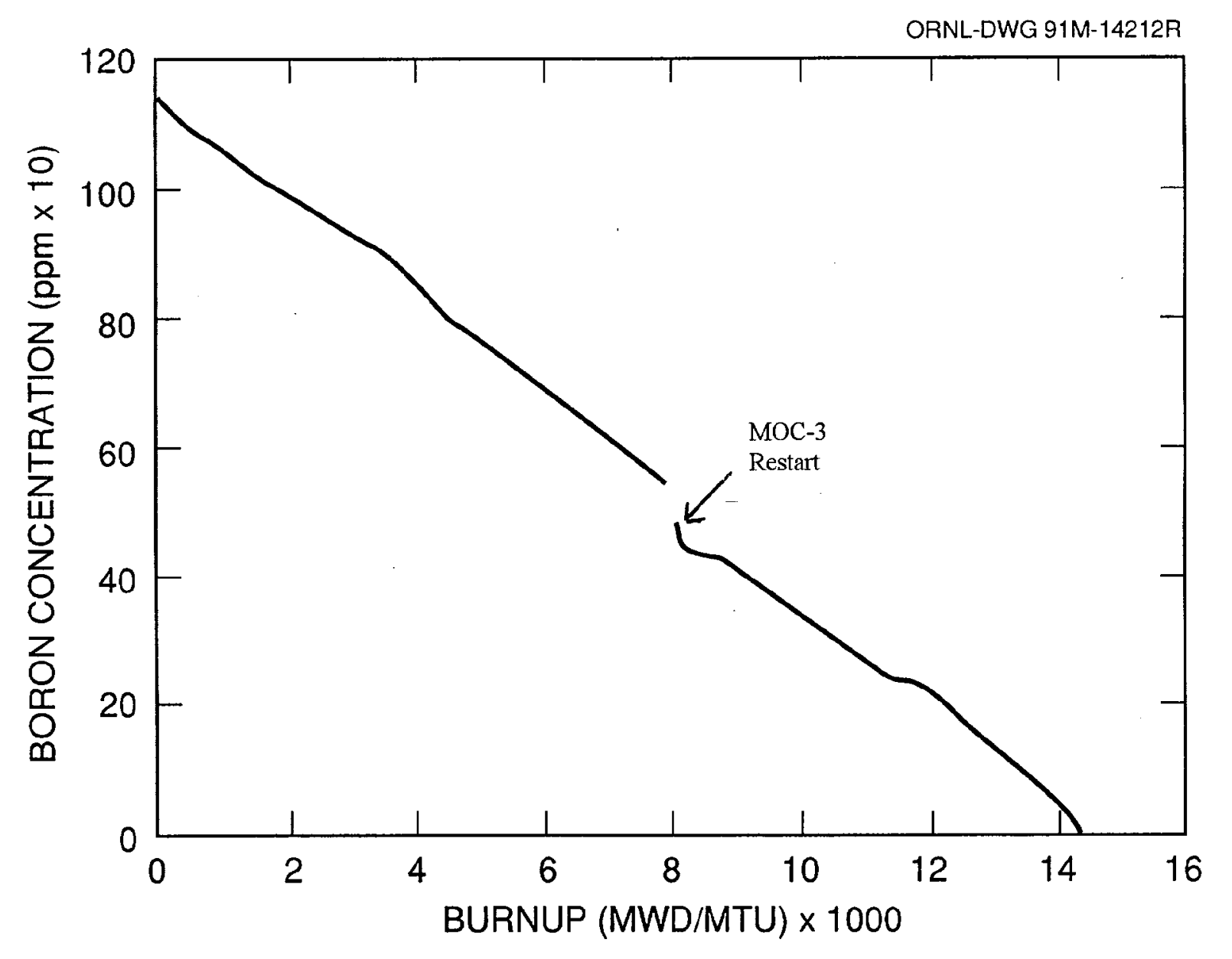

Fig. A.3. Sequoyah Unit 2, Cycle 3, boron letdown curve. 
ORNL-DWG $91 \mathrm{M}-14215$

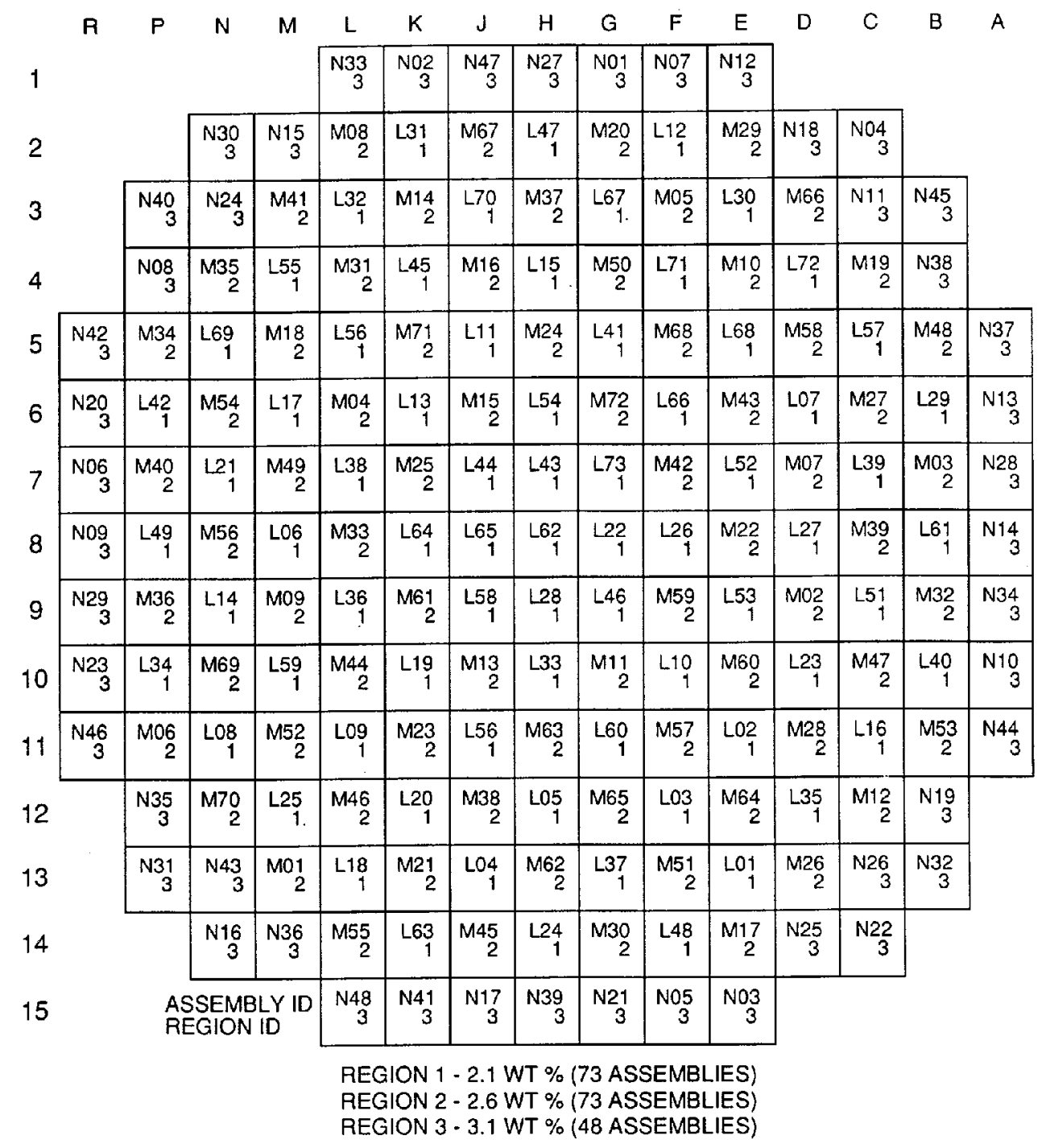

Fig. A.4. Sequoyah Unit 2, Cycle 1, initial core loading pattern. 
ORNL-DWG 91M-14216

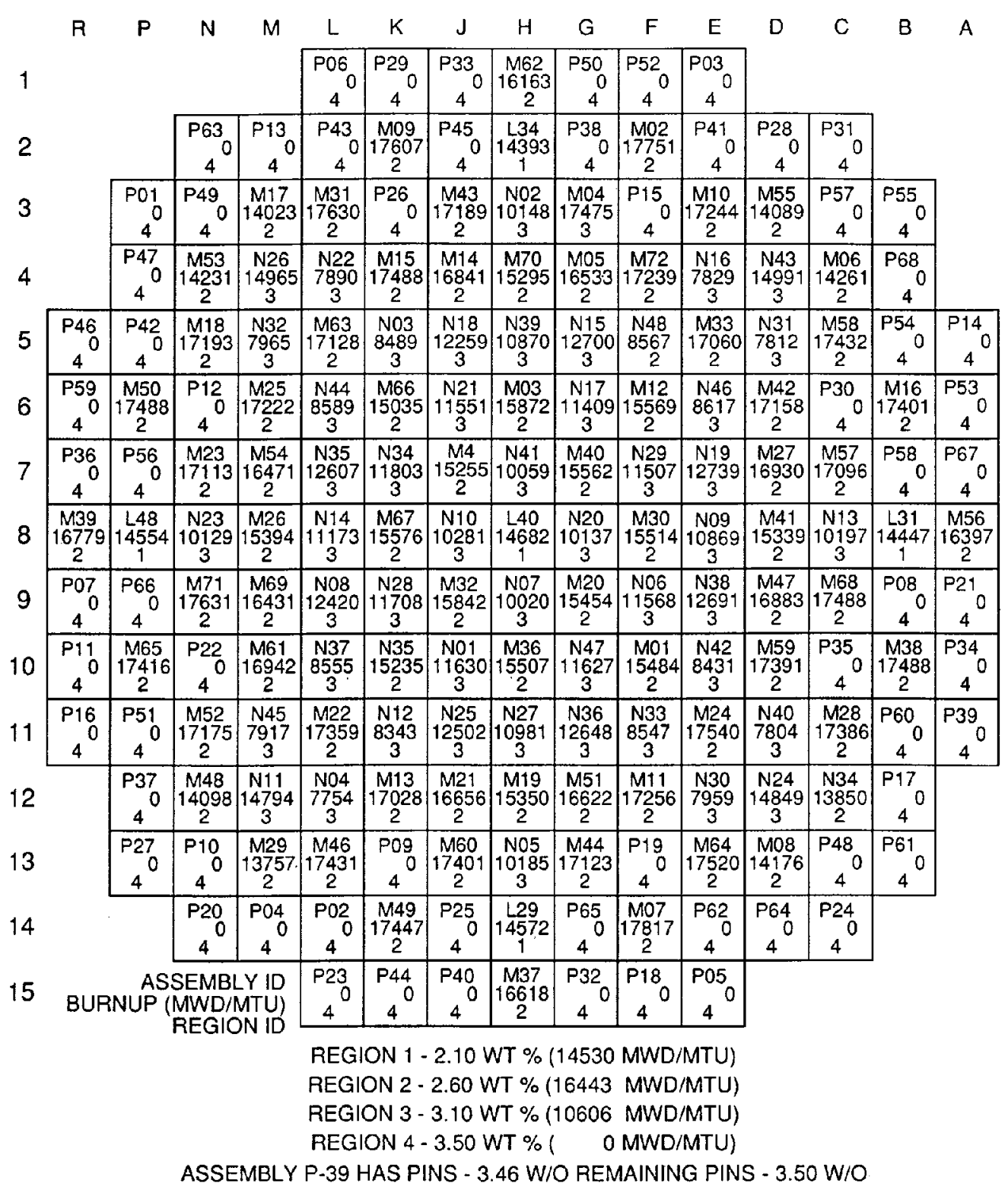

Fig. A.5. Sequoyah Unit 2, Cycle 2, initial core loading pattern. 
ORNL-DWG $91 M-14217$

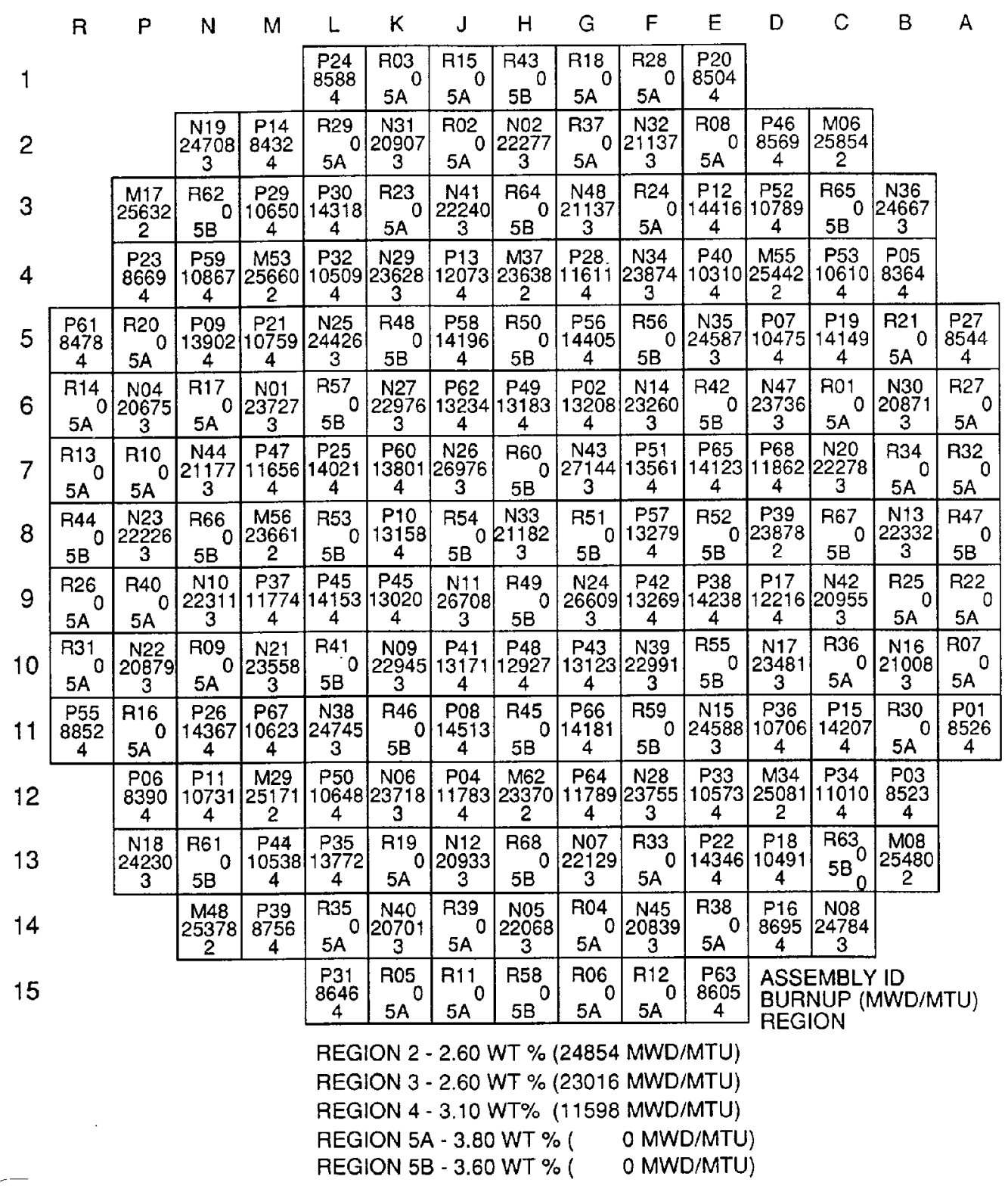

ASSEMBLY P-39 HAS 19 PINS - 3.4 W/O REMAINING PINS - 3.50 W/O

Fig. A.6. Sequoyah Unit 2, Cycle 3, initial core loading pattern. 
ORNL-DWG 91M-14218

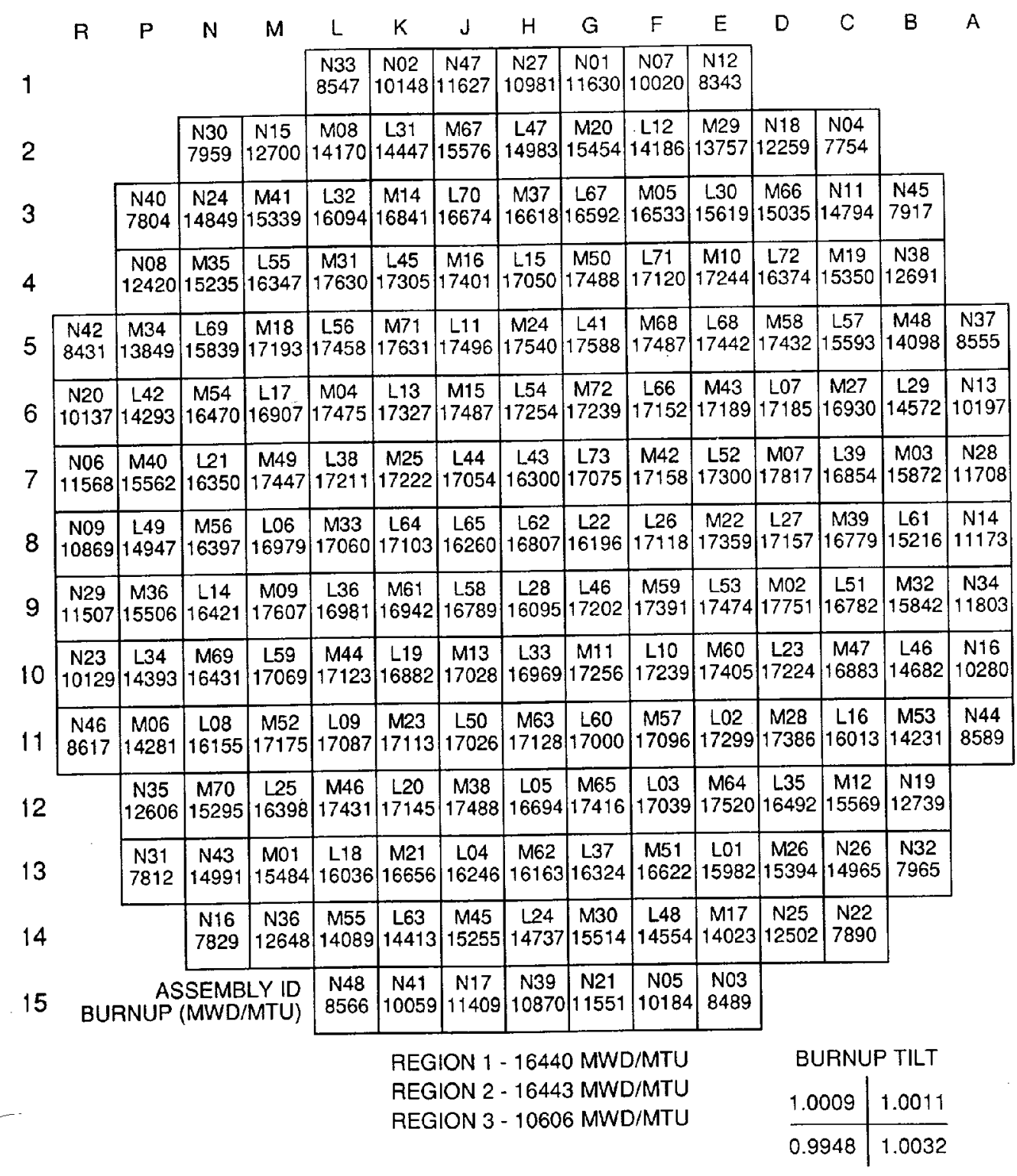

Fig. A.7. Sequoyah Unit 2, Cycle 1, final burnup distribution. 
ORNL-DWG 91M-14219

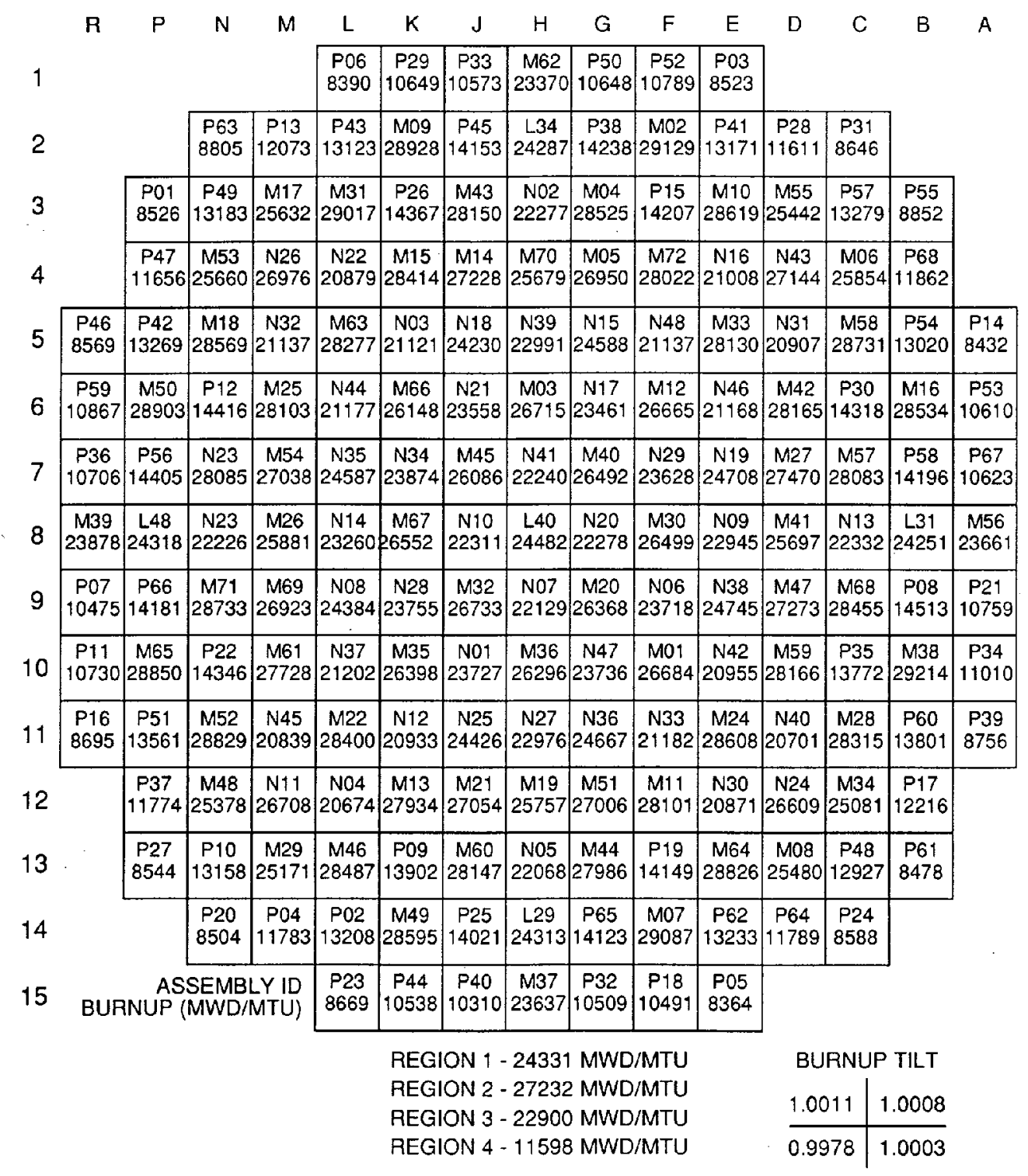

Fig. A.8. Sequoyah Unit 2, Cycle 2, final burnup distribution. 


\section{APPENDIX B}

\section{SAS2H CASE INPUT EXAMPLE}

This appendix gives an example of one of the seven SAS2H cases. It gives a list of the JCL and data for SAS2H batch No. 7. 


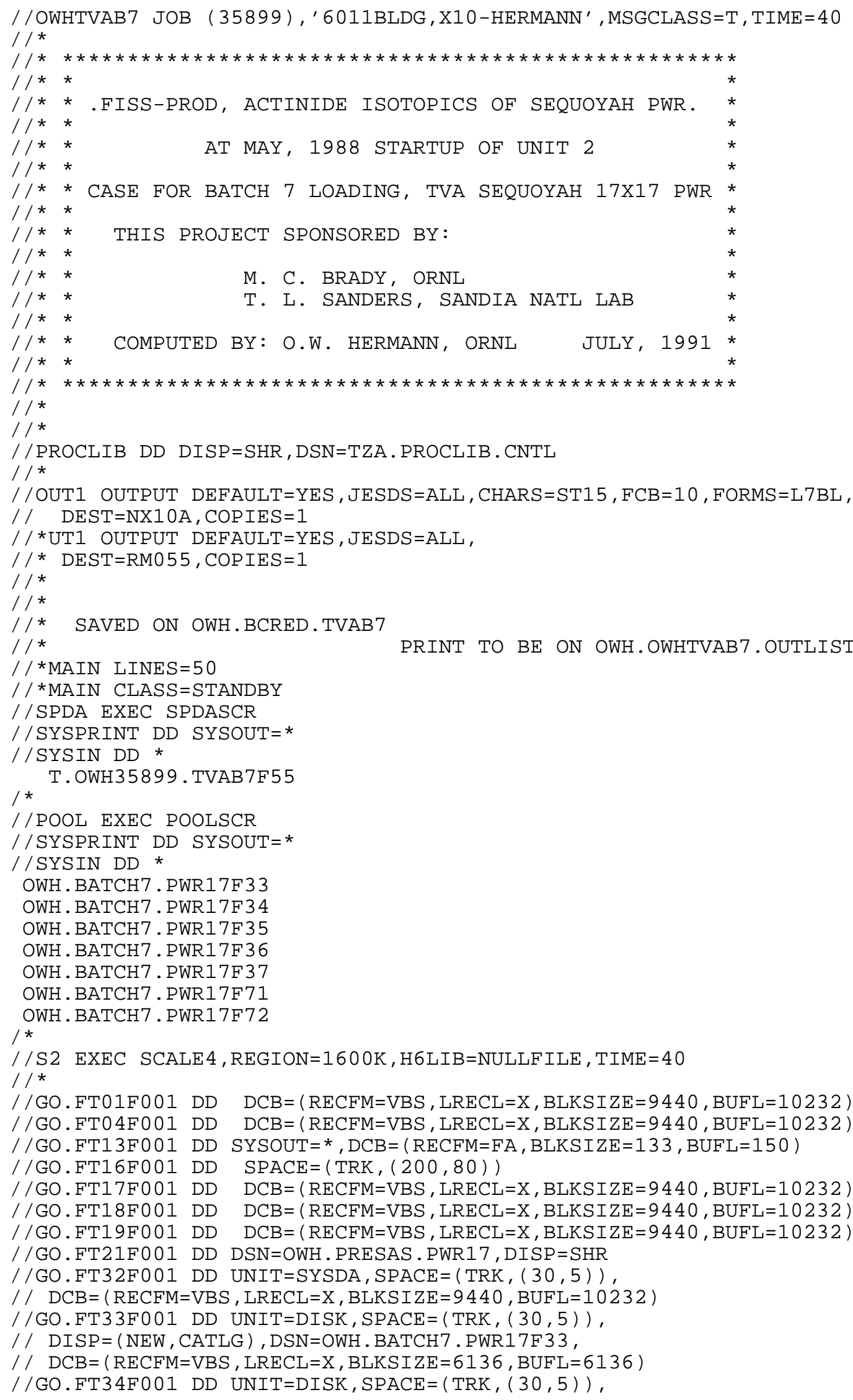


/ / $\mathrm{DISP}=(\mathrm{NEW}, \mathrm{CATLG}), \mathrm{DSN}=\mathrm{OWH} . \mathrm{BATCH} 7 . \mathrm{PWR} 17 \mathrm{~F} 34$,

/ / $\mathrm{DCB}=(\mathrm{RECFM}=\mathrm{VBS}, \mathrm{LRECL}=\mathrm{X}, \mathrm{BLKSIZE}=6136, \mathrm{BUFL}=6136)$

//GO.FT35F001 DD UNIT=DISK, $\operatorname{SPACE}=(\operatorname{TRK},(30,5))$,

// $\mathrm{DISP}=(\mathrm{NEW}, \mathrm{CATLG}), \mathrm{DSN}=\mathrm{OWH} . \mathrm{BATCH} 7 . \mathrm{PWR} 17 \mathrm{~F} 35$,

/ / $\mathrm{DCB}=(\mathrm{RECFM}=\mathrm{VBS}, \mathrm{LRECL}=\mathrm{X}, \mathrm{BLKSIZE}=6136, \mathrm{BUFL}=6136)$

//GO.FT36F001 DD UNIT=DISK, $\operatorname{SPACE}=(\operatorname{TRK},(30,5))$,

// $\mathrm{DISP}=(\mathrm{NEW}, \mathrm{CATLG}), \mathrm{DSN}=\mathrm{OWH} . \mathrm{BATCH} 7 . \mathrm{PWR} 17 \mathrm{~F} 36$,

$/ / \mathrm{DCB}=(\mathrm{RECFM}=\mathrm{VBS}, \mathrm{LRECL}=\mathrm{X}, \mathrm{BLKSIZE}=6136, \mathrm{BUFL}=6136)$

//GO.FT37F001 DD UNIT=DISK, SPACE= (TRK, $(30,5))$,

// DISP $=(\mathrm{NEW}, \mathrm{CATLG}), \mathrm{DSN}=\mathrm{OWH} . \mathrm{BATCH} 7 . \mathrm{PWR} 17 \mathrm{~F} 37$,

/ / $\mathrm{DCB}=(\mathrm{RECFM}=\mathrm{VBS}, \mathrm{LRECL}=\mathrm{X}, \mathrm{BLKSIZE}=6136, \mathrm{BUFL}=6136)$

/ /* NOTE ABOVE BLOCKSIZE/BUFL CHANGED TO SCALE DEFAULT.....

//GO.FT70F001 DD SPACE $=(\operatorname{TRK},(10,8)), \mathrm{UNIT}=\operatorname{SYSDA}$,

/ / $\mathrm{DCB}=(\mathrm{RECFM}=\mathrm{VBS}, \mathrm{LRECL}=\mathrm{X}, \mathrm{BLKSIZE}=9440, \mathrm{BUFL}=10232)$

$/ /$ GO.FT71F001 DD UNIT=DISK, $\operatorname{SPACE}=(\operatorname{TRK},(20,5))$,

$/ / \mathrm{DISP}=(\mathrm{NEW}, \mathrm{CATLG}), \mathrm{DSN}=\mathrm{OWH} . \mathrm{BATCH} 7 . \mathrm{PWR} 17 \mathrm{~F} 71$,

// $\mathrm{DCB}=(\mathrm{RECFM}=\mathrm{VBS}, \mathrm{LRECL}=\mathrm{X}, \mathrm{BLKSIZE}=9440, \mathrm{BUFL}=10232)$

$/ /$ GO.FT72F001 DD UNIT=DISK, SPACE $=(\operatorname{TRK},(10,5))$,

/ / $\mathrm{DCB}=(\mathrm{RECFM}=\mathrm{FB}, \mathrm{LRECL}=80, \mathrm{BLKSIZE}=6400)$,

$/ / \mathrm{DISP}=(\mathrm{NEW}, \mathrm{CATLG}), \mathrm{DSN}=\mathrm{OWH} . \mathrm{BATCH} 7 . \mathrm{PWR} 17 \mathrm{~F} 72$

$/ /$ GO.FT74F001 DD UNIT=SYSDA,

// $\operatorname{SPACE}=(800,(2,2), \mathrm{RLSE}), \mathrm{DCB}=(\mathrm{RECFM}=\mathrm{FB}, \mathrm{LRECL}=80, \mathrm{BLKSIZE}=800)$

//GO.FT53F001 DD UNIT=SYSDA, $\operatorname{SPACE}=(\operatorname{TRK},(90,5))$,

/ / $\mathrm{DCB}=(\mathrm{RECFM}=\mathrm{VBS}, \mathrm{LRECL}=\mathrm{X}, \mathrm{BLKSIZE}=3664, \mathrm{BUFL}=4088)$

//GO.FT55F001 DD UNIT=SPDA, SPACE= $(\operatorname{TRK},(2,1))$,

// $\mathrm{DCB}=(\mathrm{RECFM}=\mathrm{VBS}, \mathrm{LRECL}=\mathrm{X}, \mathrm{BLKSIZE}=3664, \mathrm{BUFL}=4088)$,

$/ / \mathrm{DISP}=(\mathrm{NEW}, \mathrm{CATLG}), \mathrm{DSN}=\mathrm{T} . \mathrm{OWH} 35899 . \mathrm{TVAB} 7 \mathrm{~F} 55$

$/ /$ GO.SYSIN DD *

=SAS2 PARM=' HALT05, SKIPSHIPDATA'

SAS2H: TVA, SQN UNIT 2, CYC 3, BATCH 7, BURNUP CREDIT CRITICAL CHECK 27BURNUPLIB LATTICECELL

,

, MIXTURES OF FUEL-PIN-UNIT-CELL:

$\begin{array}{lllllllllllll}\text { UO2 } & 1 & 0.9485 & 901 & 92234 & 0.031 & 92235 & 3.60 & 92236 & 0.017 & 92238 & 96.352 & \text { END }\end{array}$

$\begin{array}{lllllll}\mathrm{KR}-83 & 1 & 0 & 1-20 & 901 & \mathrm{END}\end{array}$

$\begin{array}{lllllll}\mathrm{KR}-85 & 1 & 0 & 1-20 & 901 & \mathrm{END}\end{array}$

$\begin{array}{lllllll}\mathrm{SR}-90 & 1 & 0 & 1-20 & 901 & \mathrm{END}\end{array}$

$\begin{array}{lllllll}Y-89 & 1 & 0 & 1-20 & 901 & \text { END }\end{array}$

MO-95 $11001-20 \quad 901 \quad$ END

ZR-93 $1101-20 \quad 901 \quad$ END

$\begin{array}{llllll}Z R-94 & 1 & 0 & 1-20 & 901 & \text { END }\end{array}$

ZR-95 $1101-20 \quad 901 \quad$ END

$\begin{array}{llllll}\text { NB-94 } & 1 & 0 & 1-20 & 901 & \text { END }\end{array}$

$\begin{array}{llllll}\text { TC-99 } & 1 & 0 & 1-20 & 901 & \text { END }\end{array}$

RH-103 $11001-20 \quad 901 \quad$ END

RH-105 $1001-20 \quad 901 \quad$ END

RU-101 $1001-20 \quad 901 \quad$ END

RU-106 $1001-20 \quad 901 \quad$ END

$\begin{array}{llllll}\mathrm{PD}-105 & 1 & 0 & 1-20 & 901 & \mathrm{END}\end{array}$

$\mathrm{PD}-108 \quad 1 \quad 0 \quad 1-20 \quad 901 \quad \mathrm{END}$

AG-109 $1001-20 \quad 901$ END

SB-124 $1001-20 \quad 901 \quad$ END

$\mathrm{XE}-131 \quad 1 \quad 0 \quad 1-20 \quad 901 \quad \mathrm{END}$

$\mathrm{XE}-132 \quad 1 \quad 0 \quad 1-20 \quad 901 \quad \mathrm{END}$

$\begin{array}{llllll}\mathrm{XE}-135 & 1 & 0 & 1.2-8 & 901 & \mathrm{END}\end{array}$

$\begin{array}{llllll}\mathrm{XE}-136 & 1 & 0 & 1-20 & 901 & \mathrm{END}\end{array}$

CS-134 $1001-20 \quad 901 \quad$ END

CS-135 $1001-20 \quad 901 \quad$ END

CS-137 $1001-20 \quad 901 \quad$ END 


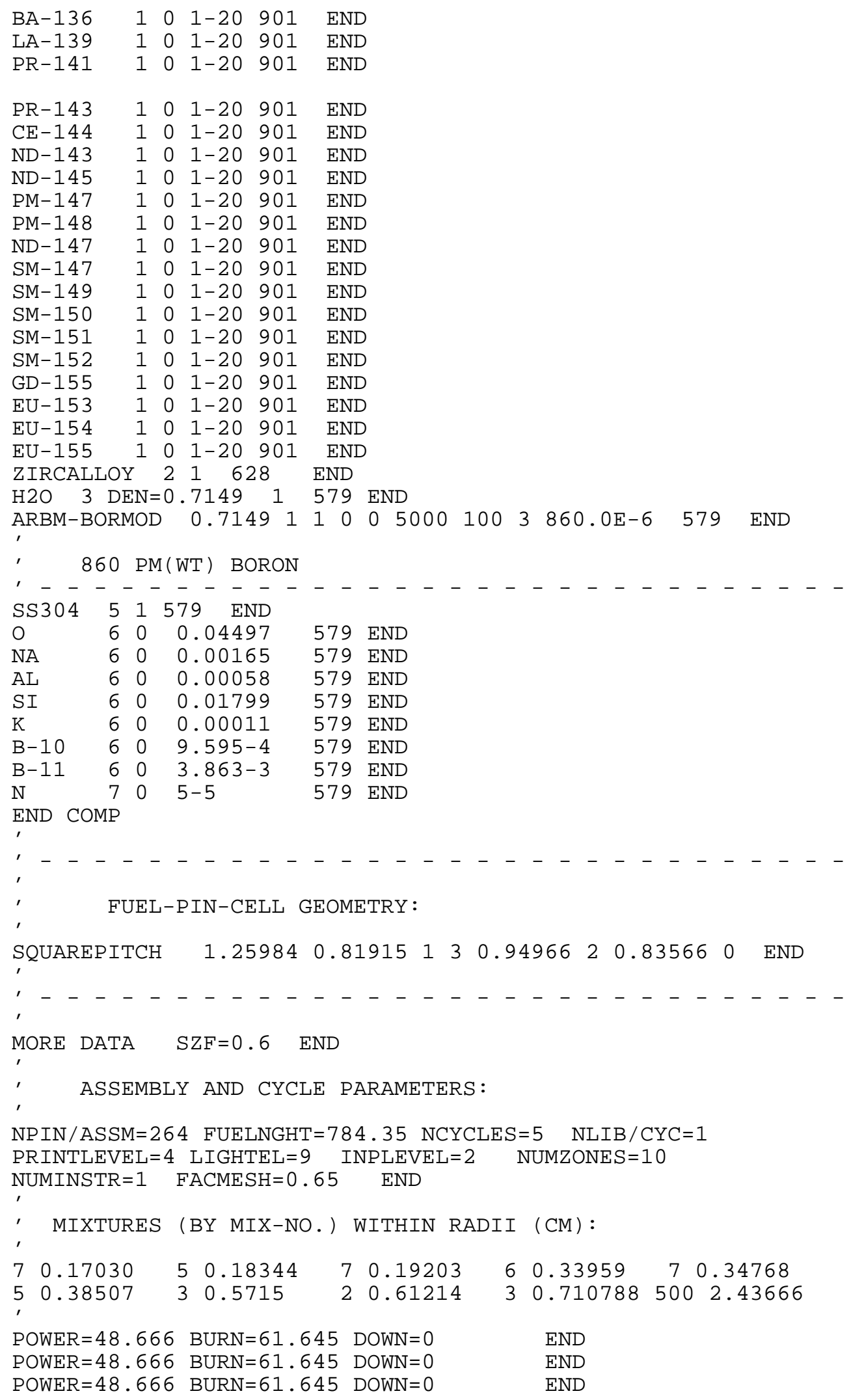




\section{5}

$\mathrm{POWER}=48.666 \mathrm{BURN}=61.645 \mathrm{DOWN}=0$

END

$\mathrm{POWER}=48.666 \mathrm{BURN}=61.645 \mathrm{DOWN}=0$

END

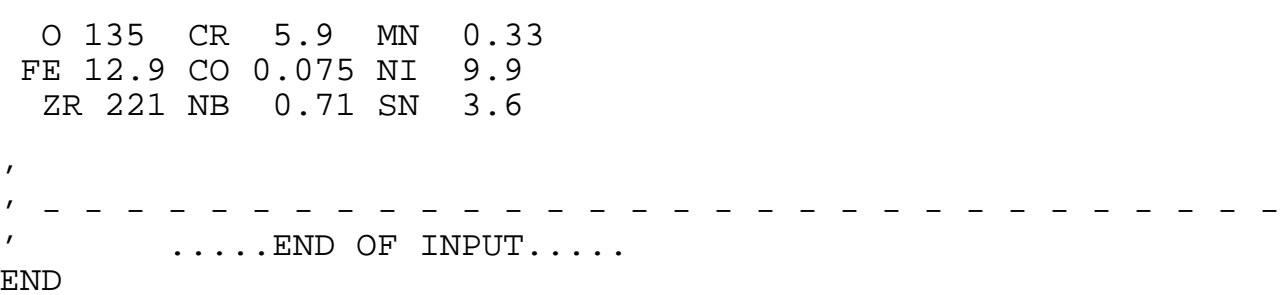




\section{APPENDIX C \\ SNIKR VERSION 1.0 DOCUMENTATION}

This appendix includes a User's Input Guide, FORTRAN Listings, and Sample Output. 


\section{SNIKR VERSION 1.0 USER'S INPUT GUIDE}

Each entry below must begin in column 1. Recommended values are given in parentheses.

Line $1 \quad$ SNIKR1

Line 2 Title card for SNIKR1 (80-character maximum)

Line 3 READ BURNUP

Line $4 \quad$ N72=ii (I2 format)

Unit number for SAS2H atom density file (72)

Line $5 \quad$ NOUT=ii (I2 format)

Unit number for SNIKR1 output file (70)

Line $6 \quad$ BURN=xxxxxx.x (F8.1 format)

Desired burnup in MWd/MTU for interpolation

Line $7 \quad \mathrm{NCYC}=\mathrm{ii} \quad$ (I2 format)

Number of cycles in SAS2H depletion

Line $8 \quad$ END BURNUP

Line 9 READ DECAY

Line $10 \quad$ NORS=ii (I2 format)

Unit number for ORIGEN-S input file created by SNIKR1 (74)

Line $11 \quad$ N71=ii (I2 format)

Unit number to which ORIGEN-S will write the restart file containing the isotopic data at the requested cooling times. This file will then be read by SNIKR3 (71)

Line 12 COOLTME=xxx.xx (F6.2 format)

Cooling time in years at which isotopics are desired

Line 13 LIGHTEL=ii (I2 format)

Number of light element nuclides for which isotopics are desired. Data will be read after "END DECAY." This option allows the user to extract light-element data in addition to actinide and fission-product data and/or to adjust the concentrations of light-element nuclides.

Line $14 \quad$ END DECAY 
If LIGHTEL > 0, enter the following data for each light-element nuclide (free format):

a. Nuclide ID number

b. Atom density of nuclide

c. Option flag

$1=$ replace SAS2H atom density with value entered above

$2=$ replace SAS2H atom density only if SAS2H value is zero

$3=$ add the atom density to the SAS2H value. Using this option and an atom density of zero above will extract data from SAS2H without modification.

\section{Line $15 \quad$ SNIKR3}

Line 16 Title card for SNIKR3 (80-character maximum)

Line $17 \quad$ READ MXFUEL

Line $18 \quad$ N71=ii (I2 format)

Unit number from which SNIKR3 will read the ORIGEN-S restart file containing the isotopic data at the requested cooling times (71)

Line 19 NICE=ii (I2 format)

Unit number to which SNIKR3 writes the data for input to ICE (75)

Line $20 \quad$ NOUT3=ii (I2 format)

Unit number to which SNIKR3 writes the data in SCALE standard composition and KENO V.a mixing table input formats (73)

Line $21 \quad$ NCOOL=ii (I2 format)

Cooling time step in ORIGEN-S output from which isotopic data are to be extracted

Line 22 FISPROD=iii (I3 format)

Actinide and fission-product nuclides for which isotopic data are to be extracted

$0=25$ burnup credit nuclides from ref. 4

$-1=37$ burnup credit nuclides from ref. 1

$-2=48$ nuclides used in reactor critical calculations (Table 2)

$-3=193$ nuclides (all nuclides in 27-group burnup library)

$\mathrm{N}=\quad$ Read N nuclides specified by user after "END MXFUEL"

Line 23 MIXF=iiii (I4 format)

Mixture number for SCALE standard composition input

Line 24 IDMOD=ii (I2 format)

Fuel nuclide ID modifier for seven burnup-dependent actinides 


\section{Line $25 \quad$ END MXFUEL}

If FISPROD > 0, enter the nuclide IDs here. (Format 10(1X,I5)) 


\section{SNIKR1 FORTRAN Listing}

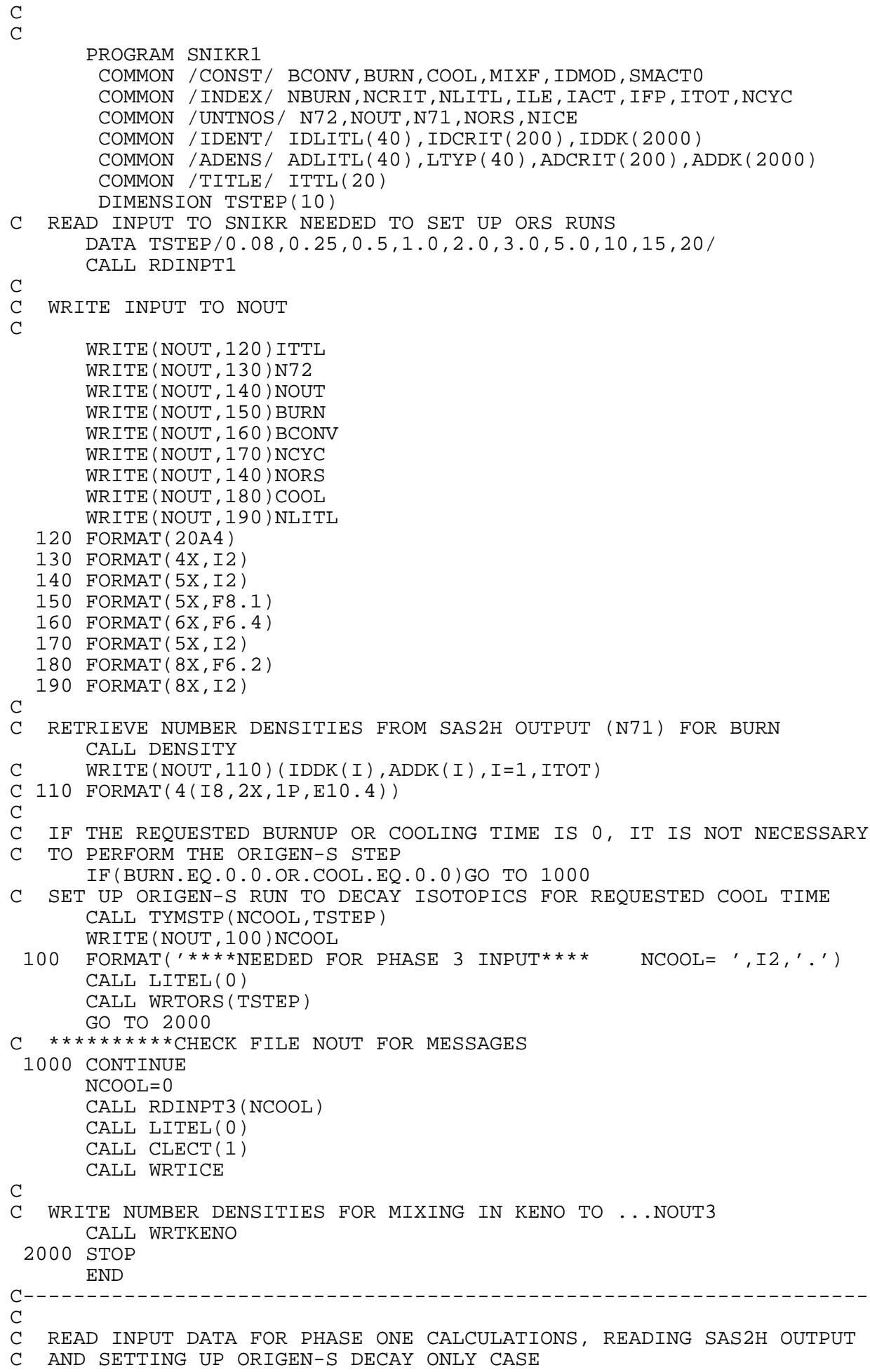


C

SUBROUTINE RDINPT1

COMMON /CONST / BCONV, BURN, COOL, MIXF, IDMOD, SMACTO

COMMON / INDEX/ NBURN, NCRIT, NLITL, ILE, IACT, IFP, ITOT, NCYC

COMMON /UNTNOS/ N72, NOUT, N71, NORS, NICE

COMMON /IDENT/ IDLITL(40), IDCRIT (200), IDDK (2000)

COMMON /ADENS/ ADLITL(40), LTYP (40), ADCRIT (200), ADDK (2000)

COMMON /TITLE/ ITTL (20)

CHARACTER $* 6$ ICHK

$\mathrm{N} 5=5$

READ (N5, 110) ICHK

C READ AND CHECK IF APPROPRIATE PHASE INPUT - SNIKR1

IF (ICHK.NE.' SNIKR1') STOP 5101

C READ TITLE CARD

READ (N5, 120) ITTL

C READ LABEL AND CHECK TO BE SURE BURN DATA IS NEXT READ (N5, 110) ICHK

IF (ICHK. NE.' READ B') STOP 5102

C READ N72, UNIT NUMBER FOR SAS2H FILE 72 OUTPUT TO BE READ FROM READ (N5, 130) N72

C READ NOUT, UNIT NUMBER FOR OUTPUT TO BE WRITTEN TO READ (N5, 140) NOUT

C READ BURNUP IN MWD/MTU THAT NUMBER DENSITIES ARE TO BE RETRIEVED FROM N72 READ (N5, 150) BURN

C READ METAL (MTU/ASSEMBLY), BCONV IS CONVERSION FACTOR FOR BURNUPS

C READ FROM N72

READ (N5, 160) BCONV

$\star \star \star \star$ MODIFIED SNIKR, NOW READ FROM SAS2H OUTPUT

READ NCYC, NUMBER OF BURN CYCLES USED TO PRODUCE SAS2H OUTPUT ON N72 READ (N5, 170) NCYC

C READ AND CHECK THAT THIS IS END OF BURNUP DATA READ (N5, 110) ICHK IF (ICHK.NE.' END BU') STOP 5103

C READ AND CHECK THAT DECAY DATA BEGINS WITH NEXT CARD READ (N5, 110) ICHK IF (ICHK.NE.' READ D') STOP 5104

C READ NORS, UNIT NUMBER FOR ORIGEN-S INPUT TO BE WRITTEN READ (N5, 140) NORS

C READ N71, UNIT NUMBER FOR ORIGEN-S OUTPUT TO BE WRITTEN FOR PHASE 3 READ (N5, 130) N71

C READ COOLING TIME IN YEARS TO BE USED TO SET UP ORIGEN-S DECAY CASE READ (N5, 180) COOL

C READ THE NUMBER OF LIGHT ELEMENTS TO BE SPECIFIED IN THE DECAY CASE READ (N5, 190) NLITL

C READ AND CHECK THAT THIS IS THE END OF DECAY DATA READ (N5, 110) ICHK IF (ICHK.NE.' END DE') STOP 5105

C IF NLITL IS GREATER THAN ZERO READ IN ID'S OF LIGHT ELEMENTS IF (NLITL.EQ.O) GO TO 1000 $\operatorname{READ}(\mathrm{N} 5, *)(\operatorname{IDLITL}(\mathrm{I}), \operatorname{ADLITL}(\mathrm{I}), \operatorname{LTYP}(\mathrm{I}), \mathrm{I}=1, \operatorname{NLITL})$

1000 CONTINUE

C

WRITE INPUT TO NOUT

WRITE (NOUT, 120) ITTL

WRITE (NOUT, 130) N72

WRITE (NOUT, 140) NOUT

WRITE (NOUT, 150) BURN

WRITE (NOUT, 160) BCONV

WRITE (NOUT, 170) NCYC

WRI TE (NOUT, 140) NORS

WRITE (NOUT, 180) COOL

WRITE (NOUT, 190) NLITL RETURN

110 FORMAT (A6)

120 FORMAT (20A4) 


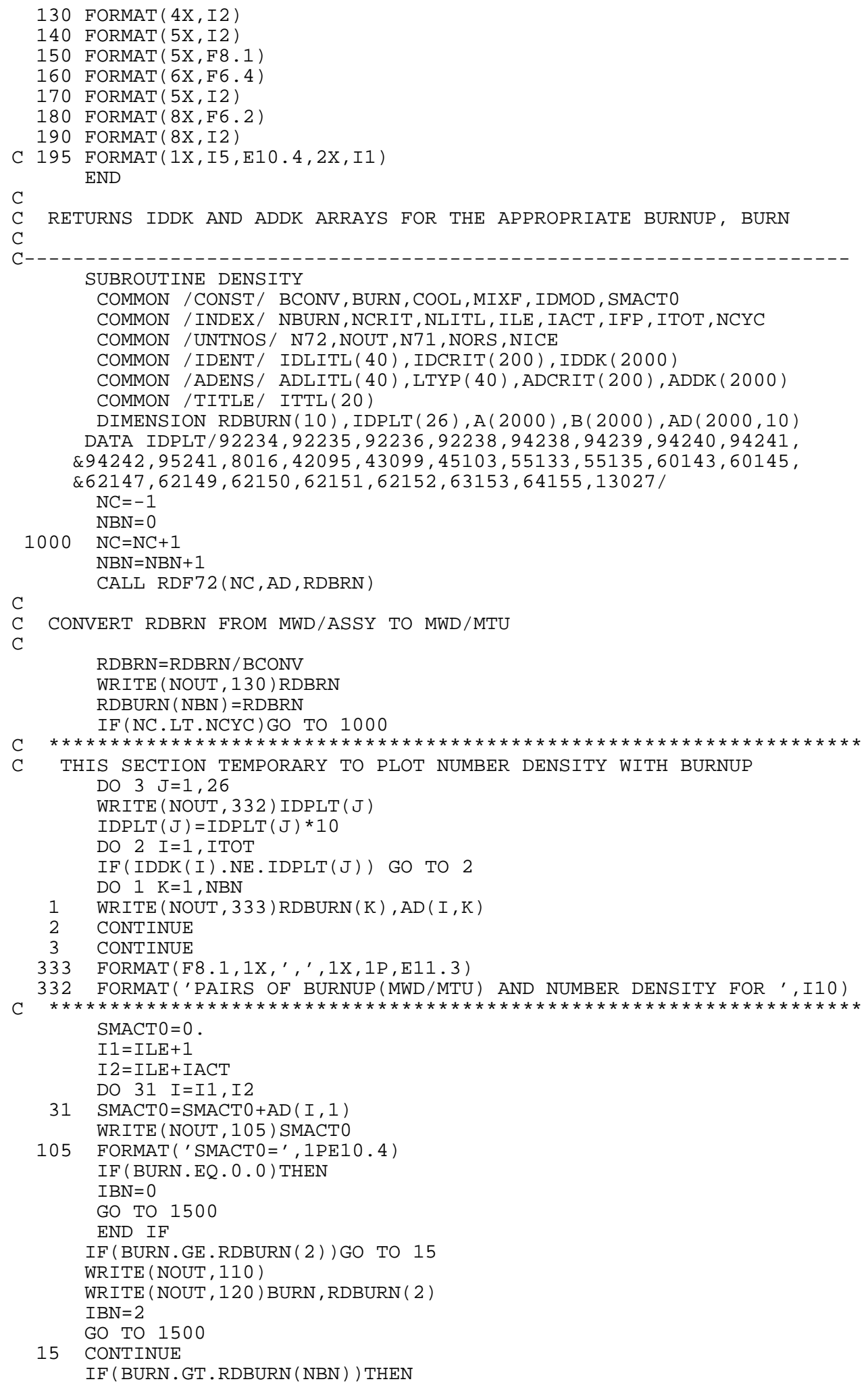




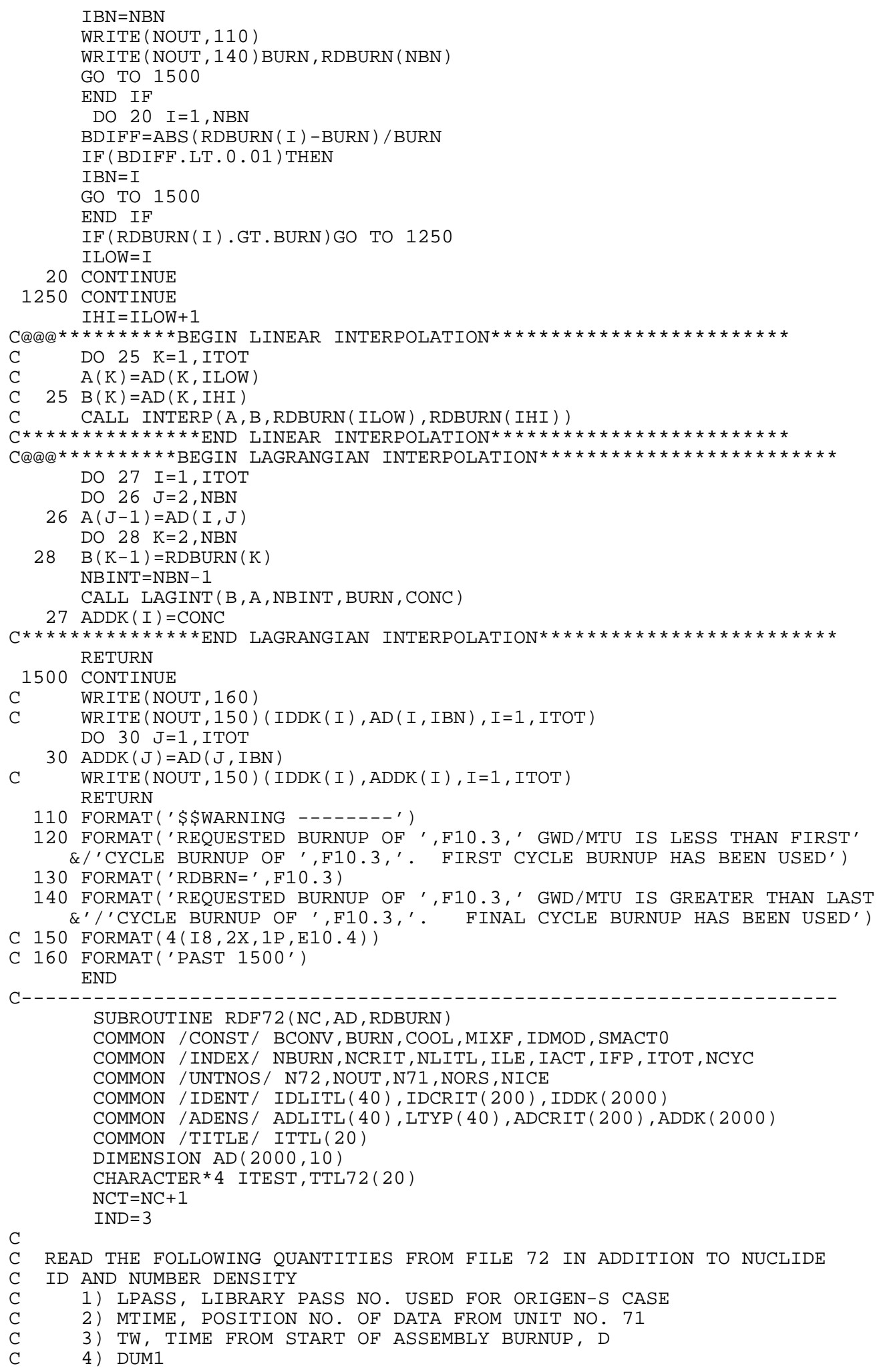


C 5) RDBURN, ACCUMULATED BURNUP AT TW, MWD/ASSEMBLY

C 6) SPWR, SPECIFIC POWER OF CYCLE, KW/KG U

7) DUM3

8) BCONV, INITIAL METRIC TON U WEIGHT PER ASSEMBLY

C

READ (N72,100, END=2000) LPASS, MT IME , TW, DUM1 , RDBURN, SPWR, DUM3, BCONV IF (NCT.EQ.1) WRITE (NOUT, 99)

99 FORMAT (/,

\&/'1) LPASS, LIBRARY PASS NO. USED FOR ORIGEN-S CASE',

$\& / \prime 2)$ MTIME, POSITION NO. OF DATA FROM UNIT NO. 71',

\&/'3) TW, TIME FROM START OF ASSEMBLY BURNUP, D',

$\& / \prime 4)$ DUM1',

$\& /$ '5) RDBURN, ACCUMULATED BURNUP AT TW, MWD/ASSEMBLY',

$\& /, 6)$ SPWR, SPECIFIC POWER OF CYCLE, KW/KG U',

$\& / \prime 7)$ DUM3',

\&/'8) BCONV, INITIAL METRIC TON U WEIGHT PER ASSEMBLY')

WRITE (NOUT, 100) LPASS, MTIME, TW, DUM1, RDBURN, SPWR, DUM3, BCONV

IF (LPASS.EQ.NCYC) IND $=1$

IF (LPASS.NE.NC) THEN

WRITE (NOUT, 101) NC, LPASS, NCYC

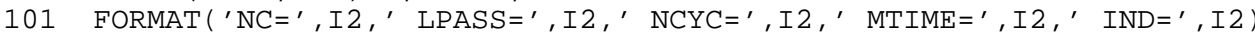

STOP 7210

END IF

IF (MTIME.NE. IND) THEN

WRITE (NOUT, 101) NC, LPASS, NCYC, MTIME, IND

IF (NC.EQ.NCYC.AND.MTIME.EQ.3) GO TO 5

STOP 7220

END IF

5 CONTINUE

READ (N72, 110) ITOT, ILE, IACT, IFP

ISUM=ILE+IACT+IFP

IF (ISUM.NE.ITOT) STOP 7230

DO $10 \quad I=1,4$

$10 \quad \operatorname{READ}(\mathrm{N} 72,140)$

$\operatorname{READ}(\mathrm{N} 72,120)(\operatorname{IDDK}(\mathrm{I}), \mathrm{AD}(\mathrm{I}, \mathrm{NCT}), \mathrm{I}=1, \mathrm{ITOT})$

C WRITE (NOUT, 102) NCT, LPASS, NCYC

C 102 FORMAT ('NCT=', I2,' LPASS=', I2,' $\mathrm{NCYC}={ }^{\prime}, \mathrm{I} 2$, ' AD ARRAY')

C WRITE (NOUT, 120) (IDDK (I), $\operatorname{AD}(I, N C T), I=I L E, I L E+16)$

READ (N72, 125) TTL72

WRITE (NOUT, 125) TTL72

C WRITE (NOUT, 160) RDBURN, NCT

1000 READ (N72,130) ITEST

IF (ITEST.NE.'---'') GO TO 1000

RETURN

2000 CONTINUE

WRITE (NOUT, 150)

RETURN

100 FORMAT $(2 \mathrm{I} 10,6(1 \mathrm{X}, 1 \mathrm{P}, \mathrm{E9} .3))$

110 FORMAT (4I10)

120 FORMAT (4 (I8, 2X, 1P, E10.4))

125 FORMAT (20A4)

130 FORMAT (A4)

140 FORMAT ( )

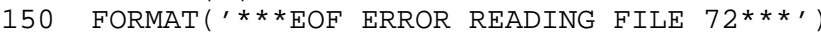

C 160 FORMAT ('RDBURN (F72) =', F10.3,' NCT=', I2) END

SUBROUTINE LAGINT (X, Y, N, XINT, YOUT)

C THIS SUBROUTINE PERFORMS LAGRANGIAN INTERPOLATION WITHIN A SET OF

C $(X, Y)$ PAIRS TO GIVE THE Y VALUE CORRESPONDING TO XINT. THE DEGREE OF

C THE INTERPOLATING POLYNOMIAL IS ONE LESS THAN THE NUMBER OF POINTS

C SUPPLIED. TAKEN FROM GERALD'S "APPLIED NUMERICAL ANALYSIS" PG 181

PARAMETERS ARE:

$X$ - ARRAY OF VALUES OF THE INDEPENDENT VARIABLE

$Y$ - ARRAY OF FUNCTION VALUES CORRESPONDING TO X

$\mathrm{N}$ - NUMBER OF POINTS

XINT - THE X-VALUE FOR WHICH ESTIMATE OF Y IS DESIRED

YOUT - THE Y-VALUE RETURNED TO CALLER 


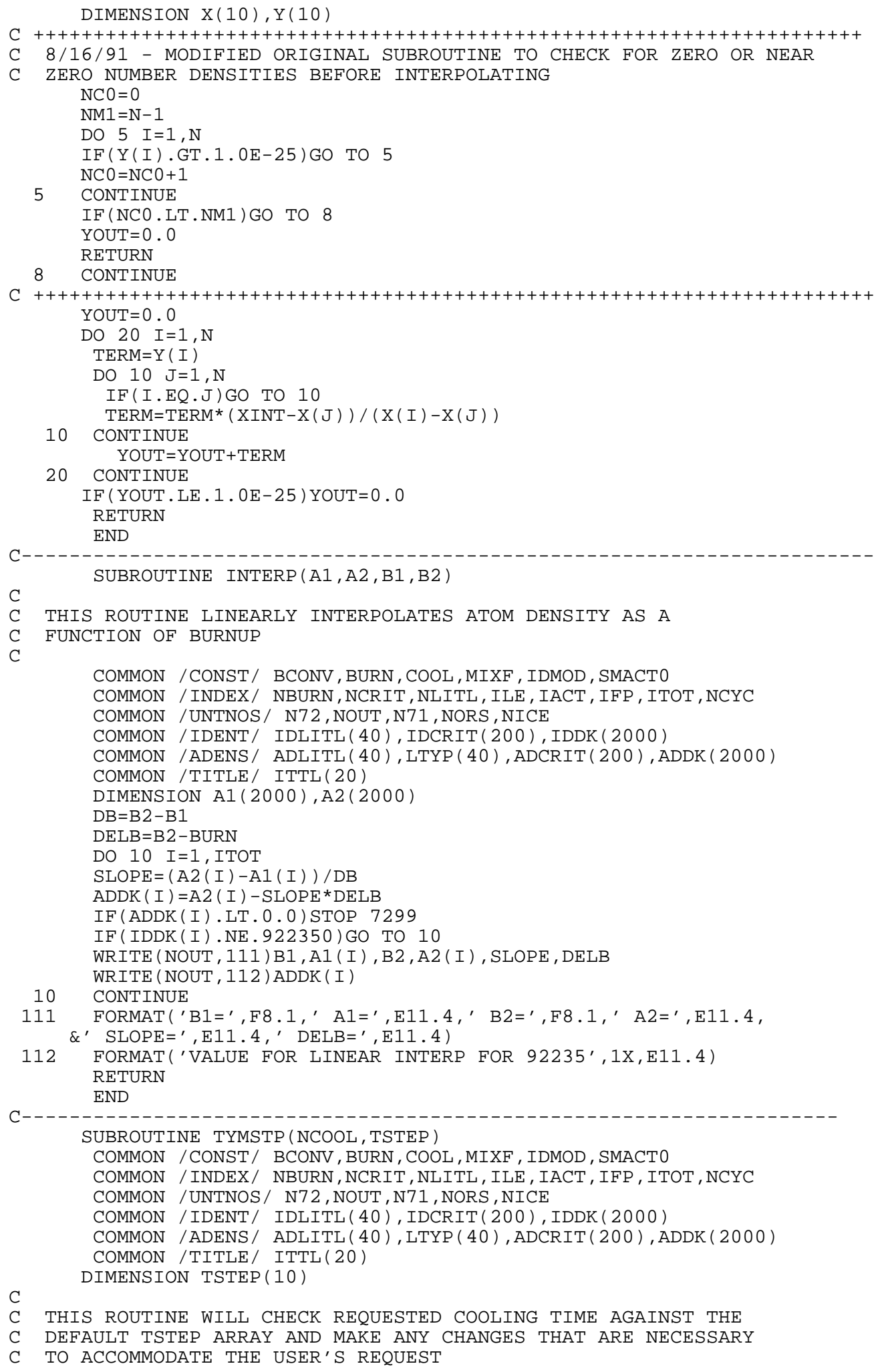




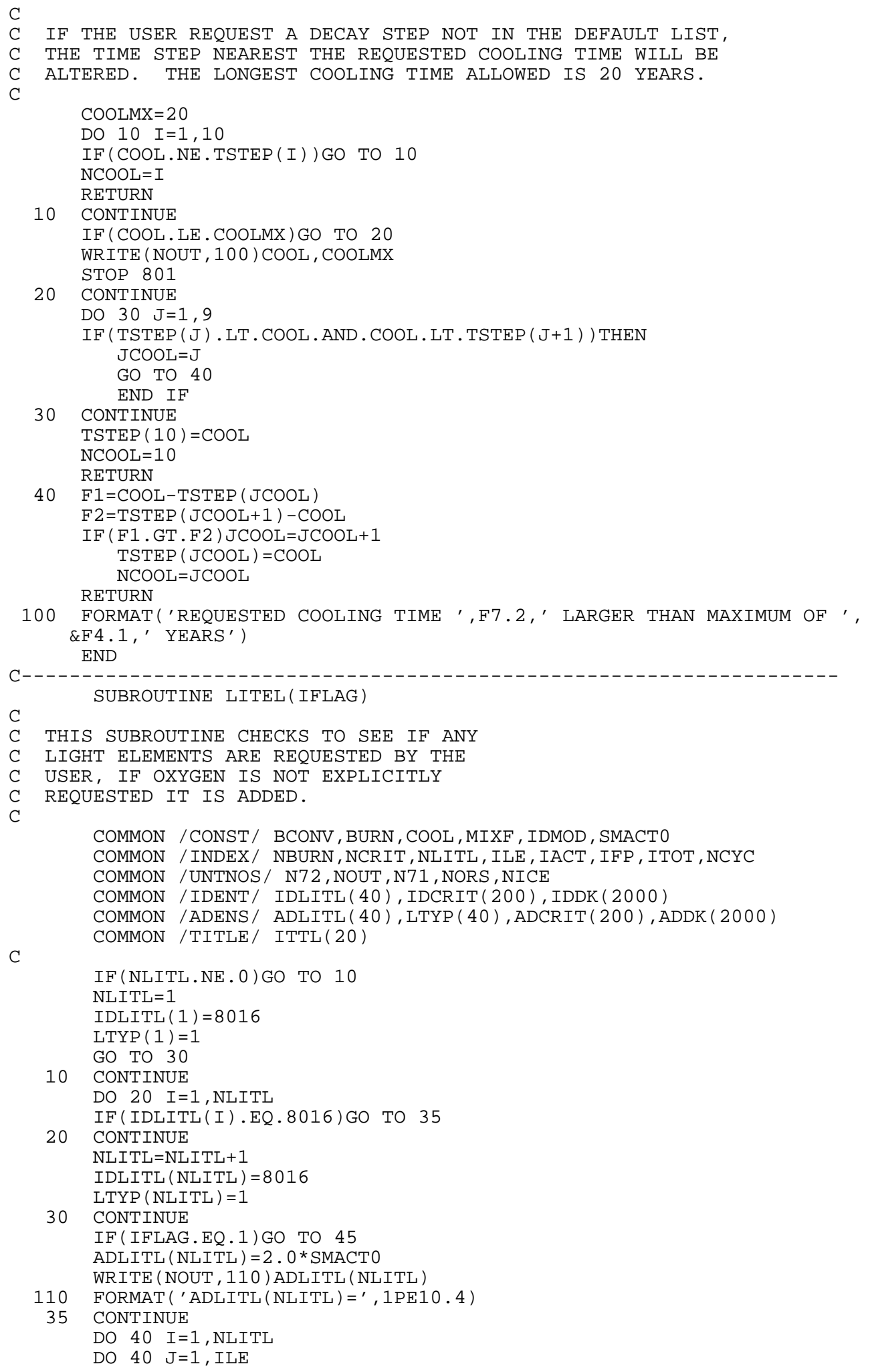




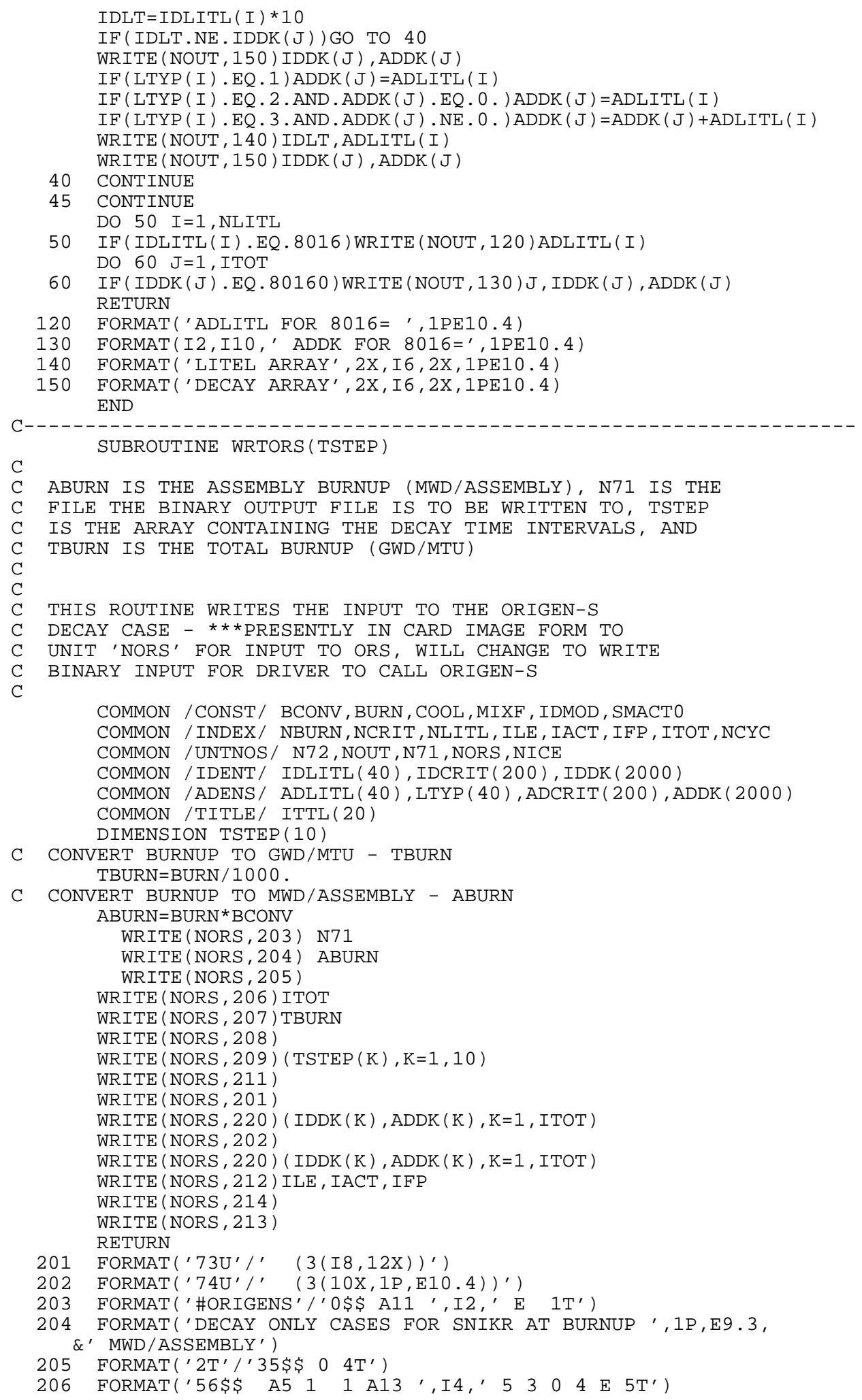




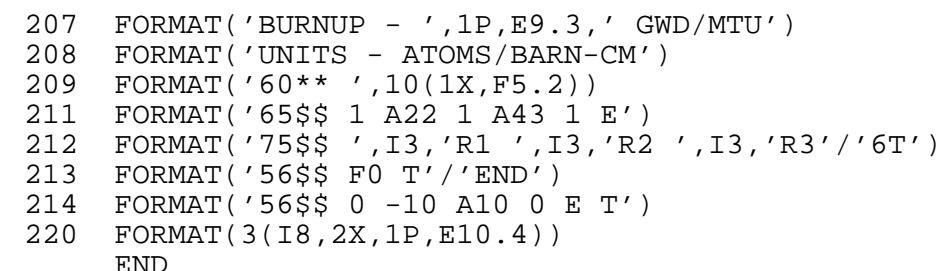

C READ NOUT, UNIT NUMBER FOR OUTPUT TO BE WRITTEN TO READ (N5, 140) NOUT

C READ NCOOL, NUMBER OF COOLING STEP FOR WHICH DENSITIES ARE TO BE READ IF (NCOOL.GT. 0) READ (N5, 110) 
IF (NCOOL.EQ.0) READ (N5, 145) NCOOL

$c$
$c$
$c$
$c$
$c$
$c$
$c$ KENO CALCULATIONS:

C $=0$ USE TTC713 INTERSECTION WITH SID BIERMAN'S NUCS

C 


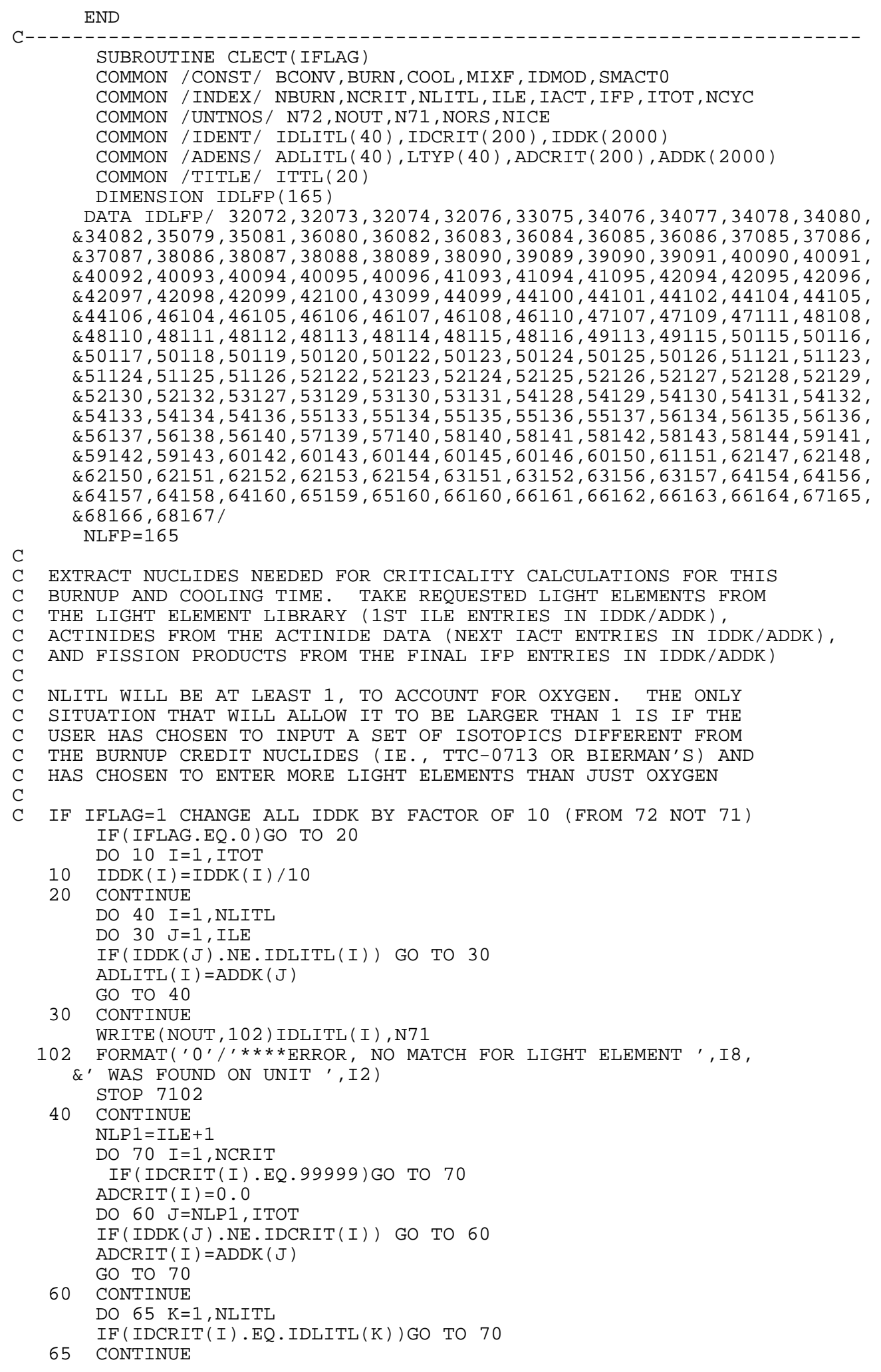




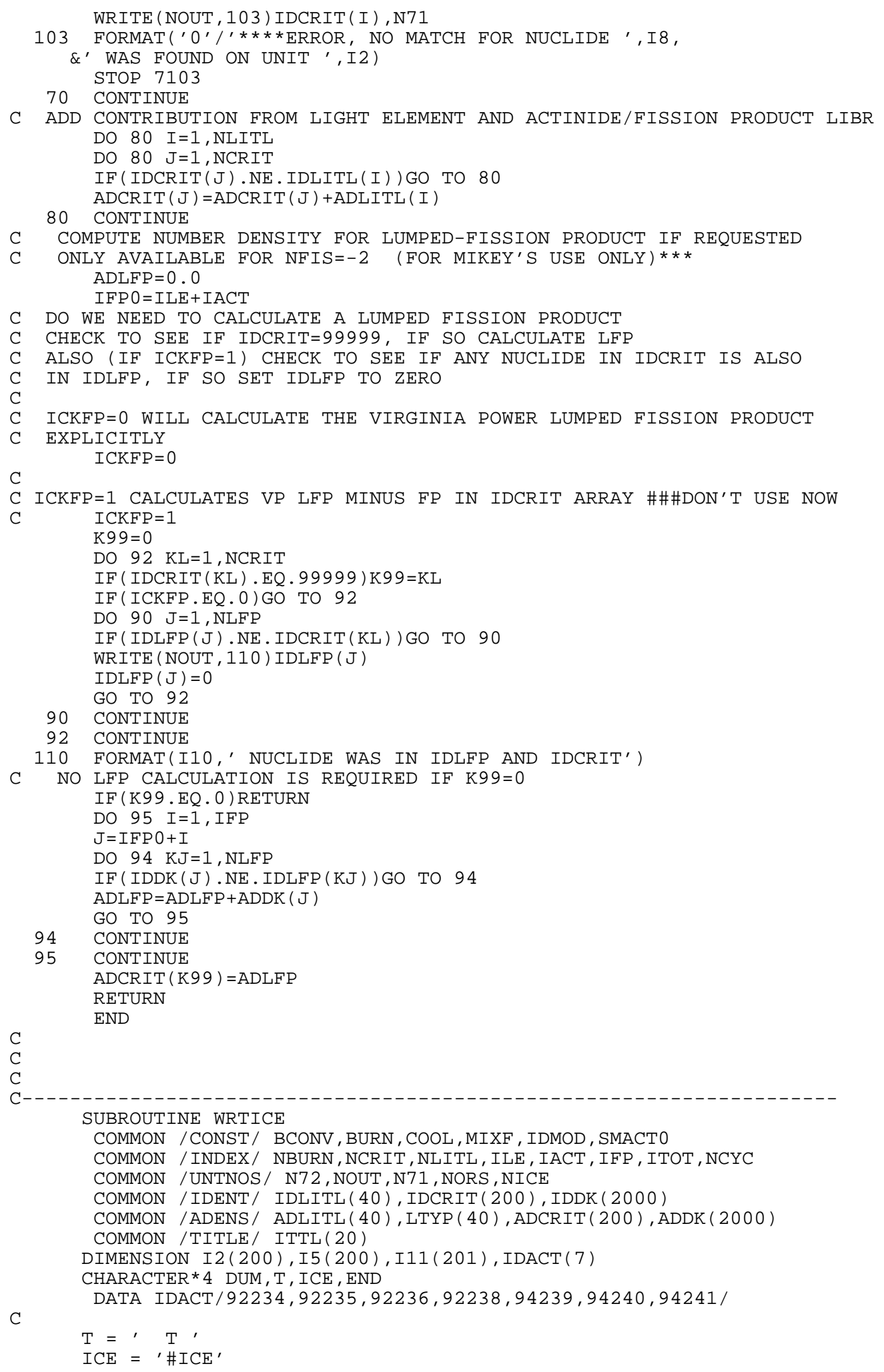




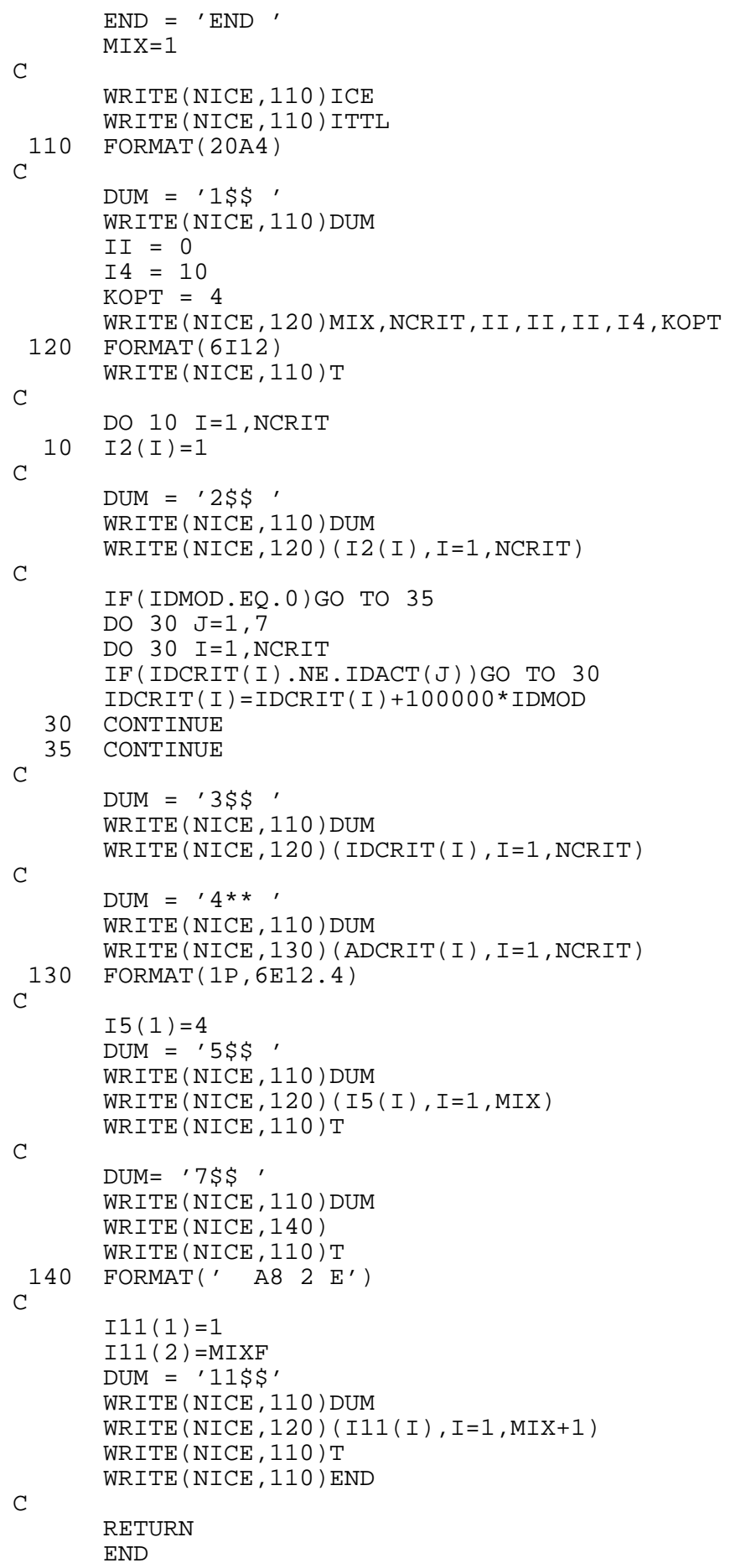




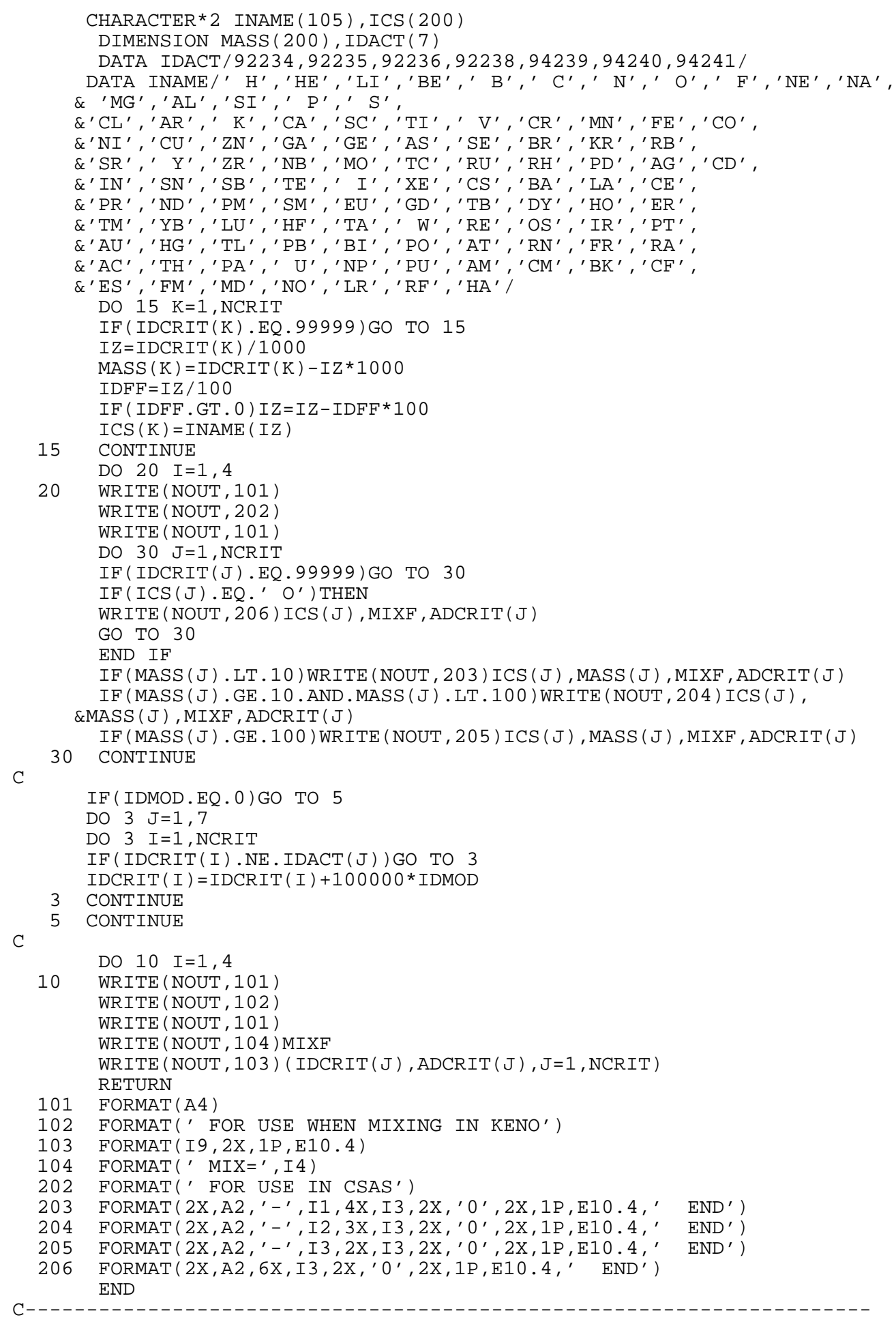




\section{SNIKR3 FORTRAN Listing}

C

PROGRAM SNIKR3

COMMON /CONST/ BCONV, BURN, COOL, MIXF, IDMOD, SMACTO

COMMON / INDEX/ NBURN, NCRIT, NLITL, ILE, IACT, IFP, ITOT, NCYC

COMMON /UNTNOS/ N72, NOUT, N71, NORS, NICE

COMMON /IDENT/ IDLITL(40), IDCRIT(210), IDDK (2000)

COMMON /ADENS/ ADLITL (40), LTYP (40), ADCRIT (200), ADDK (2000)

COMMON /TITLE/ ITTL(20)

DIMENSION TYM (20)

C READ SNIKRI INPUT AGAIN

CALL RDINPT1

C READ INPUT TO SNIKR NEEDED TO SET UP ICE RUN

$\mathrm{NCOOL}=0$

CALL RDINPT3 (NCOOL)

C RETRIEVE NUMBER DENSITIES AT COOLTIME FOR NUCLIDES TO BE USED IN

C CRITICALITY ANALYSES

$\mathrm{NNCT}=0$

NNCL $=1$

IF (NCOOL.LT.0) THEN

$\mathrm{NCOOL}=0$

NNCL $=11$

END IF

1000 CONTINUE

$\mathrm{NNCT}=\mathrm{NNCT}+1$

NPOS $=$ NCOOL + NNCT

CALL RDF71 (NPOS, TYM)

REWIND N71

CALL LITEL (1)

CALL CLECT $(0)$

C SET UP ICE RUN TO CREATE MIXTURE CROSS SECTIONS FOR KENO CALCS

C FIRST REMOVE ANY NUCLIDES WITH NUMBER DENSITIES LESS THAN 1E-24 WRITE (NOUT, 107) NPOS

WRITE (NOUT, 108) TYM (NPOS)

WRITE (NICE, 107) NPOS

WRITE (NICE, 108) TYM (NPOS)

CALL WRTICE

C USE MIXED CROSS SECTIONS WRITTEN ON UNIT NICE IN KENO CALC

C $\star * \star * * * * * * *$ CHECK FILE NOUT FOR MESSAGES

C WRITE NUMBER DENSITIES FOR MIXING IN KENO TO ...NOUT3

107 FORMAT (' ISOTOPIC RESULTS FOR COOL STEP ', I2)

108 FORMAT ('ORIGENS COOLING TIME (YR) $=^{\prime}, \mathrm{F} 6.2$ )

CALL WRTKENO

IF (NNCT.LT.NNCL) GO TO 1000

STOP

END

$\mathrm{C}$

C READ INPUT DATA FOR PHASE ONE CALCULATIONS, READING SAS2H OUTPUT

C AND SETTING UP ORIGEN-S DECAY ONLY CASE

C

SUBROUTINE RDINPT1

COMMON /CONST/ BCONV, BURN, COOL, MIXF, IDMOD, SMACTO

COMMON / INDEX/ NBURN, NCRIT, NLITL, ILE, IACT, IFP, ITOT, NCYC

COMMON /UNTNOS/ N72, NOUT, N71, NORS, NICE

COMMON /IDENT/ IDLITL(40), IDCRIT(210), IDDK (2000)

COMMON /ADENS/ ADLITL (40), LTYP (40), ADCRIT (200), ADDK (2000)

COMMON /TITLE/ ITTL(20)

CHARACTER * 6 ICHK

$\mathrm{N} 5=5$

READ (N5, 110) ICHK

C READ AND CHECK IF APPROPRIATE PHASE INPUT - SNIKR1

IF (ICHK.NE.' SNIKR1') STOP 5101

C READ TITLE CARD

READ (N5, 120) ITTL 
C READ LABEL AND CHECK TO BE SURE BURN DATA IS NEXT READ (N5, 110) ICHK

IF (ICHK.NE.'READ B') STOP 5102

C READ N72, UNIT NUMBER FOR SAS2H FILE 72 OUTPUT TO BE READ FROM READ (N5, 130) N72

C READ NOUT, UNIT NUMBER FOR OUTPUT TO BE WRITTEN TO READ (N5, 140) NOUT

C READ BURNUP IN MWD/MTU THAT NUMBER DENSITIES ARE TO BE RETRIEVED FROM N72 READ (N5, 150) BURN

C READ METAL (MTU/ASSEMBLY), BCONV IS CONVERSION FACTOR FOR BURNUPS

READ FROM N72 READ (N5, 160) BCONV

$\star * \star *$ MODIFIED SNIKR, NOW READ FROM SAS2H OUTPUT

READ NCYC, NUMBER OF BURN CYCLES USED TO PRODUCE SAS2H OUTPUT ON N72 READ (N5, 170) NCYC

C READ AND CHECK THAT THIS IS END OF BURNUP DATA READ (N5, 110) ICHK IF (ICHK.NE.'END BU') STOP 5103

C READ AND CHECK THAT DECAY DATA BEGINS WITH NEXT CARD READ (N5,110) ICHK IF (ICHK.NE.' READ D') STOP 5104

C READ NORS, UNIT NUMBER FOR ORIGEN-S INPUT TO BE WRITTEN READ (N5, 140) NORS

C READ N71, UNIT NUMBER FOR ORIGEN-S INPUT TO BE WRITTEN FOR PHASE 3 READ (N5, 130) N71

C READ COOLING TIME IN YEARS TO BE USED TO SET UP ORIGEN-S DECAY CASE READ (N5, 180) COOI

C READ THE NUMBER OF LIGHT ELEMENTS TO BE SPECIFIED IN THE DECAY CASE READ (N5, 190) NLITL

C READ AND CHECK THAT THIS IS THE END OF DECAY DATA $\operatorname{READ}(\mathrm{N} 5,110)$ ICHK IF (ICHK.NE.'END DE') STOP 5105

C IF NLITL IS GREATER THAN ZERO READ IN ID'S OF LIGHT ELEMENTS IF (NLITL.EQ.O) GO TO 1000 $\operatorname{READ}(\mathrm{N} 5,195)$ (IDLITL (I) , $\operatorname{ADLITL}(\mathrm{I}), \operatorname{LTYP}(\mathrm{I}), \mathrm{I}=1, \operatorname{NLITL})$

1000 CONTINUE

WRITE INPUT TO NOUT

WRITE (NOUT, 120) ITTL

WRITE (NOUT, 130) N72

WRITE (NOUT, 140$)$ NOUT

WRITE (NOUT, 150) BURN

WRITE (NOUT, 160) BCONV

WRITE (NOUT, 170) NCYC

WRITE (NOUT, 140) NORS

WRITE (NOUT, 180) COOL

WRITE (NOUT, 190) NLITI RETURN

110 FORMAT (A6)

120 FORMAT (20A4)

130 FORMAT $(4 \mathrm{X}, \mathrm{I} 2)$

140 FORMAT (5X, I 2)

150 FORMAT (5X, F 8.1)

160 FORMAT $(6 \mathrm{X}, \mathrm{F} 6.4)$

170 FORMAT ( $5 \mathrm{X}, \mathrm{I} 2)$

180 FORMAT ( $8 X, F 6.2)$

190 FORMAT (8X, I2)

195 FORMAT (1X, I5 , 1P , E10.4 , OP , 2X, I1) END

C

C

SUBROUTINE RDINPT3 (NCOOL)

COMMON /CONST/ BCONV, BURN, COOL, MIXF, IDMOD, SMACTO

COMMON / INDEX/ NBURN, NCRIT, NLITL, ILE, IACT, IFP, ITOT, NCYC

COMMON /UNTNOS/ N72, NOUT, N71, NORS, NICE 


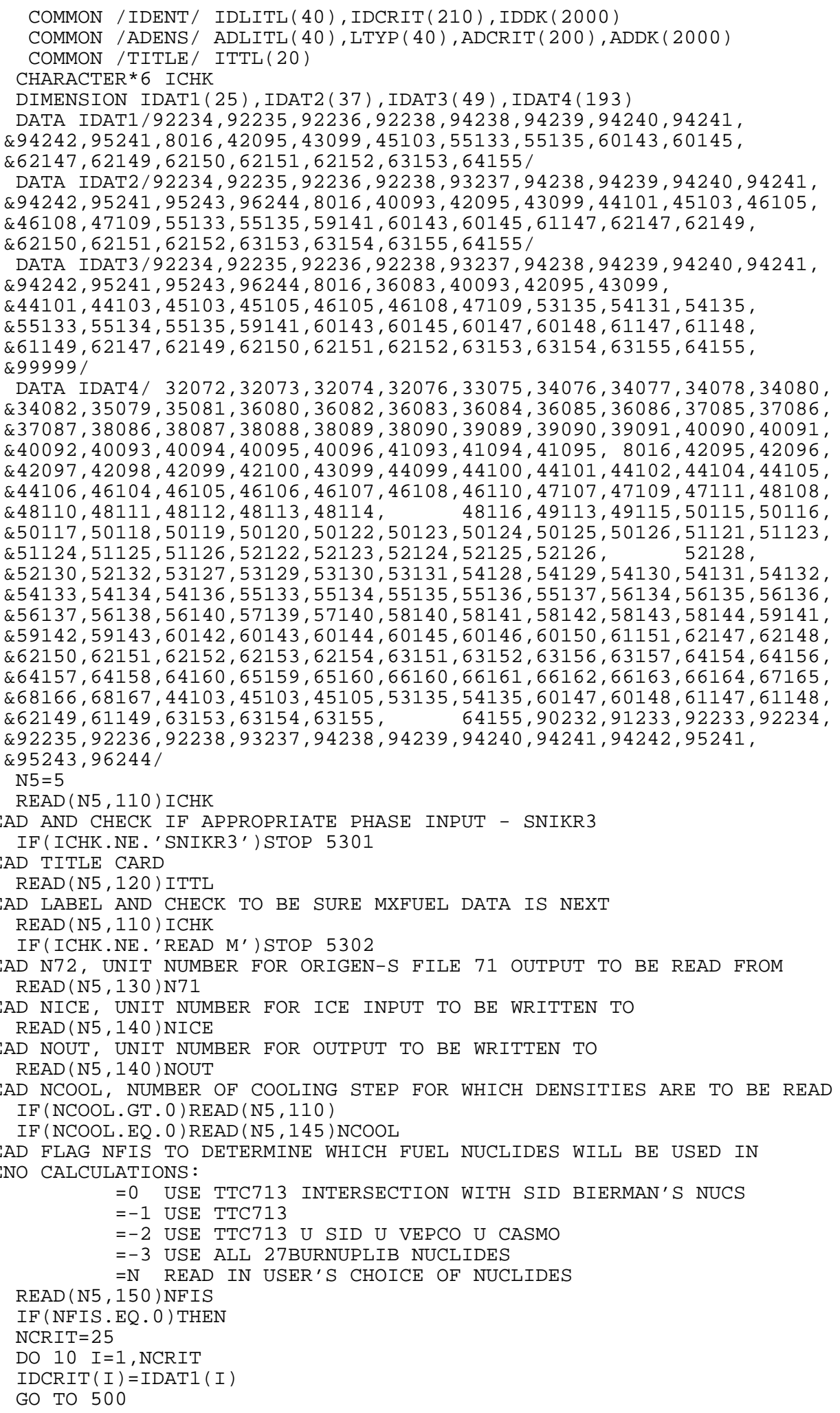




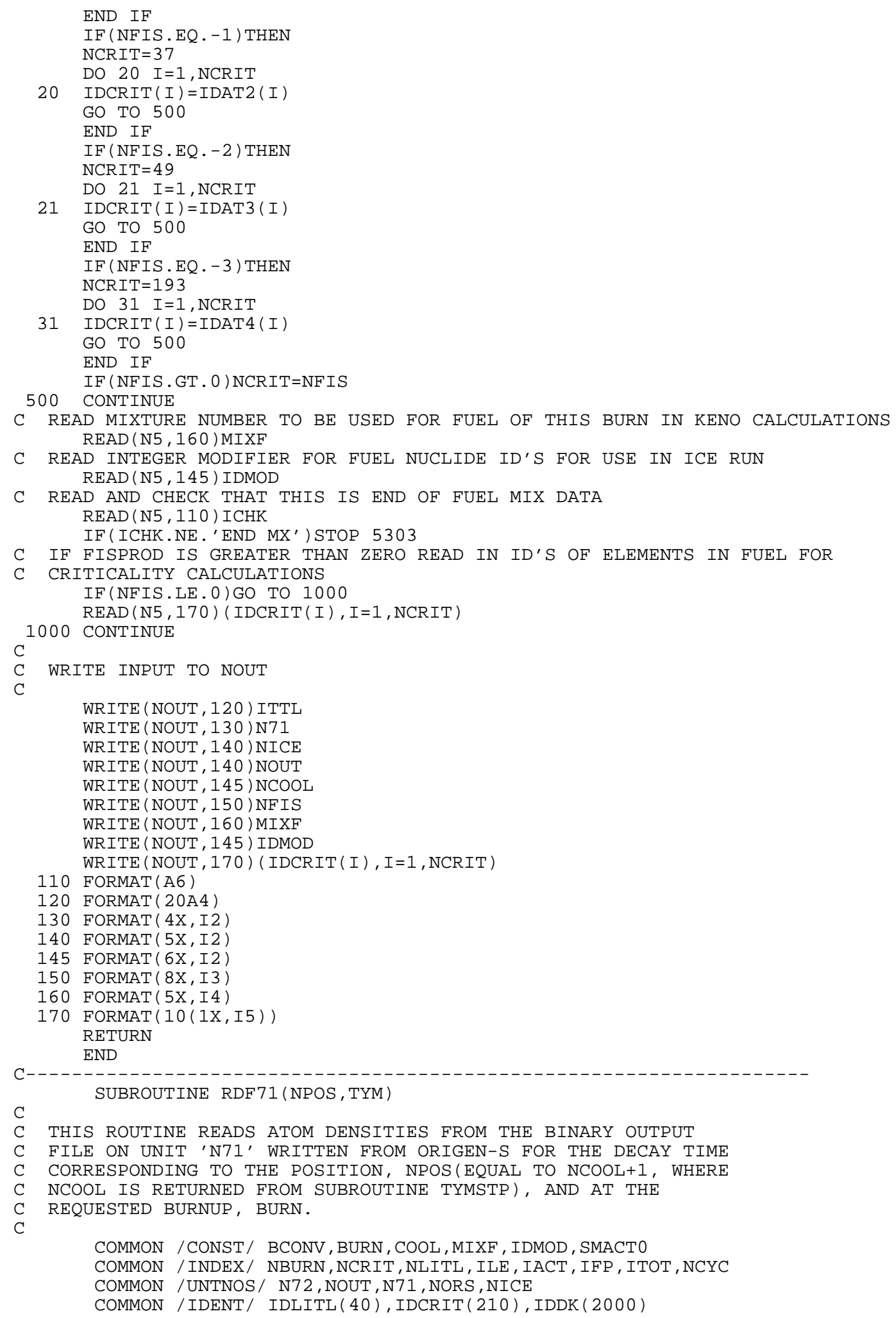

COMMON /CONST/ BCONV, BURN, COOL, MIXF, IDMOD, SMACTO COMMON / INDEX/ NBURN, NCRIT, NLITL, ILE, IACT, IFP, ITOT, NCYC COMMON /UNTNOS/ N72, NOUT, N71, NORS, NICE

COMMON /IDENT/ IDLITL(40), IDCRIT(210), IDDK(2000) 


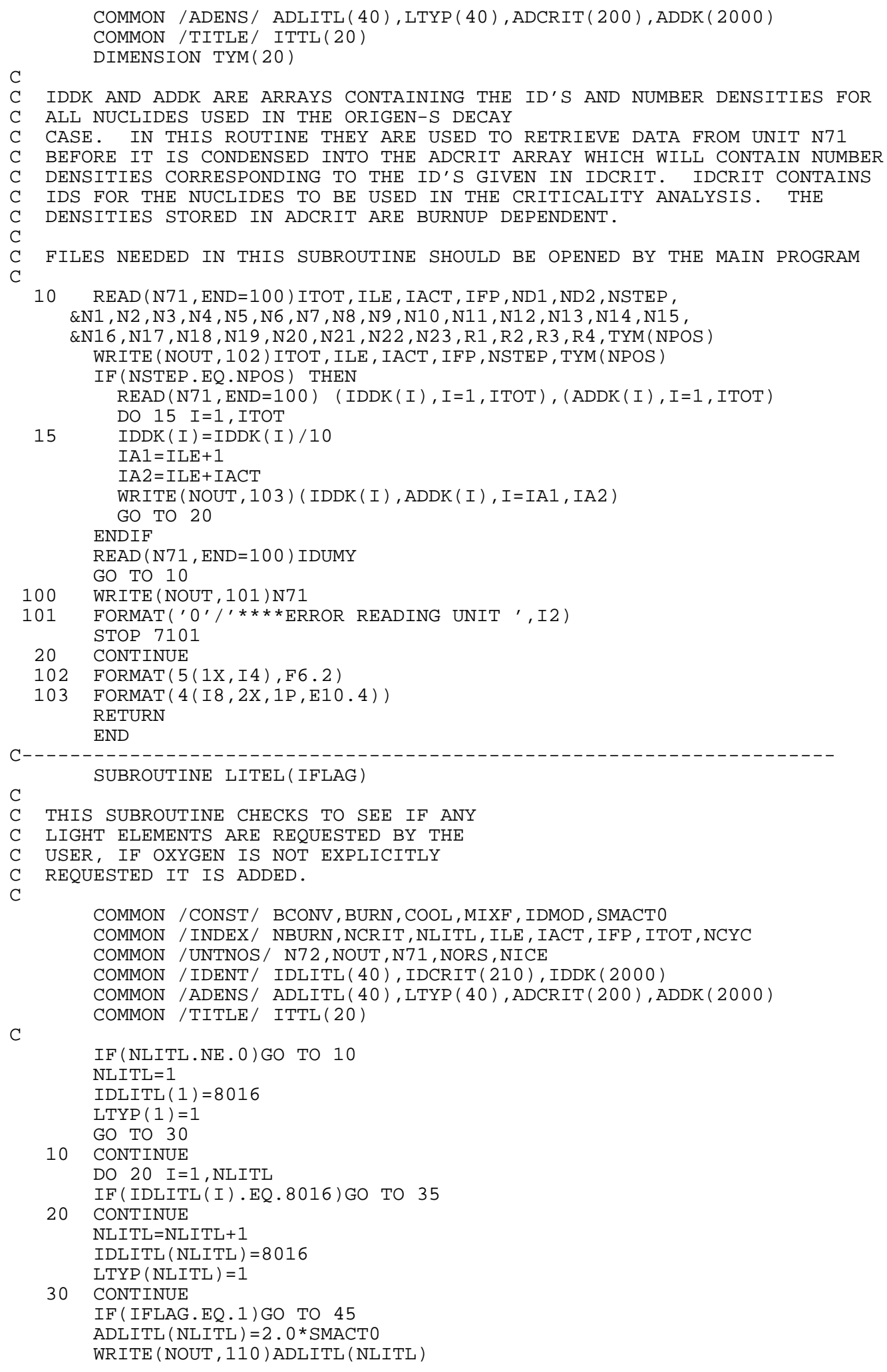




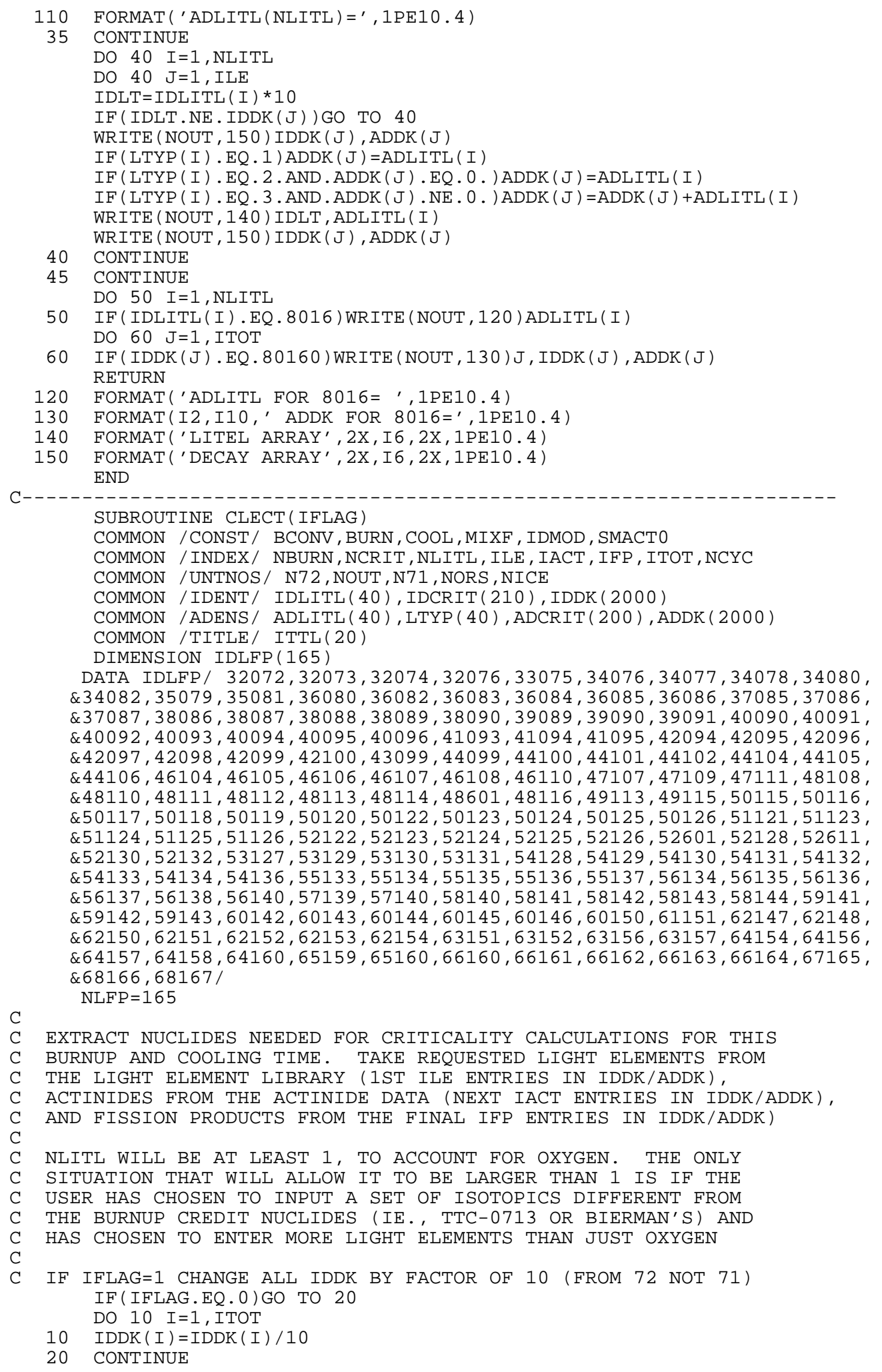




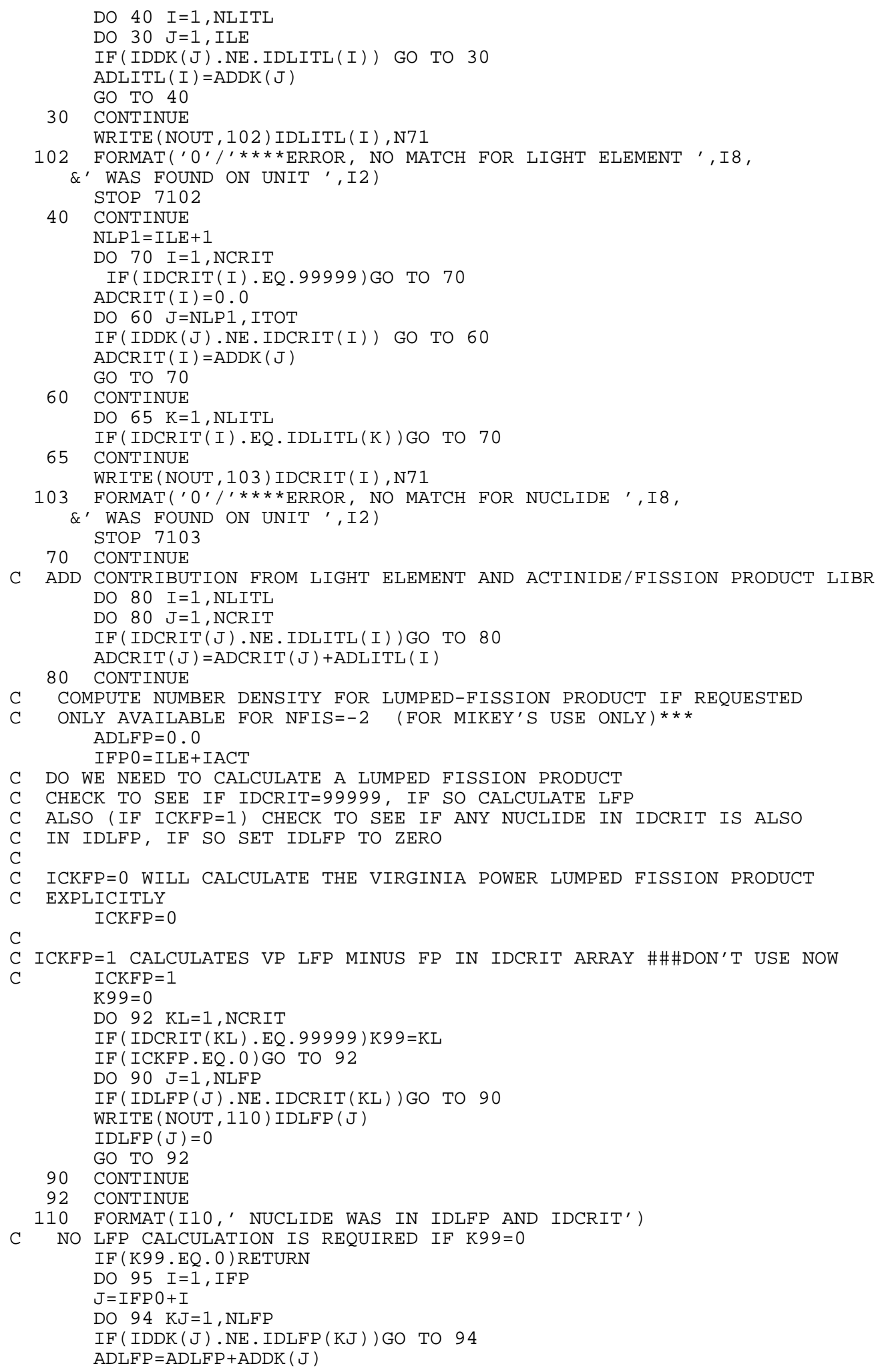




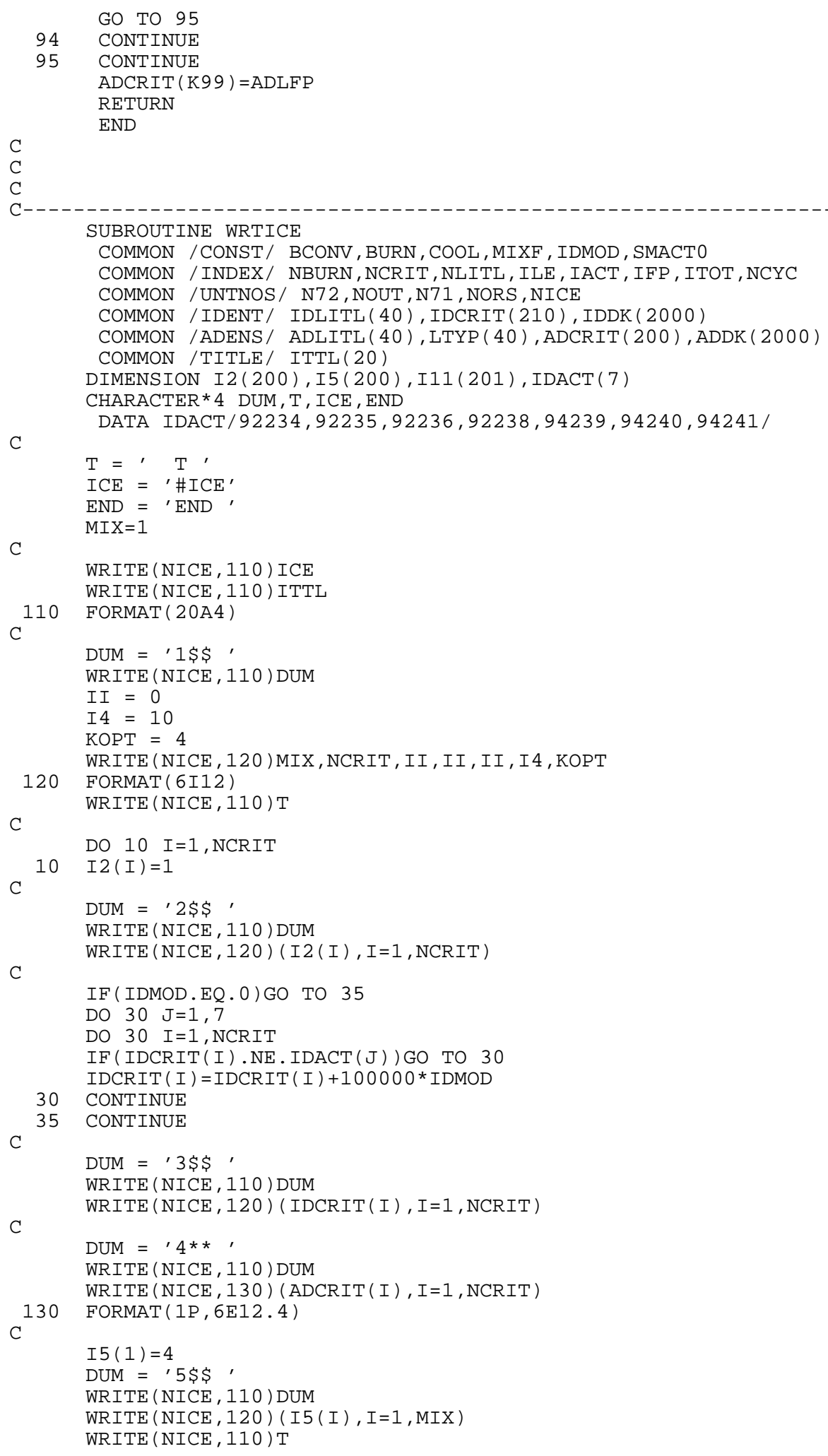


C

$\mathrm{DUM}=, 7 \$ \$$,

WRITE (NICE, 110) DUM

WRITE (NICE, 140)

WRITE (NICE, 110) T

140 FORMAT (' A8 2 E')

$\mathrm{C}$

$\operatorname{I11}(1)=1$

$\operatorname{III}(2)=\operatorname{MIXF}$

$\mathrm{DUM}=\prime 11 \$ \$ \prime$

WRITE (NICE, 110) DUM

WRITE (NICE, 120) (I11 (I), I=1, MIX+1)

WRITE (NICE, 110) T

C

WRITE (NICE, 110) END

RETURN

END

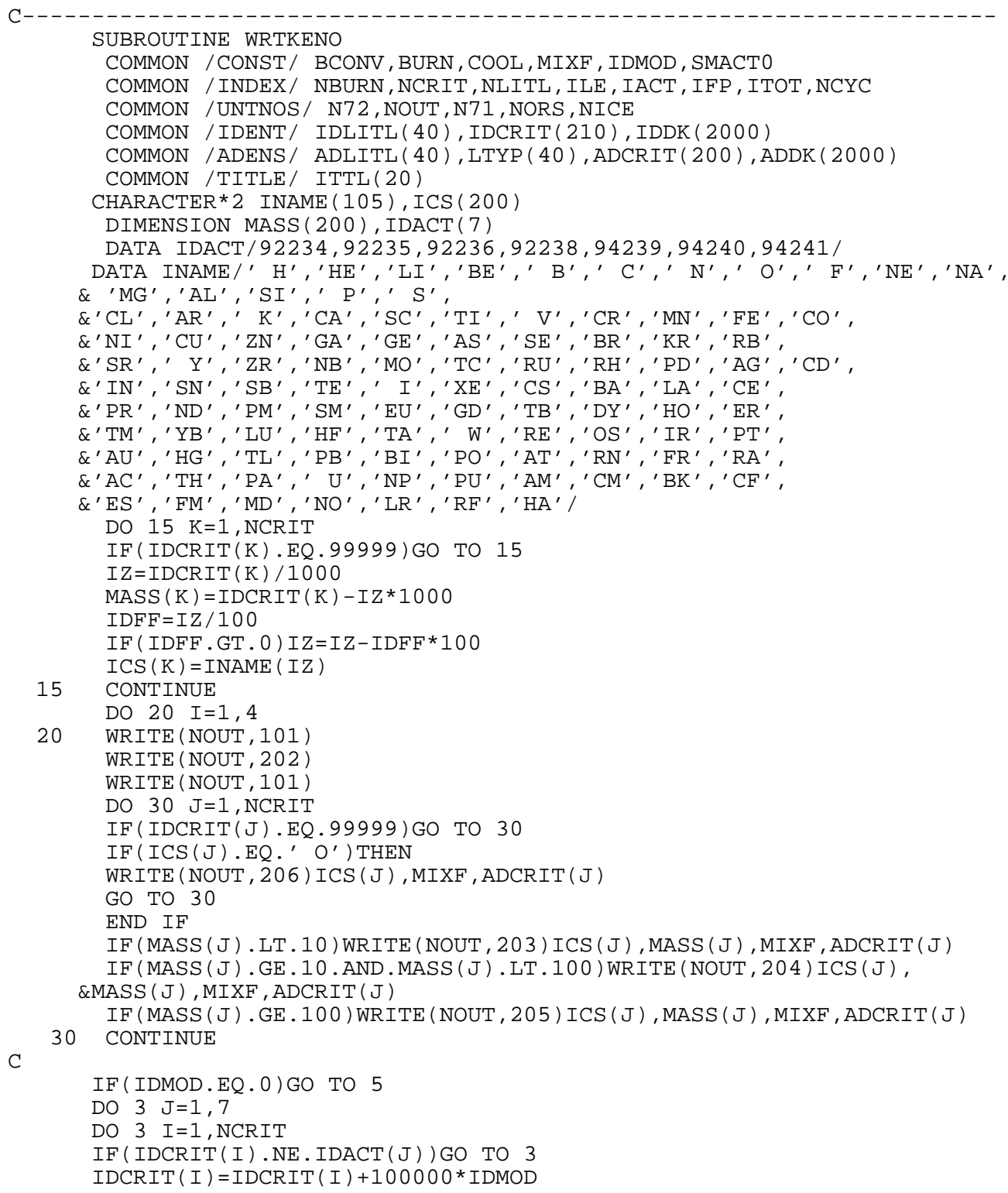




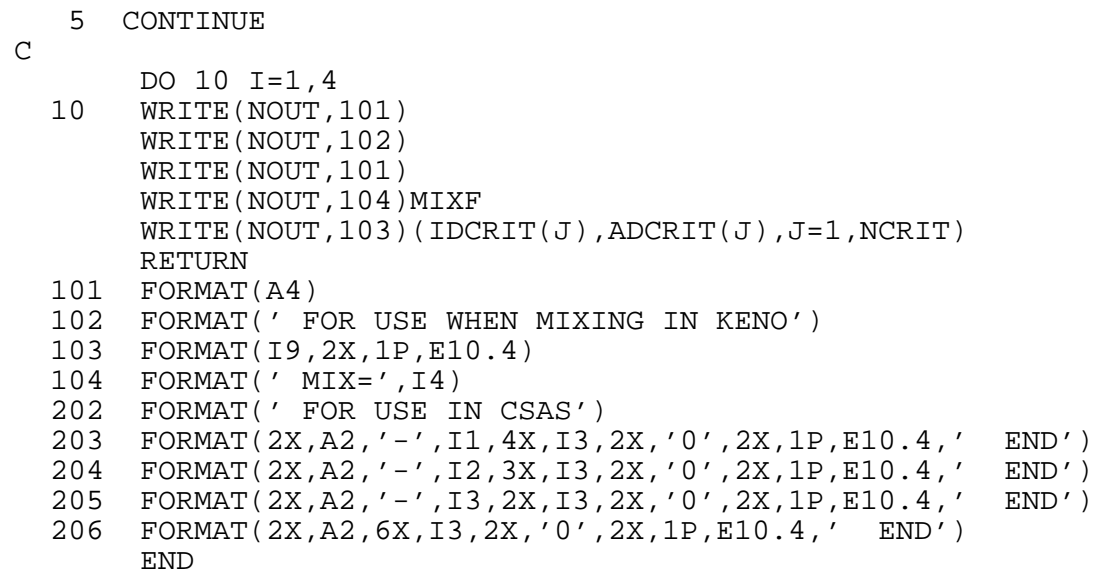




\section{Sample SNIKR Output}

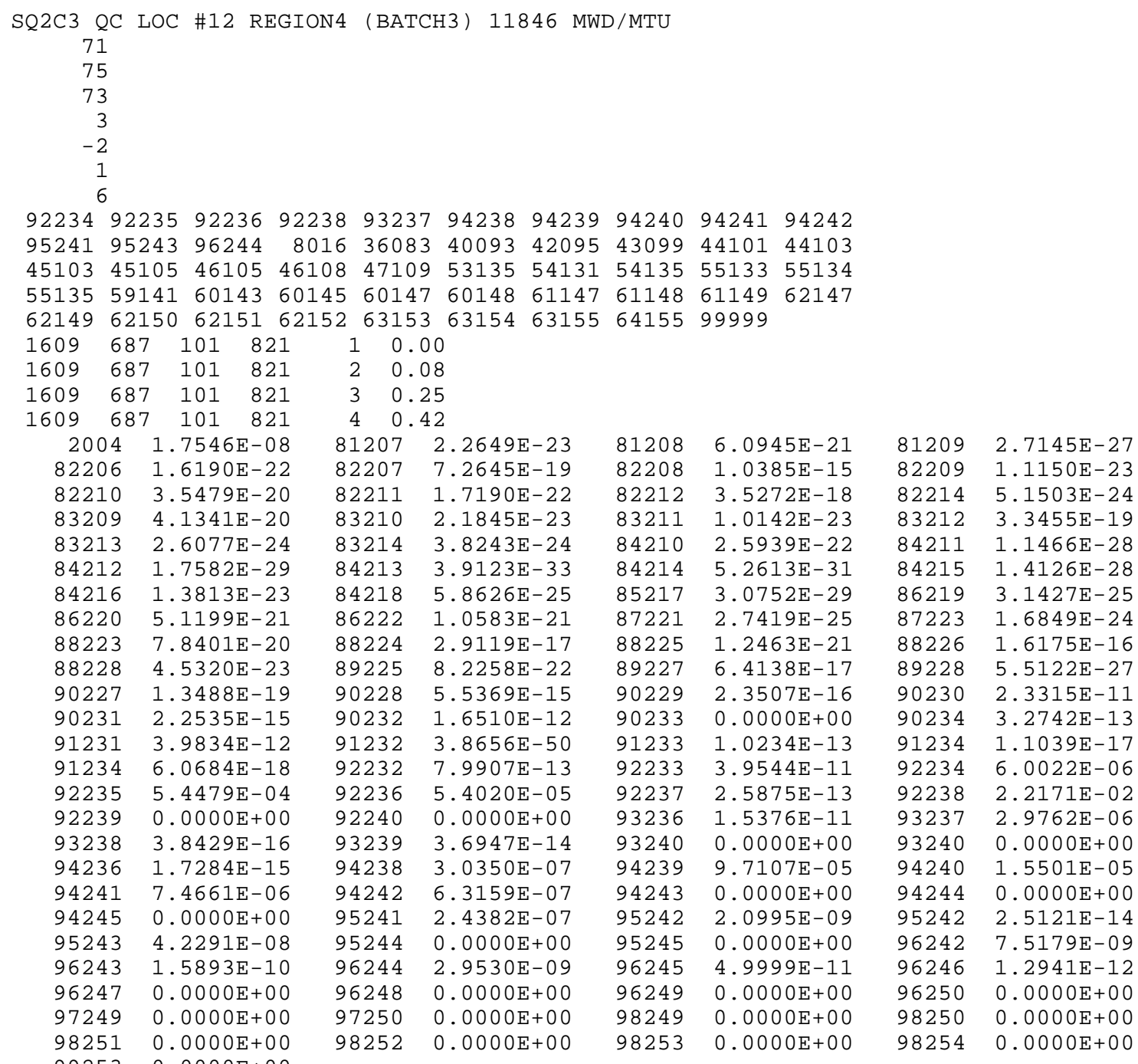

ADLITL FOR $8016=0.0000 \mathrm{E}+00$

ISOTOPIC RESULTS FOR COOL STEP 4

ORIGENS COOLING TIME $(\mathrm{YR})=0.42$

FOR USE IN CSAS

$\begin{array}{rllll}\mathrm{U}-234 & 1 & 0 & 6.0022 \mathrm{E}-06 & \text { END } \\ \mathrm{U}-235 & 1 & 0 & 5.4479 \mathrm{E}-04 & \text { END } \\ \mathrm{U}-236 & 1 & 0 & 5.4020 \mathrm{E}-05 & \text { END } \\ \mathrm{U}-238 & 1 & 0 & 2.2171 \mathrm{E}-02 & \text { END } \\ \mathrm{NP}-237 & 1 & 0 & 2.9762 \mathrm{E}-06 & \text { END } \\ \mathrm{PU}-238 & 1 & 0 & 3.0350 \mathrm{E}-07 & \mathrm{END} \\ \mathrm{PU}-239 & 1 & 0 & 9.7107 \mathrm{E}-05 & \text { END } \\ \mathrm{PU}-240 & 1 & 0 & 1.5501 \mathrm{E}-05 & \text { END } \\ \mathrm{PU}-241 & 1 & 0 & 7.4661 \mathrm{E}-06 & \mathrm{END} \\ \mathrm{PU}-242 & 1 & 0 & 6.3159 \mathrm{E}-07 & \text { END }\end{array}$




$\begin{array}{ccccc}\text { AM-241 } & 1 & 0 & 2.4382 E-07 & \text { END } \\ \text { AM-243 } & 1 & 0 & 4.2291 E-08 & \text { END } \\ \text { CM-244 } & 1 & 0 & 2.9530 E-09 & \text { END } \\ \text { O } & 1 & 0 & 4.6385 E-02 & \text { END } \\ \text { KR-83 } & 1 & 0 & 1.3232 E-06 & \text { END } \\ \text { ZR-93 } & 1 & 0 & 1.7074 E-05 & \text { END } \\ \text { MO-95 } & 1 & 0 & 1.5972 E-05 & \text { END } \\ \text { TC-99 } & 1 & 0 & 1.7261 E-05 & \text { END } \\ \text { RU-101 } & 1 & 0 & 1.5200 E-05 & \text { END } \\ \text { RU-103 } & 1 & 0 & 1.4686 E-07 & \text { END } \\ \text { RH-103 } & 1 & 0 & 9.9860 E-06 & \text { END } \\ \text { RH-105 } & 1 & 0 & 2.6076 E-39 & \text { END } \\ \text { PD-105 } & 1 & 0 & 5.1564 E-06 & \text { END } \\ \text { PD-108 } & 1 & 0 & 1.3155 E-06 & \text { END } \\ \text { AG-109 } & 1 & 0 & 9.3884 E-07 & \text { END } \\ \text { I-135 } & 1 & 0 & 0.0000 E+00 & \text { END } \\ \text { XE-131 } & 1 & 0 & 8.0469 E-06 & \text { END } \\ \text { XE-135 } & 1 & 0 & 0.0000 E+00 & \text { END } \\ \text { CS-133 } & 1 & 0 & 1.8970 E-05 & \text { END } \\ \text { CS-134 } & 1 & 0 & 6.2227 E-07 & \text { END } \\ \text { CS-135 } & 1 & 0 & 5.4754 E-06 & \text { END } \\ \text { PR-141 } & 1 & 0 & 1.6396 E-05 & \text { END } \\ \text { ND-143 } & 1 & 0 & 1.5116 E-05 & \text { END } \\ \text { ND-145 } & 1 & 0 & 1.0599 E-05 & \text { END } \\ \text { ND-147 } & 1 & 0 & 2.4061 E-11 & \text { END } \\ \text { ND-148 } & 1 & 0 & 4.9465 E-06 & \text { END } \\ \text { PM-147 } & 1 & 0 & 4.1512 E-06 & \text { END } \\ \text { PM-148 } & 1 & 0 & 1.8042 E-11 & \text { END } \\ \text { PM-149 } & 1 & 0 & 6.8058 E-29 & \text { END } \\ \text { SM-147 } & 1 & 0 & 1.1179 E-06 & \text { END } \\ \text { SM-149 } & 1 & 0 & 1.4939 E-07 & \text { END } \\ \text { SM-150 } & 1 & 0 & 3.8662 E-06 & \text { END } \\ \text { SM-151 } & 1 & 0 & 4.1625 E-07 & \text { END } \\ \text { SM-152 } & 1 & 0 & 1.7197 E-06 & \text { END } \\ \text { EU-153 } & 1 & 0 & 9.3994 E-07 & \text { END } \\ \text { EU-154 } & 1 & 0 & 1.5726 E-07 & \text { END } \\ \text { EU-155 } & 1 & 0 & 9.7692 E-08 & \text { END } \\ \text { GD-155 } & 1 & 0 & 6.6207 E-09 & \text { END } \\ & & & & \end{array}$

FOR USE WHEN MIXING IN KENO

$\begin{array}{rr}\text { MIX }= & 1 \\ 692234 & 6.0022 \mathrm{E}-06 \\ 692235 & 5.4479 \mathrm{E}-04 \\ 692236 & 5.4020 \mathrm{E}-05 \\ 692238 & 2.2171 \mathrm{E}-02 \\ 93237 & 2.9762 \mathrm{E}-06 \\ 94238 & 3.0350 \mathrm{E}-07 \\ 694239 & 9.7107 \mathrm{E}-05 \\ 694240 & 1.5501 \mathrm{E}-05 \\ 694241 & 7.4661 \mathrm{E}-06 \\ 94242 & 6.3159 \mathrm{E}-07 \\ 95241 & 2.4382 \mathrm{E}-07 \\ 95243 & 4.2291 \mathrm{E}-08 \\ 96244 & 2.9530 \mathrm{E}-09 \\ 8016 & 4.6385 \mathrm{E}-02 \\ 36083 & 1.3232 \mathrm{E}-06 \\ 40093 & 1.7074 \mathrm{E}-05 \\ 42095 & 1.5972 \mathrm{E}-05 \\ 43099 & 1.7261 \mathrm{E}-05 \\ 44101 & 1.5200 \mathrm{E}-05\end{array}$


$\begin{array}{ll}44103 & 1.4686 \mathrm{E}-07 \\ 45103 & 9.9860 \mathrm{E}-06 \\ 45105 & 2.6076 \mathrm{E}-39 \\ 46105 & 5.1564 \mathrm{E}-06 \\ 46108 & 1.3155 \mathrm{E}-06 \\ 47109 & 9.3884 \mathrm{E}-07 \\ 53135 & 0.0000 \mathrm{E}+00 \\ 54131 & 8.0469 \mathrm{E}-06 \\ 54135 & 0.0000 \mathrm{E}+00 \\ 55133 & 1.8970 \mathrm{E}-05 \\ 55134 & 6.2227 \mathrm{E}-07 \\ 55135 & 5.4754 \mathrm{E}-06 \\ 59141 & 1.6396 \mathrm{E}-05 \\ 60143 & 1.5116 \mathrm{E}-05 \\ 60145 & 1.0599 \mathrm{E}-05 \\ 60147 & 2.4061 \mathrm{E}-11 \\ 60148 & 4.9465 \mathrm{E}-06 \\ 61147 & 4.1512 \mathrm{E}-06 \\ 61148 & 1.8042 \mathrm{E}-11 \\ 61149 & 6.8058 \mathrm{E}-29 \\ 62147 & 1.1179 \mathrm{E}-06 \\ 62149 & 1.4939 \mathrm{E}-07 \\ 62150 & 3.8662 \mathrm{E}-06 \\ 62151 & 4.1625 \mathrm{E}-07 \\ 62152 & 1.7197 \mathrm{E}-06 \\ 63153 & 9.3994 \mathrm{E}-07 \\ 63154 & 1.5726 \mathrm{E}-07 \\ 63155 & 9.7692 \mathrm{E}-08 \\ 64155 & 6.6207 \mathrm{E}-09 \\ 99999 & 5.6395 \mathrm{E}-04\end{array}$ 



\section{APPENDIX D}

\section{KENO-V.a BOC MODEL SETUP INPUT EXAMPLES}

This appendix gives examples of the input for the different calculational steps for setting up the Sequoyah Unit 2 Cycle 3 KENO-V.a models for BOC (HZP and HFP). 
Table D.1. SNIKR/ORIGEN-S input for fresh fuel batch/assembly isotopics

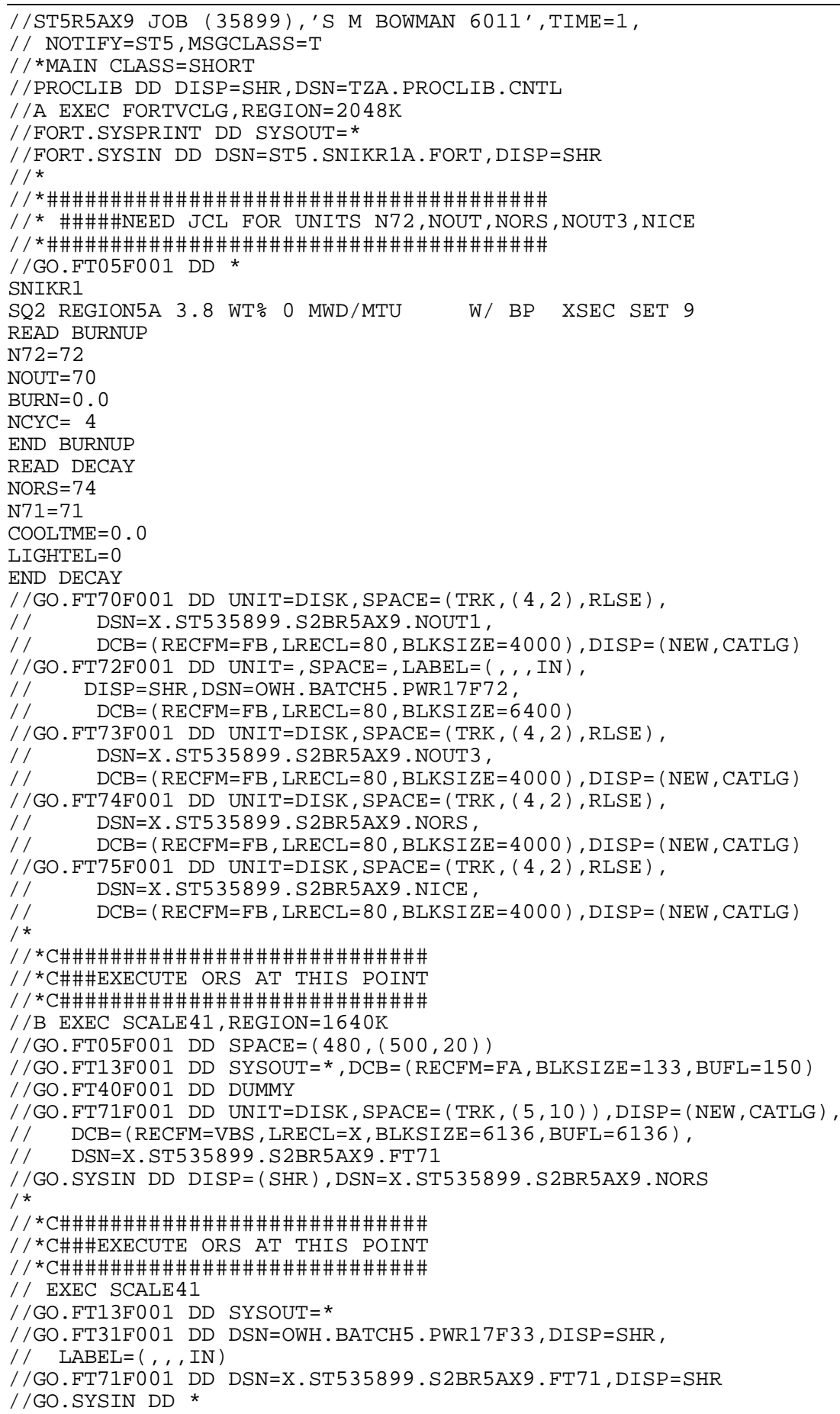


101

Table D.1. (continued)

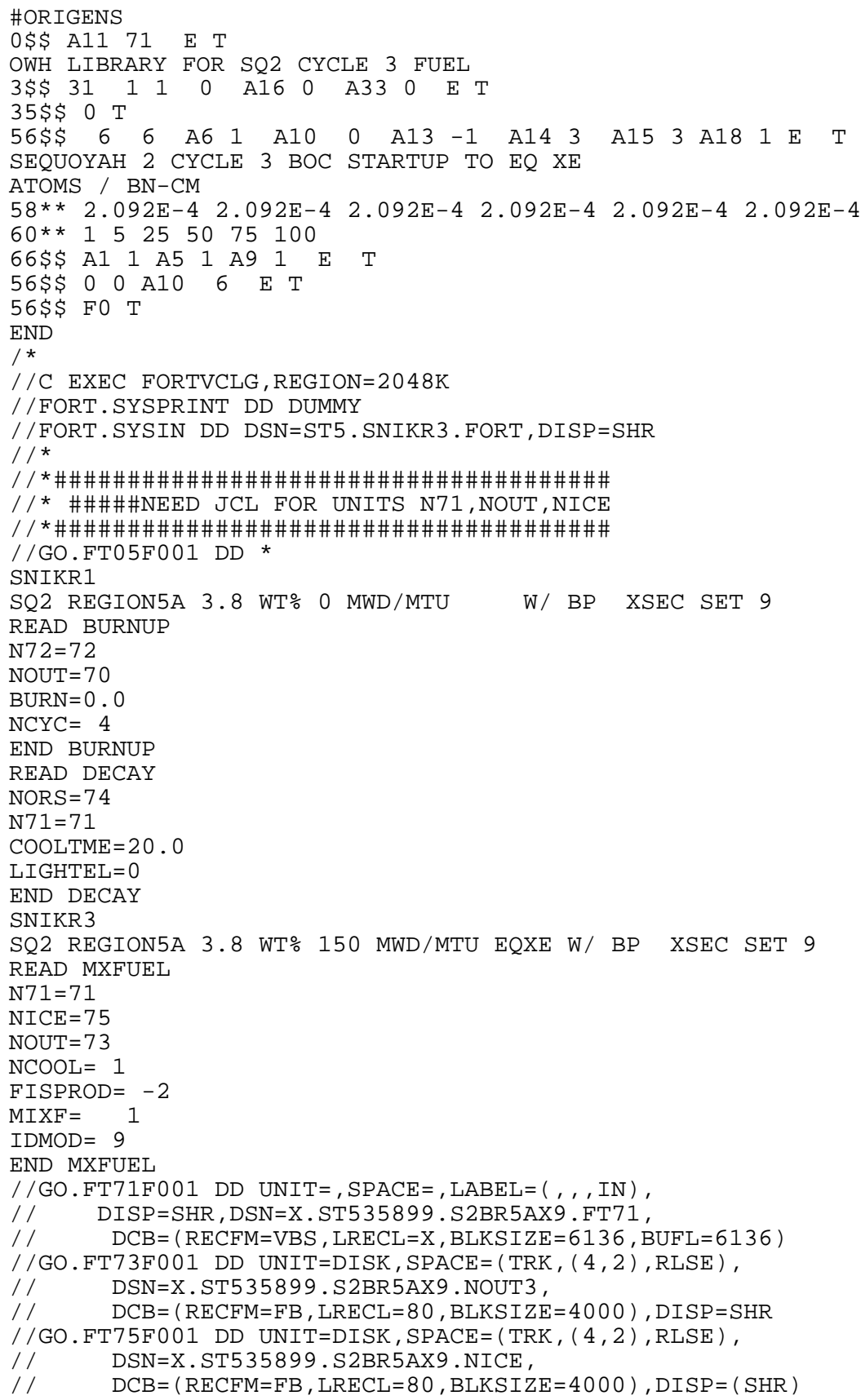




\section{Table D.2. SNIKR/ORIGEN-S input for BP isotopics}

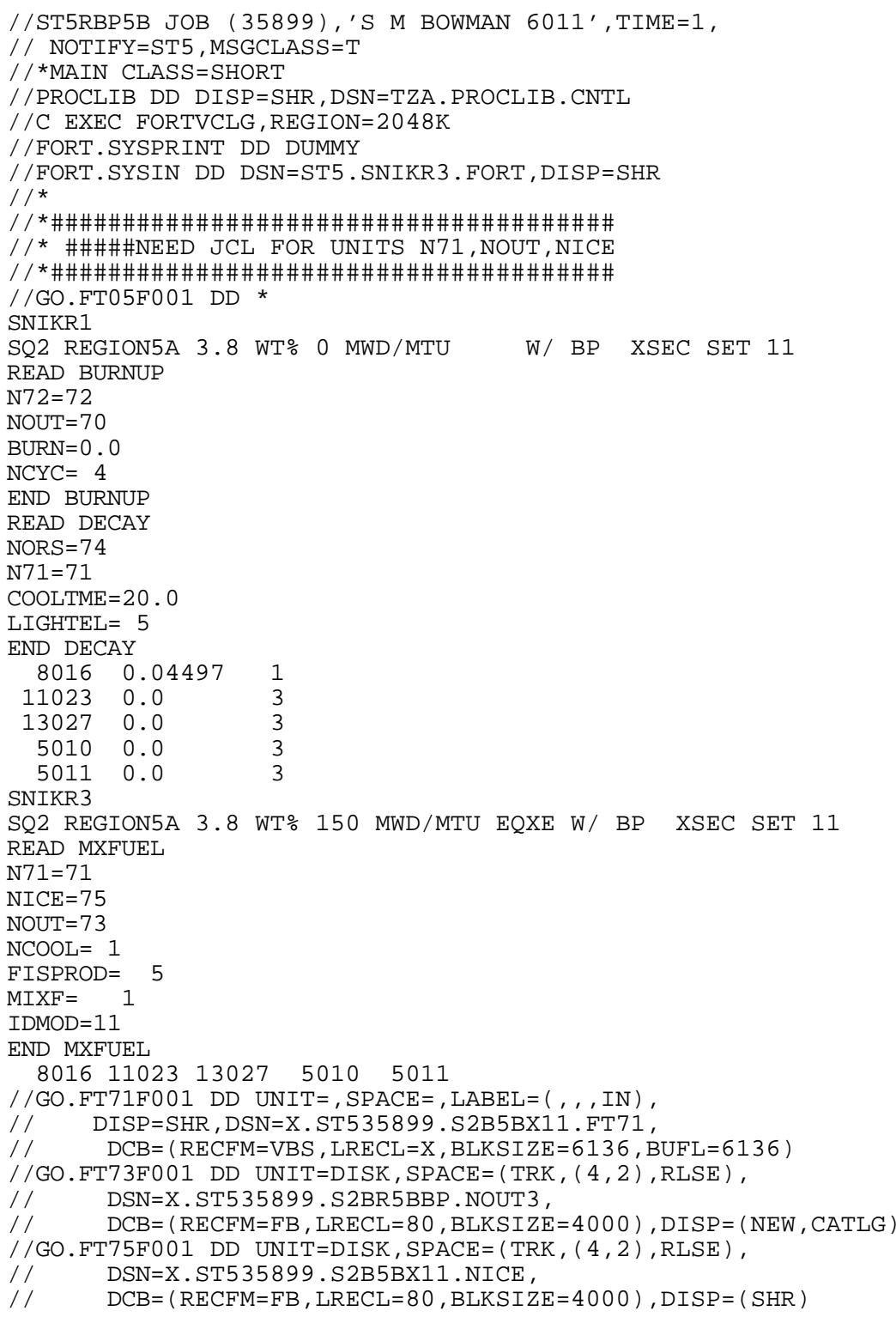




\section{Table D.3. SNIKR/ORIGEN-S input for cross-section set 4 average isotopics}

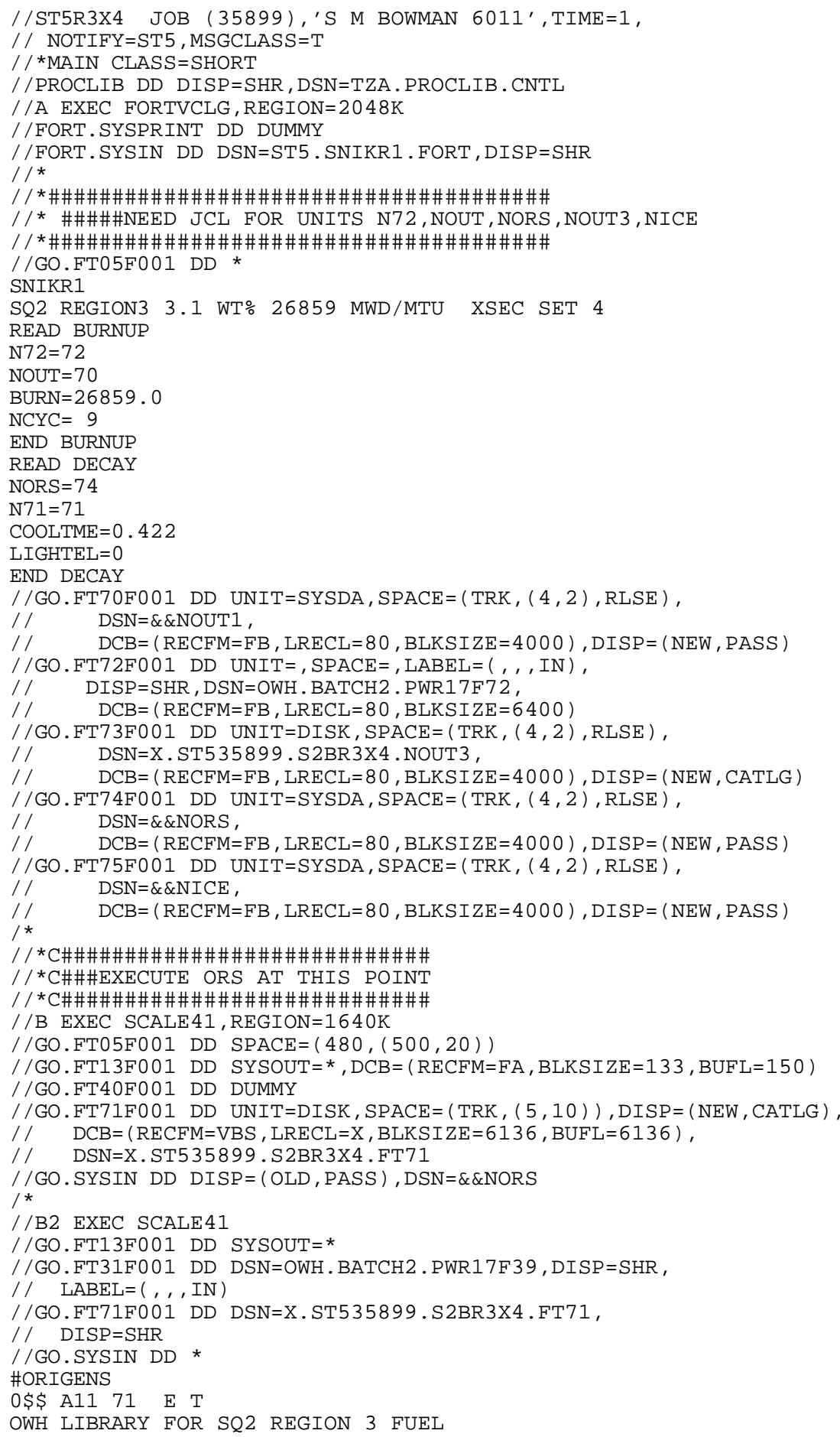


104

Table D.3. (continued)

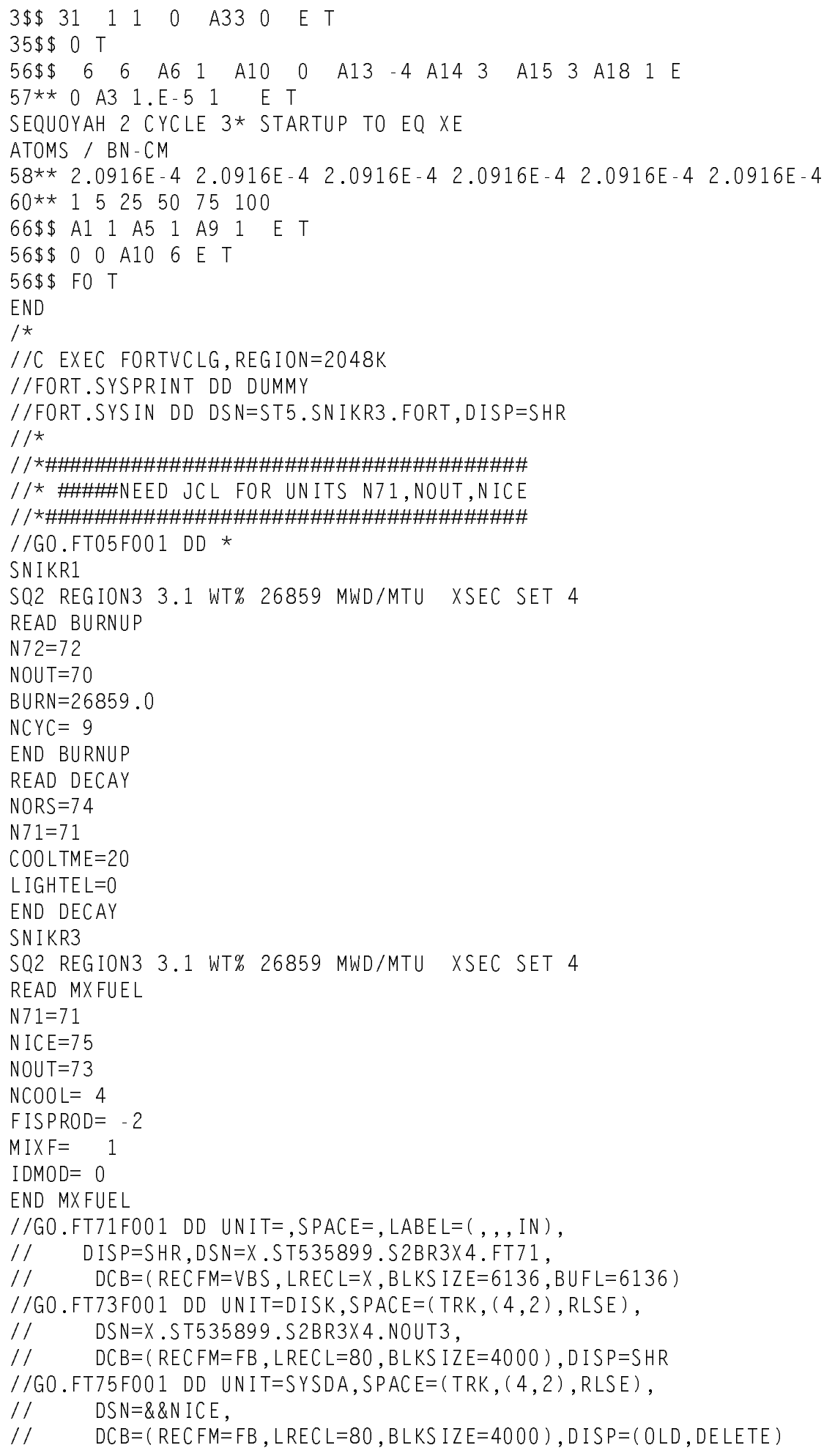




\section{Table D.4. CSASN input for cross-section sets with important actinides only}

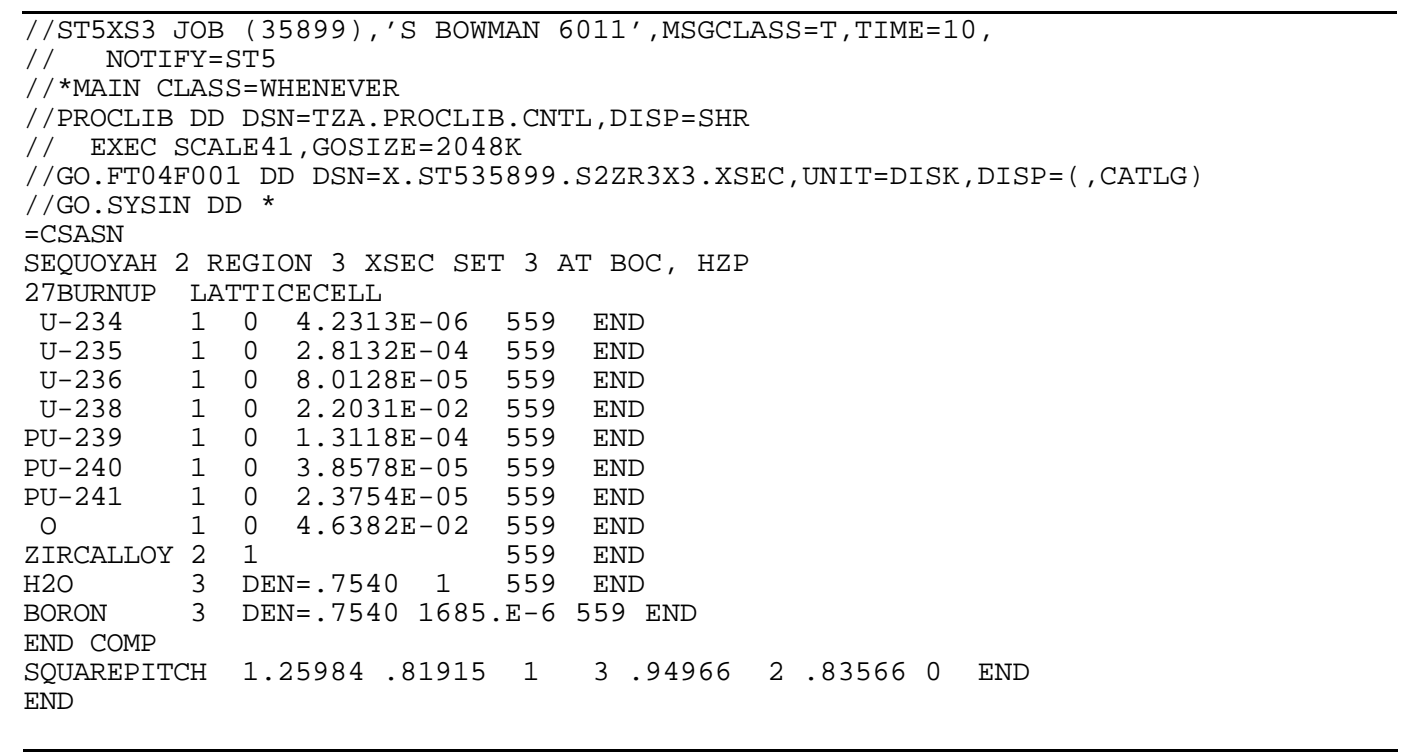


Table D.5. CSASN input for cross-section set 4

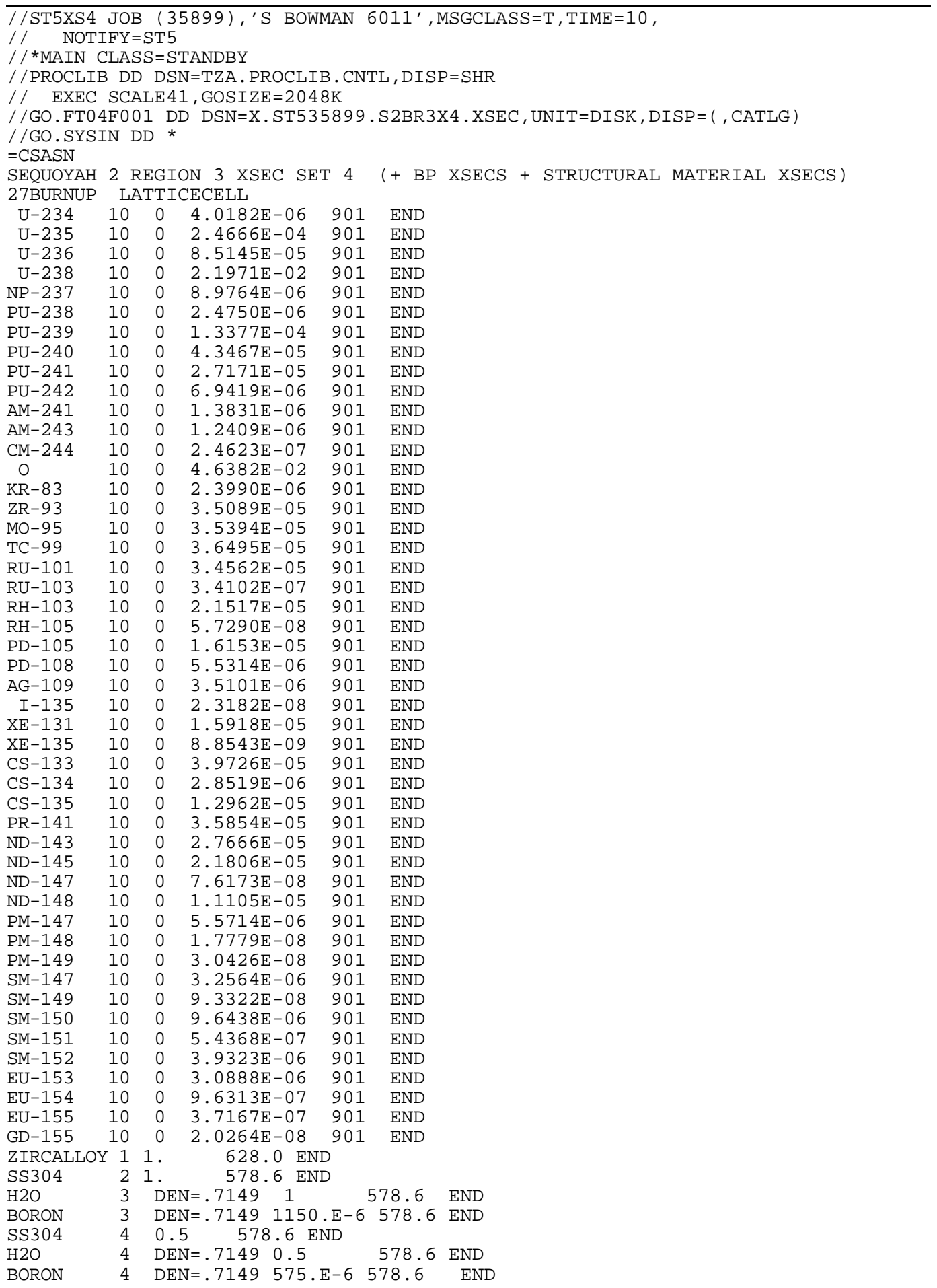


Table D.5. (continued)

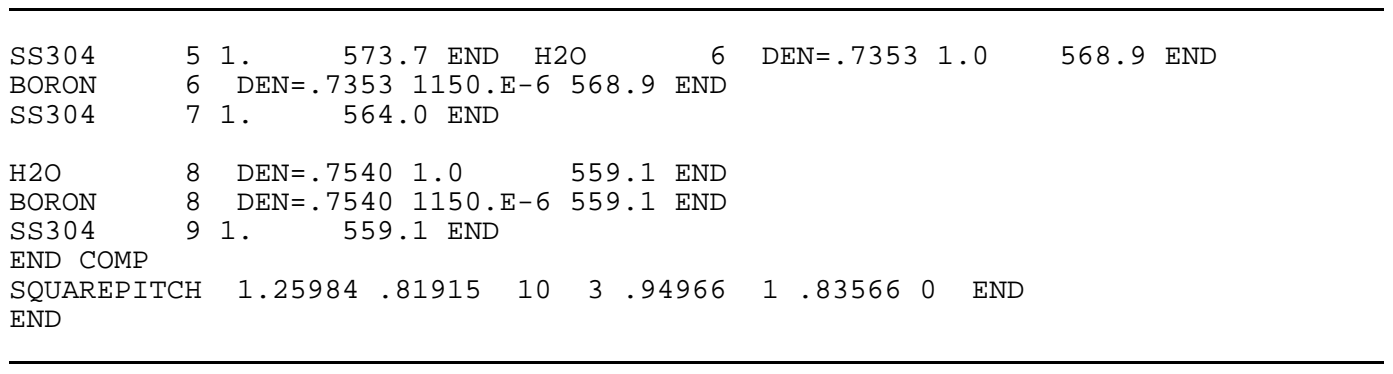




\section{Table D.6. WAX input for cross-section library generation}

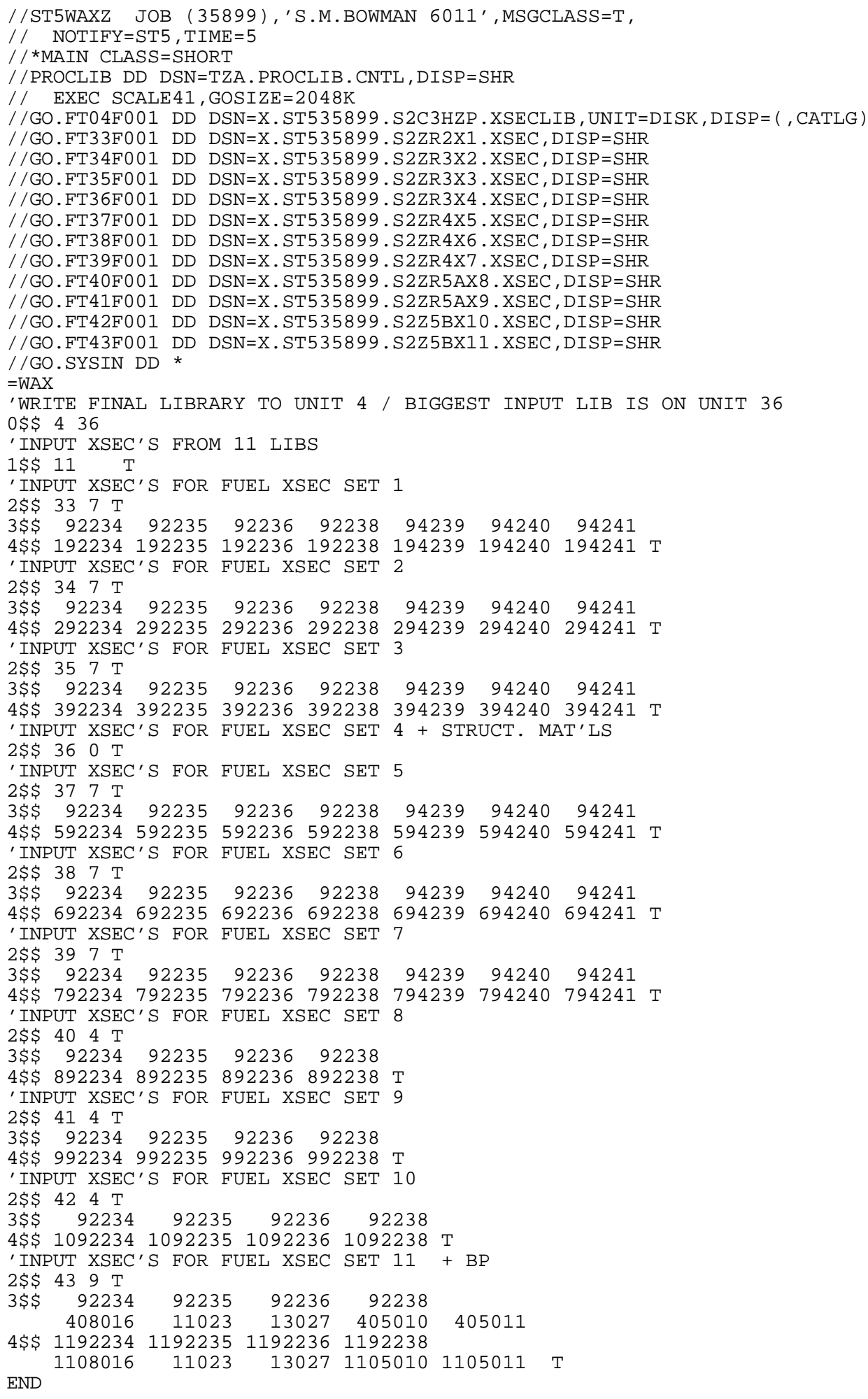


109

Table D.7. XSDRNPM input for assembly P17

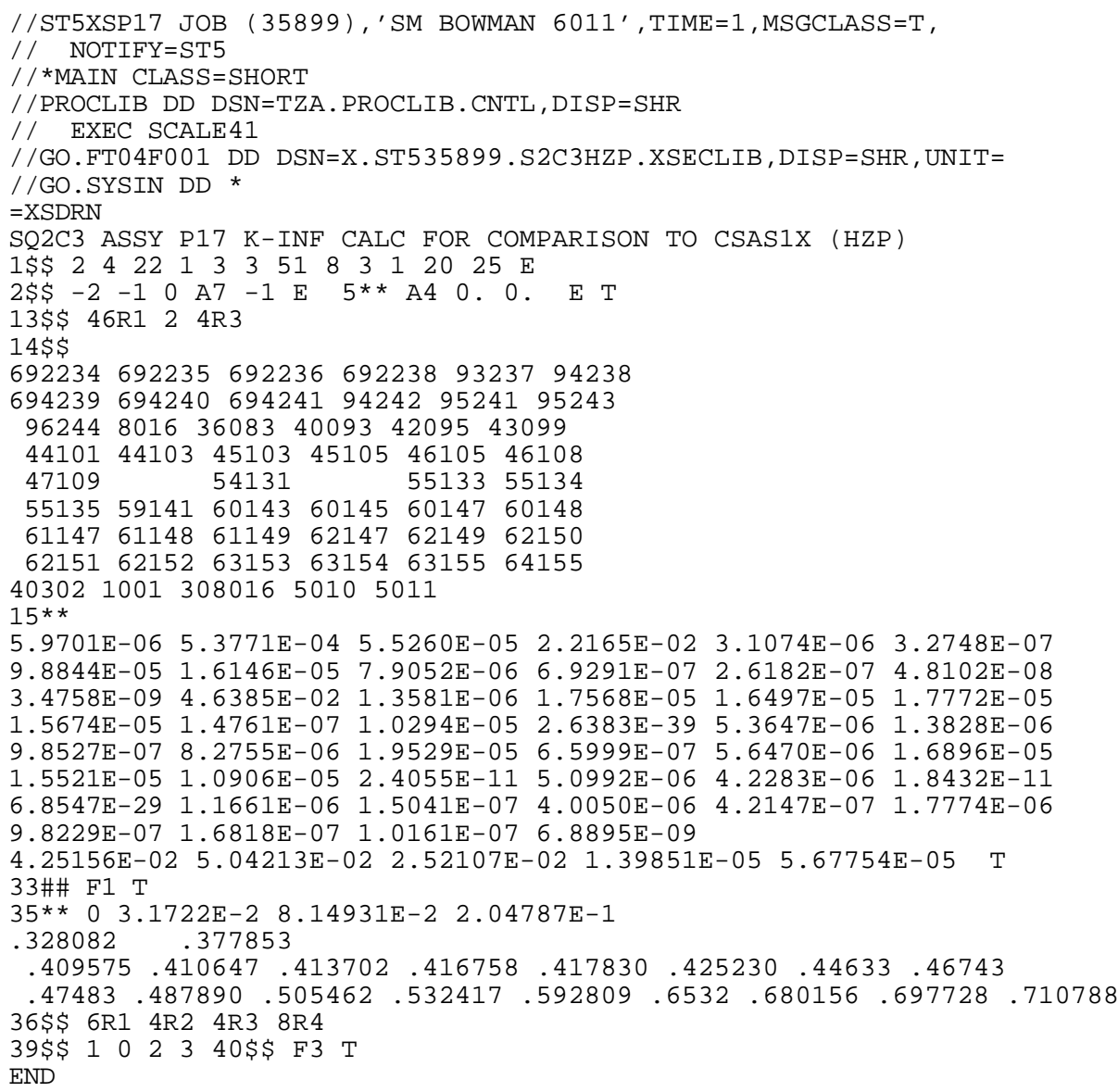


Table D.8. CSAS1X input for assembly P17

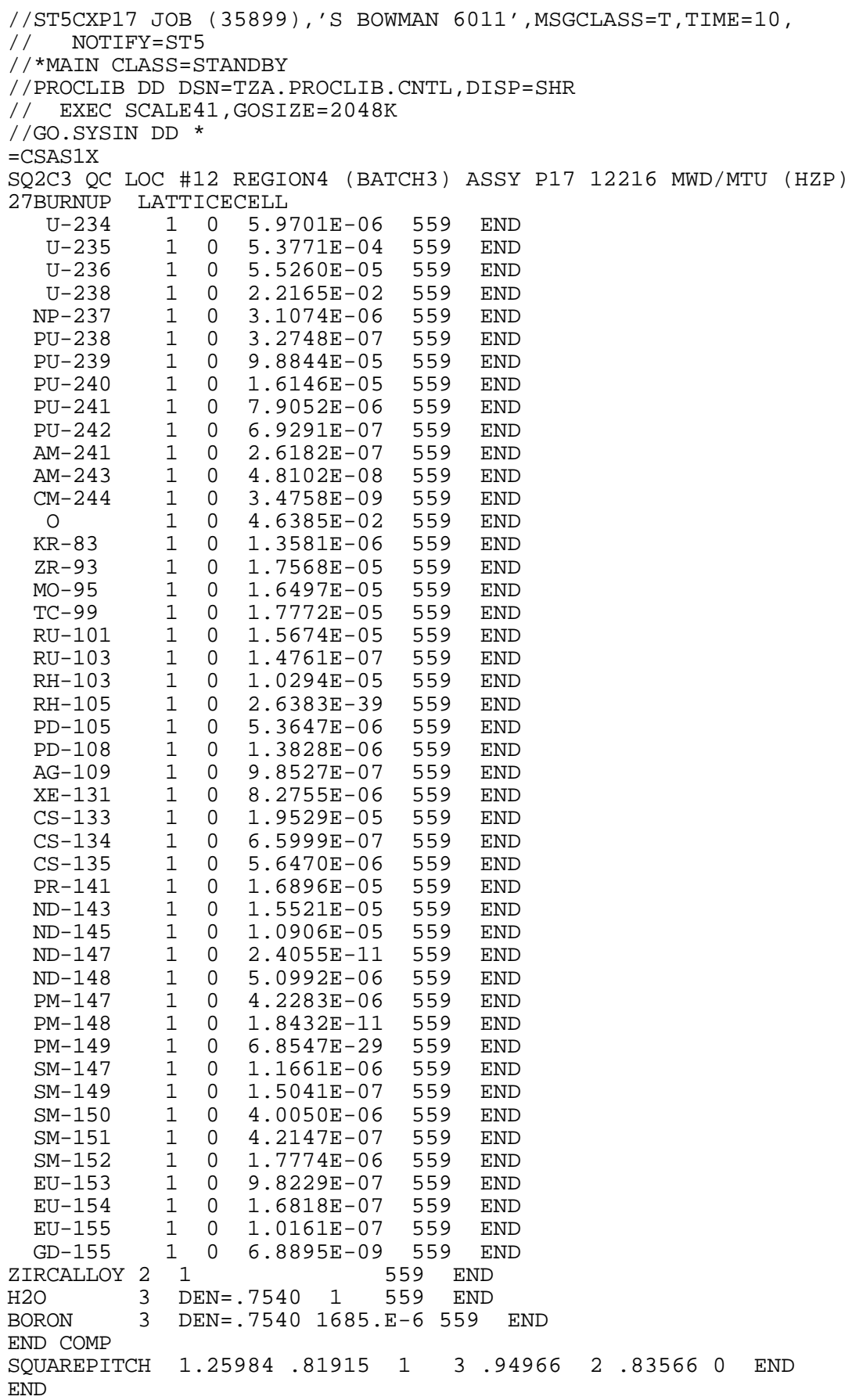


Table D.9. KENO V.a input file for BOC, HZP

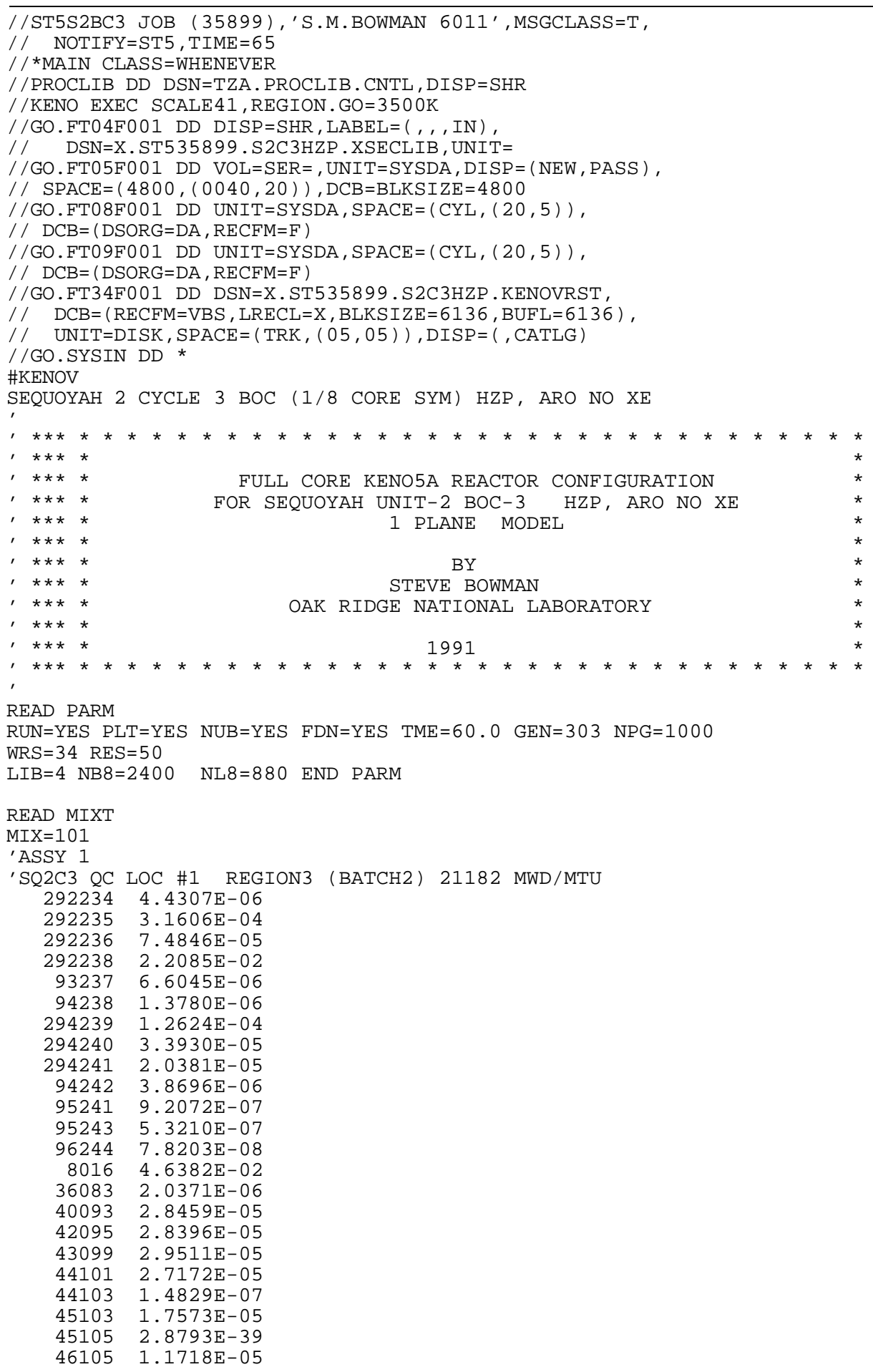


112

Table D.9. (continued)

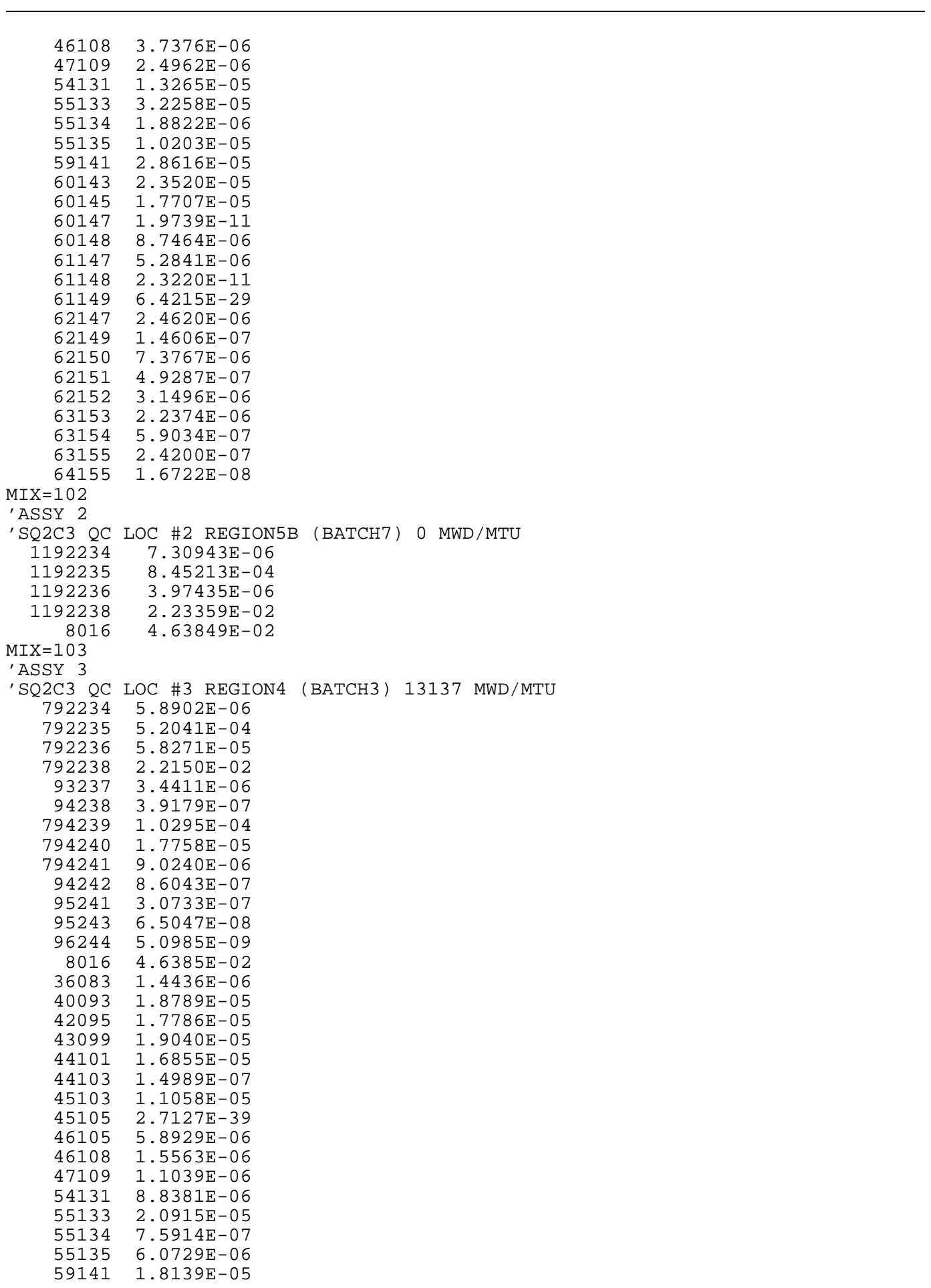


Table D.9. (continued)

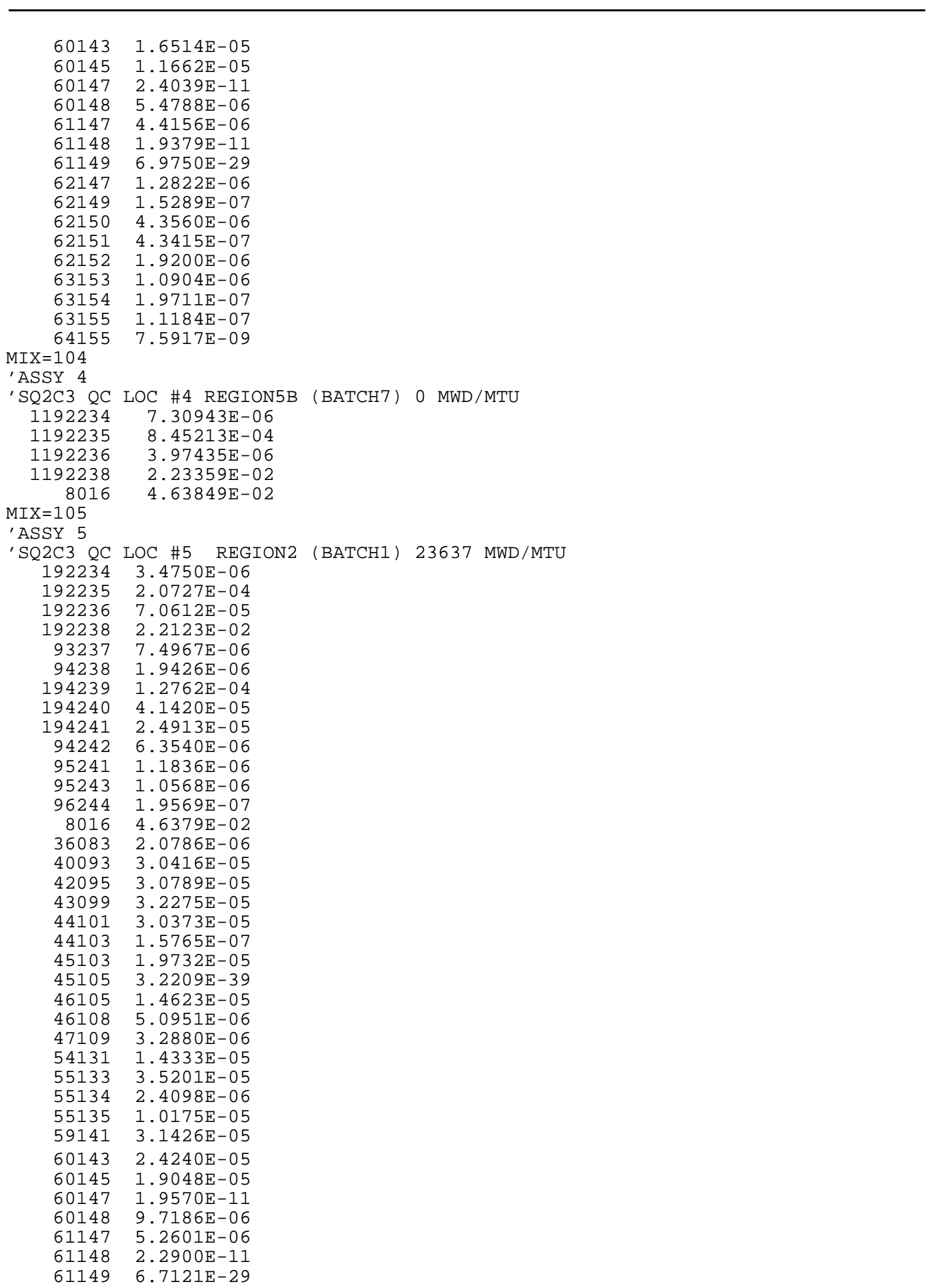


114

Table D.9 (continued)

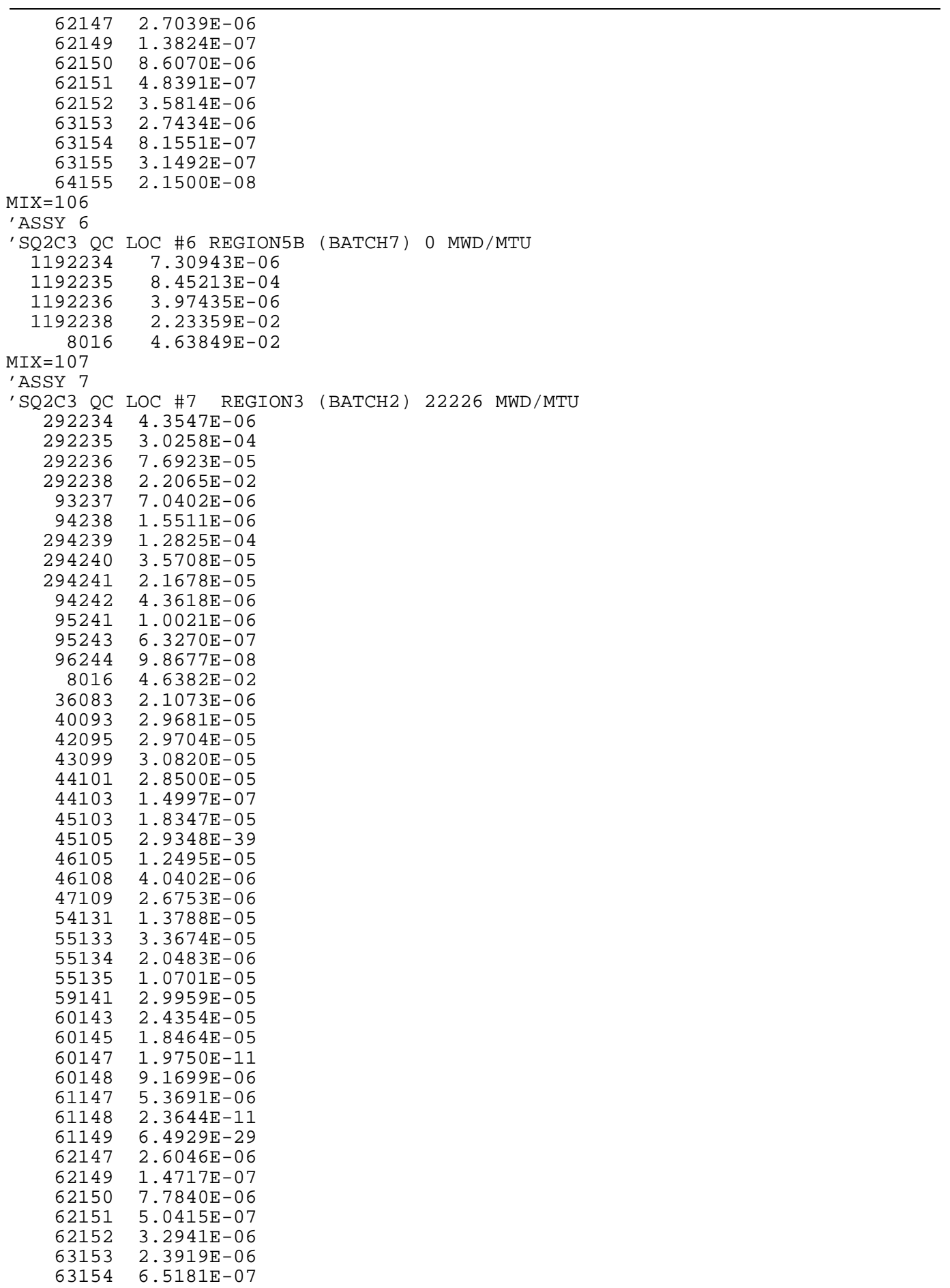


Table D.9. (continued)

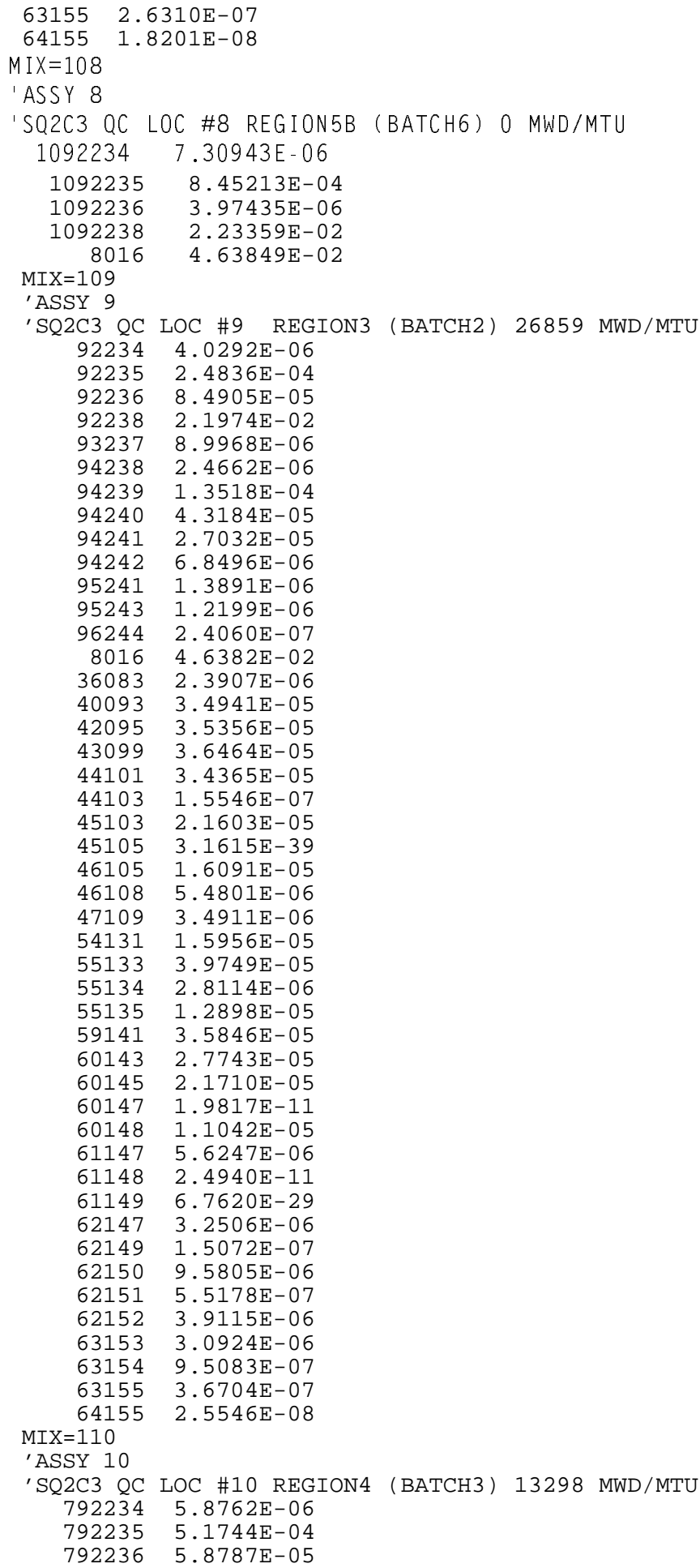


116

Table D.9 (continued)

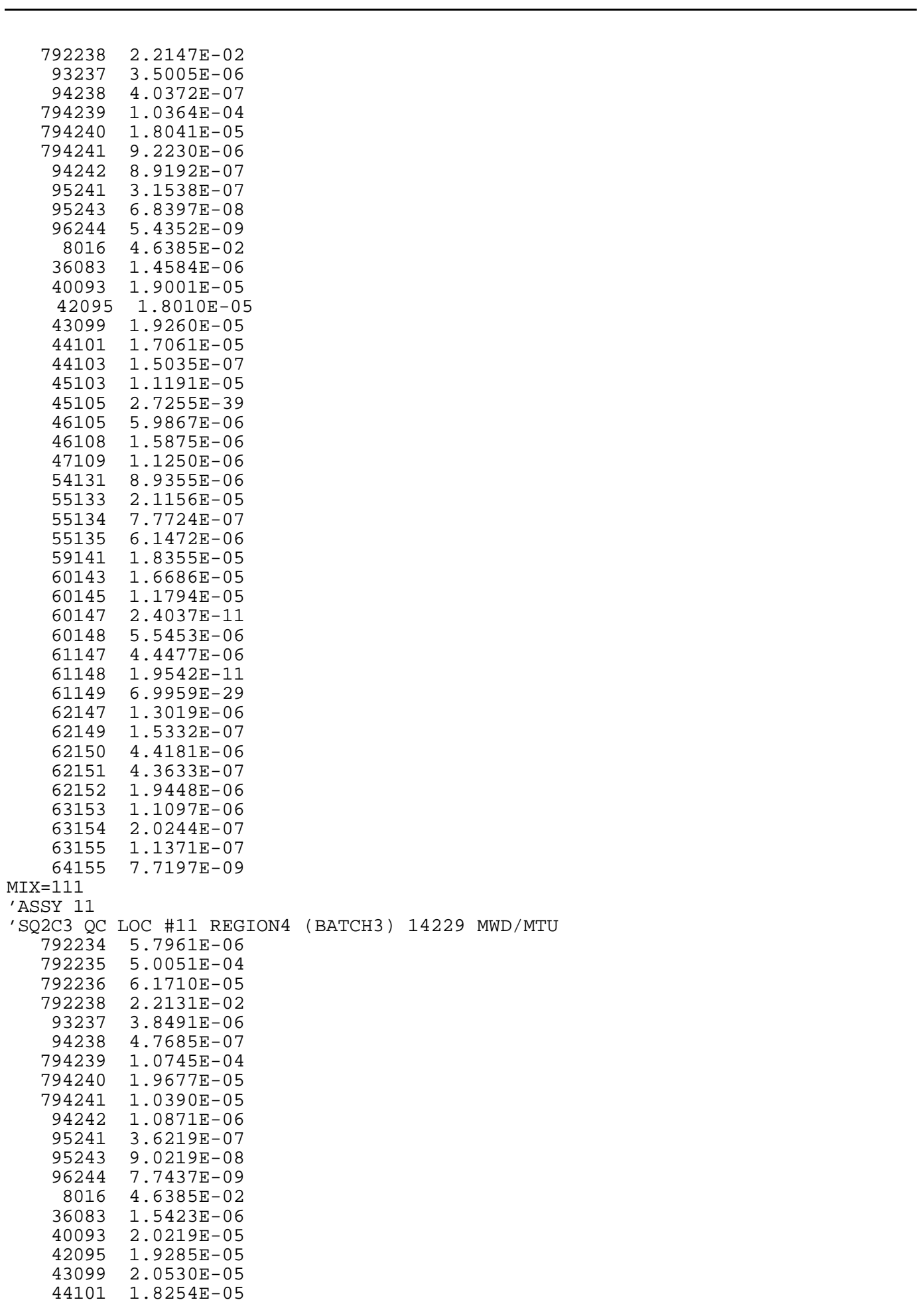


Table D.9 (continued)

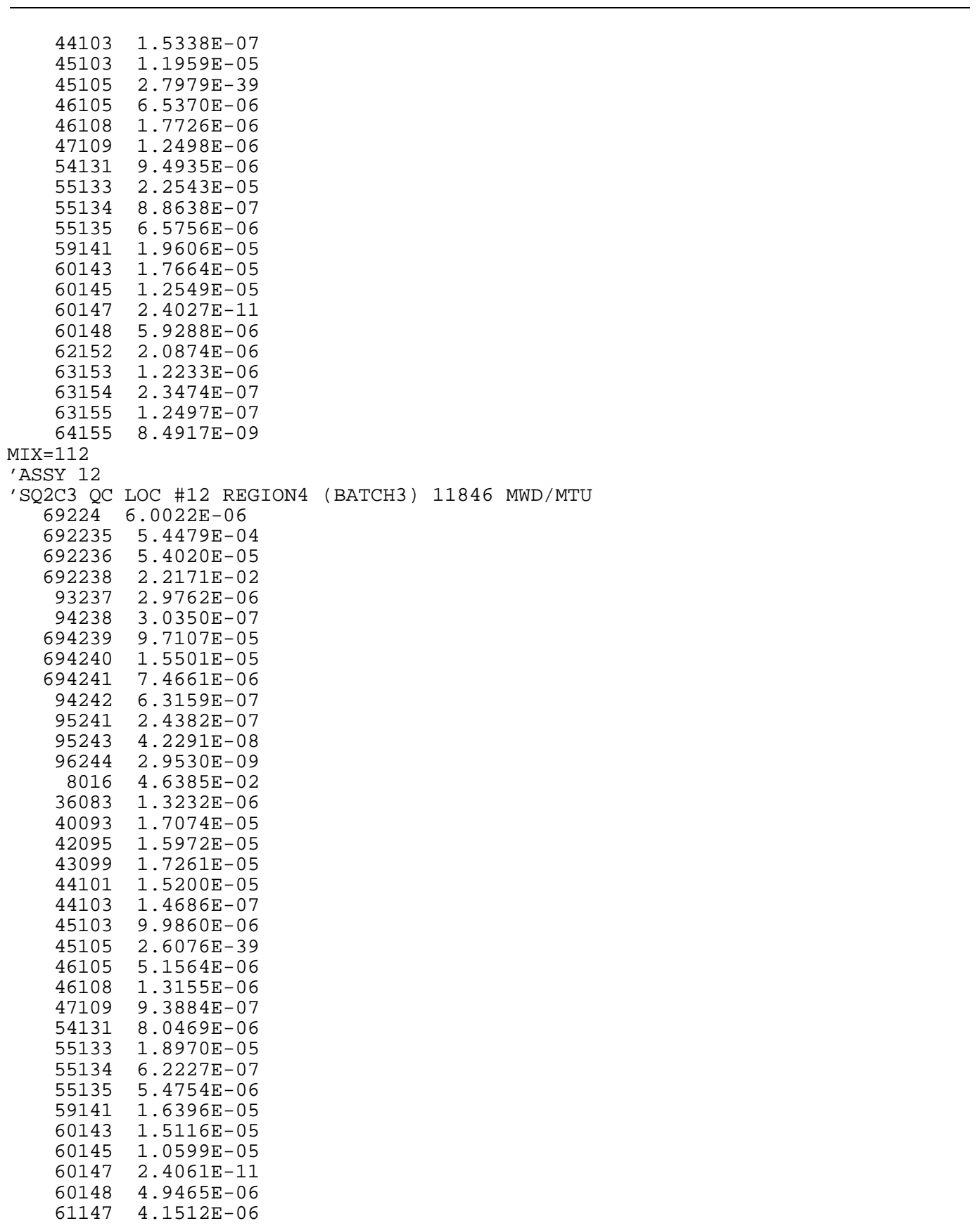


118

Table D.9 (continued)

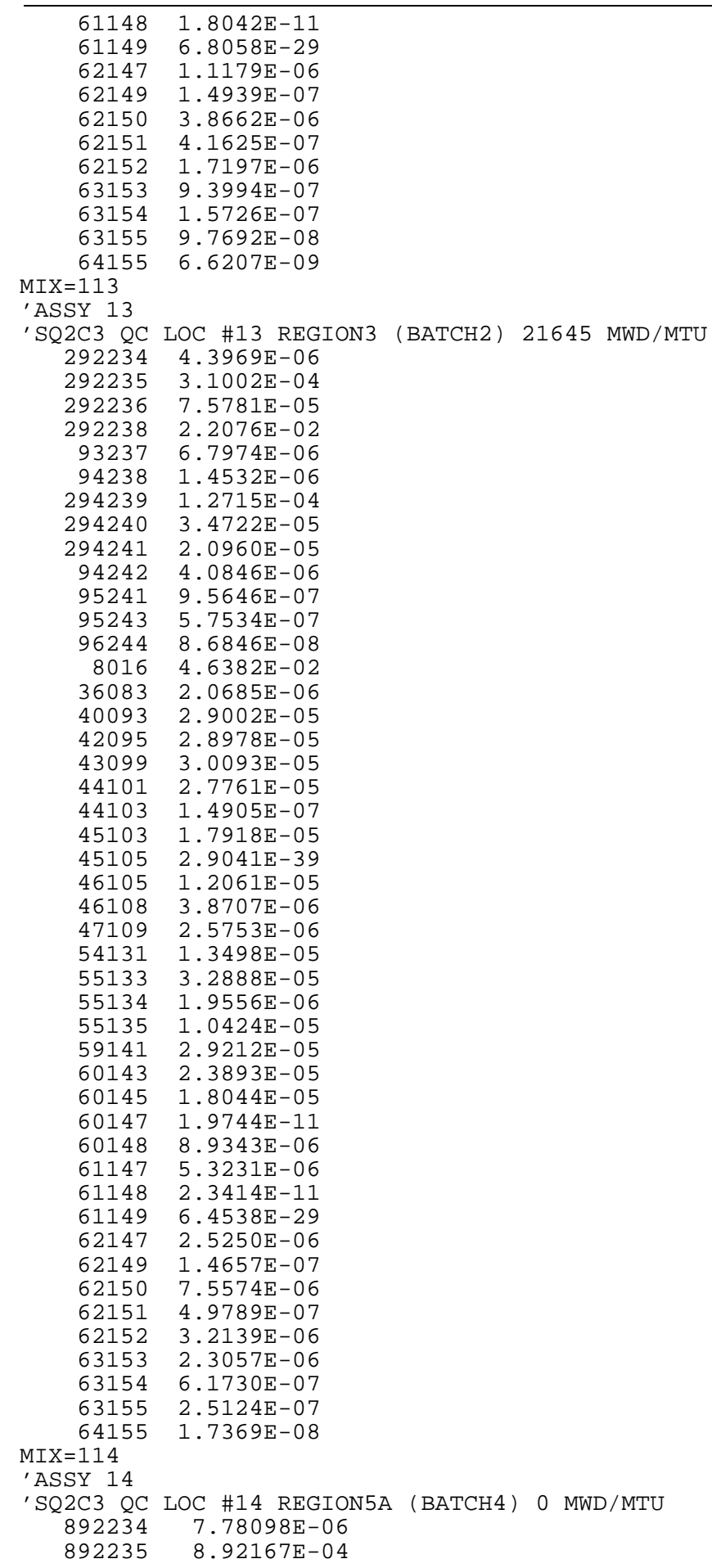


Table D.9 (continued)

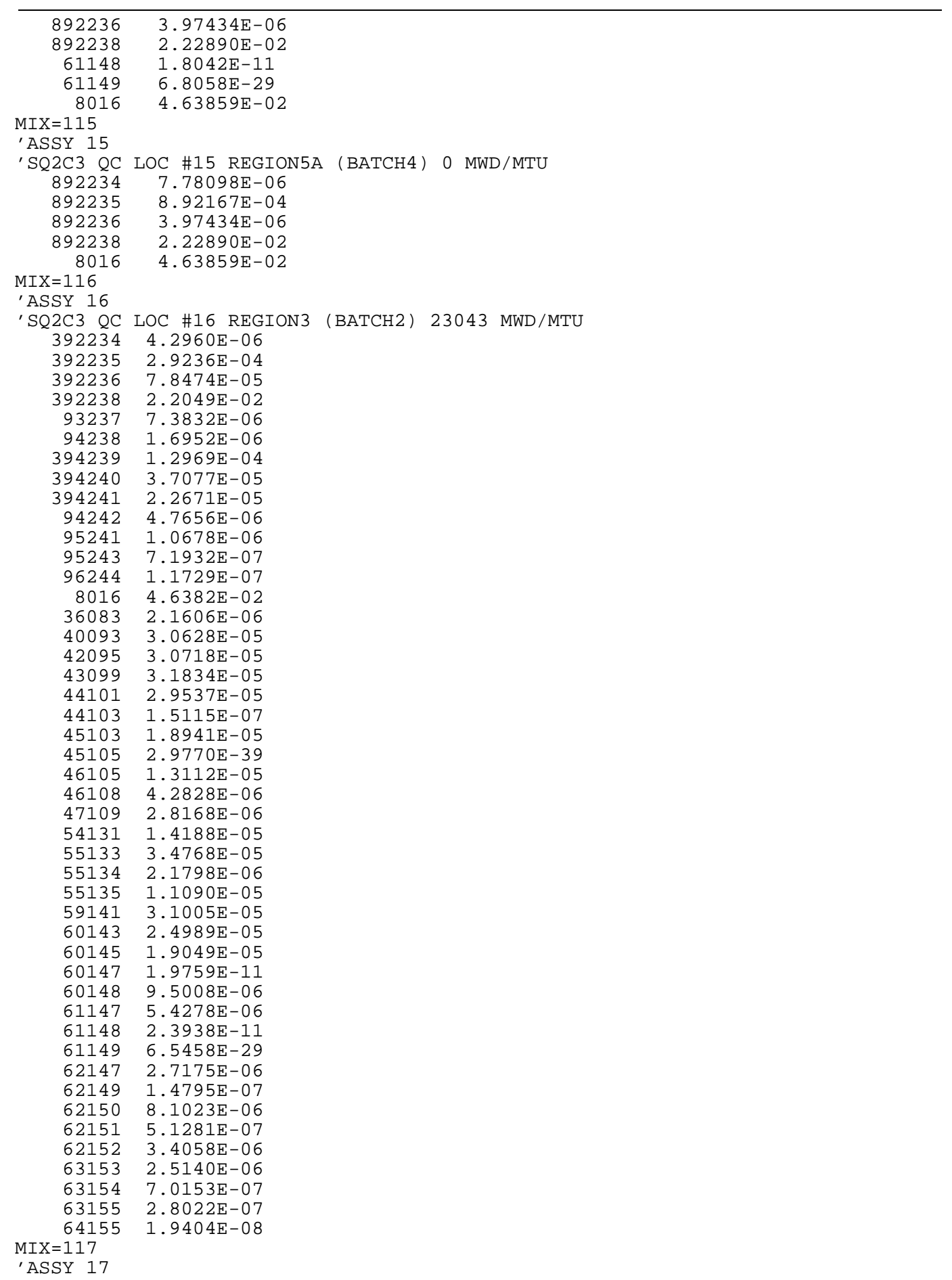


Table D.9 (continued)

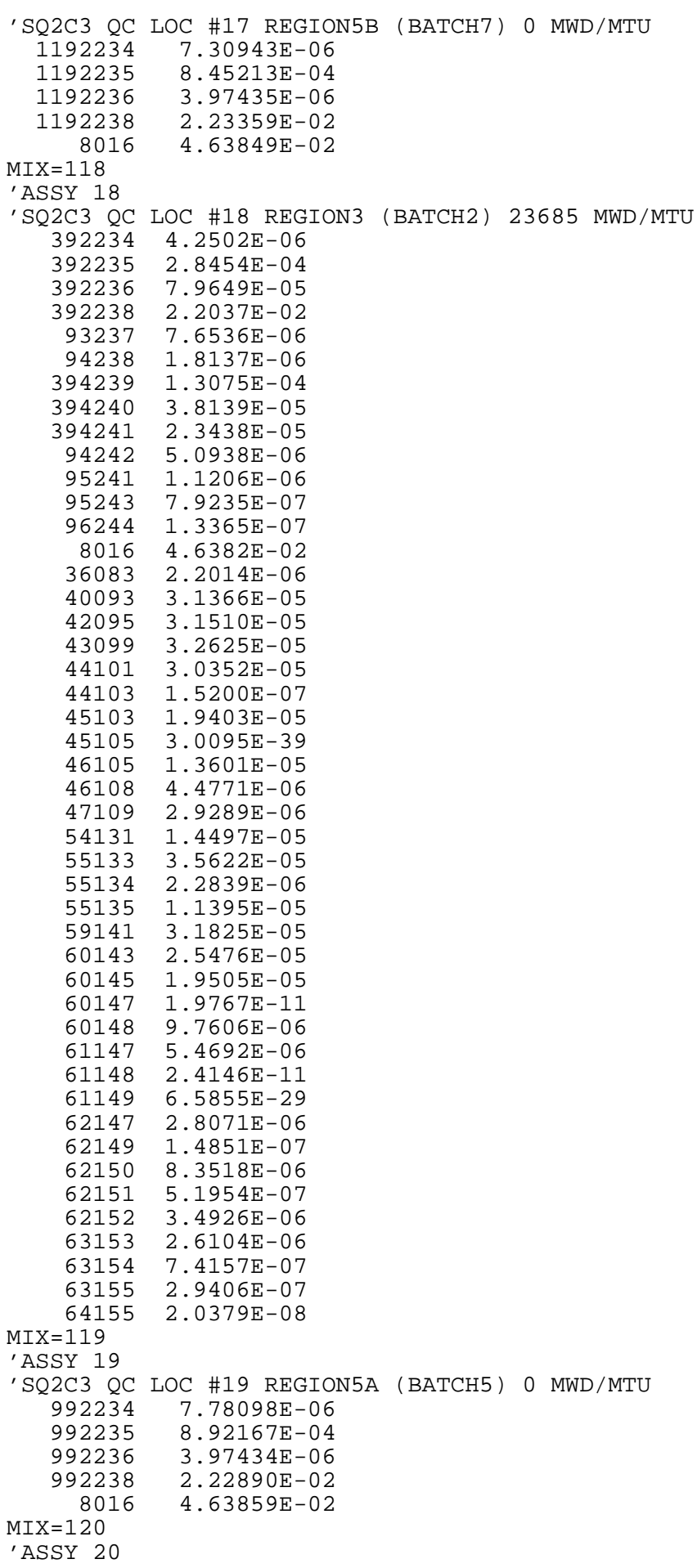


121

Table D.9 (continued)

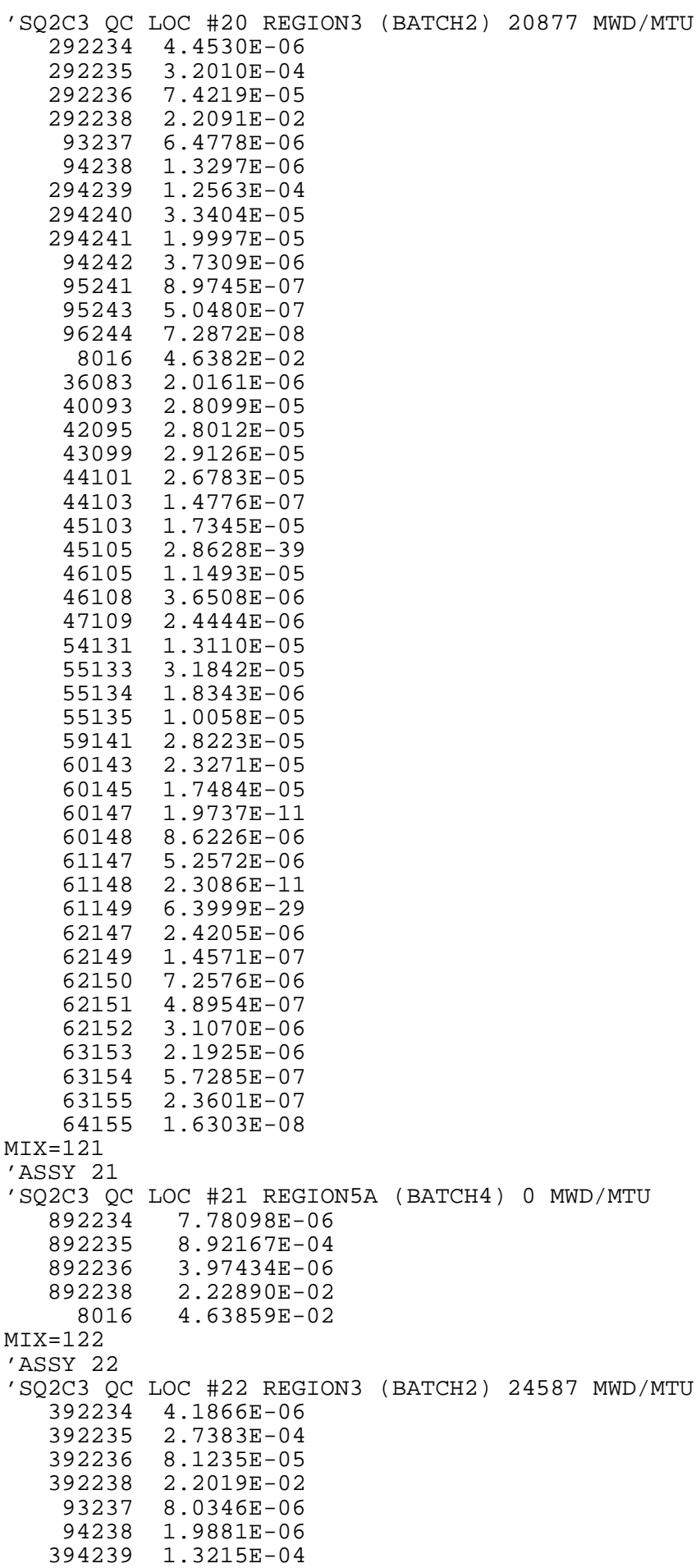


122

Table D.9 (continued)

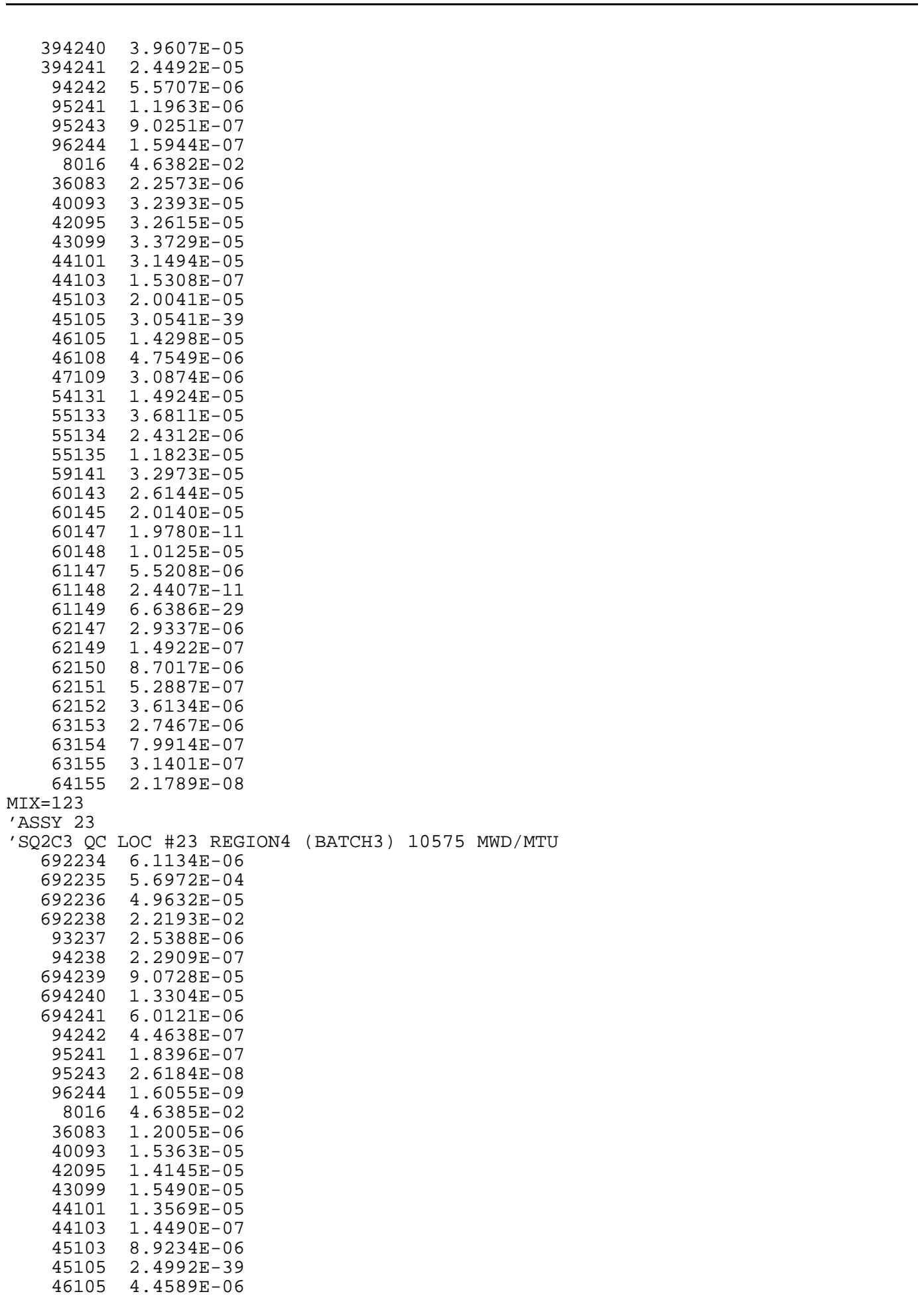


123

Table D.9 (continued)

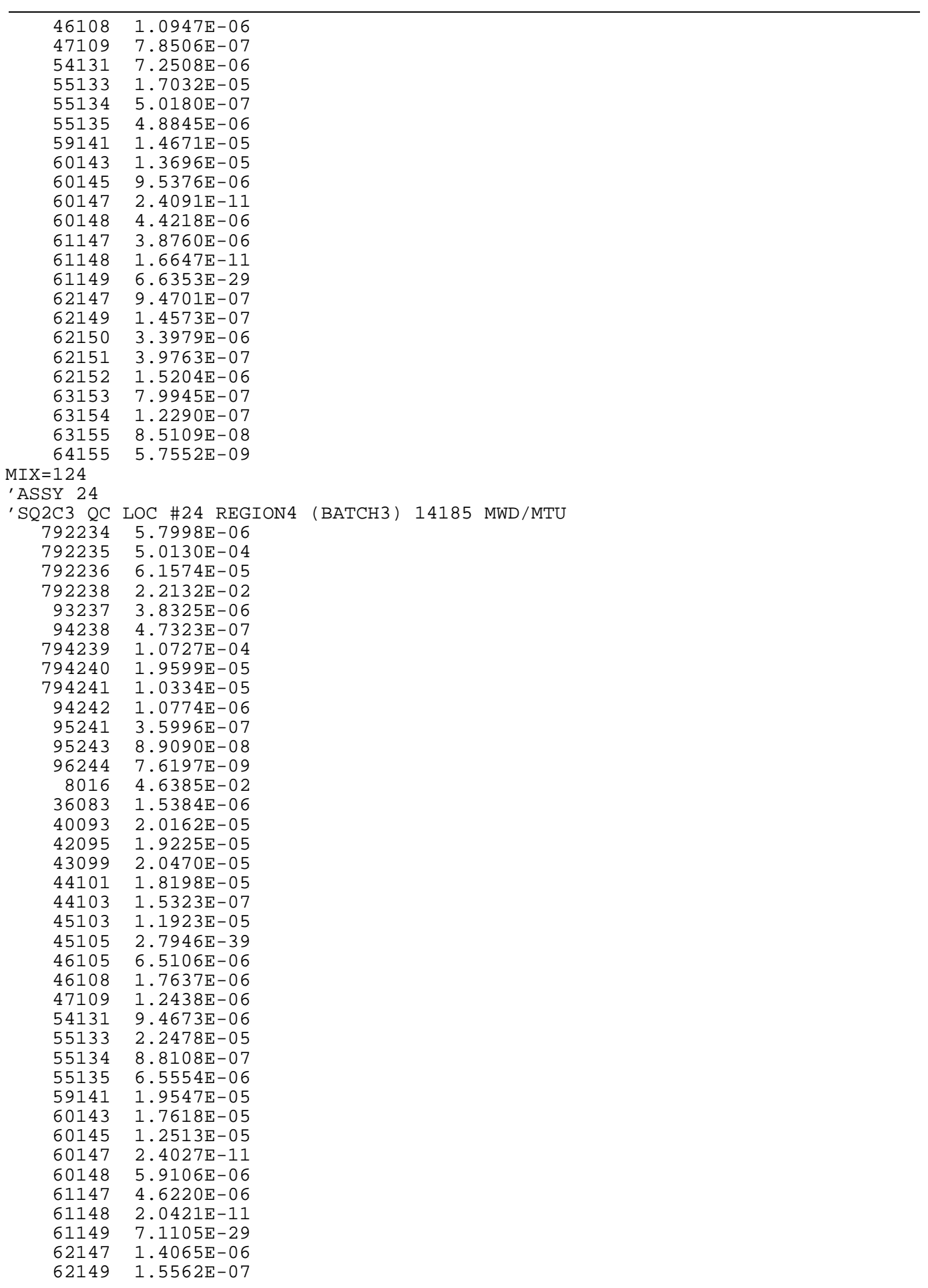


124

Table D.9 (continued)

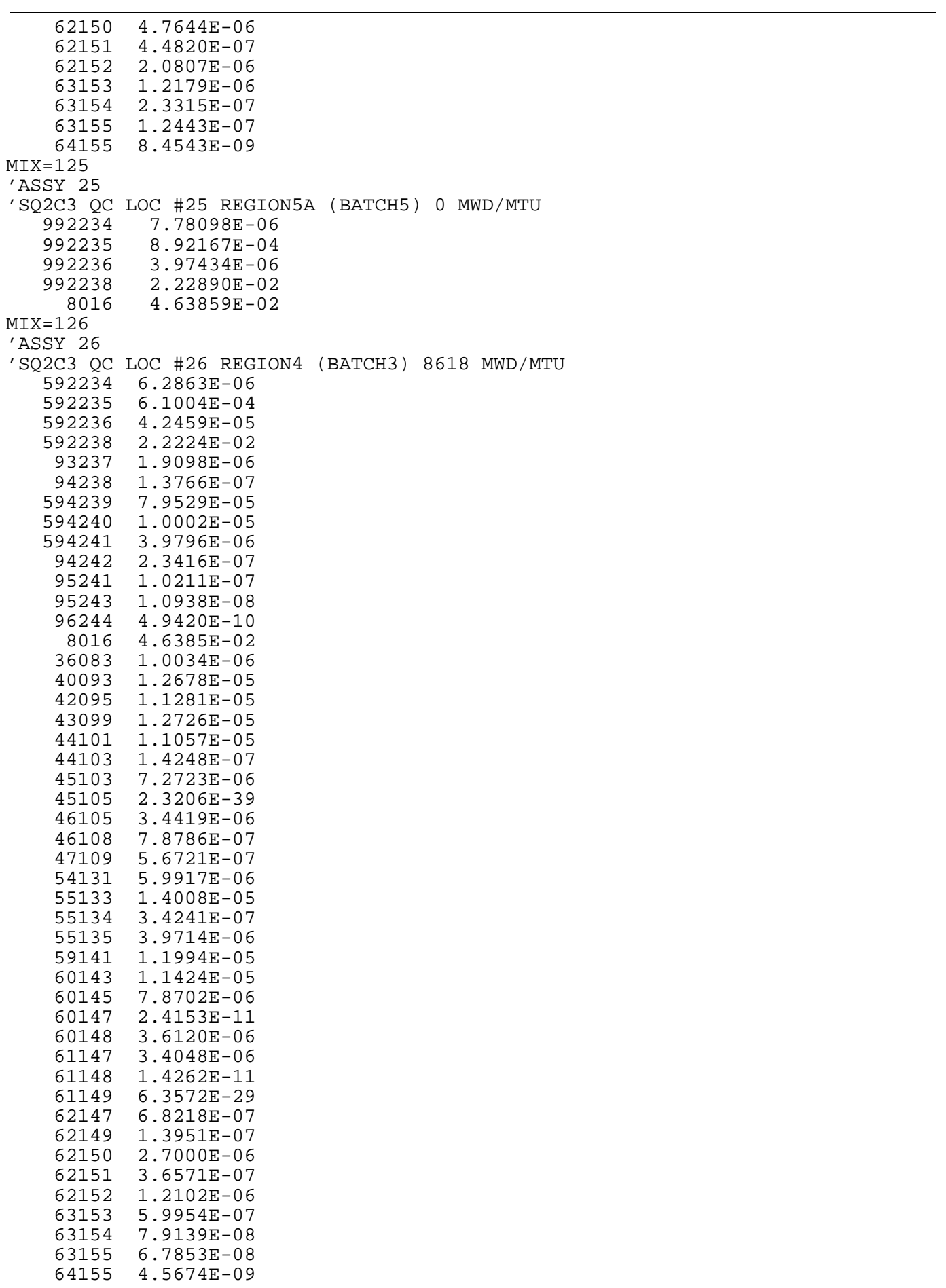


Table D.9 (continued)

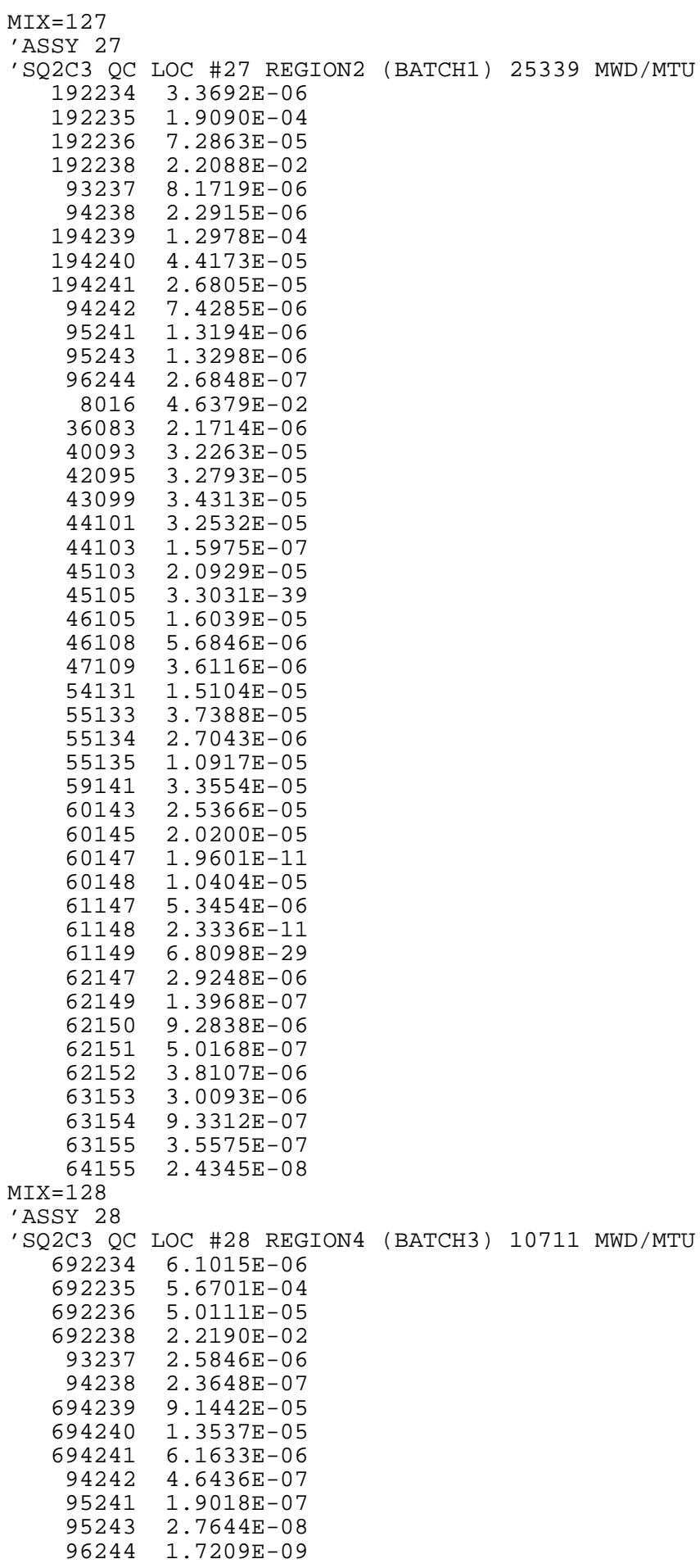


126

Table D.9 (continued)

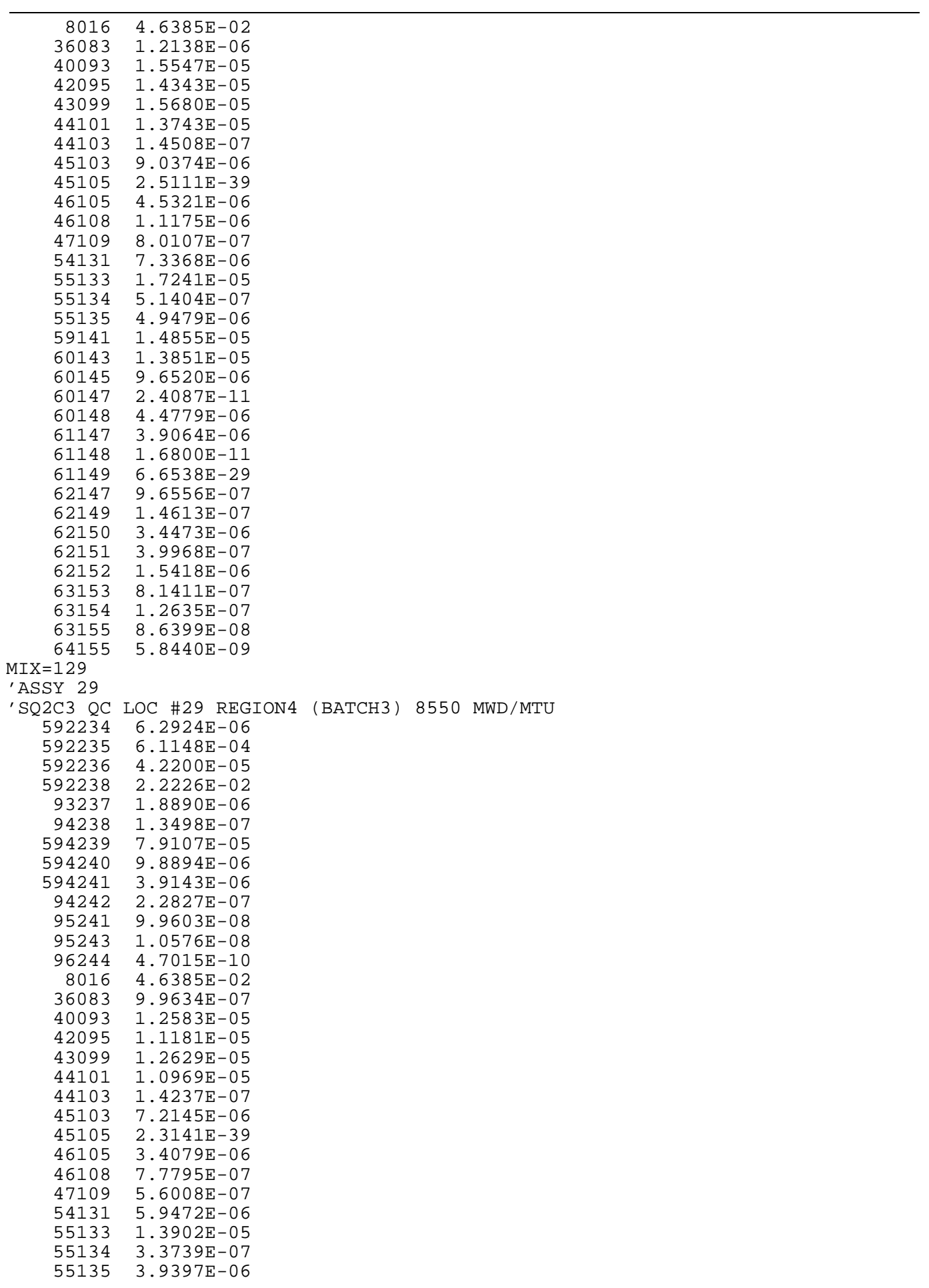


127

Table D.9 (continued)

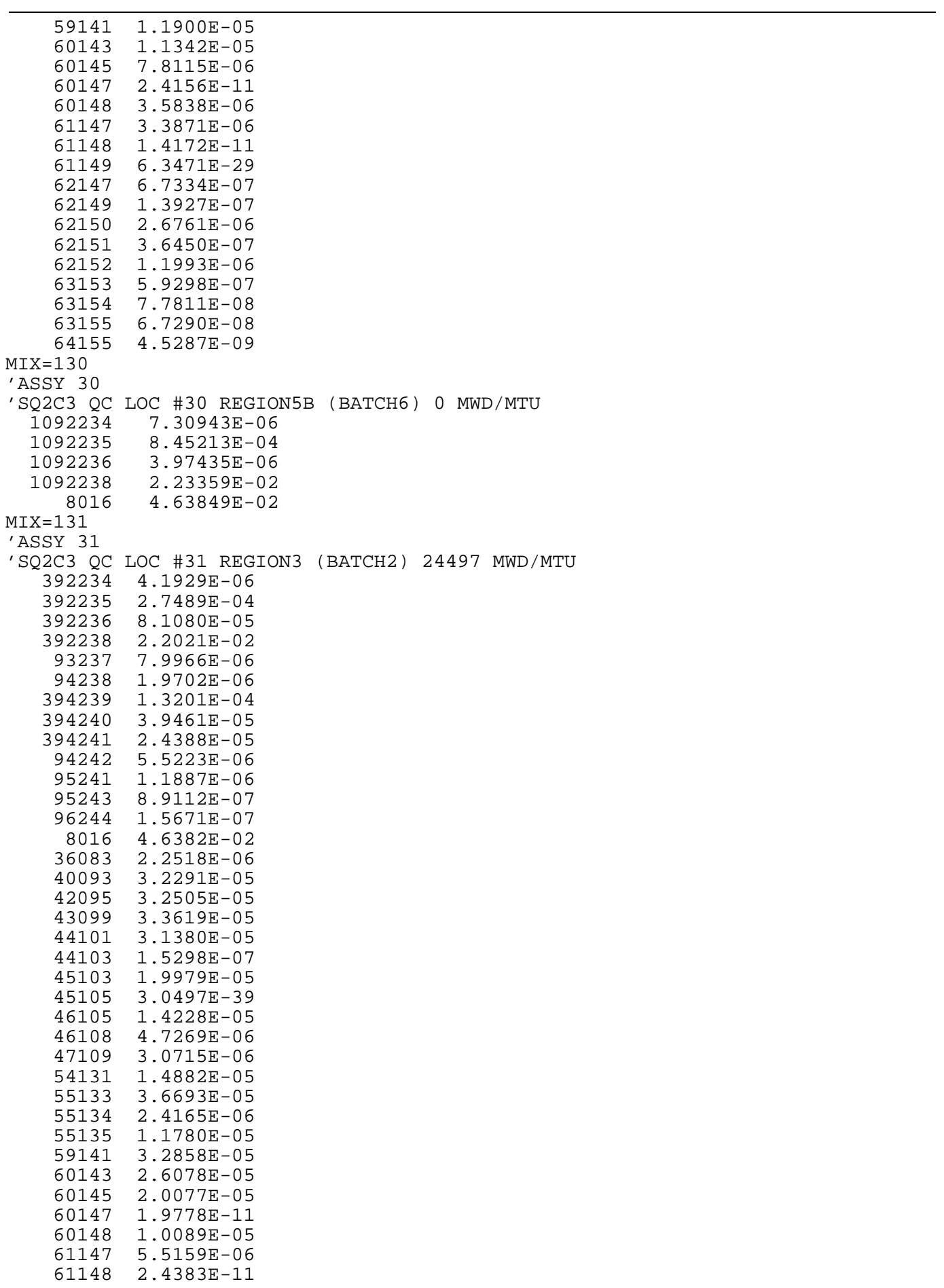


Table D.9. (continued)

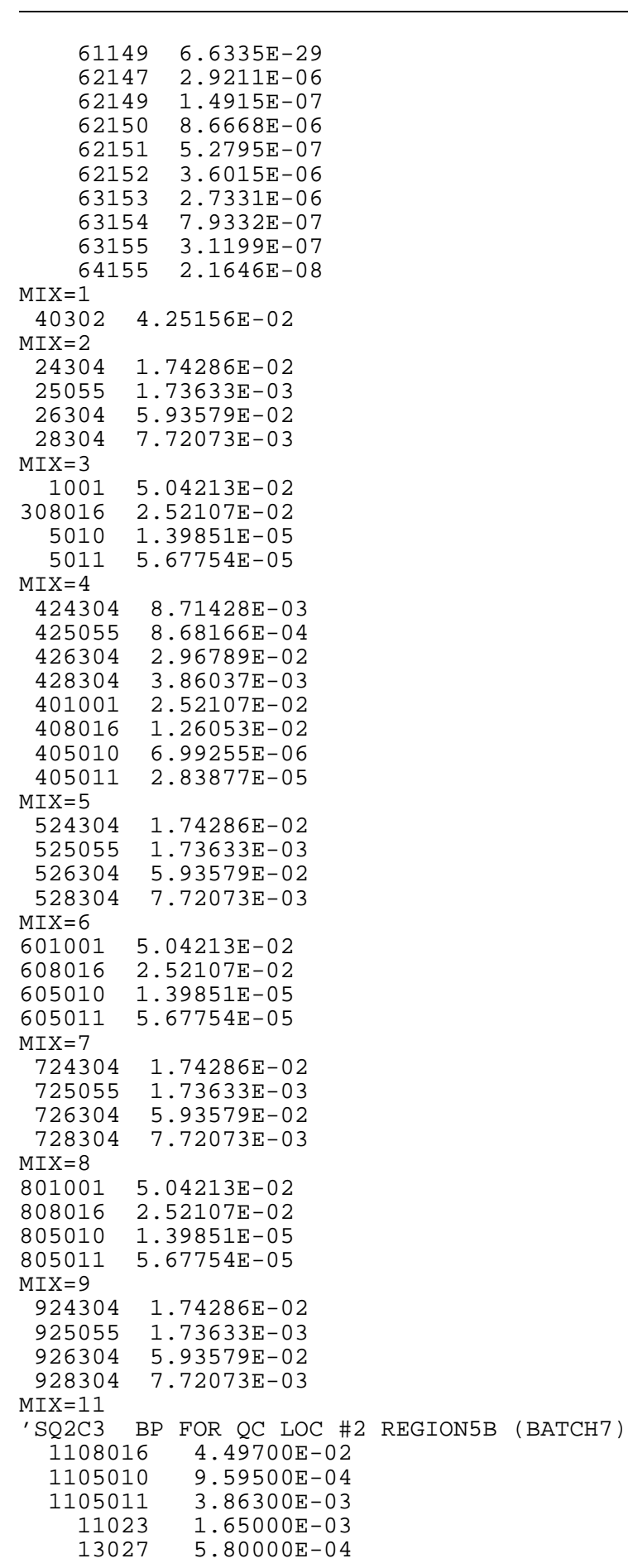




\section{Table D.9 (continued)}

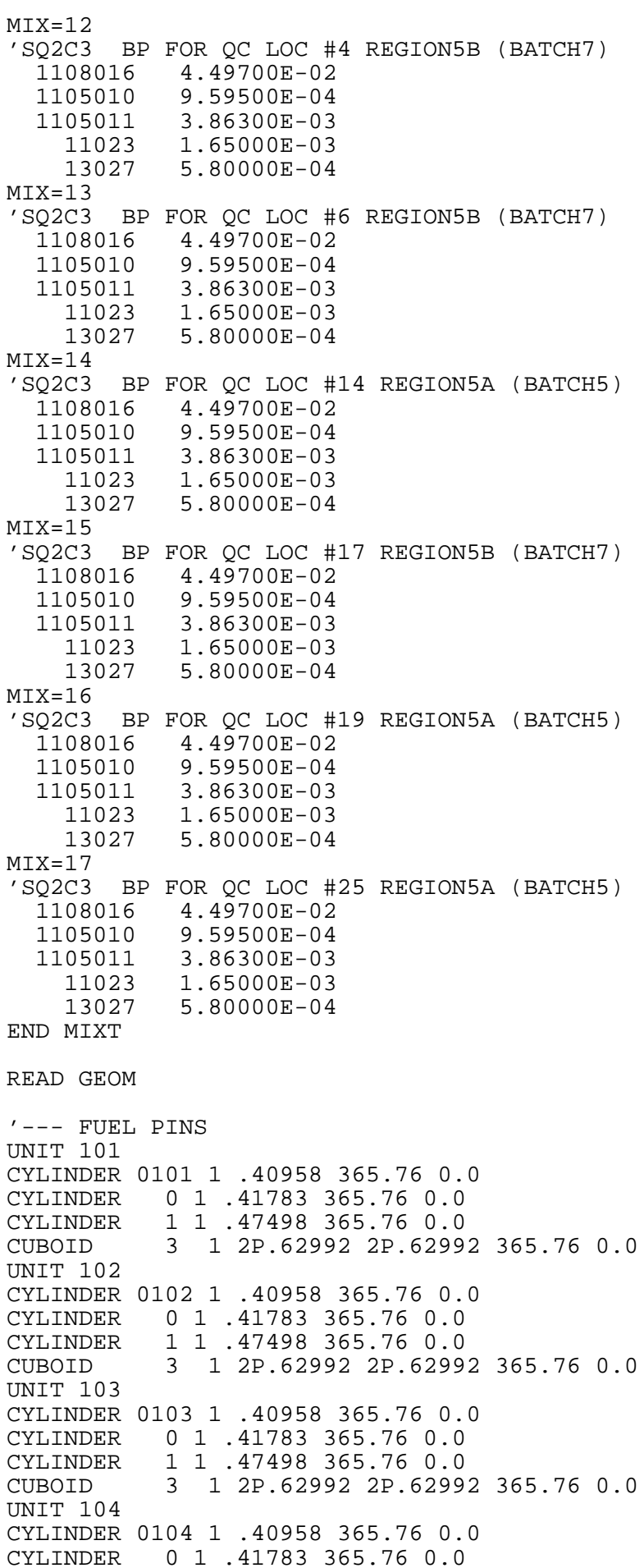




\section{Table D.9 (continued)}

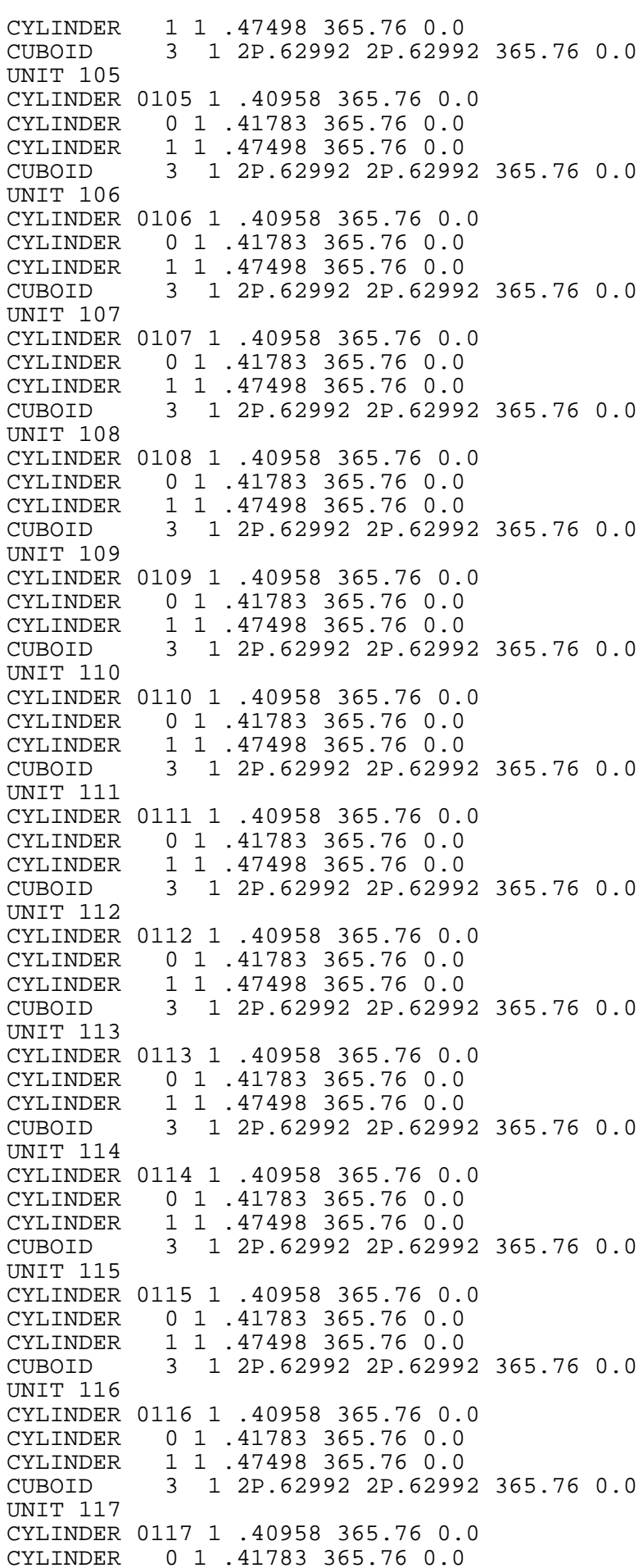


131

\section{Table D.9 (continued)}

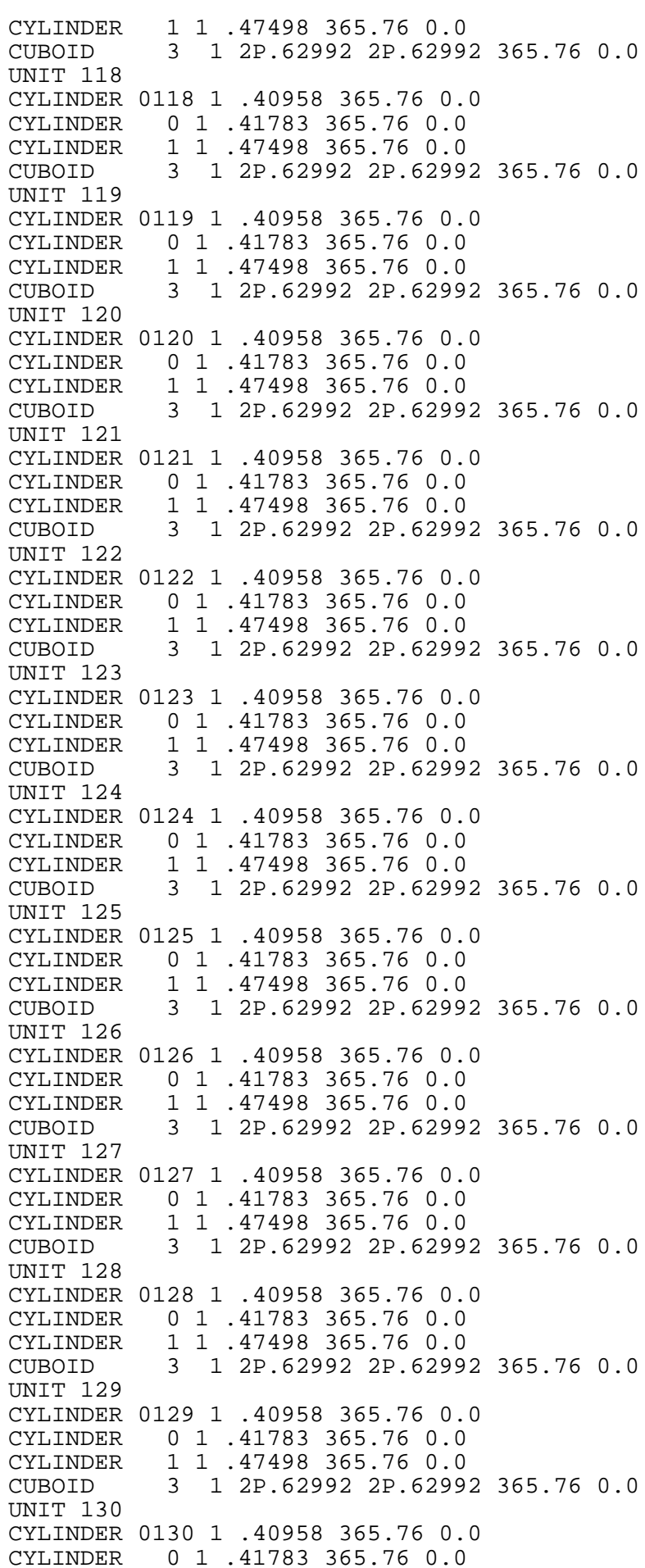




\section{Table D.9 (continued)}

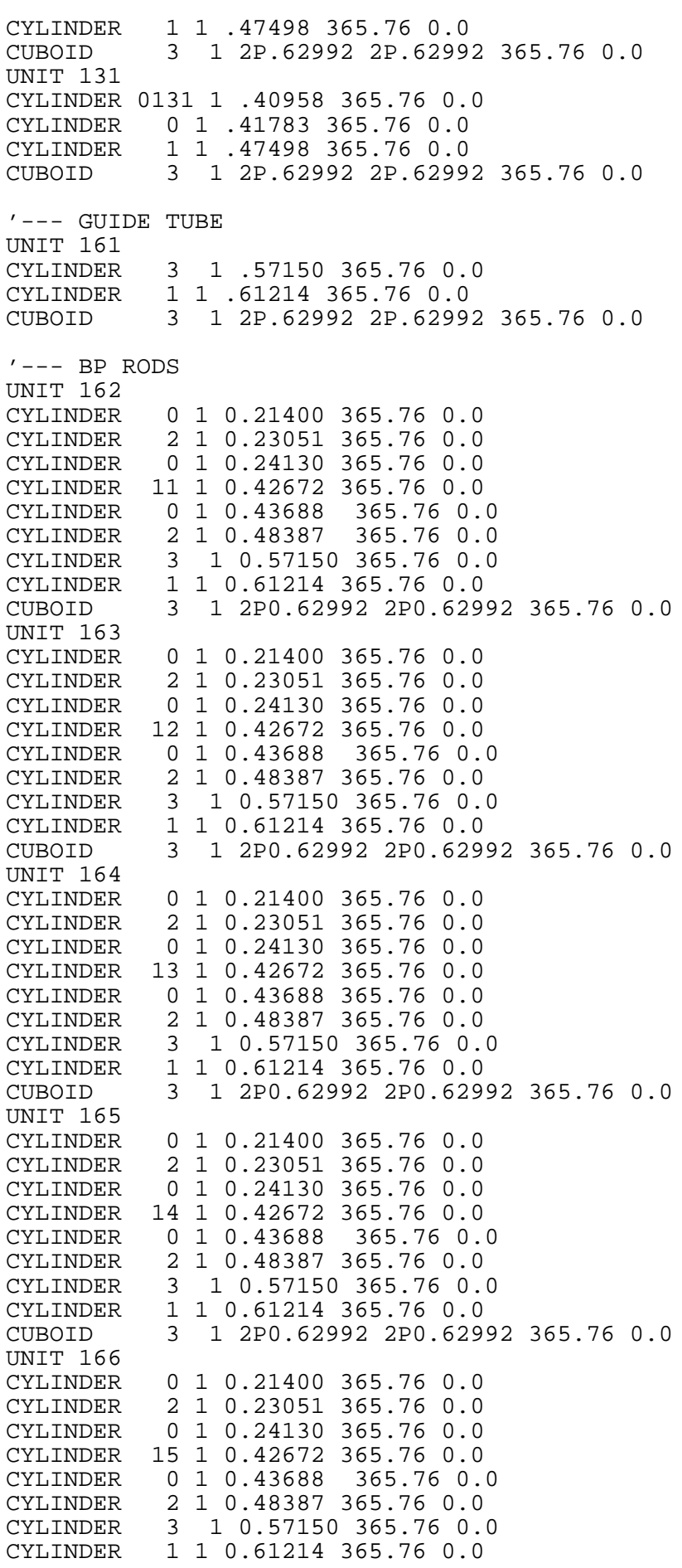




\section{Table D.9 (continued)}

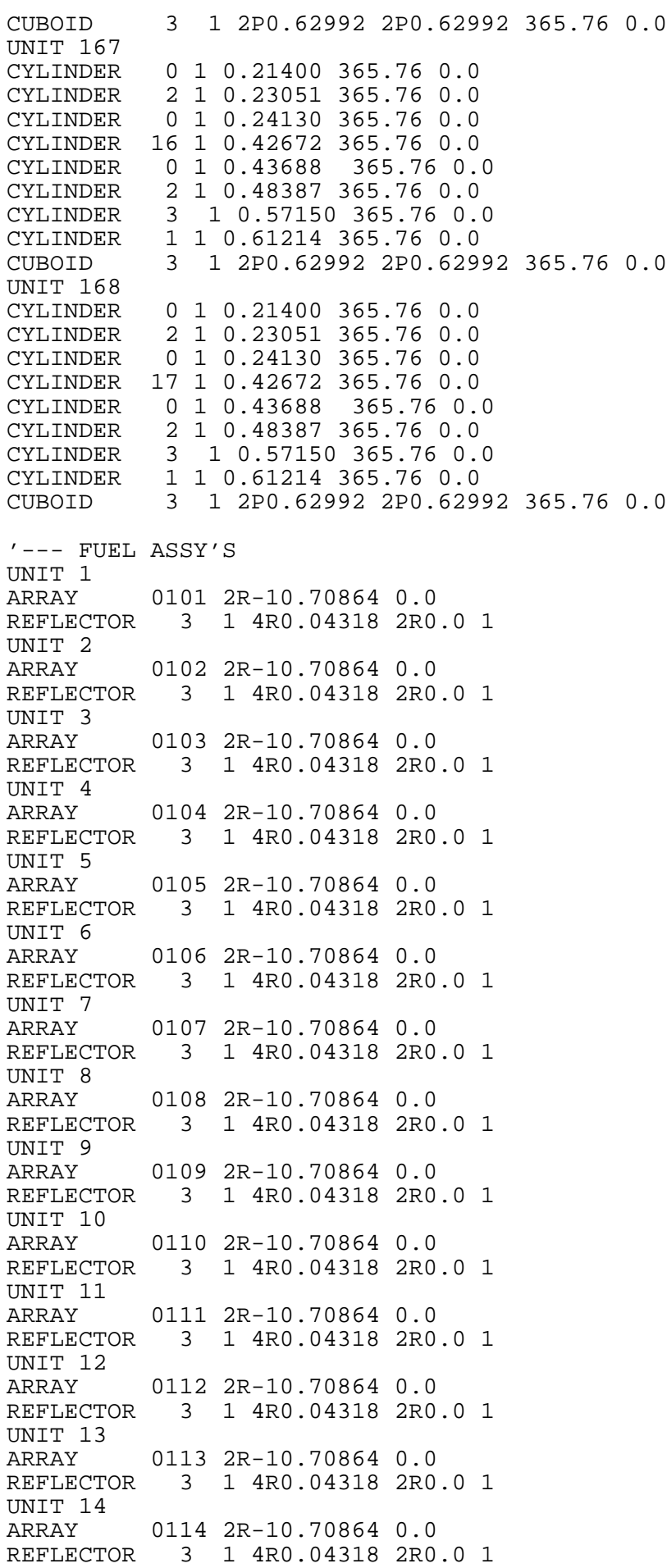


134

Table D.9 (continued)

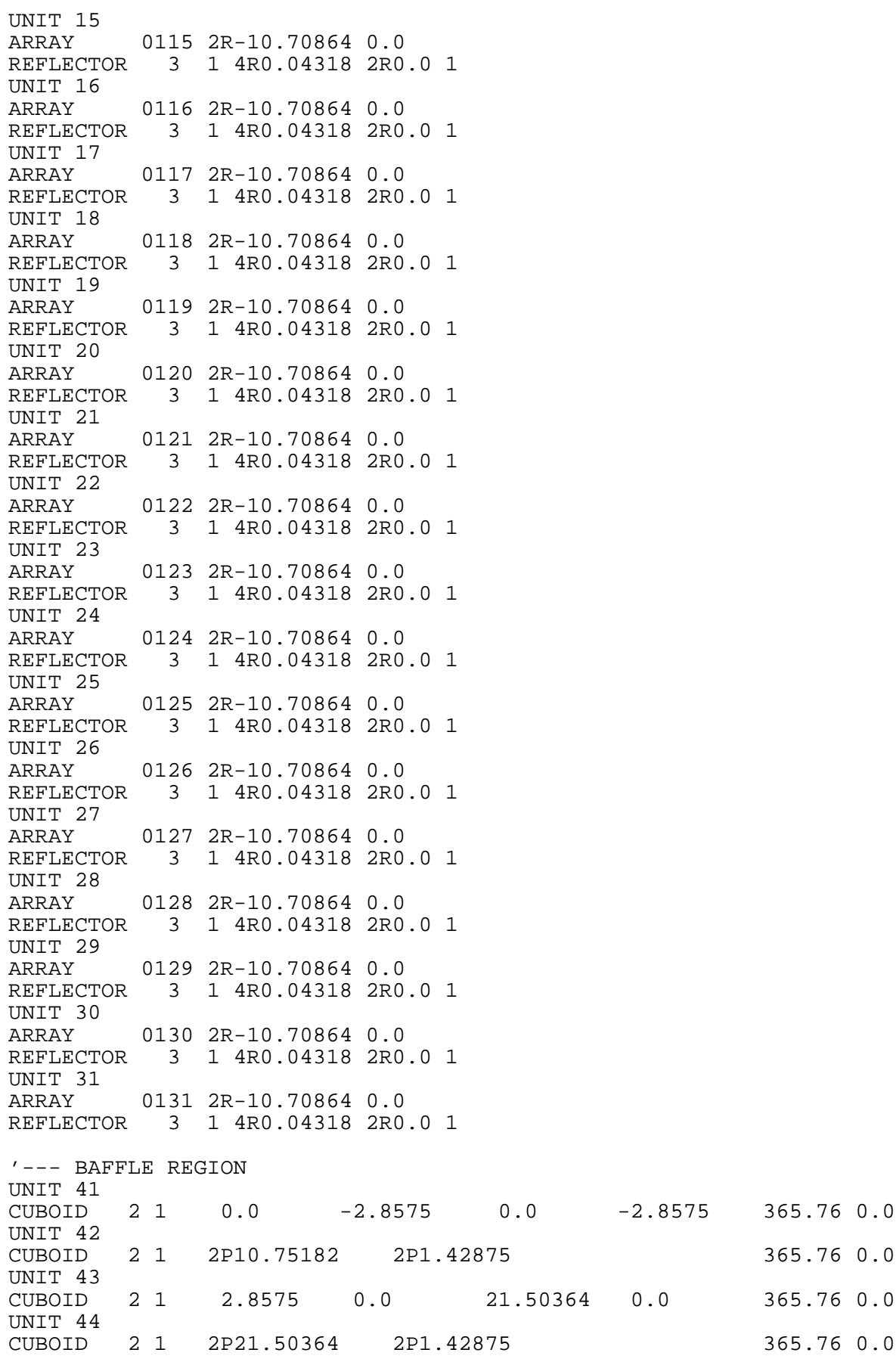


135

Table D.9 (continued)

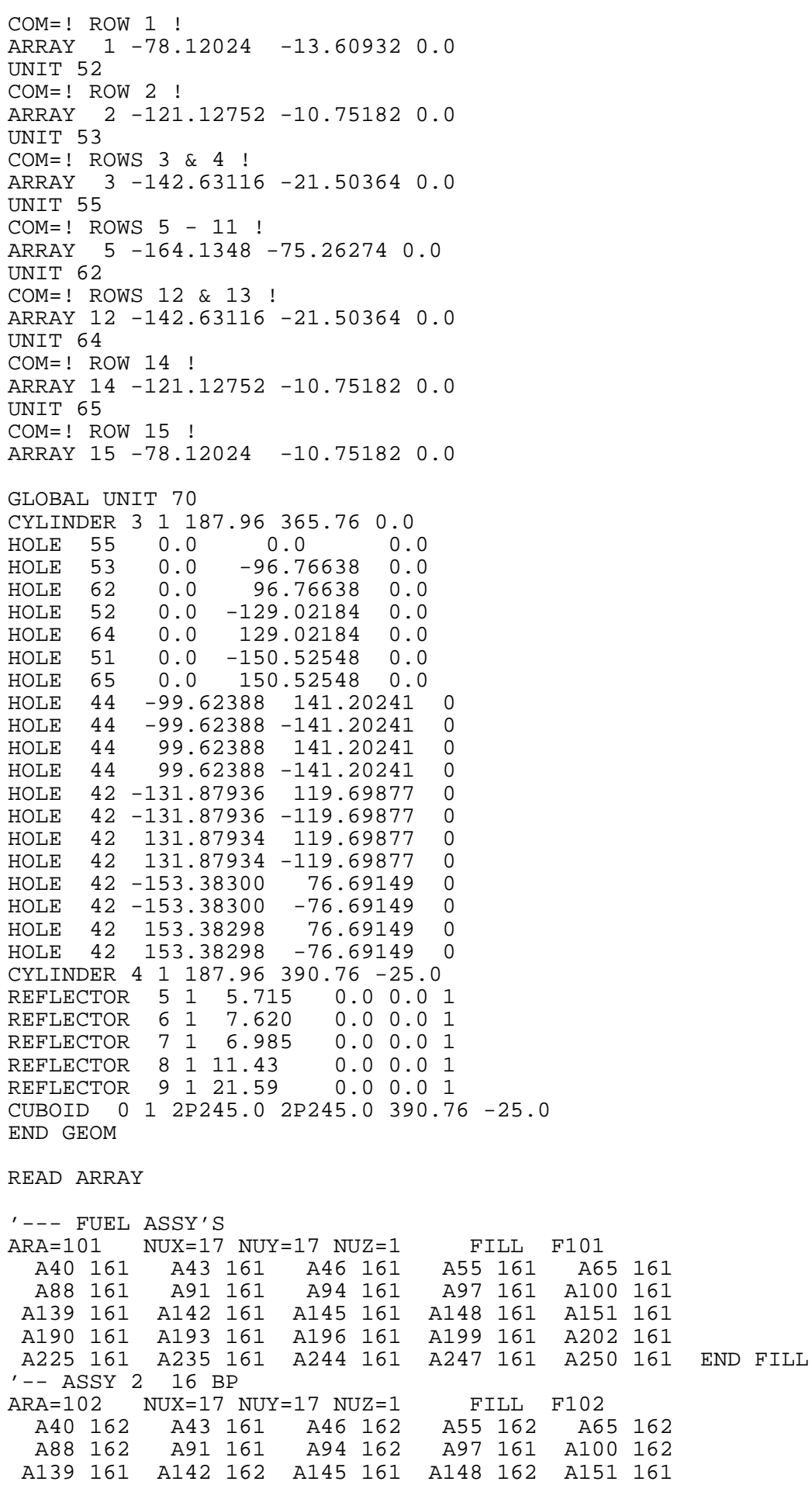


Table D.9 (continued)

\begin{tabular}{|c|c|c|c|c|c|c|c|c|c|}
\hline A190 162 & A193 & 161 & A196 162 & A199 & 161 & A202 & 162 & & \\
\hline A225 162 & A235 & 162 & A244 162 & A2 47 & 161 & A250 & 162 & END & FILL \\
\hline$A R A=103$ & $\mathrm{NUX}=1$ & 7 NUY & $=17 \quad \mathrm{NUZ}=1$ & & ILL & F103 & & & \\
\hline $\mathrm{A} 40 \quad 161$ & A43 & 161 & A46 161 & A55 & 161 & A 65 & 161 & & \\
\hline A88 161 & A91 & 161 & A94 161 & A97 & 161 & A100 & 161 & & \\
\hline A139 161 & A142 & 161 & A145 161 & A148 & 161 & A151 & 161 & & \\
\hline A190 161 & A193 & 161 & $\begin{array}{lll}A 196 & 161\end{array}$ & A199 & 161 & A202 & 161 & & \\
\hline A225 161 & A235 & 161 & A244 161 & A2 47 & 161 & A250 & 161 & END & FILL \\
\hline $1-$ ASSY & 424 & $\mathrm{BP}$ & & & & & & & \\
\hline$A R A=104$ & $\mathrm{NUX}=1$ & 7 NUY & $=17 \mathrm{NUZ}=1$ & & ILL & F104 & & & \\
\hline A $40 \quad 163$ & A43 & 163 & A46 163 & A55 & 163 & A 65 & 163 & & \\
\hline A88 163 & A91 & 163 & A94 163 & A97 & 163 & A1 00 & 163 & & \\
\hline A139 163 & A142 & 163 & A145 161 & A148 & 163 & A151 & 163 & & \\
\hline A190 163 & A193 & 163 & A196 163 & A199 & 163 & A2 02 & 163 & & \\
\hline A225 163 & A235 & 163 & A244 163 & A2 47 & 163 & A250 & 163 & END & FILL \\
\hline$A R A=105$ & $\mathrm{NUX}=1$ & 7 NUY & $=17 \mathrm{NUZ}=1$ & & ILL & F105 & & & \\
\hline A40 161 & A 43 & 161 & A4 $6 \quad 161$ & A 55 & 161 & A 65 & 161 & & \\
\hline A88 161 & A91 & 161 & A94 161 & A97 & 161 & A100 & 161 & & \\
\hline A139 161 & A142 & 161 & A145 161 & A1 48 & 161 & A151 & 161 & & \\
\hline A190 161 & A193 & 161 & A196 161 & A199 & 161 & A202 & 161 & & \\
\hline A225 161 & A2 35 & 161 & A244 161 & A2 47 & 161 & A2 250 & 161 & END & FILL \\
\hline - ASSY & $6 \quad 12$ & & & & & & & & \\
\hline$A R A=106$ & $\mathrm{NUX}=1$ & 7 NUY & $=17 \quad \mathrm{NUZ}=1$ & & ILL & F106 & & & \\
\hline $\mathrm{A} 40 \quad 164$ & A43 & 161 & A46 164 & A55 & 161 & A 65 & 161 & & \\
\hline A88 164 & A91 & 161 & A94 164 & A97 & 161 & A100 & 164 & & \\
\hline A139 161 & A142 & 164 & A145 161 & A148 & 164 & A151 & 161 & & \\
\hline A190 164 & A193 & 161 & A196 164 & A199 & 161 & A202 & 164 & & \\
\hline A225 161 & A235 & 161 & A244 164 & A2 47 & 161 & A250 & 164 & END & FILL \\
\hline $\mathrm{ARA}=107$ & $\mathrm{NUX}=1$ & 7 NUY & $=17 \mathrm{NUZ}=1$ & & ILL & F107 & & & \\
\hline A 40161 & A43 & 161 & A4 $6 \quad 161$ & A 55 & 161 & A 65 & 161 & & \\
\hline A88 161 & A91 & 161 & A94 161 & A97 & 161 & A100 & 161 & & \\
\hline A139 161 & A142 & 161 & $\begin{array}{ll}\text { A145 } & 161\end{array}$ & A1 48 & 161 & A151 & 161 & & \\
\hline A190 161 & A193 & 161 & A196 161 & A199 & 161 & A2 02 & 161 & & \\
\hline A225 161 & A235 & 161 & A244 161 & A2 47 & 161 & A2 50 & 161 & END & FILL \\
\hline$A R A=108$ & $\mathrm{NUX}=1$ & 7 NUY & $=17 \mathrm{NUZ}=1$ & & ILL & F108 & & & \\
\hline A40 161 & A43 & 161 & A46 161 & A55 & 161 & A 65 & 161 & & \\
\hline A88 161 & A91 & 161 & A94 161 & A97 & 161 & A1 00 & 161 & & \\
\hline A139 161 & A142 & 161 & A145 161 & A148 & 161 & A151 & 161 & & \\
\hline A190 161 & A193 & 161 & A196 161 & A199 & 161 & A202 & 161 & & \\
\hline A225 161 & A235 & 161 & A244 161 & A2 47 & 161 & A2 50 & 161 & END & FILL \\
\hline$A R A=109$ & $\mathrm{NUX}=1$ & 7 NUY & $=17 \mathrm{NUZ}=1$ & & ILL & F109 & & & \\
\hline A40 161 & A43 & 161 & A4 $6 \quad 161$ & A 55 & 161 & A 65 & 161 & & \\
\hline A88 161 & A91 & 161 & A94 161 & A97 & 161 & A100 & 161 & & \\
\hline A139 161 & A 142 & 161 & $\begin{array}{ll}\text { A145 } 161\end{array}$ & A1 48 & 161 & A151 & 161 & & \\
\hline A190 161 & A193 & 161 & A196 161 & A199 & 161 & A202 & 161 & & \\
\hline A225 161 & A235 & 161 & A244 161 & A2 47 & 161 & A2 50 & 161 & END & FILL \\
\hline$A R A=110$ & $\mathrm{NUX}=1$ & 7 NUY & $=17 \mathrm{NUZ}=1$ & & ILL & F110 & & & \\
\hline A $40 \quad 161$ & A43 & 161 & A $46 \quad 161$ & A55 & 161 & A65 & 161 & & \\
\hline A88 161 & A91 & 161 & A94 161 & A97 & 161 & A100 & 161 & & \\
\hline A139 161 & A1 42 & 161 & A145 161 & A1 48 & 161 & A151 & 161 & & \\
\hline A190 161 & A193 & 161 & A196 161 & A199 & 161 & A202 & 161 & & \\
\hline A225 161 & A235 & 161 & A244 161 & A2 47 & 161 & A2 50 & 161 & END & FILL \\
\hline$A R A=111$ & $N U X=1$ & 7 NUY & $=17 \quad \mathrm{NUZ}=1$ & & ILL & F111 & & & \\
\hline $\mathrm{A} 40 \quad 161$ & A43 & 161 & A $46 \quad 161$ & A55 & 161 & A 65 & 161 & & \\
\hline A88 161 & A91 & 161 & A94 161 & A97 & 161 & A100 & 161 & & \\
\hline A139 161 & A142 & 161 & $\begin{array}{ll}\text { A14 } & 161\end{array}$ & A1 48 & 161 & A151 & 161 & & \\
\hline A190 161 & A193 & 161 & A196 161 & A199 & 161 & A202 & 161 & & \\
\hline A225 161 & A235 & 161 & A244 161 & A2 47 & 161 & A2 50 & 161 & END & FILL \\
\hline $\mathrm{ARA}=112$ & $\mathrm{NUX}=1$ & 7 NUY & $=17 \mathrm{NUZ}=1$ & & ILL & F112 & & & \\
\hline $\mathrm{A} 40 \quad 161$ & A43 & 161 & A4 6161 & A 55 & 161 & A 65 & 161 & & \\
\hline A88 161 & A91 & 161 & A94 161 & A97 & 161 & A100 & 161 & & \\
\hline A139 161 & A142 & 161 & A145 161 & A1 48 & 161 & A151 & 161 & & \\
\hline A190 161 & A193 & 161 & A196 161 & A199 & 161 & A2 02 & 161 & & \\
\hline A225 161 & A235 & 161 & A244 161 & A2 47 & 161 & A2 250 & 161 & END & FILL \\
\hline$A R A=113$ & $\mathrm{NUX}=1$ & 7 NUY & $=17 \mathrm{NUZ}=1$ & & ILL & F113 & & & \\
\hline
\end{tabular}


137

Table D.9 (continued)

\begin{tabular}{|c|c|c|c|c|c|c|c|c|c|c|c|}
\hline 140 & 161 & A4 3 & 161 & A4 6 & 161 & A55 & 161 & A65 & 161 & & \\
\hline A88 & 161 & A91 & 161 & A94 & 161 & A97 & 161 & A100 & 161 & & \\
\hline A139 & 161 & A142 & 161 & A145 & 161 & A148 & 161 & A151 & 161 & & \\
\hline A190 & 161 & A193 & 161 & A196 & 161 & A199 & 161 & A2 02 & 161 & & \\
\hline A225 & 161 & A235 & 161 & A2 44 & 161 & A2 47 & 161 & A250 & 161 & END & FILL \\
\hline \multicolumn{12}{|c|}{$\prime--$ ASSY $14 \quad 16$ BP } \\
\hline $\mathrm{ARA}=11$ & & $\mathrm{NUX}=1$ & 7 NUY & $=17 \mathrm{~N}$ & $\mathrm{IUZ}=1$ & & ILL & F114 & & & \\
\hline A4 0 & 165 & A 43 & 161 & A4 6 & 165 & A55 & 165 & A 65 & 165 & & \\
\hline A88 & 165 & A91 & 161 & A94 & 165 & A97 & 161 & A100 & 165 & & \\
\hline A139 & 161 & A142 & 165 & A145 & 161 & A148 & 165 & A151 & 161 & & \\
\hline A190 & 165 & A193 & 161 & A196 & 165 & A199 & 161 & A202 & 165 & & \\
\hline A225 & 165 & A235 & 165 & A2 44 & 165 & A2 47 & 161 & A250 & 165 & END & FILL \\
\hline$A R A=11$ & & $N U X=1$ & 7 NUY & $=17 \mathrm{~N}$ & $\mathrm{IUZ}=1$ & & ILL & F115 & & & \\
\hline A 40 & 161 & A4 3 & 161 & A4 6 & 161 & A55 & 161 & A65 & 161 & & \\
\hline A8 8 & 161 & A91 & 161 & A94 & 161 & A97 & 161 & A100 & 161 & & \\
\hline A139 & 161 & A142 & 161 & A145 & 161 & A148 & 161 & A151 & 161 & & \\
\hline A190 & 161 & A193 & 161 & A196 & 161 & A199 & 161 & A202 & 161 & & \\
\hline A225 & 161 & A235 & 161 & A2 44 & 161 & A2 47 & 161 & A250 & 161 & END & FILL \\
\hline \multicolumn{2}{|c|}{$A R A=116$} & $N U X=1$ & 7 NUY & $=17 \mathrm{~N}$ & $\mathrm{UUZ}=1$ & & ILL & F116 & & & \\
\hline A 40 & 161 & A4 3 & 161 & A4 6 & 161 & A55 & 161 & A65 & 161 & & \\
\hline A88 & 161 & A91 & 161 & A94 & 161 & A97 & 161 & A100 & 161 & & \\
\hline A139 & 161 & A1 42 & 161 & A1 45 & 161 & A148 & 161 & A151 & 161 & & \\
\hline A190 & 161 & A193 & 161 & A196 & 161 & A199 & 161 & A202 & 161 & & \\
\hline A225 & 161 & A235 & 161 & A2 44 & 161 & A2 47 & 161 & A250 & 161 & END & FILL \\
\hline \multicolumn{12}{|c|}{ - ASSY $17 \quad 12 \mathrm{BP}$} \\
\hline \multicolumn{2}{|c|}{$\mathrm{ARA}=117$} & \multicolumn{4}{|c|}{$\mathrm{NUX}=17 \quad \mathrm{NUY}=17 \quad \mathrm{NUZ}=1$} & \multicolumn{2}{|c|}{ FILL } & \multicolumn{2}{|l|}{ F117 } & & \\
\hline A40 & 166 & A4 3 & 161 & A4 6 & 166 & A55 & 161 & A65 & 161 & & \\
\hline A88 & 166 & A91 & 161 & A94 & 166 & A97 & 161 & A100 & 166 & & \\
\hline A139 & 161 & A142 & 166 & A145 & 161 & A148 & 166 & A151 & 161 & & \\
\hline A190 & 166 & A193 & 161 & A196 & 166 & A199 & 161 & A202 & 166 & & \\
\hline A225 & 161 & A235 & 161 & A2 44 & 166 & A2 47 & 161 & A250 & 166 & END & FILL \\
\hline $\mathrm{ARA}=11$ & & $\mathrm{NUX}=1$ & 7 NUY & $=17 \mathrm{~N}$ & $\mathrm{IUZ}=1$ & & ILL & F118 & & & \\
\hline A 40 & 161 & A 43 & 161 & A4 6 & 161 & A55 & 161 & A65 & 161 & & \\
\hline A88 & 161 & A91 & 161 & A94 & 161 & A97 & 161 & A100 & 161 & & \\
\hline A139 & 161 & A142 & 161 & A145 & 161 & A148 & 161 & A151 & 161 & & \\
\hline A190 & 161 & A193 & 161 & A196 & 161 & A199 & 161 & A202 & 161 & & \\
\hline A225 & 161 & A235 & 161 & A2 44 & 161 & A2 47 & 161 & A250 & 161 & END & FILL \\
\hline \multicolumn{12}{|c|}{ '-- ASSY $19 \quad 20$ BP } \\
\hline \multicolumn{2}{|c|}{$\mathrm{ARA}=119$} & \multicolumn{4}{|c|}{$\mathrm{NUX}=17 \quad \mathrm{NUY}=17 \quad \mathrm{NUZ}=1$} & \multicolumn{2}{|c|}{ FILL } & F119 & & & \\
\hline A 40 & 167 & A 43 & 167 & A4 6 & 167 & A55 & 167 & A 65 & 167 & & \\
\hline A88 & 167 & A91 & 161 & A94 & 167 & A97 & 161 & A100 & 167 & & \\
\hline A139 & 167 & A142 & 167 & A145 & 161 & A148 & 167 & A151 & 167 & & \\
\hline A190 & 167 & A193 & 161 & A196 & 167 & A199 & 161 & A202 & 167 & & \\
\hline A225 & 167 & A235 & 167 & A2 44 & 167 & A2 47 & 167 & A2 50 & 167 & END & FILL \\
\hline $\mathrm{ARA}=12$ & & $\mathrm{NUX}=1$ & 7 NUY & $=17 \mathrm{~N}$ & $\mathrm{IUZ}=1$ & & ILL & F120 & & & \\
\hline A4 0 & 161 & A4 3 & 161 & A4 6 & 161 & A55 & 161 & A 65 & 161 & & \\
\hline A88 & 161 & A91 & 161 & A94 & 161 & A97 & 161 & A100 & 161 & & \\
\hline A139 & 161 & A1 42 & 161 & A145 & 161 & A148 & 161 & A151 & 161 & & \\
\hline A190 & 161 & A193 & 161 & A196 & 161 & A199 & 161 & A202 & 161 & & \\
\hline A225 & 161 & A235 & 161 & A2 44 & 161 & A2 47 & 161 & A250 & 161 & END & FILL \\
\hline $\mathrm{ARA}=12$ & & $\mathrm{NUX}=1$ & 7 NUY & $=17 \mathrm{~N}$ & $\mathrm{IUZ}=1$ & & ILL & F121 & & & \\
\hline A 40 & 161 & A4 3 & 161 & A4 6 & 161 & A55 & 161 & A 65 & 161 & & \\
\hline A88 & 161 & A91 & 161 & A94 & 161 & A97 & 161 & A100 & 161 & & \\
\hline A139 & 161 & A142 & 161 & A145 & 161 & A148 & 161 & A151 & 161 & & \\
\hline A190 & 161 & A193 & 161 & A196 & 161 & A199 & 161 & A202 & 161 & & \\
\hline A225 & 161 & A235 & 161 & A2 44 & 161 & A2 47 & 161 & A2 50 & 161 & END & FILL \\
\hline $\mathrm{ARA}=12$ & & $\mathrm{NUX}=1$ & 7 NUY & $=17 \mathrm{~N}$ & $\mathrm{IUZ}=1$ & & ILL & F122 & & & \\
\hline A 40 & 161 & A4 3 & 161 & A4 6 & 161 & A55 & 161 & A65 & 161 & & \\
\hline A88 & 161 & A91 & 161 & A94 & 161 & A97 & 161 & A100 & 161 & & \\
\hline A139 & 161 & A142 & 161 & A145 & 161 & A148 & 161 & A151 & 161 & & \\
\hline A190 & 161 & A193 & 161 & A196 & 161 & A199 & 161 & A202 & 161 & & \\
\hline A225 & 161 & A235 & 161 & A2 44 & 161 & A2 47 & 161 & A250 & 161 & END & FILL \\
\hline $\mathrm{ARA}=12$ & & $\mathrm{NUX}=1$ & 7 NUY & $=17 \mathrm{~N}$ & $\mathrm{IUZ}=1$ & & ILL & F123 & & & \\
\hline A 40 & 161 & A 43 & 161 & A4 6 & 161 & A55 & 161 & A 65 & 161 & & \\
\hline
\end{tabular}


138

Table D.9 (continued)

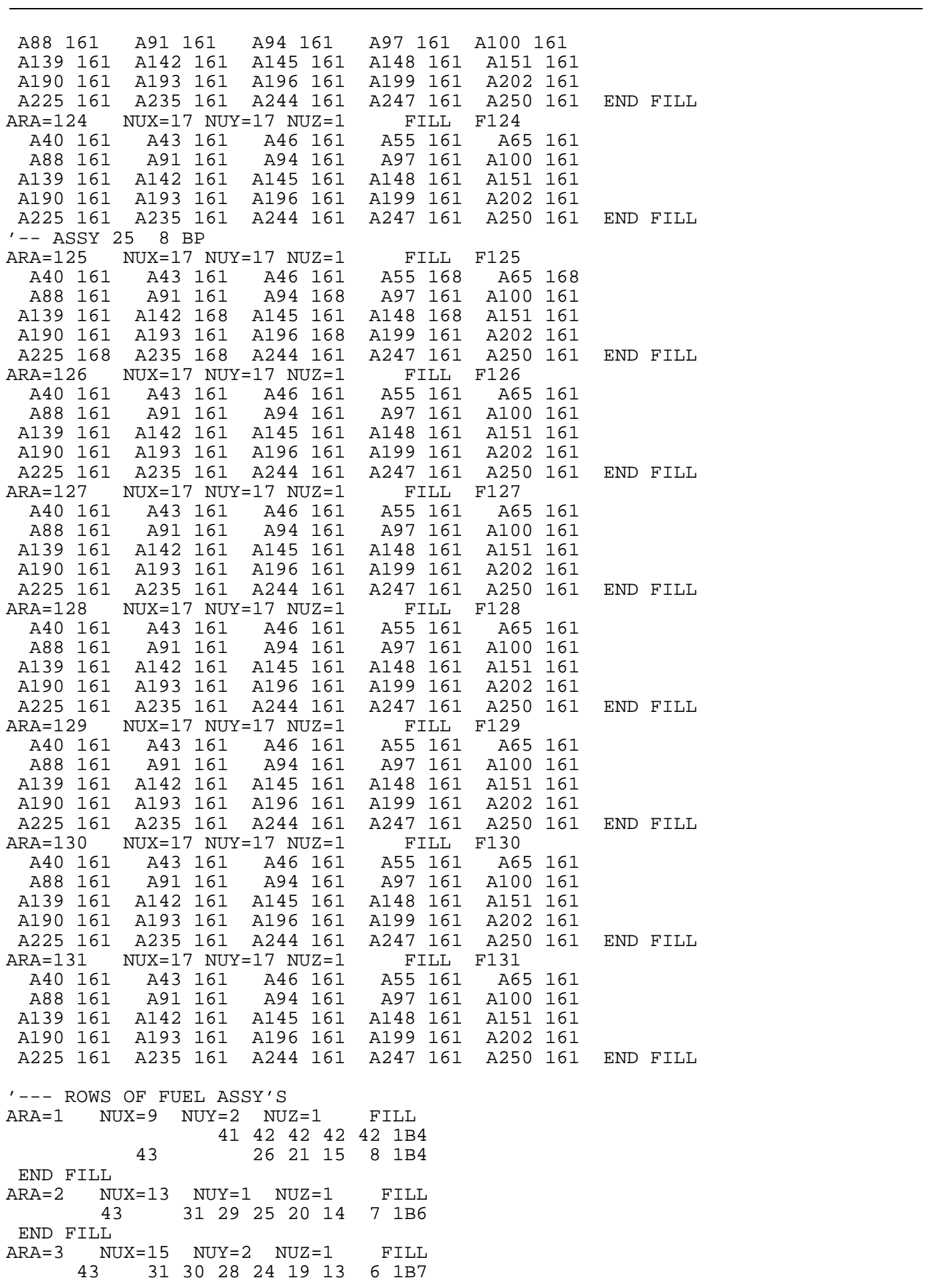




\section{Table D.9 (continued)}

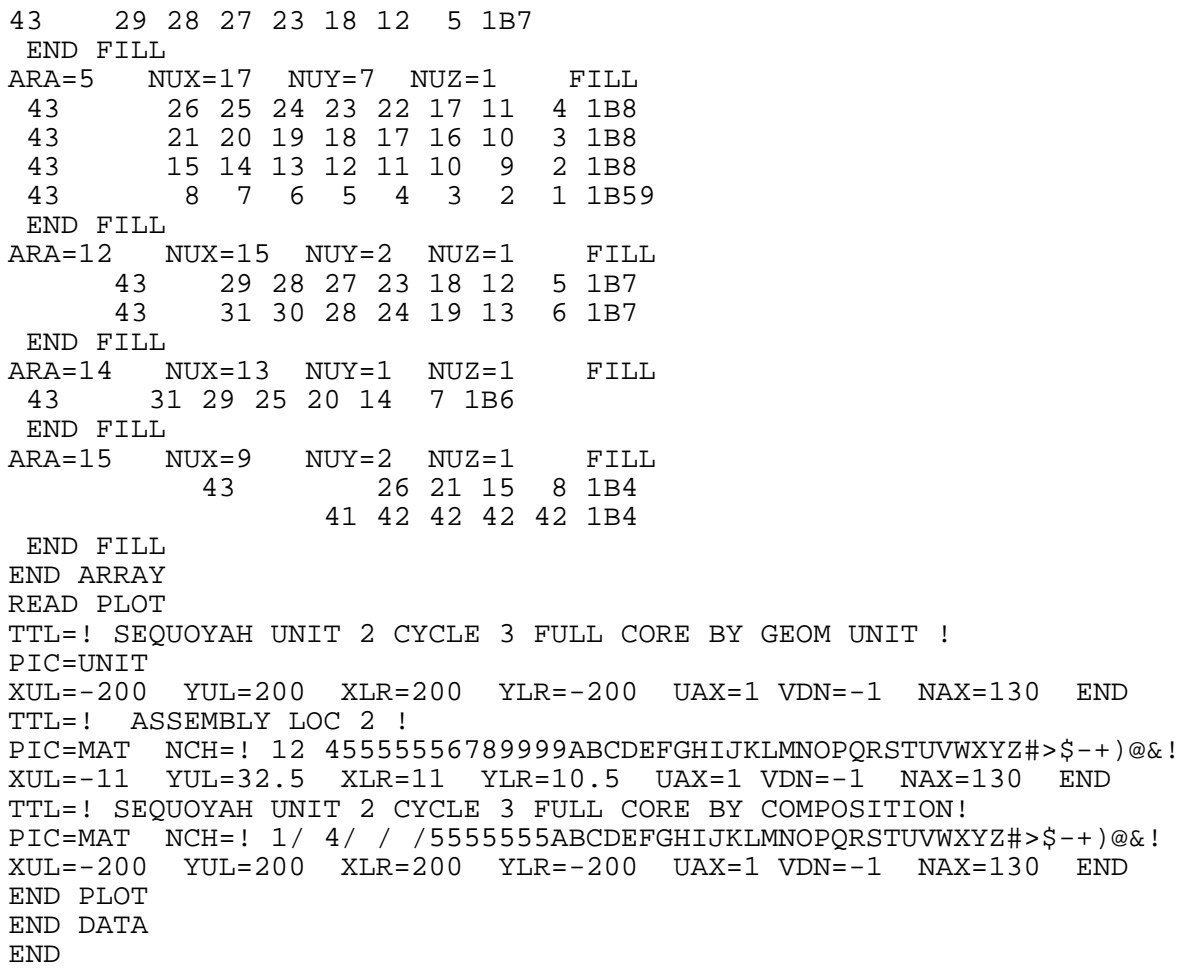


Table D.10. KENO V.a input file for BOC, HFP

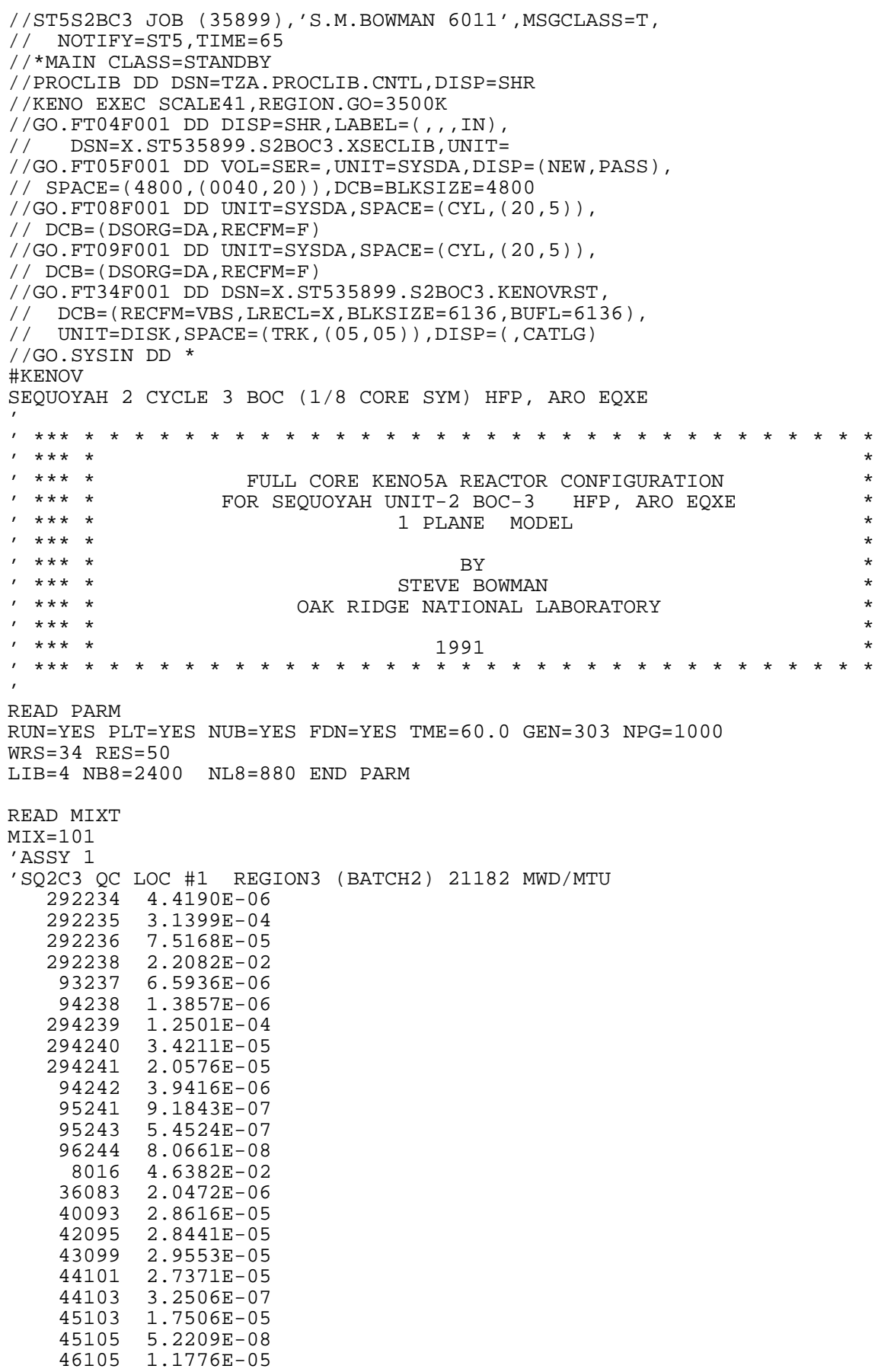


141

Table D.10 (continued)

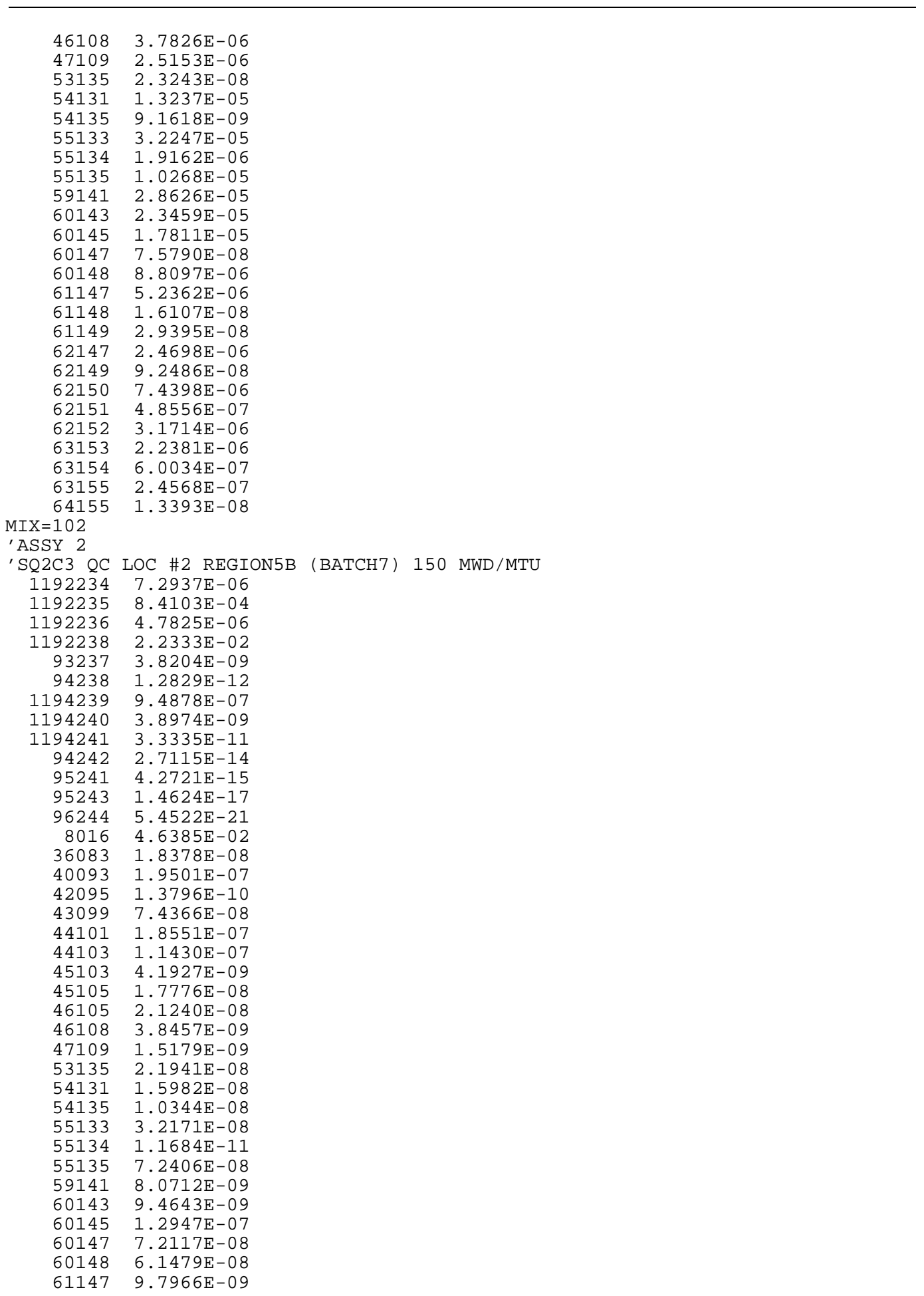


142

Table D.10 (continued)

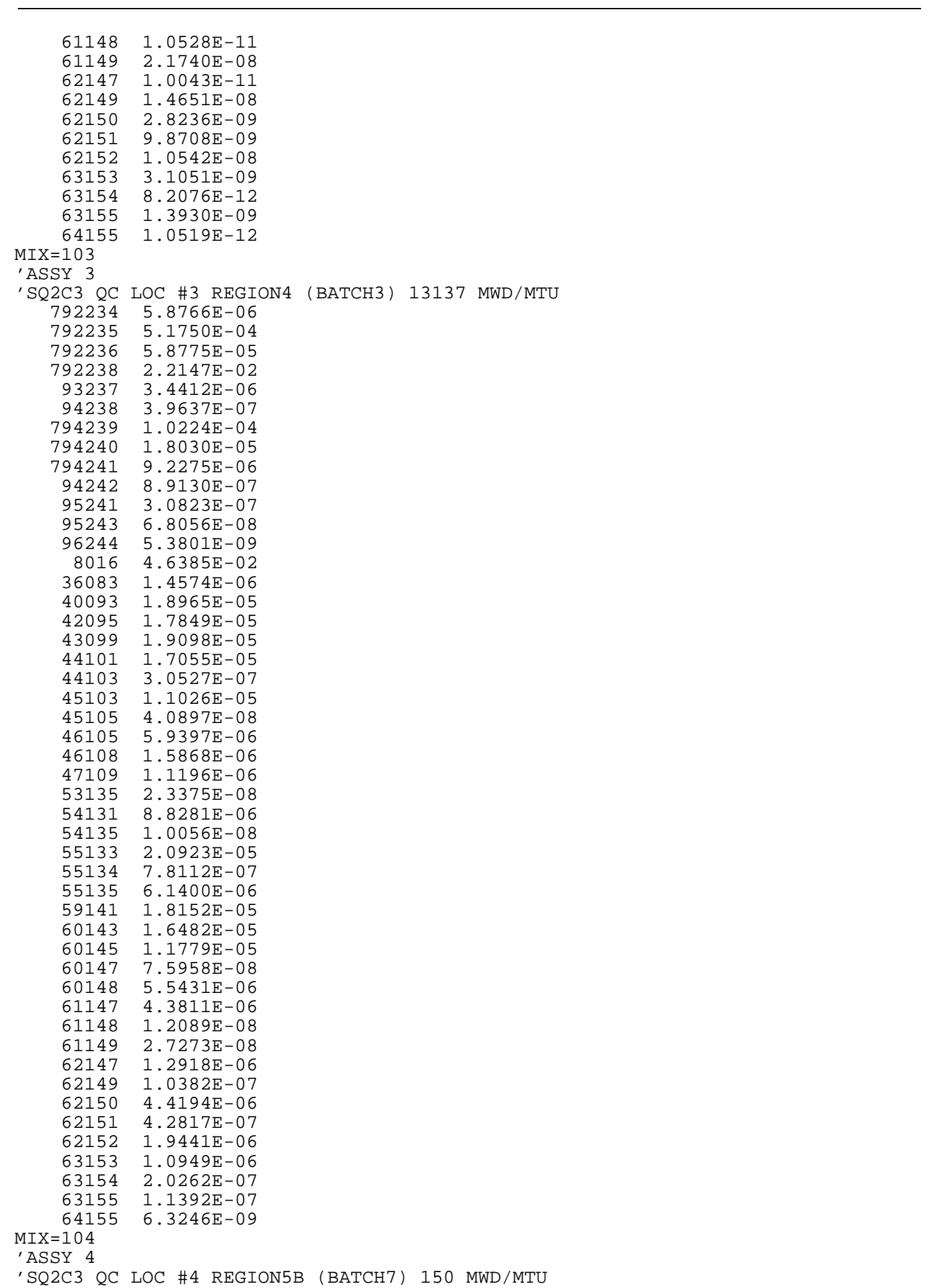


143

Table D.10 (continued)

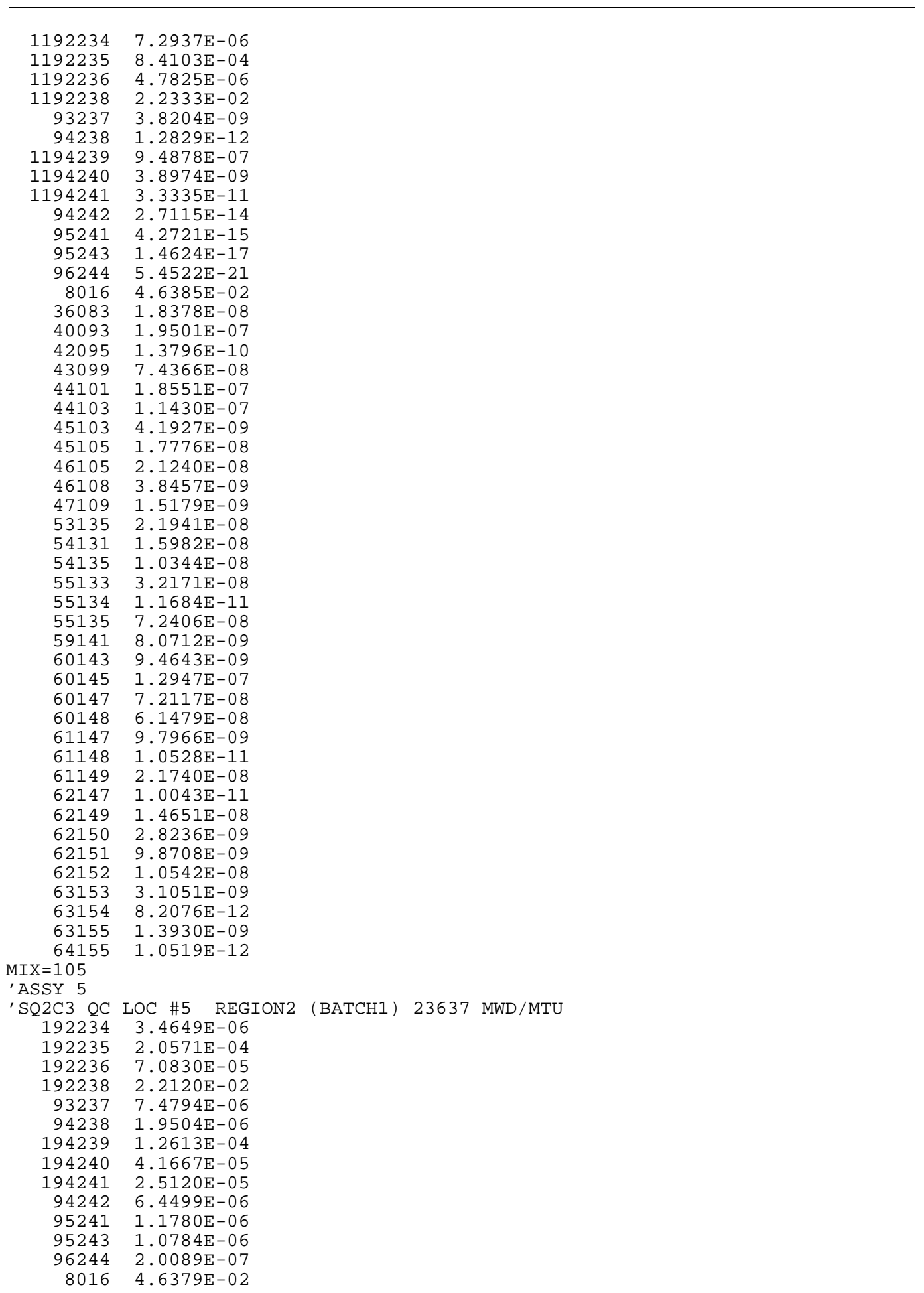


144

Table D.10 (continued)

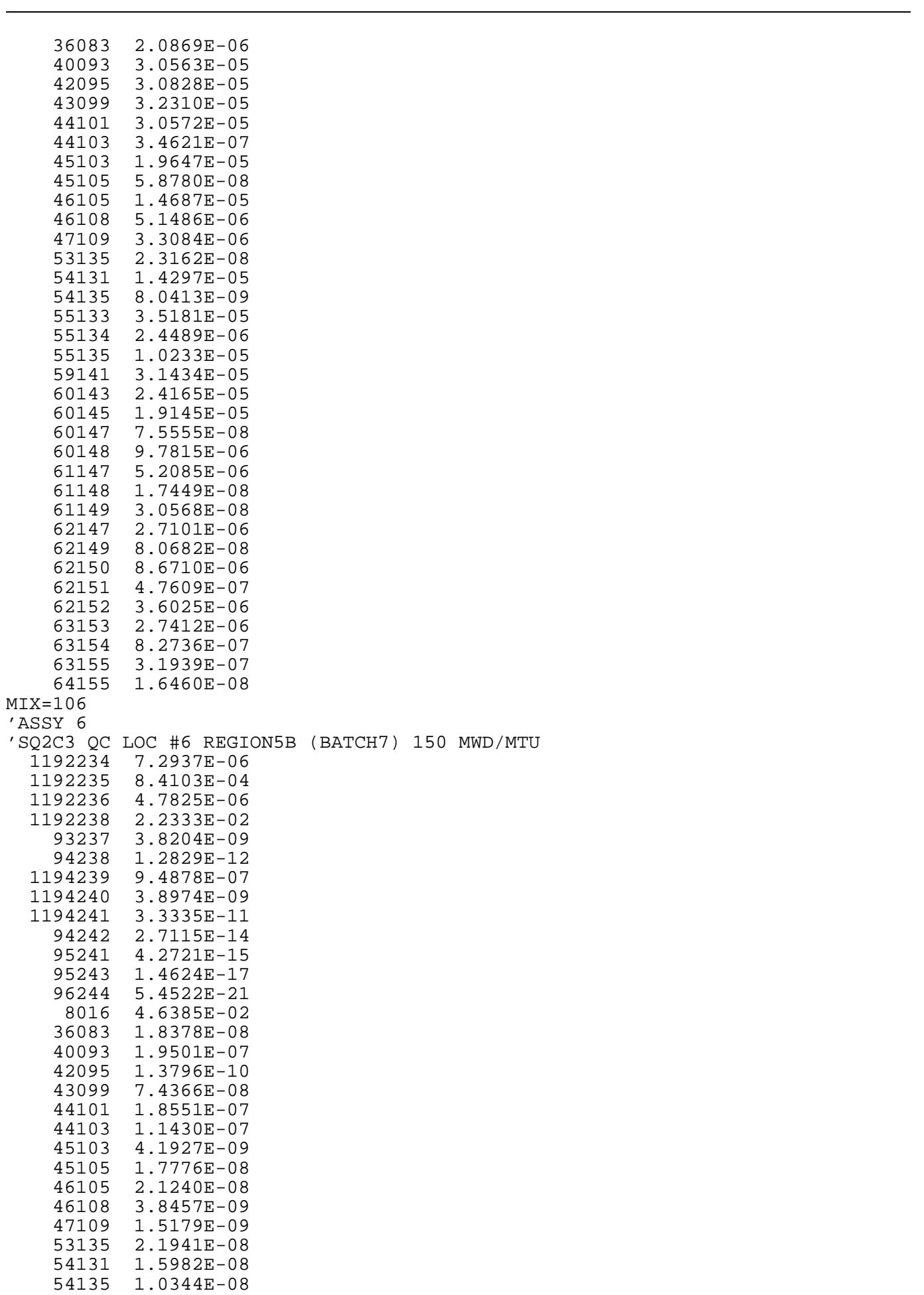


145

Table D.10. (continued)

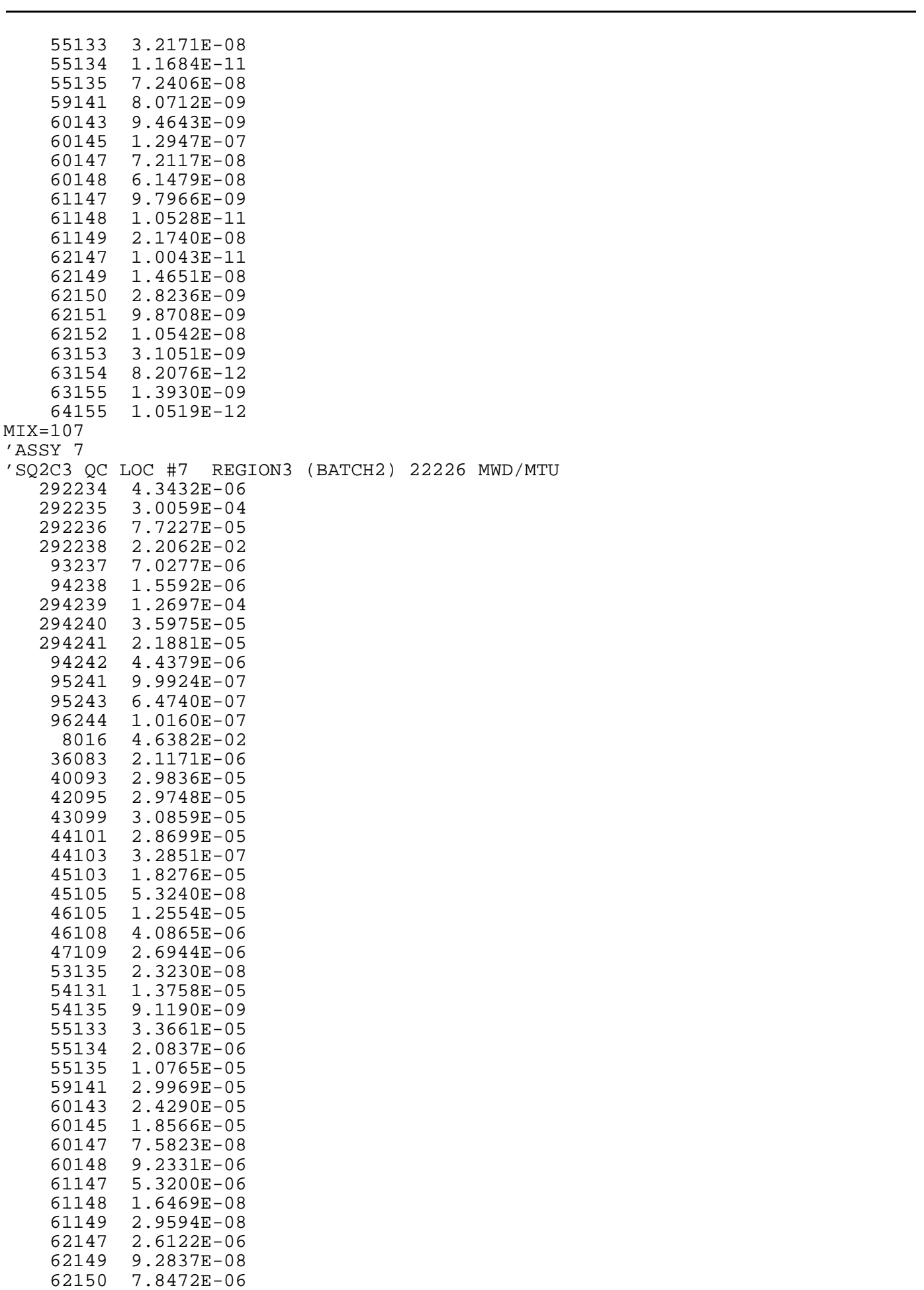


146

Table D.10 (continued)

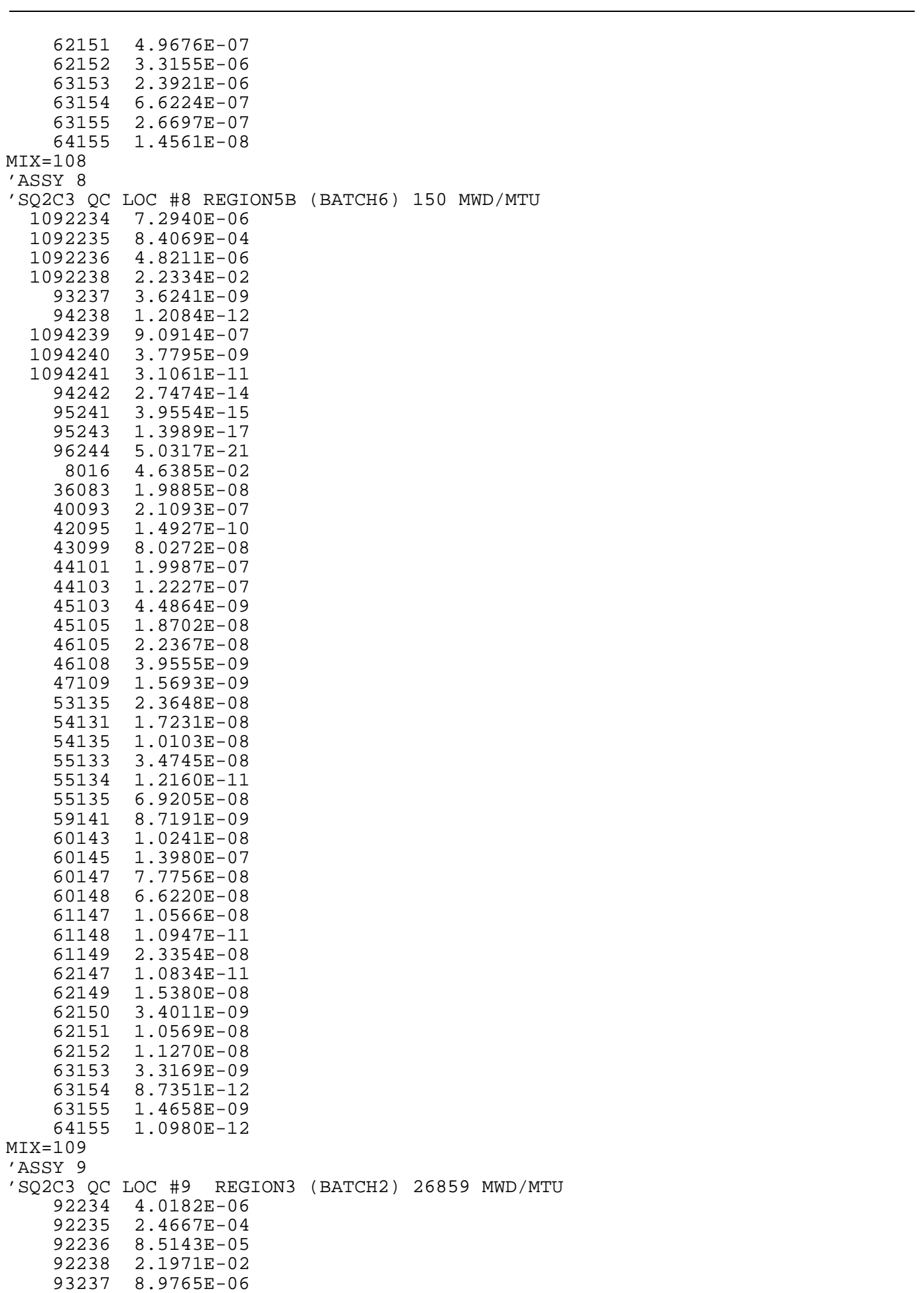


147

Table D.10 (continued)

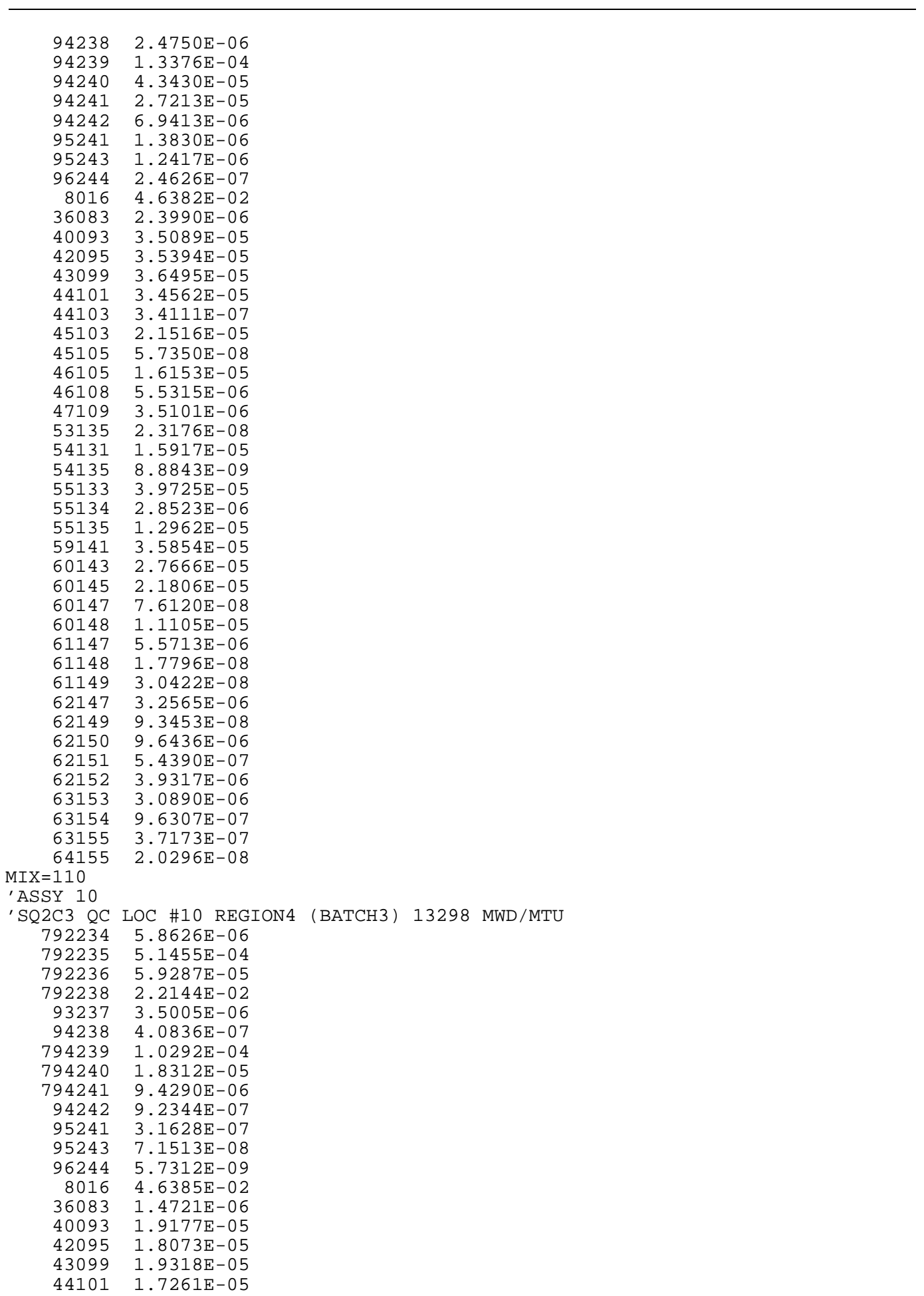


148

Table D.10 (continued)

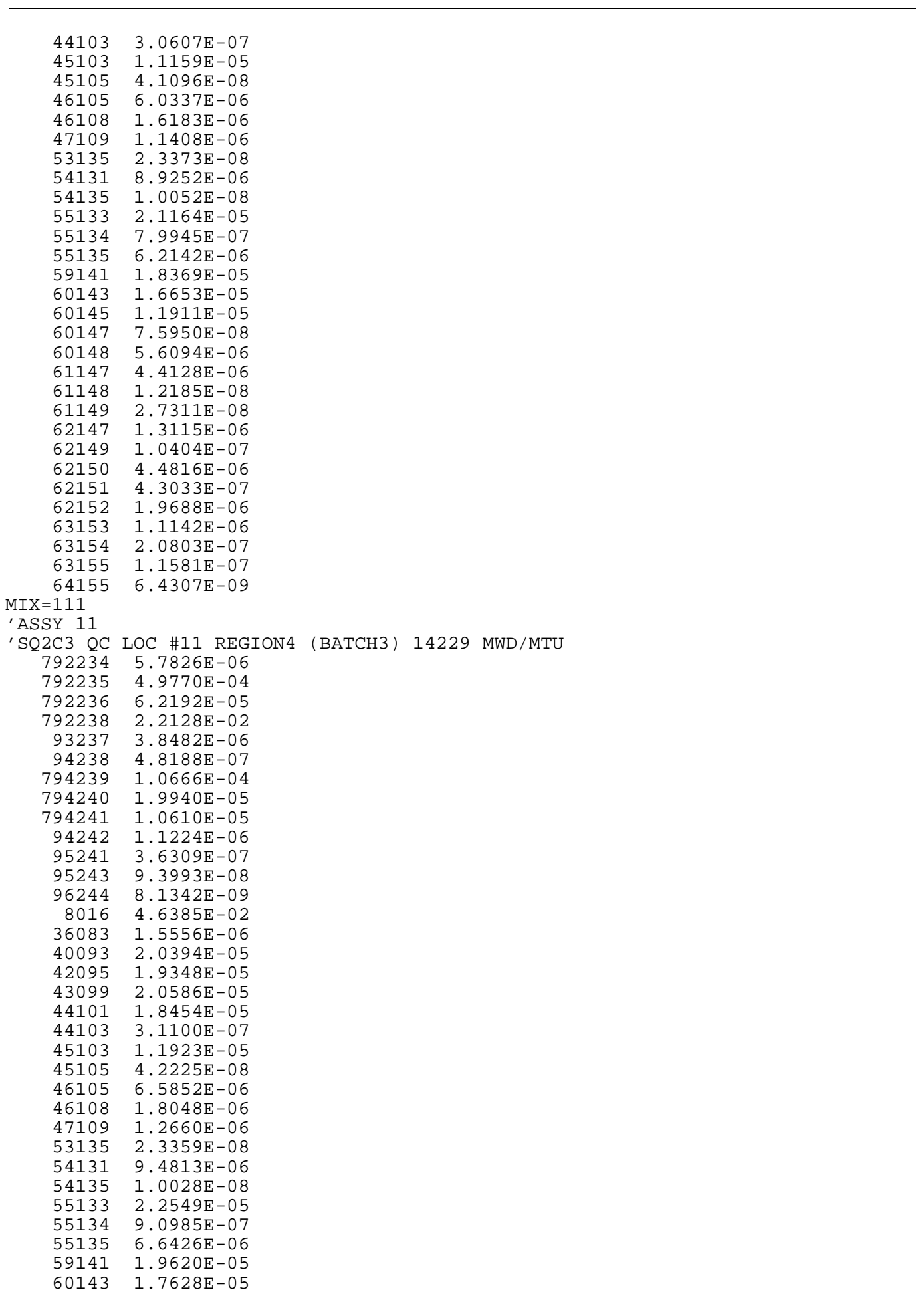


149

Table D.10 (continued)

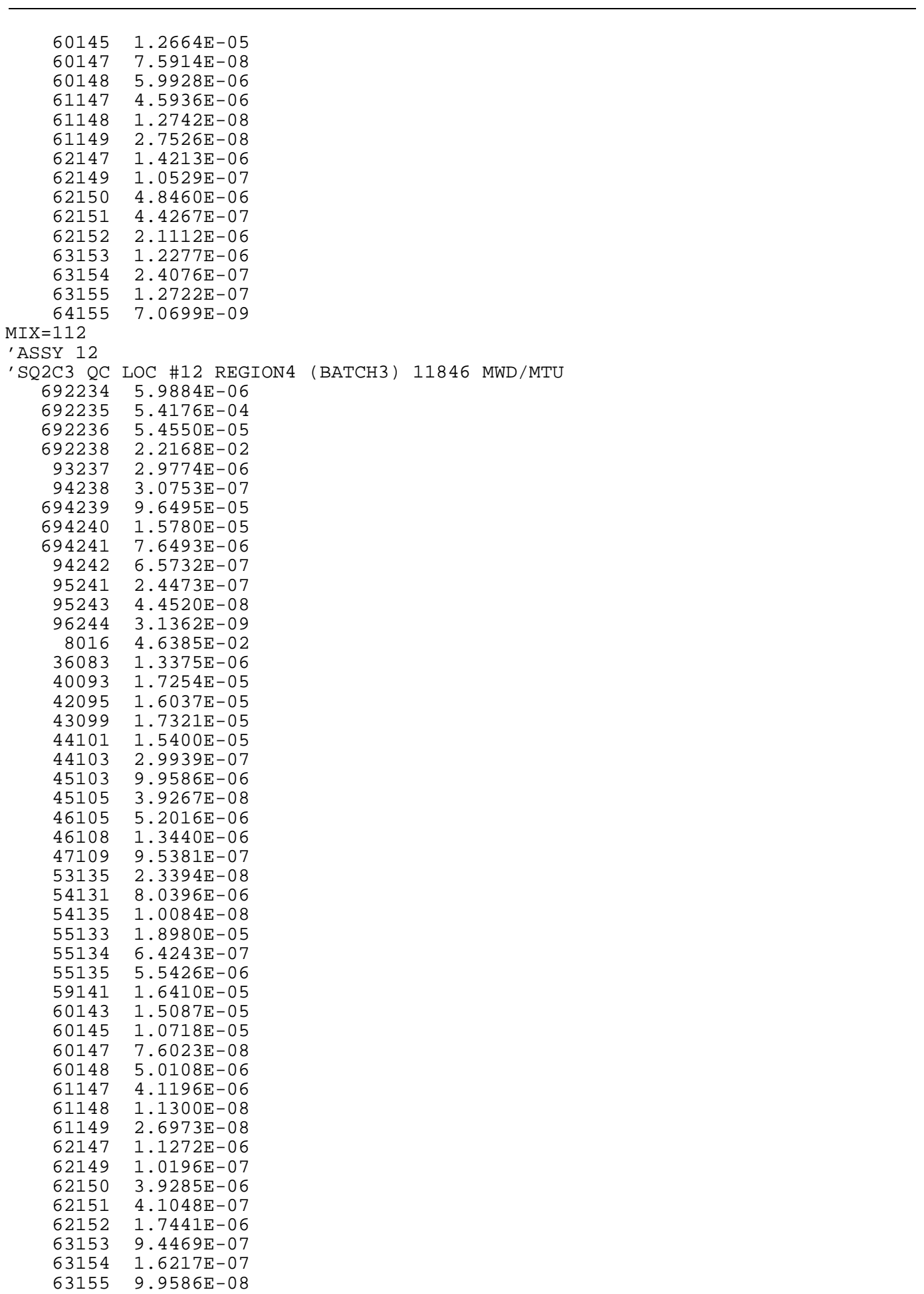


150

Table D.10 (continued)

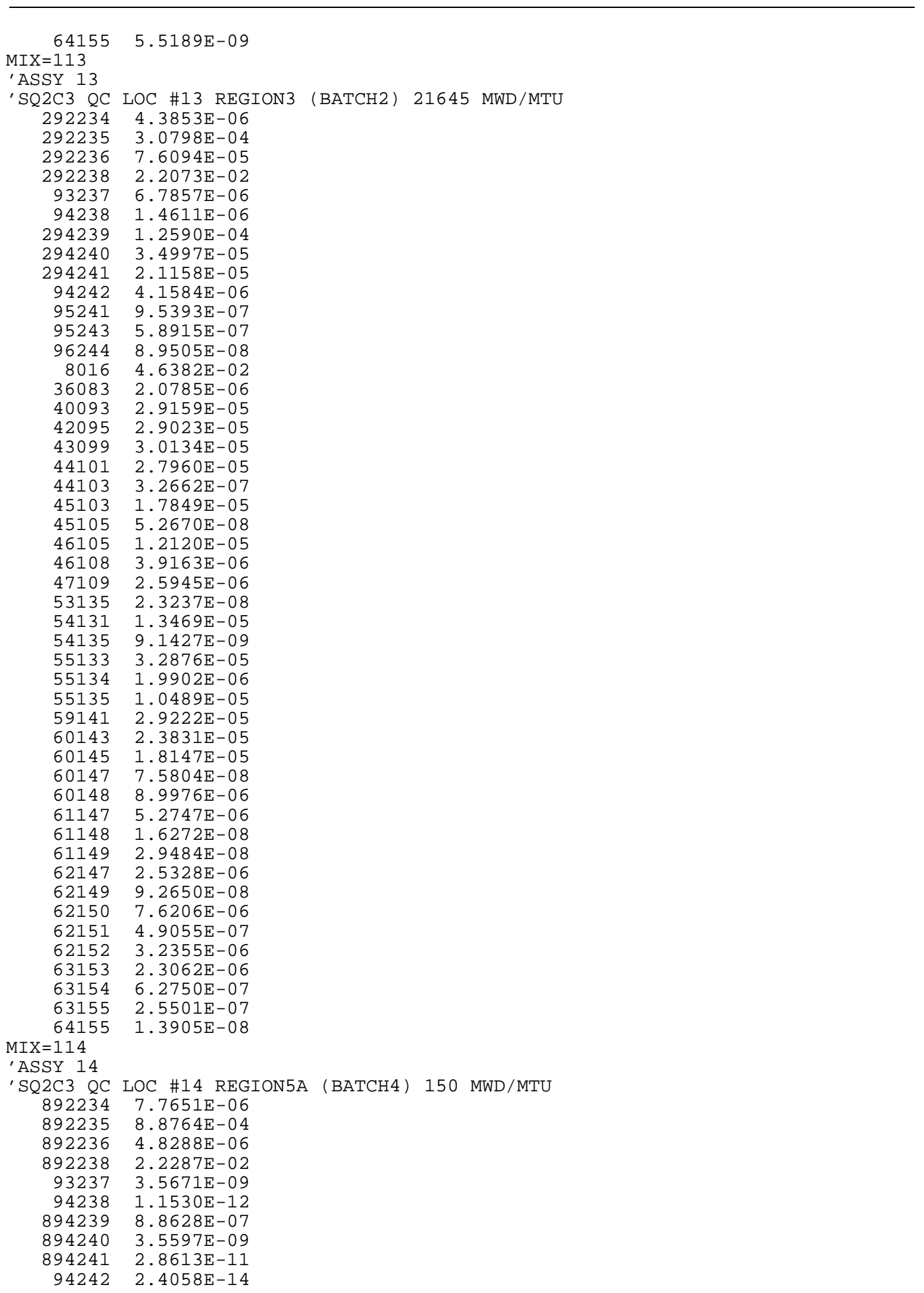


151

Table D.10 (continued)

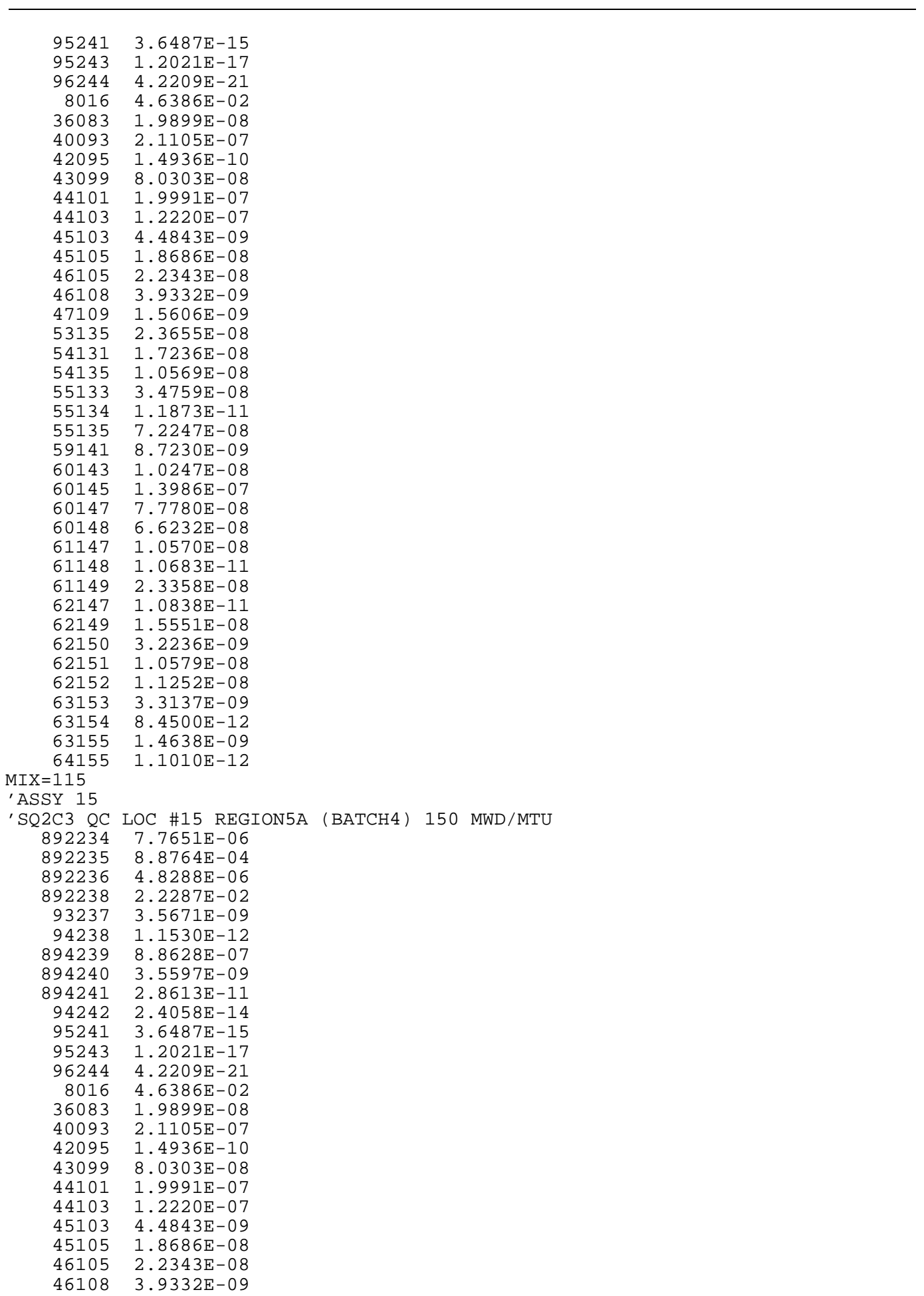


152

Table D.10 (continued)

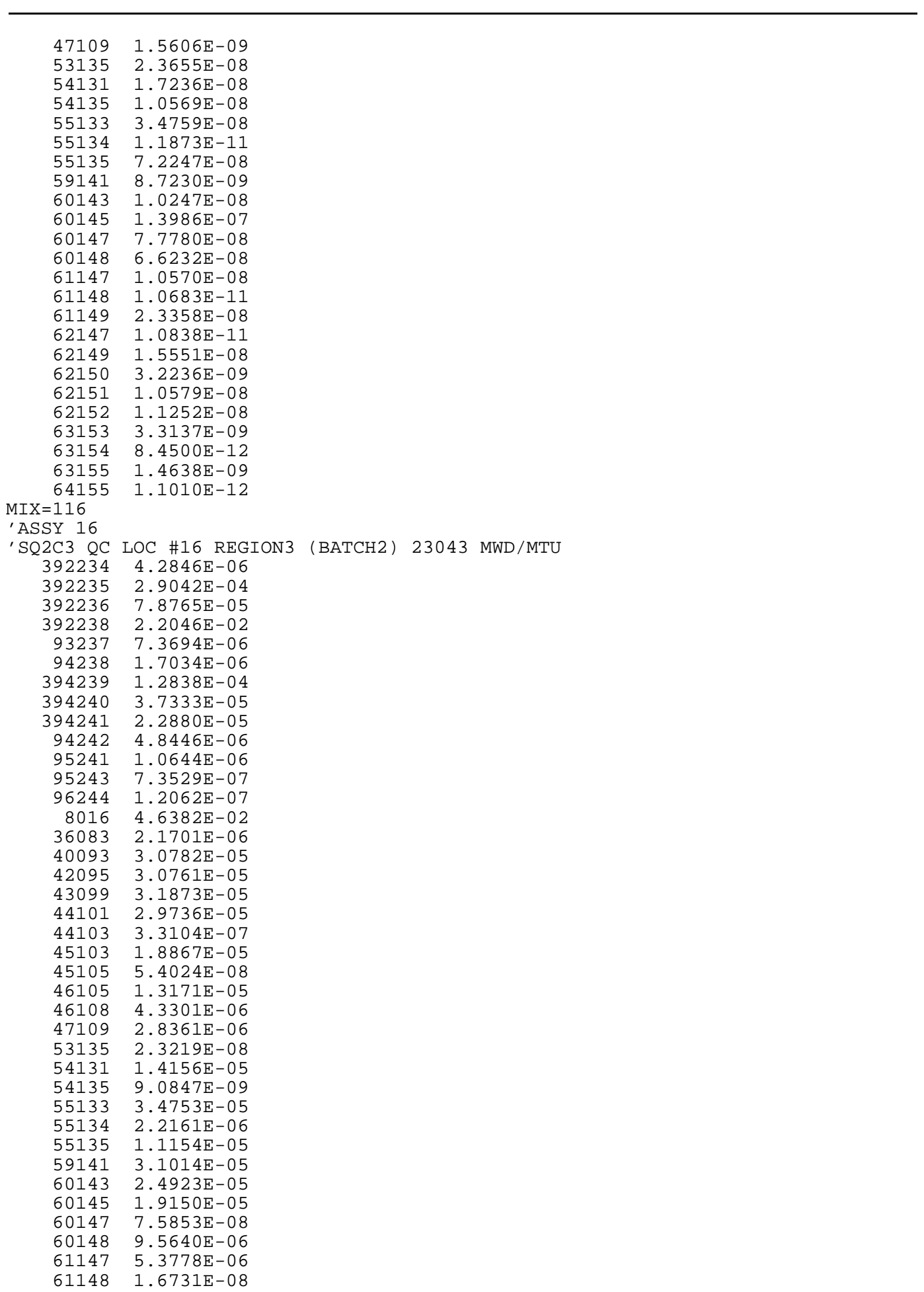


153

Table D.10 (continued)

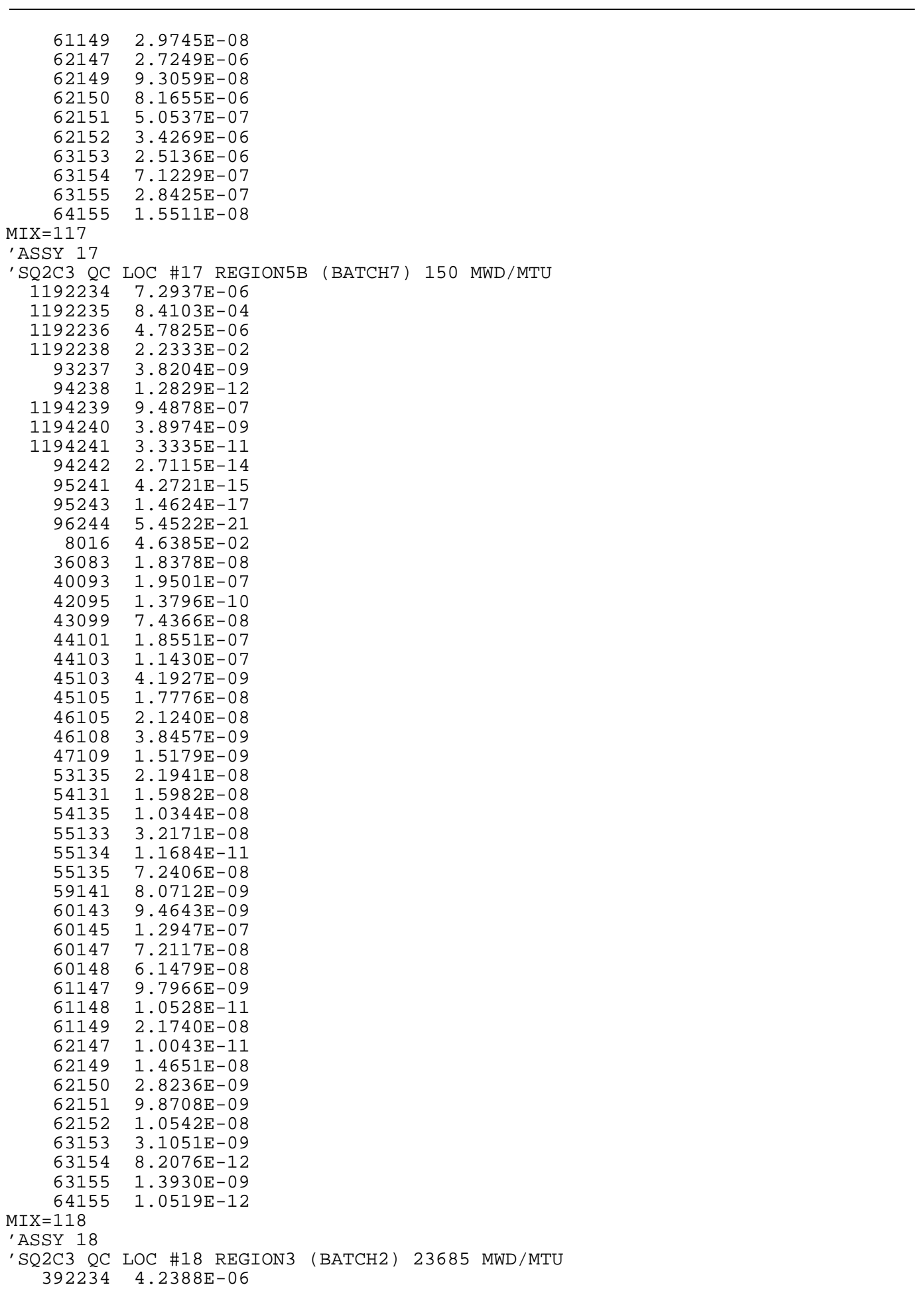


154

Table D.10 (continued)

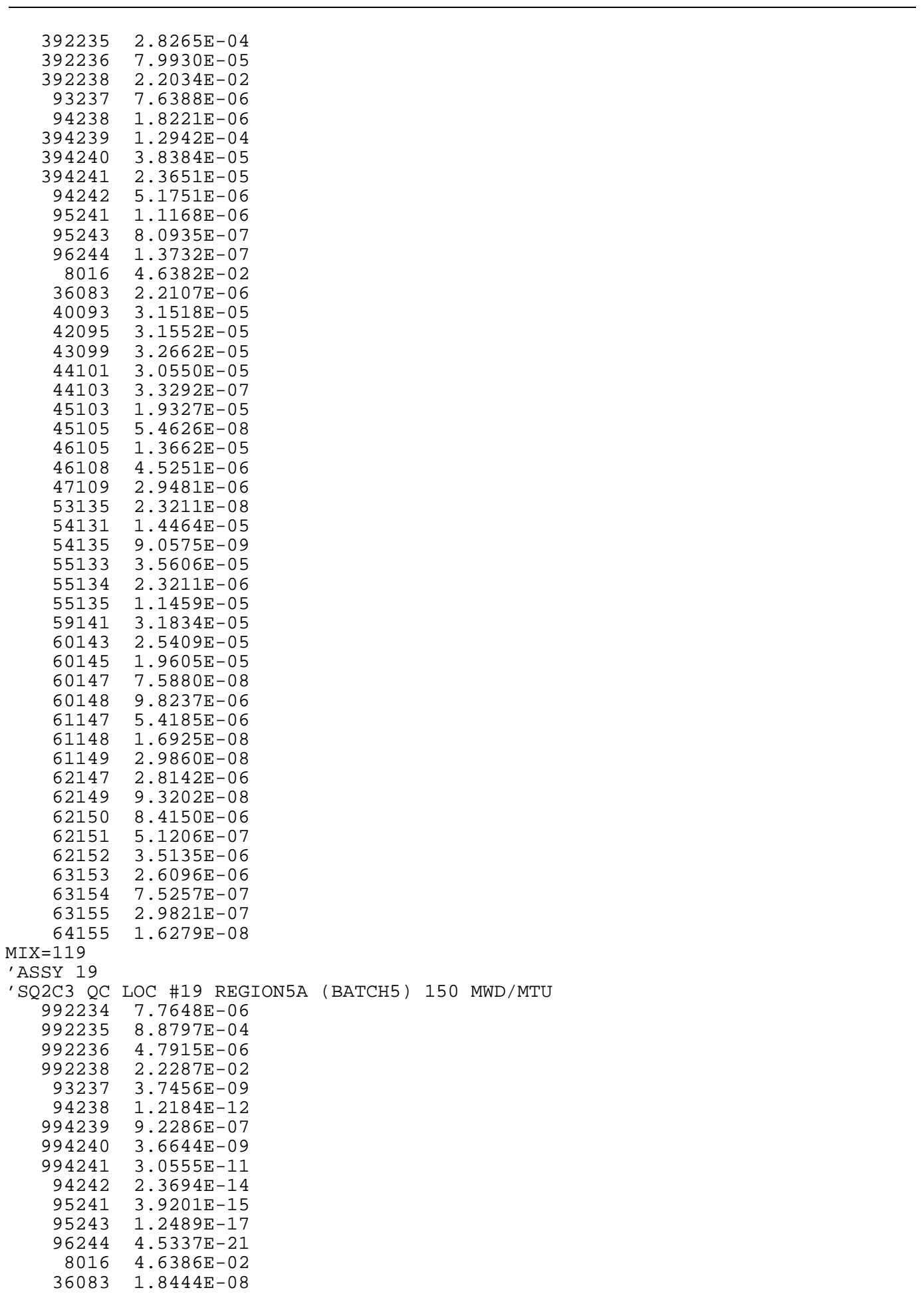


155

Table D.10 (continued)

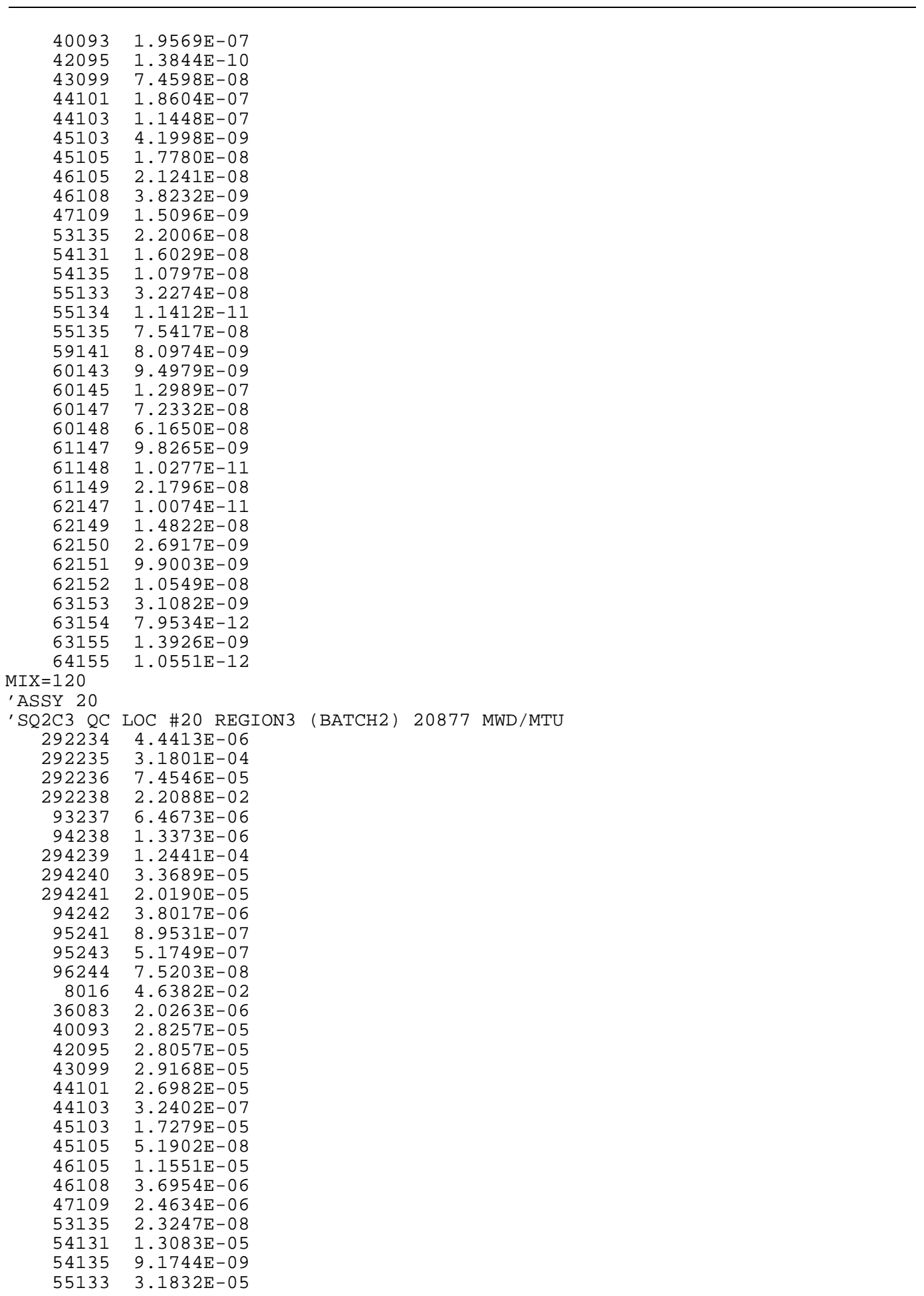


156

Table D.10 (continued)

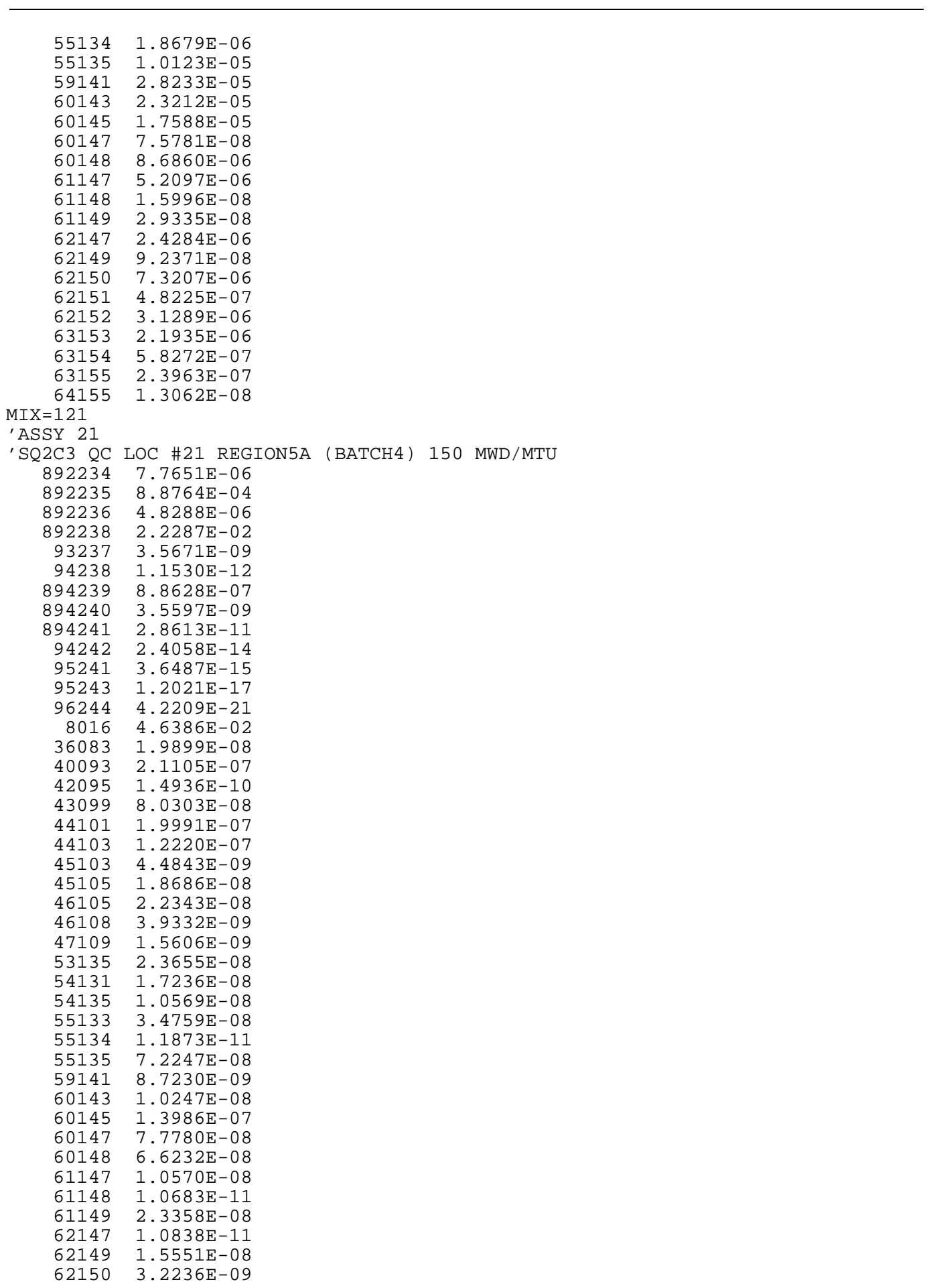


157

Table D.10 (continued)

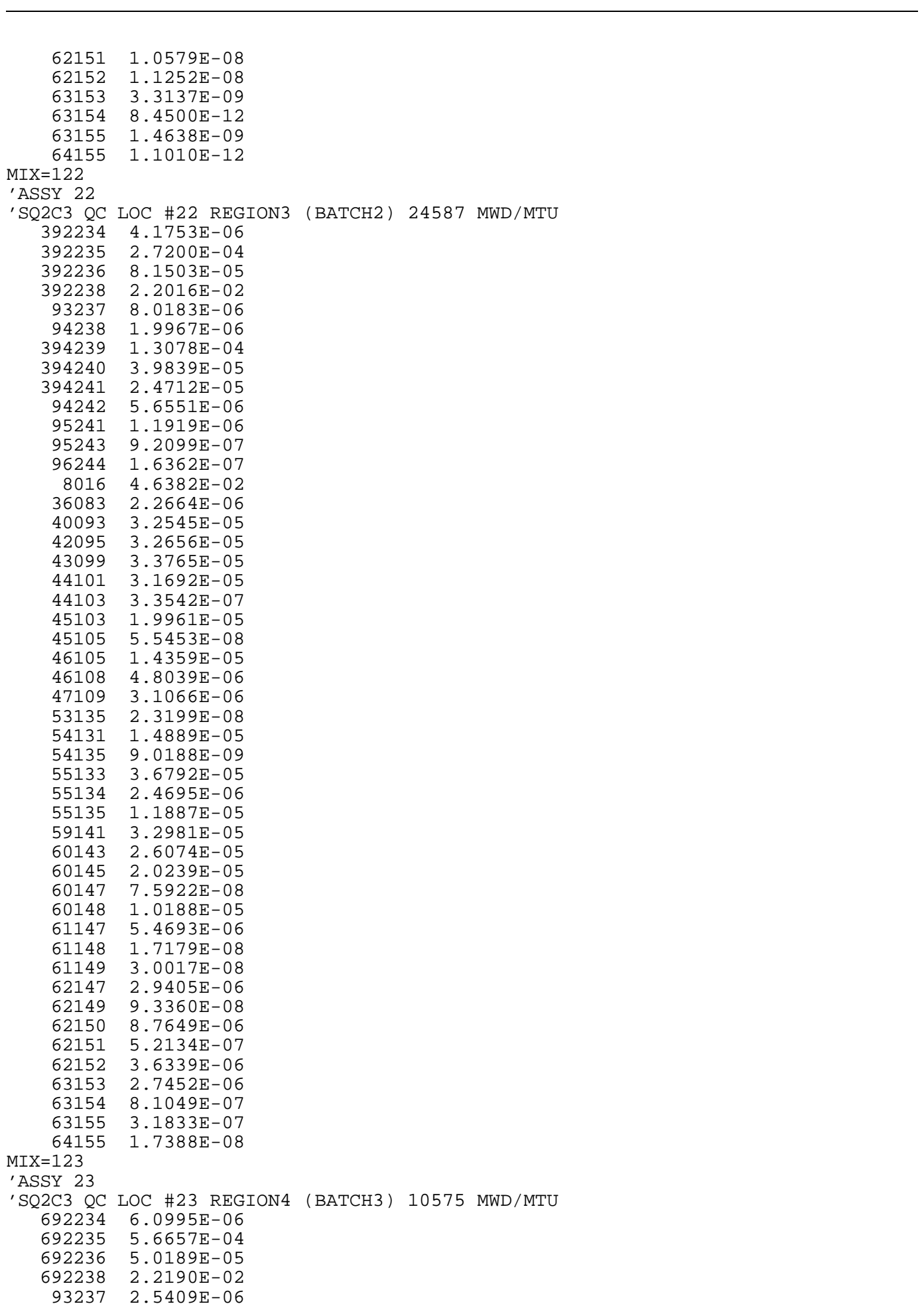


158

Table D.10 (continued)

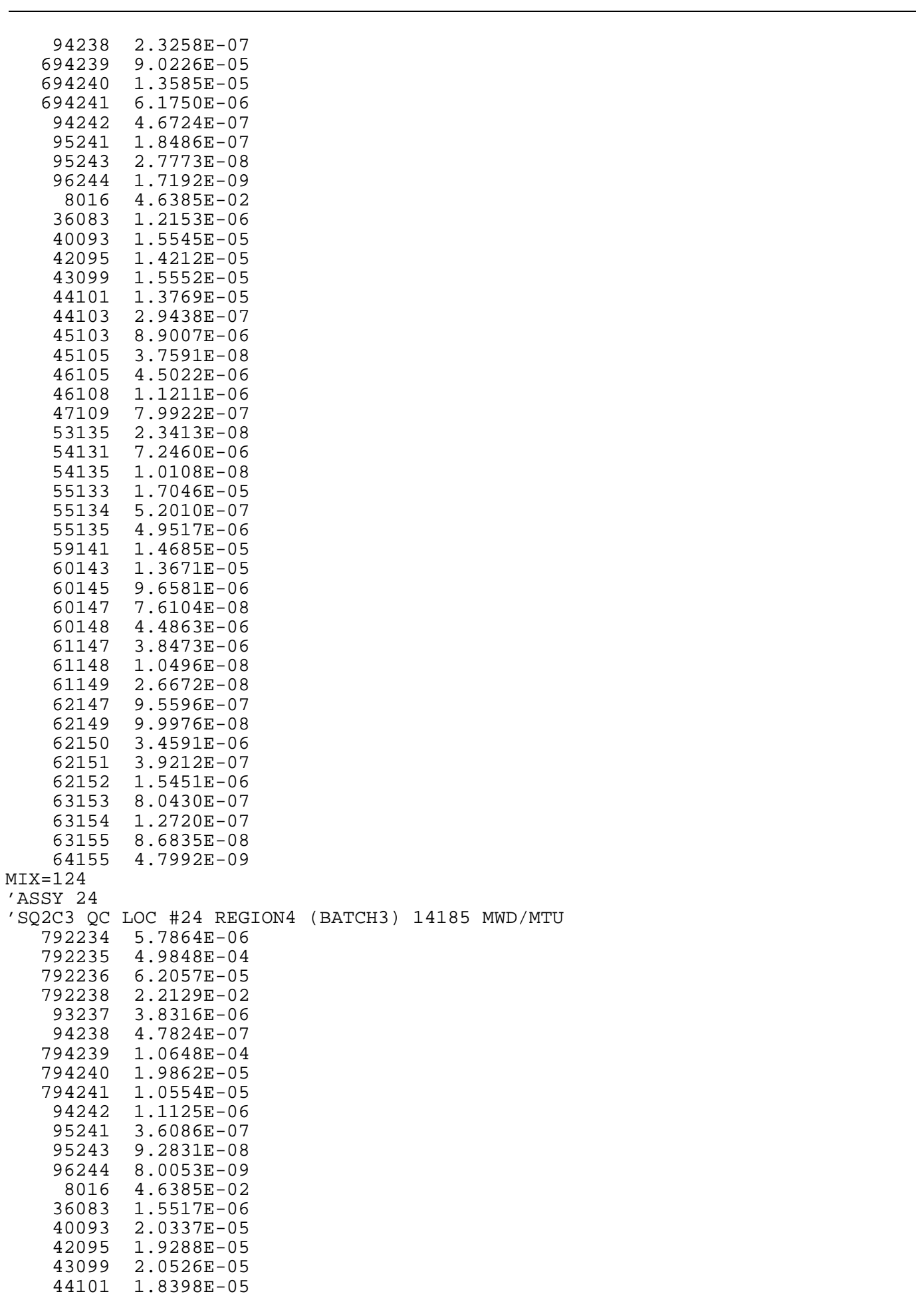


159

Table D.10 (continued)

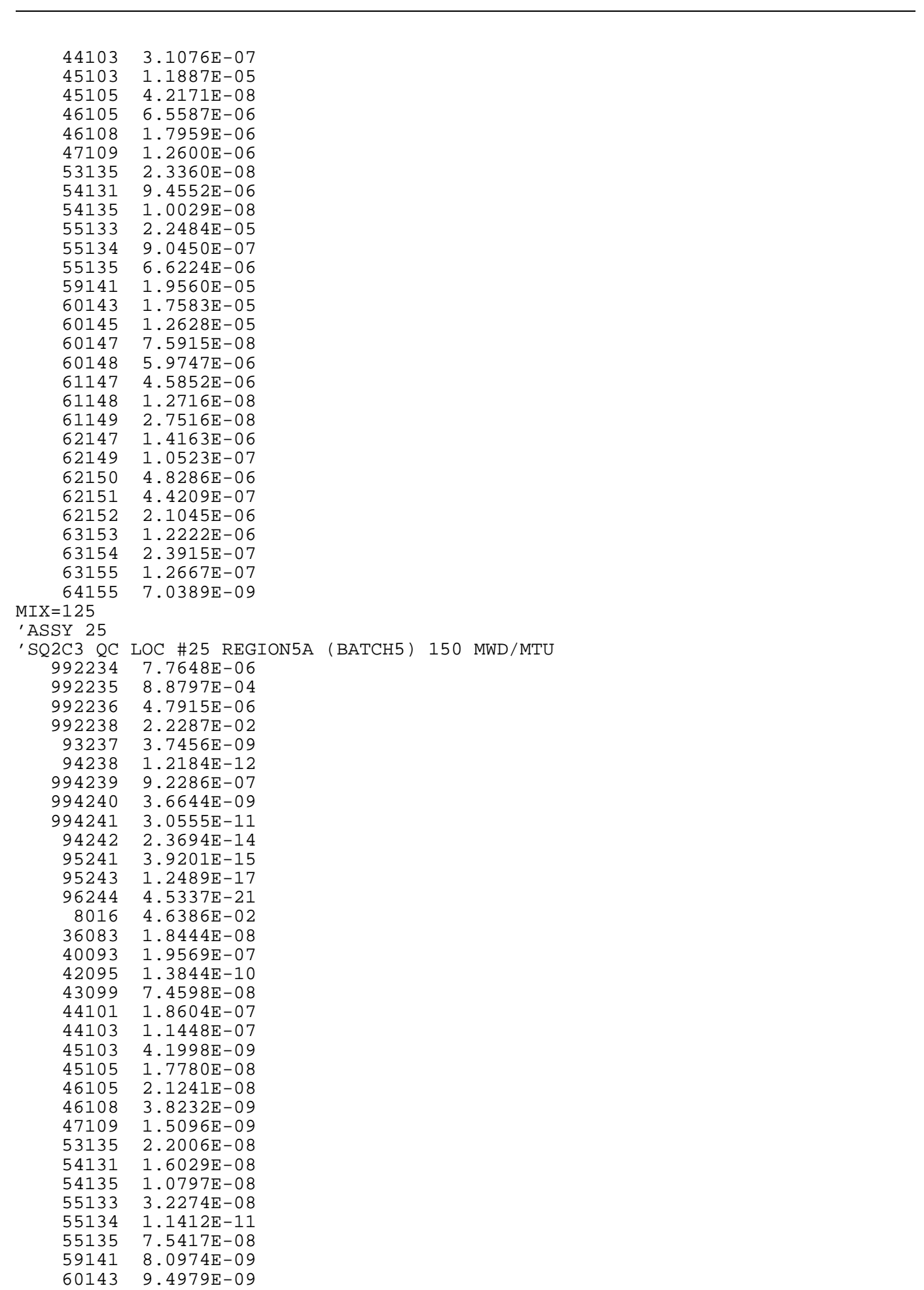


160

Table D.10 (continued)

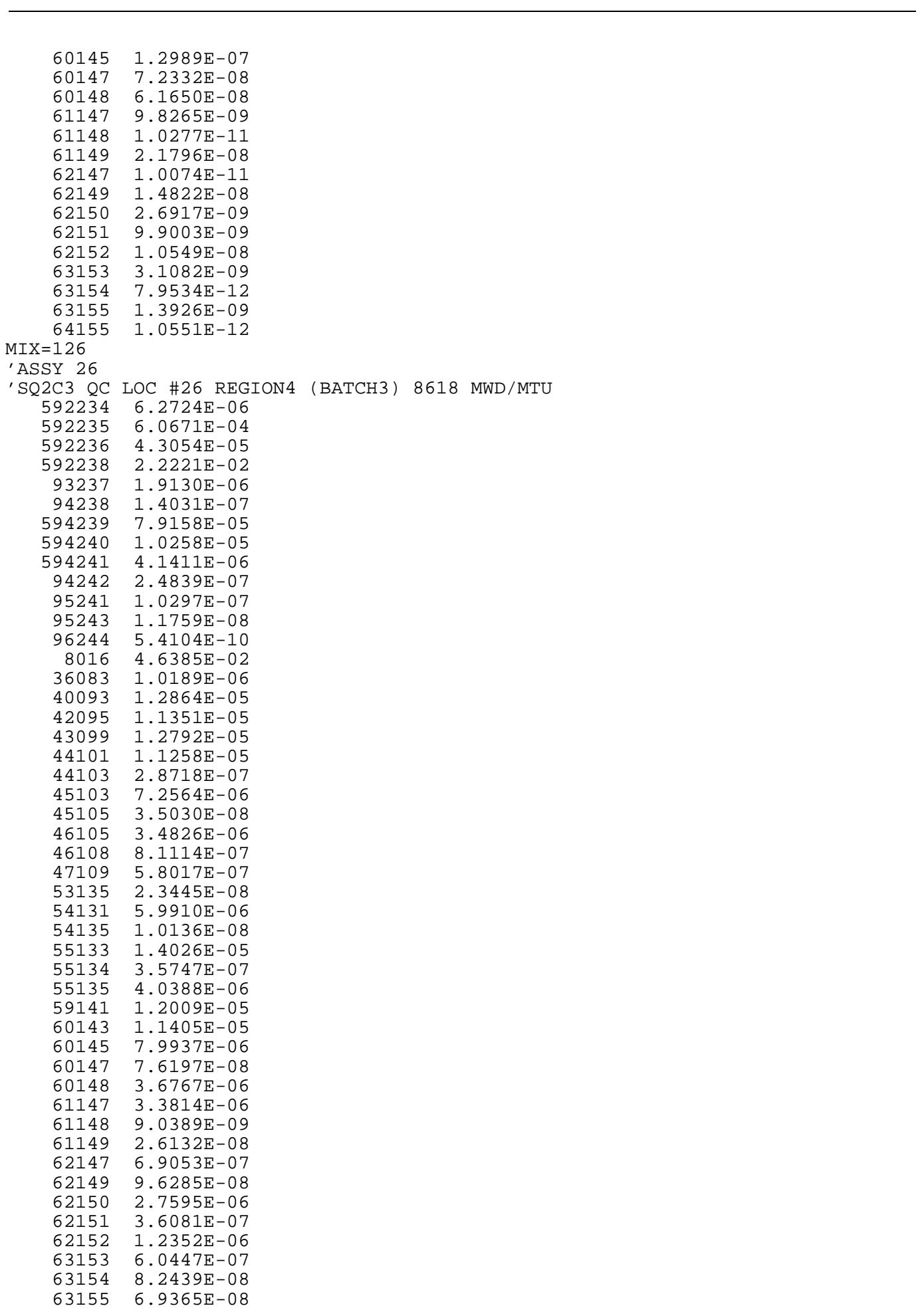


161

Table D.10 (continued)

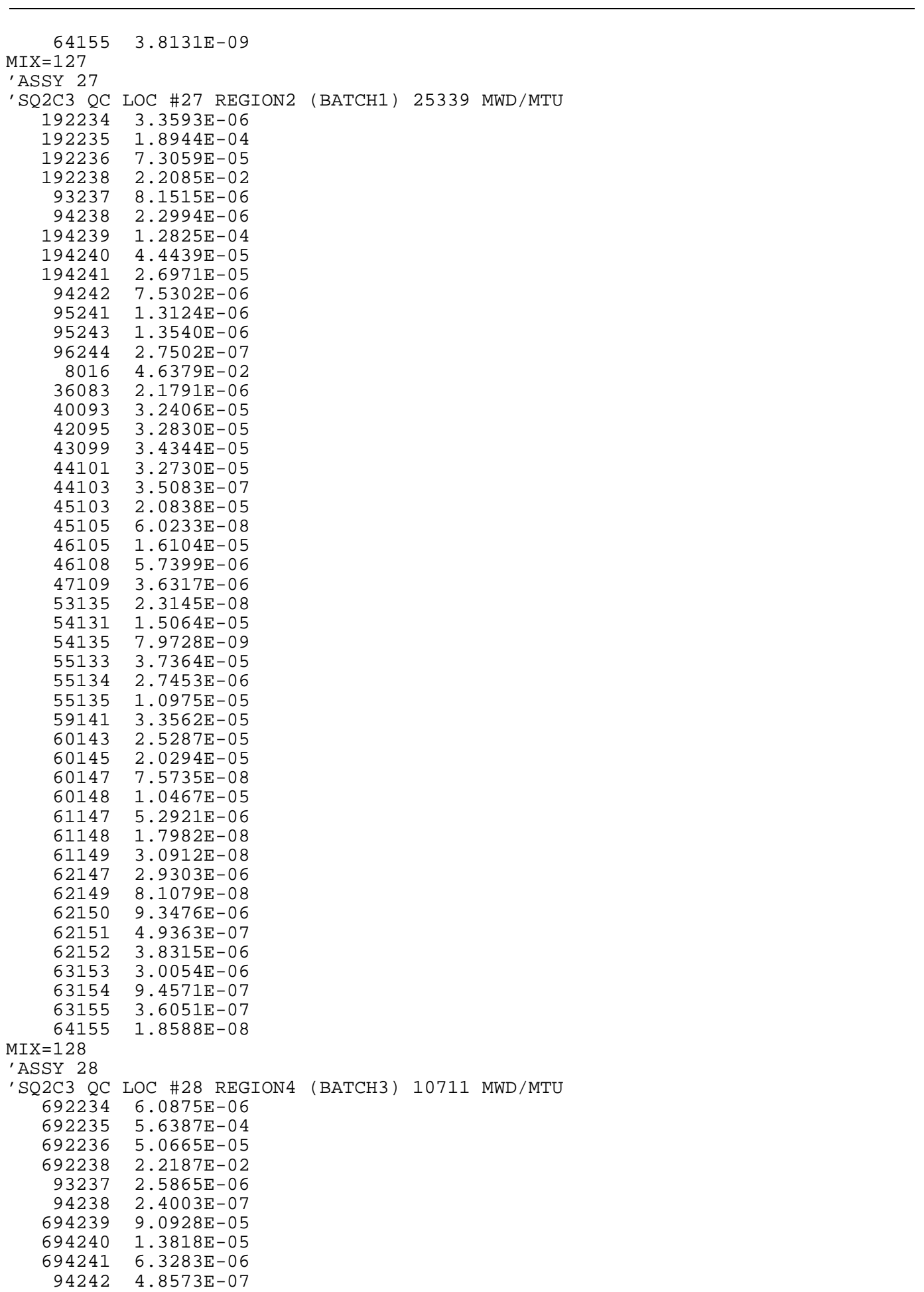


162

Table D.10 (continued)

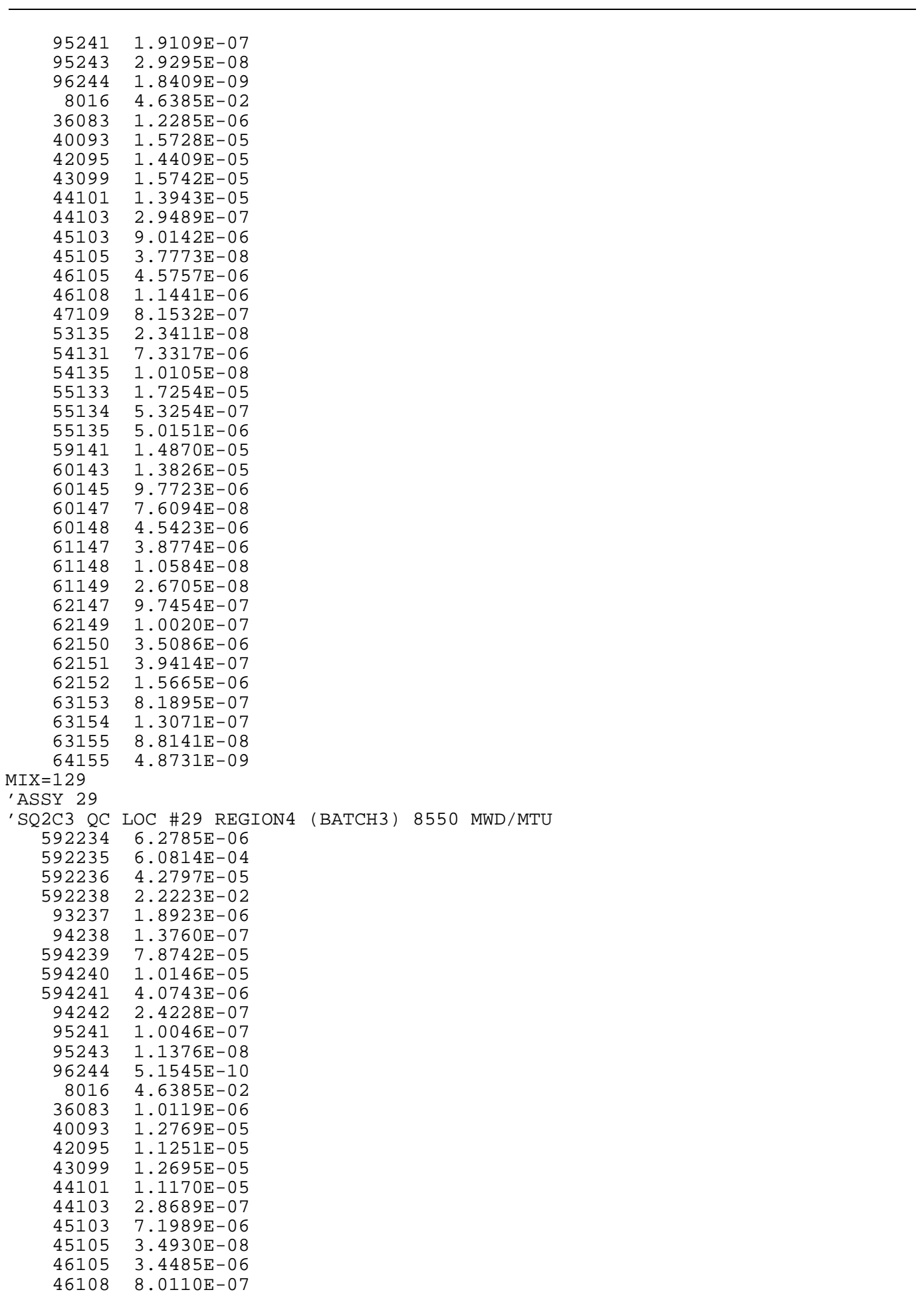


163

Table D.10 (continued)

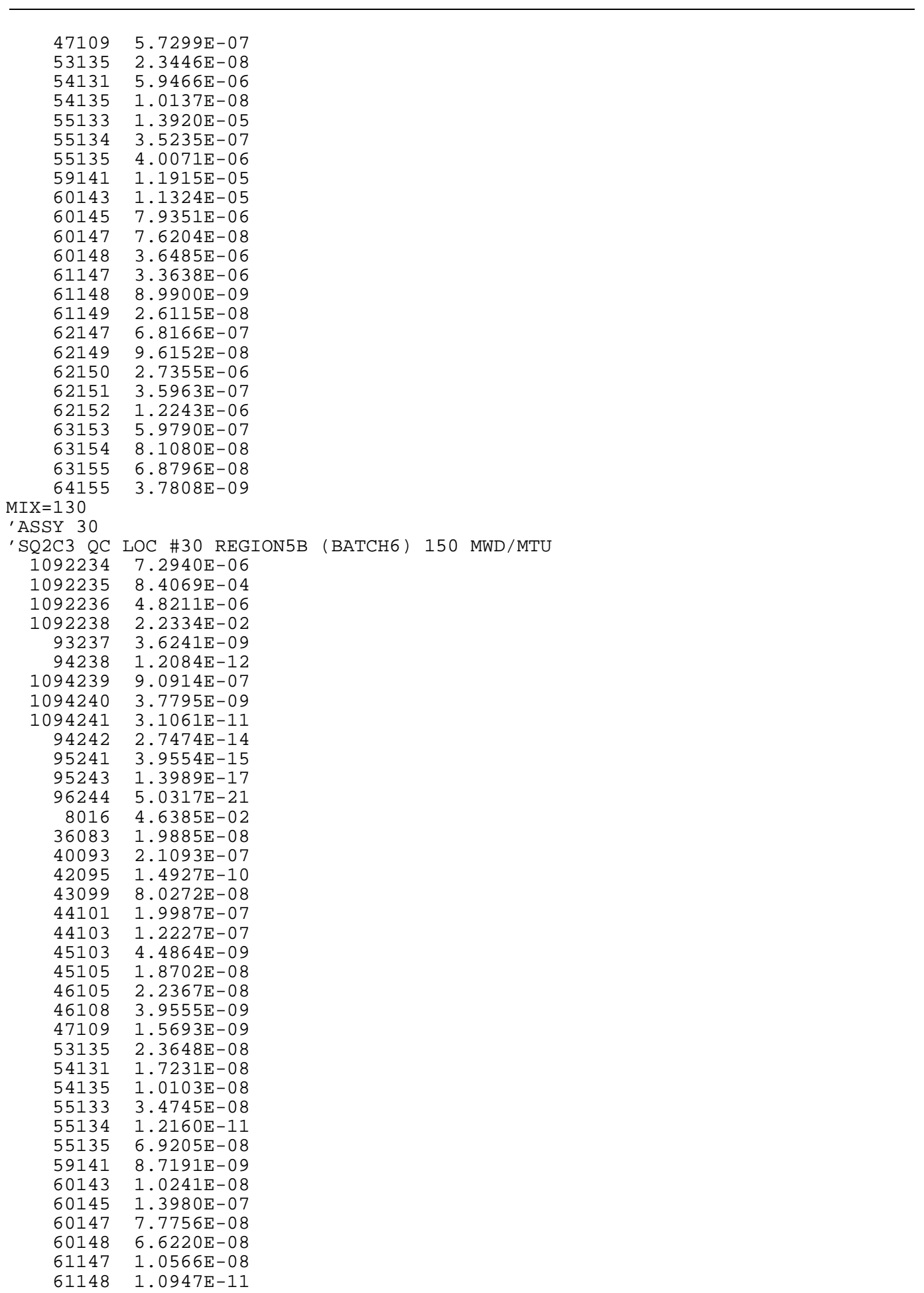


164

Table D.10 (continued)

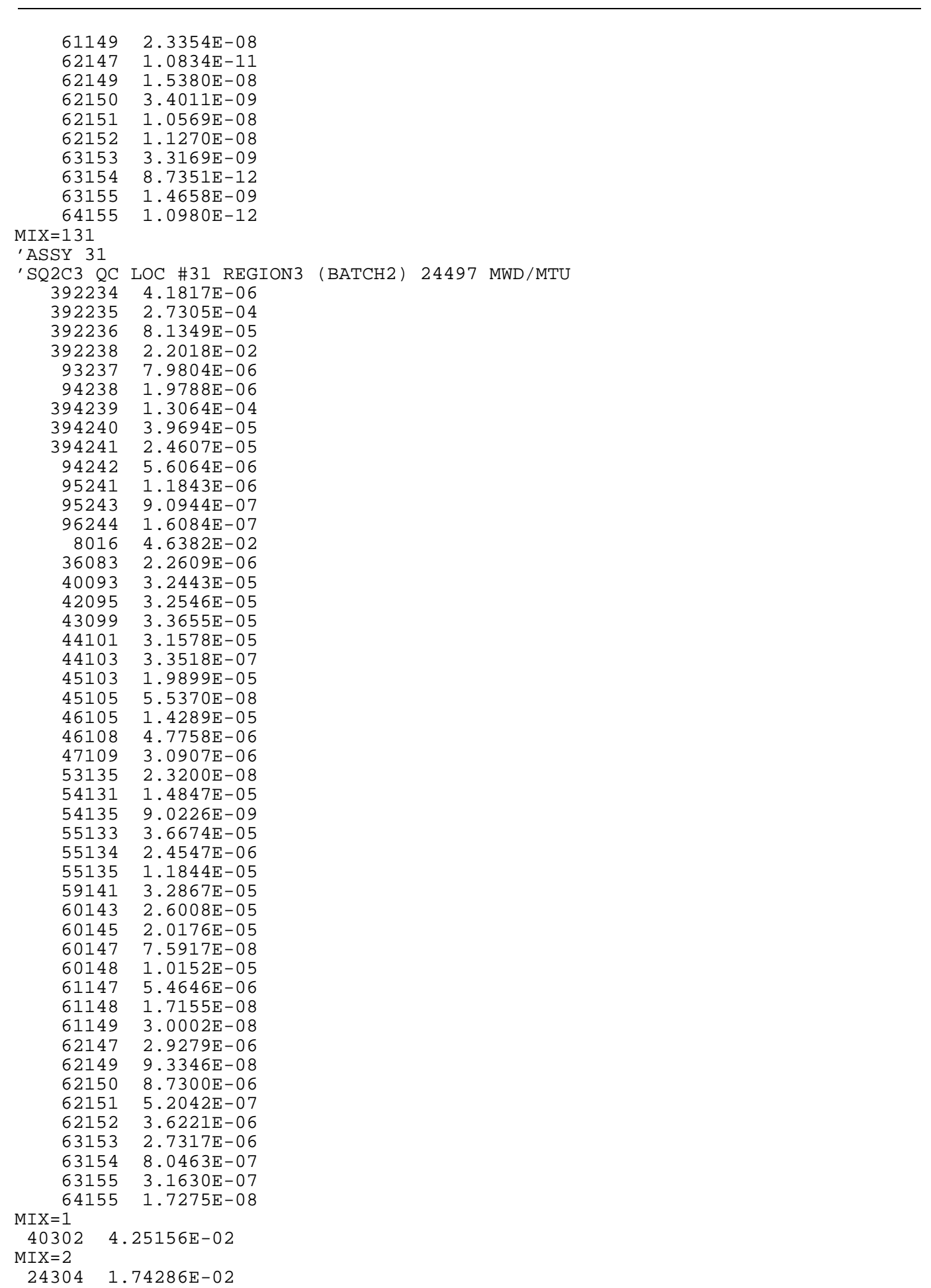


165

Table D.10 (continued)

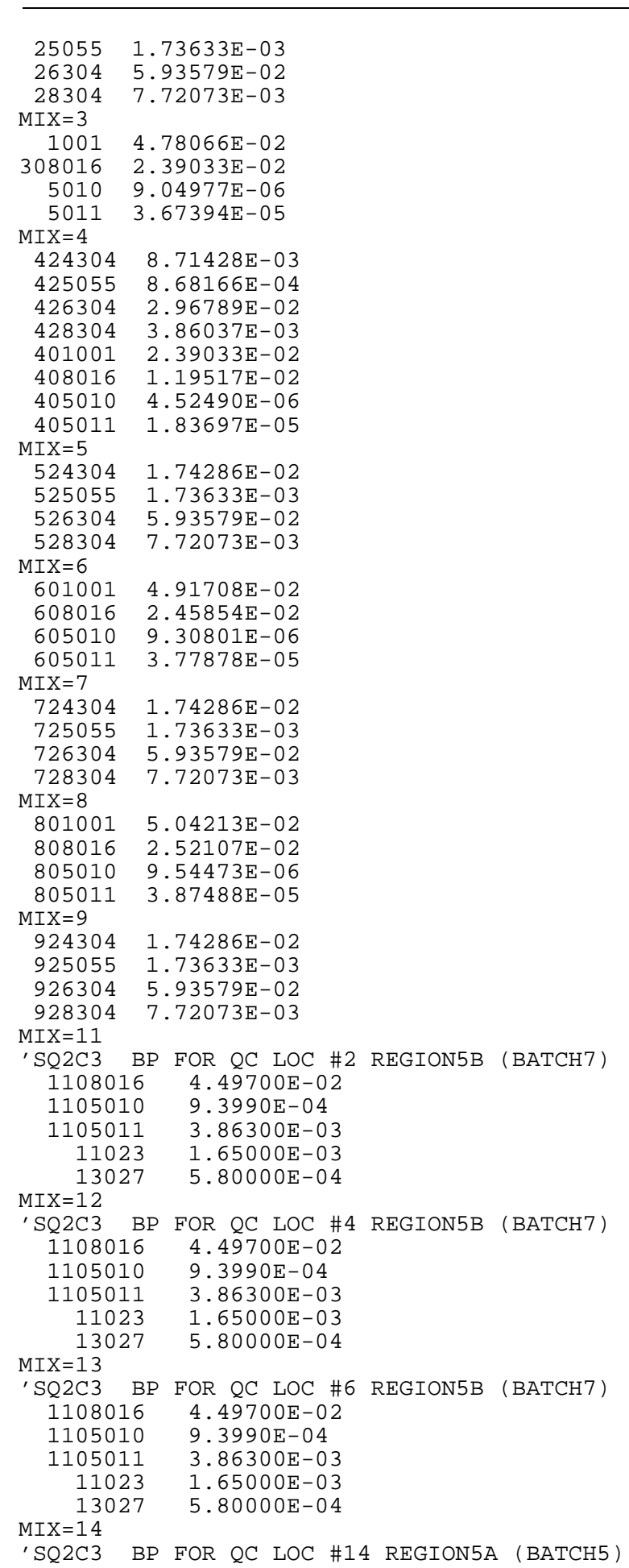


Table D.10 (continued)

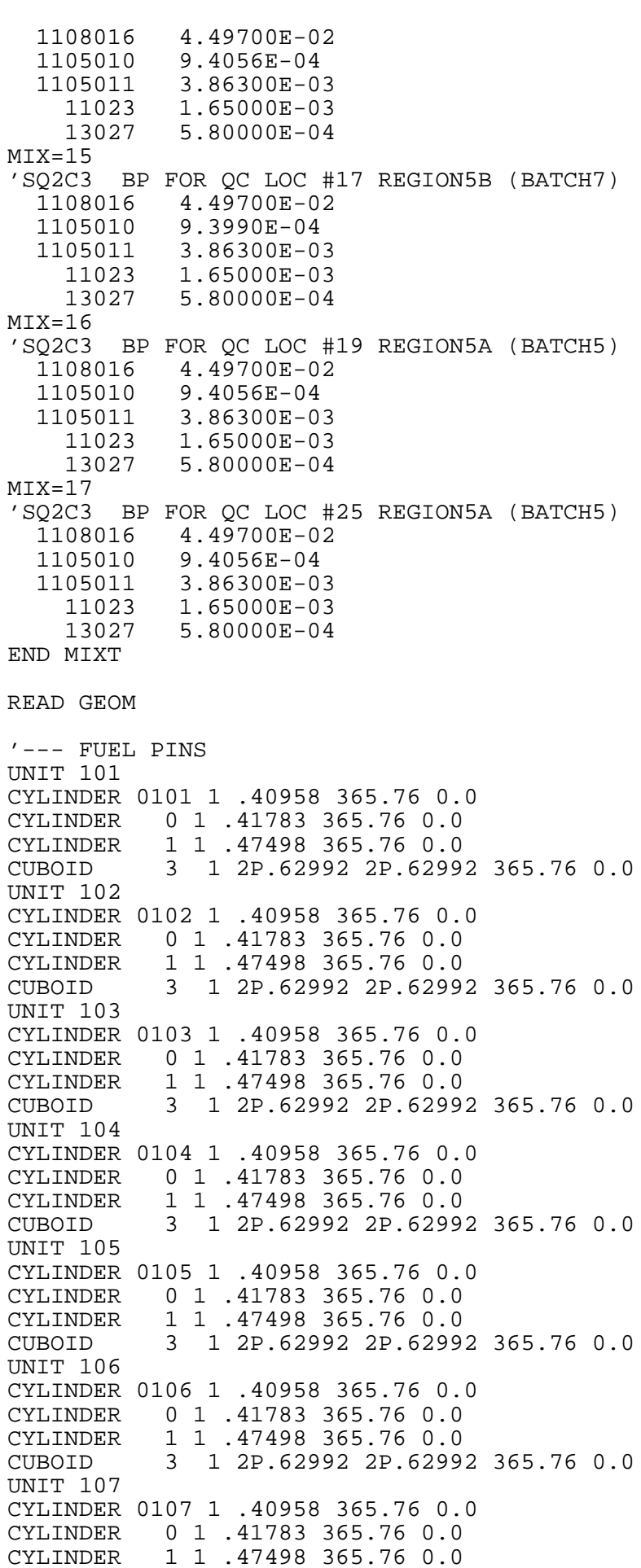


Table D.10 (continued)

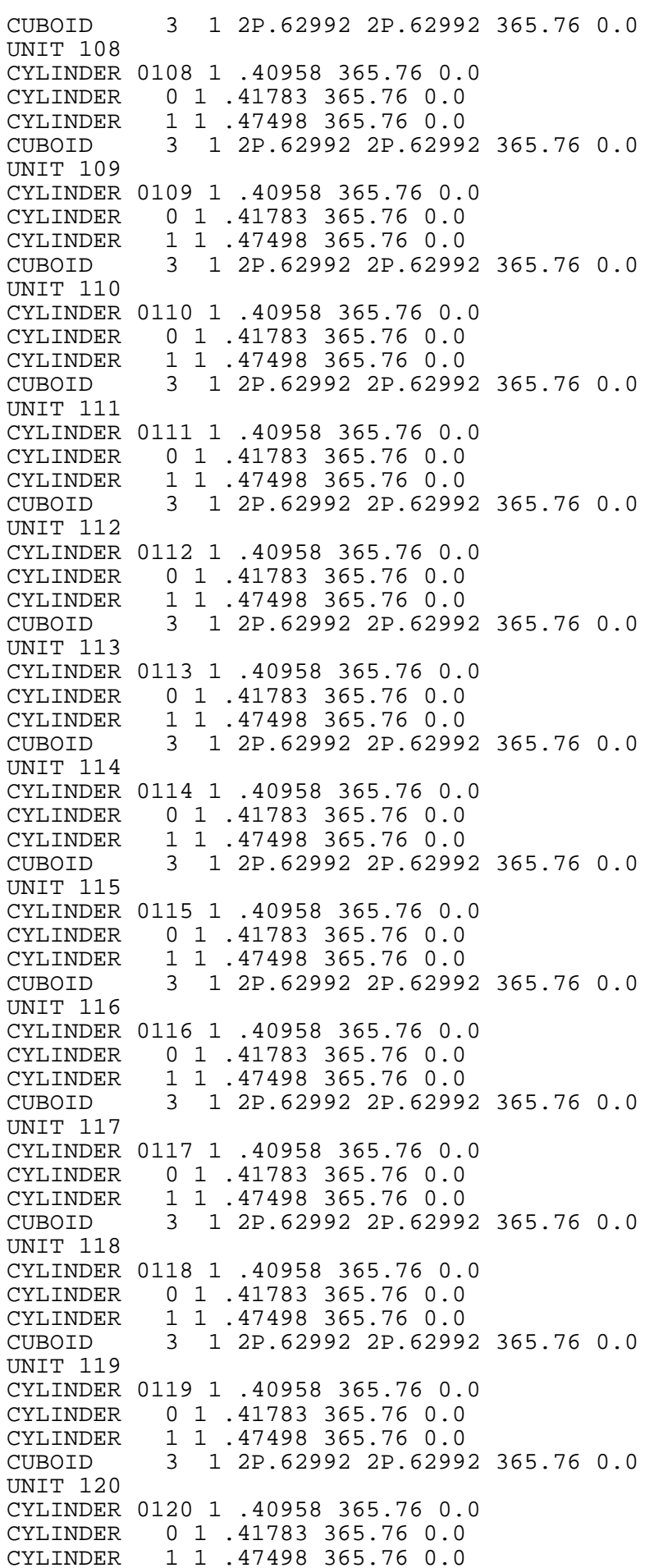


Table D.10 (continued)

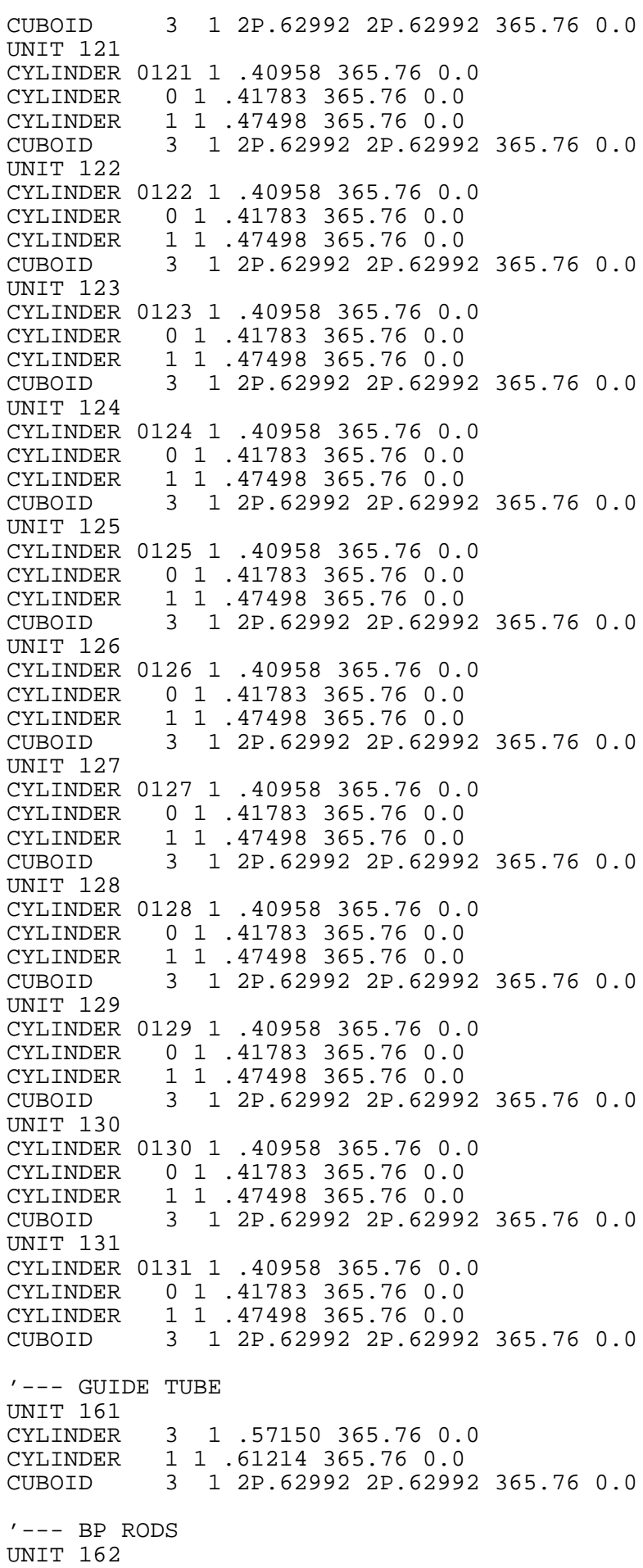


Table D.10 (continued)

\begin{tabular}{|c|c|c|c|c|c|c|}
\hline CYLINDER & 0 & 10.21400 & 365.76 & 0.0 & & \\
\hline CYLINDER & 2 & 10.23051 & 365.76 & 0.0 & & \\
\hline CYLINDER & 0 & 10.24130 & 365.76 & 0.0 & & \\
\hline CYLINDER & 11 & 10.42672 & 365.76 & 0.0 & & \\
\hline CYLINDER & 0 & 10.43688 & 365.76 & 0.0 & & \\
\hline CYLINDER & 2 & 10.48387 & 365.76 & 0.0 & & \\
\hline CYLINDER & 3 & 10.57150 & 365.76 & 0.0 & & \\
\hline CYLINDER & 1 & 10.61214 & 365.76 & 0.0 & & \\
\hline CUBOID & 3 & $12 \mathrm{P} 0.629$ & $9922 \mathrm{P} 0$. & 62992 & 365.76 & 0.0 \\
\hline UNIT 163 & & & & & & \\
\hline CYLINDER & 0 & 10.21400 & 365.76 & 0.0 & & \\
\hline CYLINDER & 2 & 10.23051 & 365.76 & 0.0 & & \\
\hline CYLINDER & 0 & 10.24130 & 365.76 & 0.0 & & \\
\hline CYLINDER & 12 & 10.42672 & 365.76 & 0.0 & & \\
\hline CYLINDER & 0 & 10.43688 & 365.76 & 50.0 & & \\
\hline CYLINDER & 2 & 10.48387 & 365.76 & 0.0 & & \\
\hline CYLINDER & 3 & 10.57150 & 365.76 & 50.0 & & \\
\hline CYLINDER & 1 & 10.61214 & 365.76 & 0.0 & & \\
\hline CUBOID & 3 & $12 \mathrm{P} 0.629$ & 992 2P0. & 62992 & 365.76 & 0.0 \\
\hline UNIT 164 & & & & & & \\
\hline CYLINDER & 0 & 10.21400 & 365.76 & 0.0 & & \\
\hline CYLINDER & 2 & 10.23051 & 365.76 & 0.0 & & \\
\hline CYLINDER & 0 & 10.24130 & 365.76 & 0.0 & & \\
\hline CYLINDER & 13 & 10.42672 & 365.76 & 0.0 & & \\
\hline CYLINDER & 0 & 10.43688 & 365.76 & 0.0 & & \\
\hline CYLINDER & 2 & 10.48387 & 365.76 & 0.0 & & \\
\hline CYLINDER & 3 & 10.57150 & 365.76 & 0.0 & & \\
\hline CYLINDER & 1 & 10.61214 & 365.76 & 0.0 & & \\
\hline CUBOID & 3 & $12 \mathrm{P} 0.629$ & $9922 \mathrm{P} 0$. & 62992 & 365.76 & 0.0 \\
\hline UNIT 165 & & & & & & \\
\hline CYLINDER & 0 & 10.21400 & 365.76 & 0.0 & & \\
\hline CYLINDER & 2 & 10.23051 & 365.76 & 0.0 & & \\
\hline CYLINDER & 0 & 10.24130 & 365.76 & 0.0 & & \\
\hline CYLINDER & 14 & 10.42672 & 365.76 & 0.0 & & \\
\hline CYLINDER & 0 & 10.43688 & 365.76 & 0.0 & & \\
\hline CYLINDER & 2 & 10.48387 & 365.76 & 0.0 & & \\
\hline CYLINDER & 3 & 10.57150 & 365.76 & 0.0 & & \\
\hline CYLINDER & 1 & 10.61214 & 365.76 & 0.0 & & \\
\hline CUBOID & 3 & $12 \mathrm{P} 0.629$ & 992 2P0. & 62992 & 365.76 & 0.0 \\
\hline UNIT 166 & & & & & & \\
\hline CYLINDER & 0 & 10.21400 & 365.76 & 0.0 & & \\
\hline CYLINDER & 2 & 10.23051 & 365.76 & 0.0 & & \\
\hline CYLINDER & 0 & 10.24130 & 365.76 & 0.0 & & \\
\hline CYLINDER & 15 & 10.42672 & 365.76 & 0.0 & & \\
\hline CYLINDER & 0 & 10.43688 & 365.76 & 50.0 & & \\
\hline CYLINDER & 2 & 10.48387 & 365.76 & 0.0 & & \\
\hline CYLINDER & 3 & 10.57150 & 365.76 & 50.0 & & \\
\hline CYLINDER & 1 & 10.61214 & 365.76 & 0.0 & & \\
\hline CUBOID & 3 & $12 \mathrm{P} 0.629$ & $9922 \mathrm{P} 0$. & 62992 & 365.76 & 0.0 \\
\hline UNIT 167 & & & & & & \\
\hline CYLINDER & 0 & 10.21400 & 365.76 & 0.0 & & \\
\hline CYLINDER & 2 & 10.23051 & 365.76 & 0.0 & & \\
\hline CYLINDER & 0 & 10.24130 & 365.76 & 0.0 & & \\
\hline CYLINDER & 16 & 10.42672 & 365.76 & 0.0 & & \\
\hline CYLINDER & 0 & 10.43688 & 365.76 & 0.0 & & \\
\hline CYLINDER & 2 & 10.48387 & 365.76 & 0.0 & & \\
\hline CYLINDER & 3 & 10.57150 & 365.76 & 50.0 & & \\
\hline CYLINDER & 1 & 10.61214 & 365.76 & 0.0 & & \\
\hline CUBOID & 3 & $12 \mathrm{P} 0.629$ & 992 2P0. & 62992 & 365.76 & 0.0 \\
\hline UNIT 168 & & & & & & \\
\hline CYLINDER & 0 & 10.21400 & 365.76 & 0.0 & & \\
\hline CYLINDER & 2 & 10.23051 & 365.76 & 0.0 & & \\
\hline CYLINDER & 0 & 10.24130 & 365.76 & 0.0 & & \\
\hline CYLINDER & 17 & 10.42672 & 365.76 & 0.0 & & \\
\hline CYLINDER & 0 & 10.43688 & .76 & 50.0 & & \\
\hline
\end{tabular}


Table D.10 (continued)

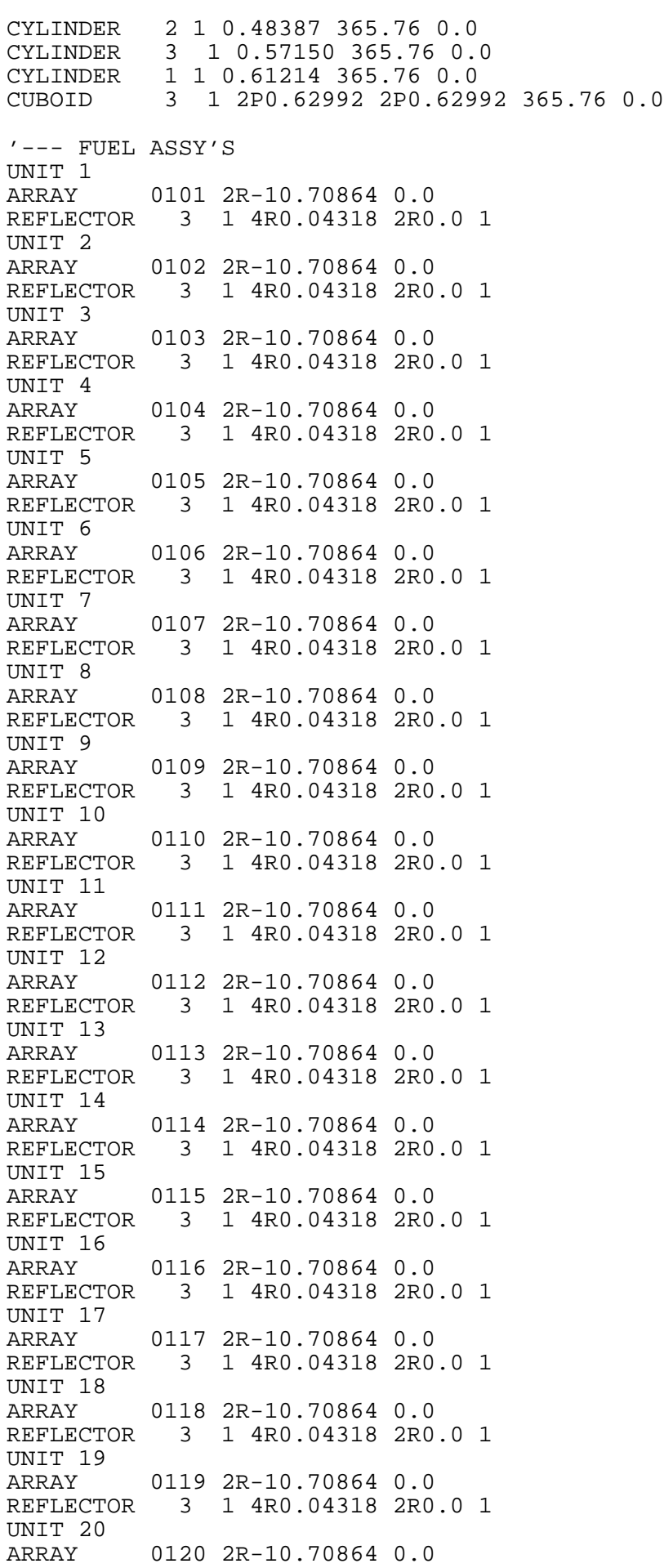


Table D.10 (continued)

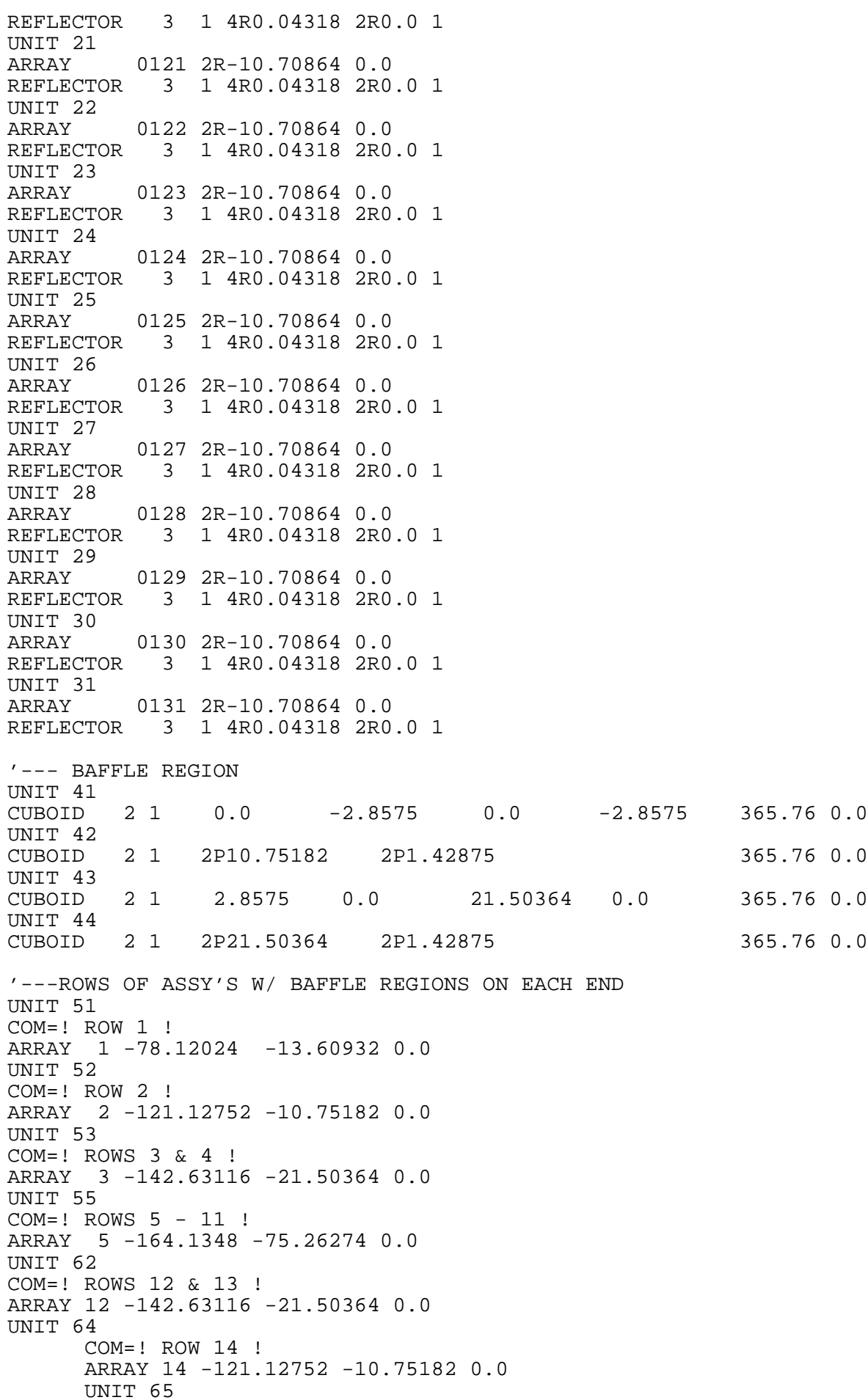


Table D.10 (continued)

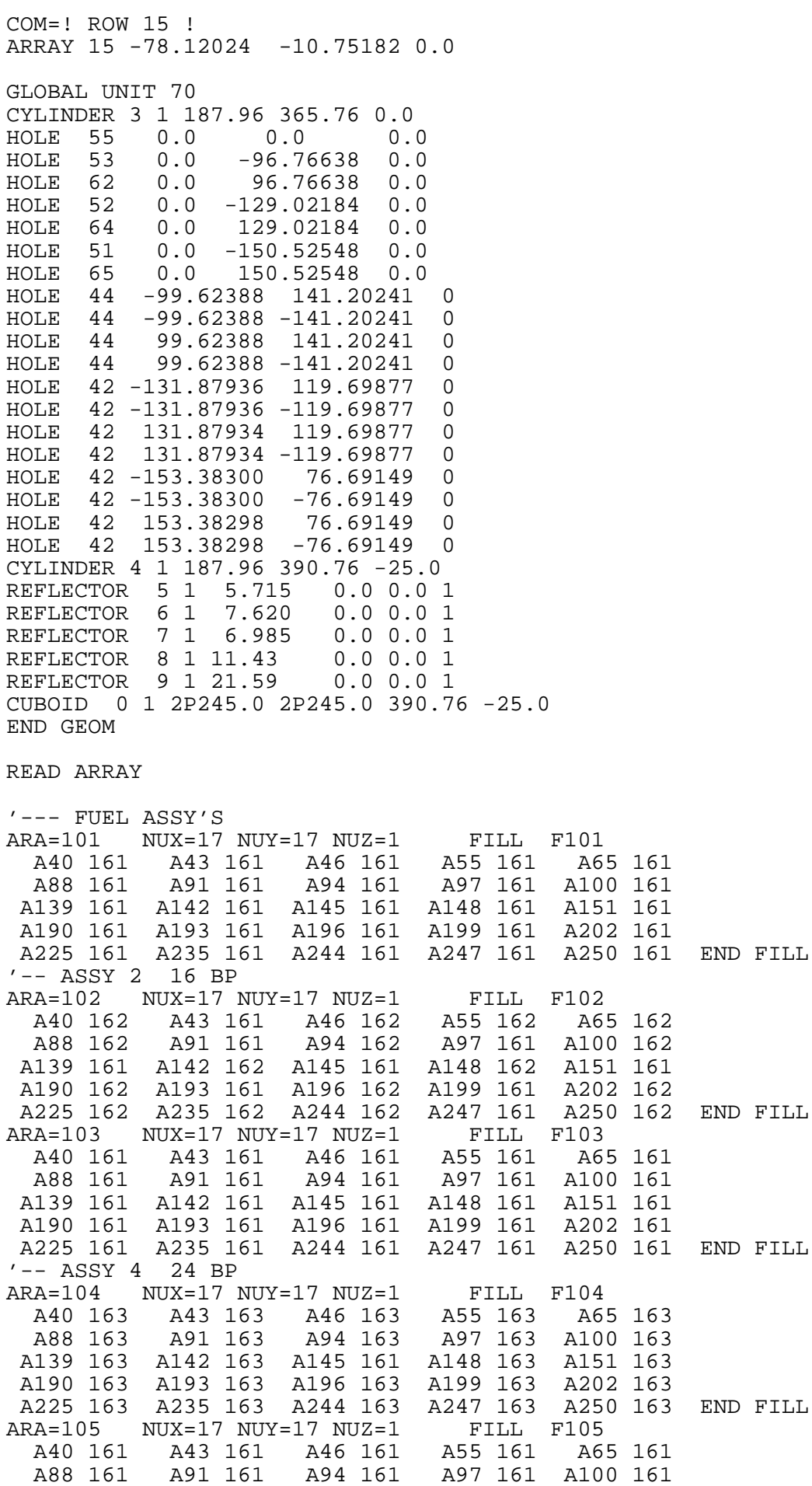


Table D.10 (continued)

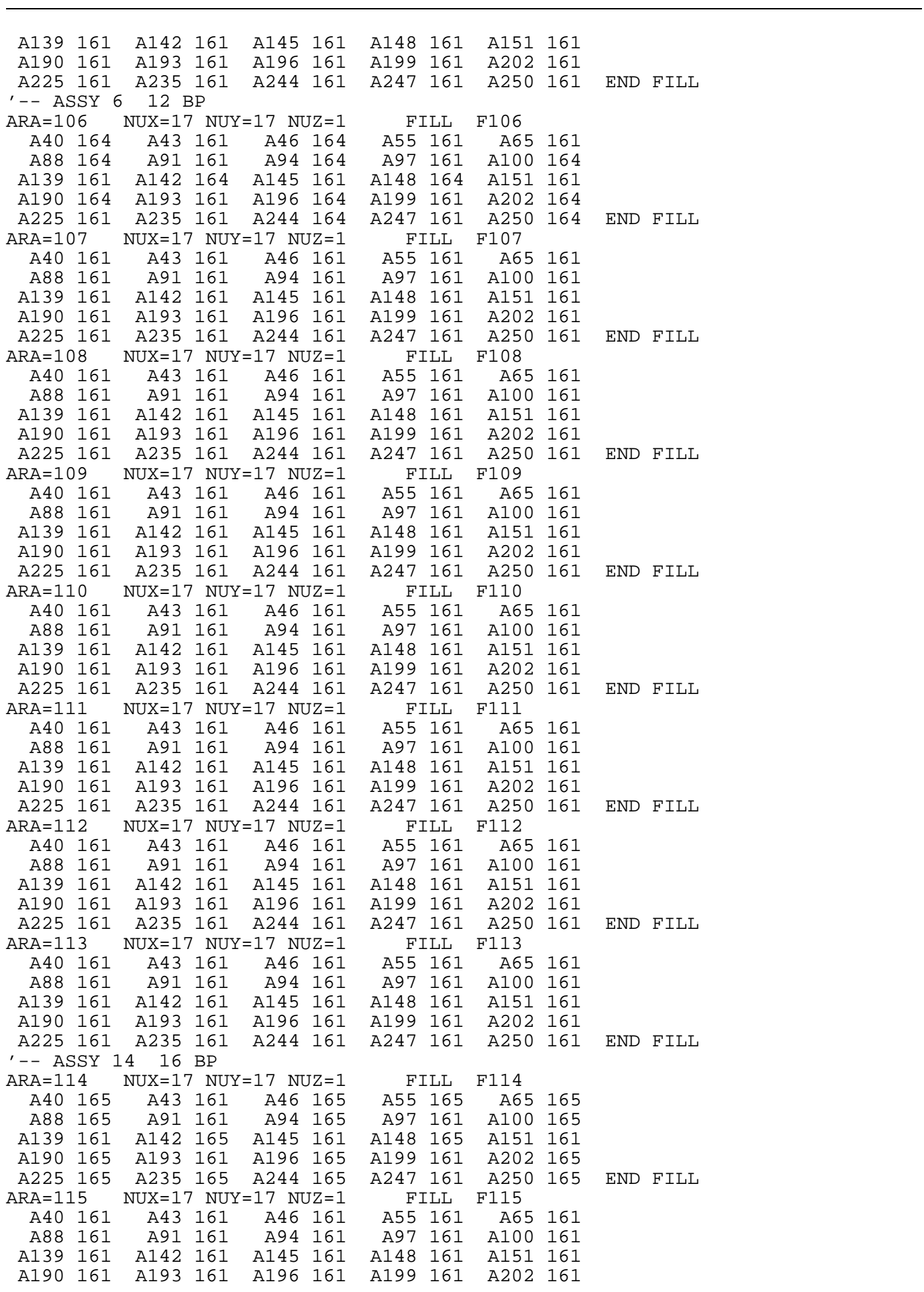


174

Table D.10 (continued)

\begin{tabular}{|c|c|c|c|c|c|c|c|c|c|c|c|}
\hline A22 5 & 161 & A235 & 161 & A2 44 & 161 & A2 47 & 161 & A2 50 & 161 & END & FILL \\
\hline $\mathrm{ARA}=11$ & & $N U X=17$ & NUY & $=17 \mathrm{NL}$ & $I U Z=1$ & & $\mathrm{LL}$ & F116 & & & \\
\hline A 40 & 161 & A43 & 161 & A 46 & 161 & A 55 & 161 & A 65 & 161 & & \\
\hline A8 8 & 161 & A91 & 161 & A94 & 161 & A9 7 & 161 & A100 & 161 & & \\
\hline A139 & 161 & A1 42 & 161 & A1 45 & 161 & A1 48 & 161 & A151 & 161 & & \\
\hline A190 & 161 & A193 & 161 & A196 & 161 & A199 & 161 & A202 & 161 & & \\
\hline A 225 & 161 & A235 & 161 & A2 44 & 161 & A2 47 & 161 & A 250 & 161 & END & FILL \\
\hline \multicolumn{12}{|c|}{ '-- ASSY $17 \quad 12$ BP } \\
\hline \multicolumn{2}{|c|}{$\mathrm{ARA}=117$} & \multicolumn{2}{|c|}{$\mathrm{NUX}=17 \mathrm{NU}$} & \multicolumn{2}{|c|}{$\mathrm{NUZ}=1$} & \multicolumn{2}{|c|}{ FILL } & \multicolumn{2}{|l|}{ F 117} & & \\
\hline A 40 & 166 & A43 & 161 & A 46 & 166 & A5 5 & 161 & A 65 & 161 & & \\
\hline A 88 & 166 & A91 & 161 & A94 & 166 & A 97 & 161 & $\mathrm{~A} 100$ & 166 & & \\
\hline A139 & 161 & A 142 & 166 & A145 & 161 & A148 & 166 & A151 & 161 & & \\
\hline A190 & 166 & A193 & 161 & A196 & 166 & A199 & 161 & A202 & 166 & & \\
\hline A225 & 161 & A235 & 161 & A2 44 & 166 & A2 47 & 161 & A250 & 166 & END & FILL \\
\hline \multicolumn{2}{|c|}{$\mathrm{ARA}=118$} & $\mathrm{NUX}=17$ & \multicolumn{3}{|c|}{$7 \quad \mathrm{NUY}=17 \quad \mathrm{NUZ}=1$} & \multicolumn{2}{|c|}{ FILL } & \multicolumn{2}{|l|}{ F118 } & & \\
\hline A40 & 161 & A 43 & 161 & A 46 & 161 & A 55 & 161 & A 65 & 161 & & \\
\hline A88 & 161 & A91 & 161 & A94 & 161 & A9 7 & 161 & A100 & 161 & & \\
\hline A139 & 161 & $\mathrm{~A} 142$ & 161 & A145 & 161 & A1 48 & 161 & A151 & 161 & & \\
\hline A190 & 161 & A193 & 161 & A196 & 161 & A199 & 161 & A202 & 161 & & \\
\hline A 225 & 161 & A235 & 161 & A2 44 & 161 & A2 47 & 161 & A2 50 & 161 & END & FILL \\
\hline$'--A S$ & SSY & 1920 & $\mathrm{BP}$ & & & & & & & & \\
\hline $\mathrm{ARA}=11$ & & $\mathrm{NUX}=17$ & NUY & $=17 \mathrm{NL}$ & $\mathrm{UZ}=1$ & & $\mathrm{LL}$ & F119 & & & \\
\hline A40 & 167 & A43 & 167 & A4 6 & 167 & A 55 & 167 & A 65 & 167 & & \\
\hline A 88 & 167 & A91 & 161 & A94 & 167 & A 97 & 161 & A 100 & 167 & & \\
\hline A139 & 167 & A1 42 & 167 & A145 & 161 & A1 48 & 167 & A151 & 167 & & \\
\hline A190 & 167 & A193 & 161 & A196 & 167 & A199 & 161 & A202 & 167 & & \\
\hline A225 & 167 & A235 & 167 & A2 44 & 167 & A2 47 & 167 & A250 & 167 & END & FILL \\
\hline $\mathrm{ARA}=12$ & & $N U X=17$ & NUY & $=17 \mathrm{NL}$ & $\mathrm{UZ}=1$ & & $\mathrm{LL}$ & F120 & & & \\
\hline A4 0 & 161 & A43 & 161 & A4 6 & 161 & A5 5 & 161 & A 65 & 161 & & \\
\hline A88 & 161 & A91 & 161 & A94 & 161 & A 97 & 161 & A100 & 161 & & \\
\hline A139 & 161 & $\mathrm{~A} 142$ & 161 & A145 & 161 & A148 & 161 & A151 & 161 & & \\
\hline A190 & 161 & A193 & 161 & A196 & 161 & A199 & 161 & A202 & 161 & & \\
\hline A 225 & 161 & A235 & 161 & A2 44 & 161 & A2 47 & 161 & A 250 & 161 & END & FILL \\
\hline $\mathrm{ARA}=12$ & & $\mathrm{NUX}=17$ & NUY & $=17 \mathrm{NL}$ & $\mathrm{UZ}=1$ & & $\mathrm{LL}$ & F121 & & & \\
\hline A40 & 161 & A43 & 161 & A 46 & 161 & A 55 & 161 & A65 & 161 & & \\
\hline A 88 & 161 & A91 & 161 & A94 & 161 & A 97 & 161 & A100 & 161 & & \\
\hline A139 & 161 & A1 42 & 161 & A145 & 161 & A148 & 161 & A151 & 161 & & \\
\hline A190 & 161 & A193 & 161 & A196 & 161 & A199 & 161 & A202 & 161 & & \\
\hline A225 & 161 & A235 & 161 & A2 44 & 161 & A2 47 & 161 & A2 50 & 161 & END & FILL \\
\hline $\mathrm{ARA}=12$ & & $\mathrm{NUX}=17$ & NUY & $=17 \mathrm{NL}$ & $\mathrm{UZ}=1$ & & LL & F122 & & & \\
\hline A 40 & 161 & A43 & 161 & A 46 & 161 & A5 5 & 161 & A 65 & 161 & & \\
\hline A 88 & 161 & A91 & 161 & A94 & 161 & A97 & 161 & A 100 & 161 & & \\
\hline A139 & 161 & A142 & 161 & A145 & 161 & A148 & 161 & A151 & 161 & & \\
\hline A190 & 161 & A193 & 161 & A196 & 161 & A199 & 161 & A 202 & 161 & & \\
\hline A22 5 & 161 & A235 & 161 & A2 44 & 161 & A2 47 & 161 & A250 & 161 & END & FILL \\
\hline$A R A=12$ & & $\mathrm{NUX}=17$ & NUY & $=17 \mathrm{NL}$ & $\mathrm{UZ}=1$ & & $\mathrm{LL}$ & F123 & & & \\
\hline A4 0 & 161 & A43 & 161 & A 46 & 161 & A5 5 & 161 & A 65 & 161 & & \\
\hline A 88 & 161 & A91 & 161 & A94 & 161 & A99 & 161 & A100 & 161 & & \\
\hline A139 & 161 & A142 & 161 & A145 & 161 & A1 48 & 161 & A151 & 161 & & \\
\hline A190 & 161 & A193 & 161 & A196 & 161 & A199 & 161 & A202 & 161 & & \\
\hline A22 5 & 161 & A235 & 161 & A2 44 & 161 & A2 47 & 161 & A2 50 & 161 & END & FILL \\
\hline $\mathrm{ARA}=12$ & & $N U X=17$ & NUY & $=17 \mathrm{NL}$ & $\mathrm{UZ}=1$ & & LL & F124 & & & \\
\hline A 40 & 161 & A 43 & 161 & A4 6 & 161 & A 55 & 161 & A 65 & 161 & & \\
\hline A 88 & 161 & A91 & 161 & A94 & 161 & A97 & 161 & A100 & 161 & & \\
\hline A139 & 161 & $\mathrm{~A} 142$ & 161 & A145 & 161 & A148 & 161 & A151 & 161 & & \\
\hline A190 & 161 & A193 & 161 & A196 & 161 & A199 & 161 & A 202 & 161 & & \\
\hline A22 5 & 161 & A235 & 161 & A2 44 & 161 & A2 47 & 161 & A2 50 & 161 & END & FILL \\
\hline$\prime--A S$ & SSY & $258 \mathrm{~B}$ & & & & & & & & & \\
\hline $\mathrm{ARA}=12$ & & $\mathrm{NUX}=17$ & NUY & $17 \mathrm{NL}$ & $\mathrm{UZ}=1$ & & $\mathrm{LL}$ & F125 & & & \\
\hline A 40 & 161 & A43 & 161 & A 46 & 161 & A 55 & 168 & A 65 & 168 & & \\
\hline A88 & 161 & A91 & 161 & A94 & 168 & A9 7 & 161 & A100 & 161 & & \\
\hline A139 & 161 & A142 & 168 & A145 & 161 & A1 48 & 168 & A151 & 161 & & \\
\hline A190 & 161 & A193 & 161 & A196 & 168 & A199 & 161 & A202 & 161 & & \\
\hline A22 5 & 168 & A235 & 168 & A2 44 & 161 & A2 47 & 161 & A2 50 & 161 & END & FILL \\
\hline $\mathrm{ARA}=12$ & & $N U X=17$ & NUY & $=17 \mathrm{NL}$ & $\mathrm{UZ}=1$ & FI & $\mathrm{LL}$ & F126 & & & \\
\hline
\end{tabular}


Table D.10 (continued)

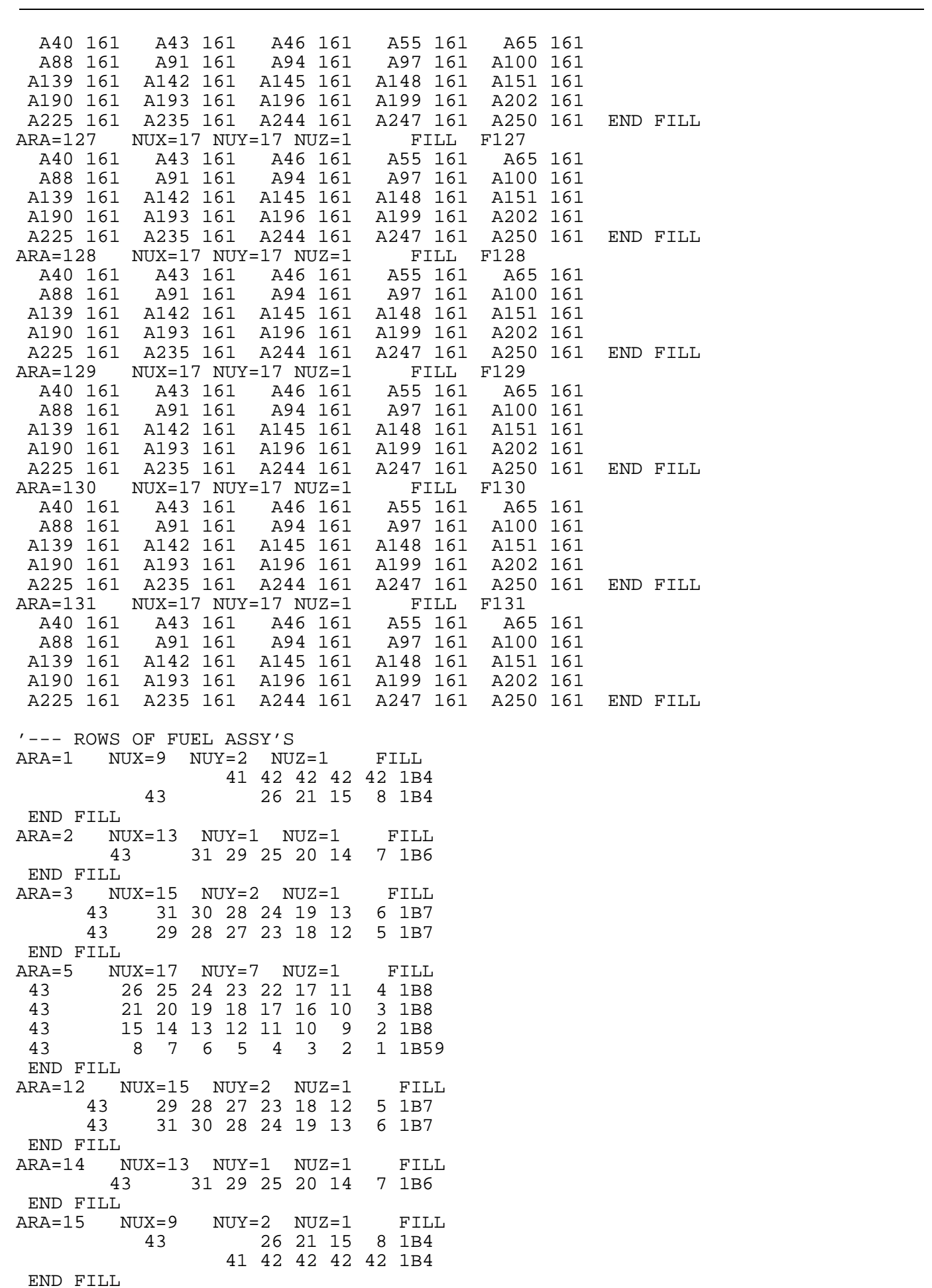


Table D.10 (continued)

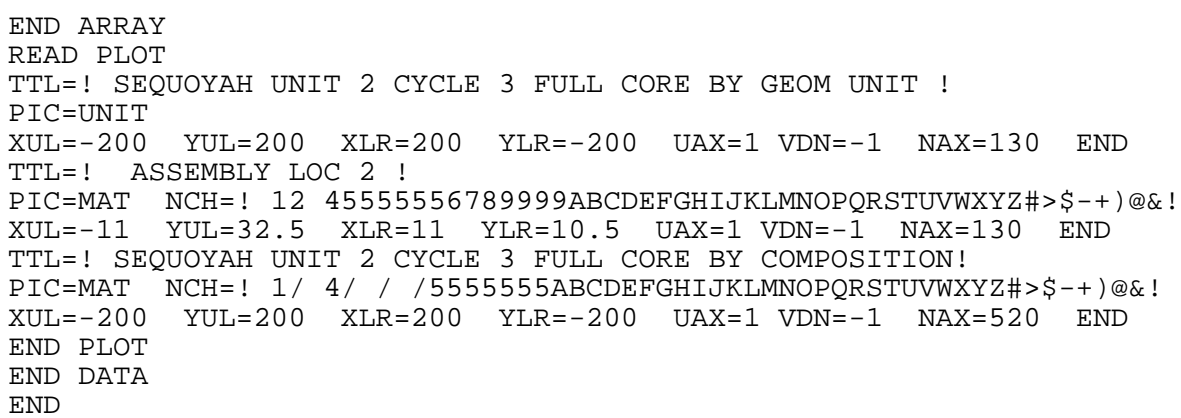


APPENDIX E

KENO V.a MOC MODEL SETUP INPUT EXAMPLES

This appendix gives examples of the input for the different calculational steps for setting up the KENO V.a model for MOC (HFP). 
Table E.1. SNIKR/ORIGEN-S input for fuel assembly isotopics

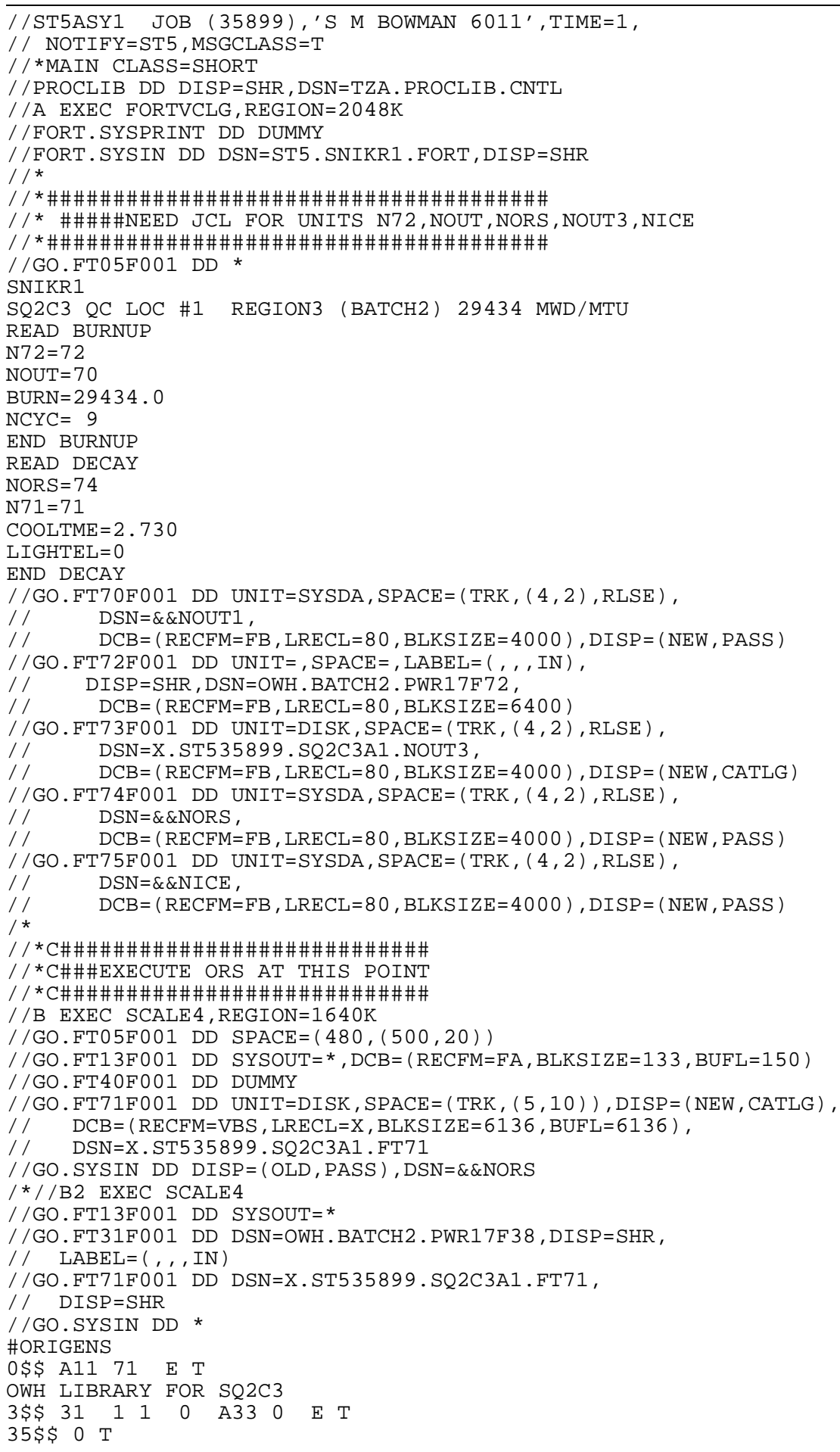


Table E.1 (continued)

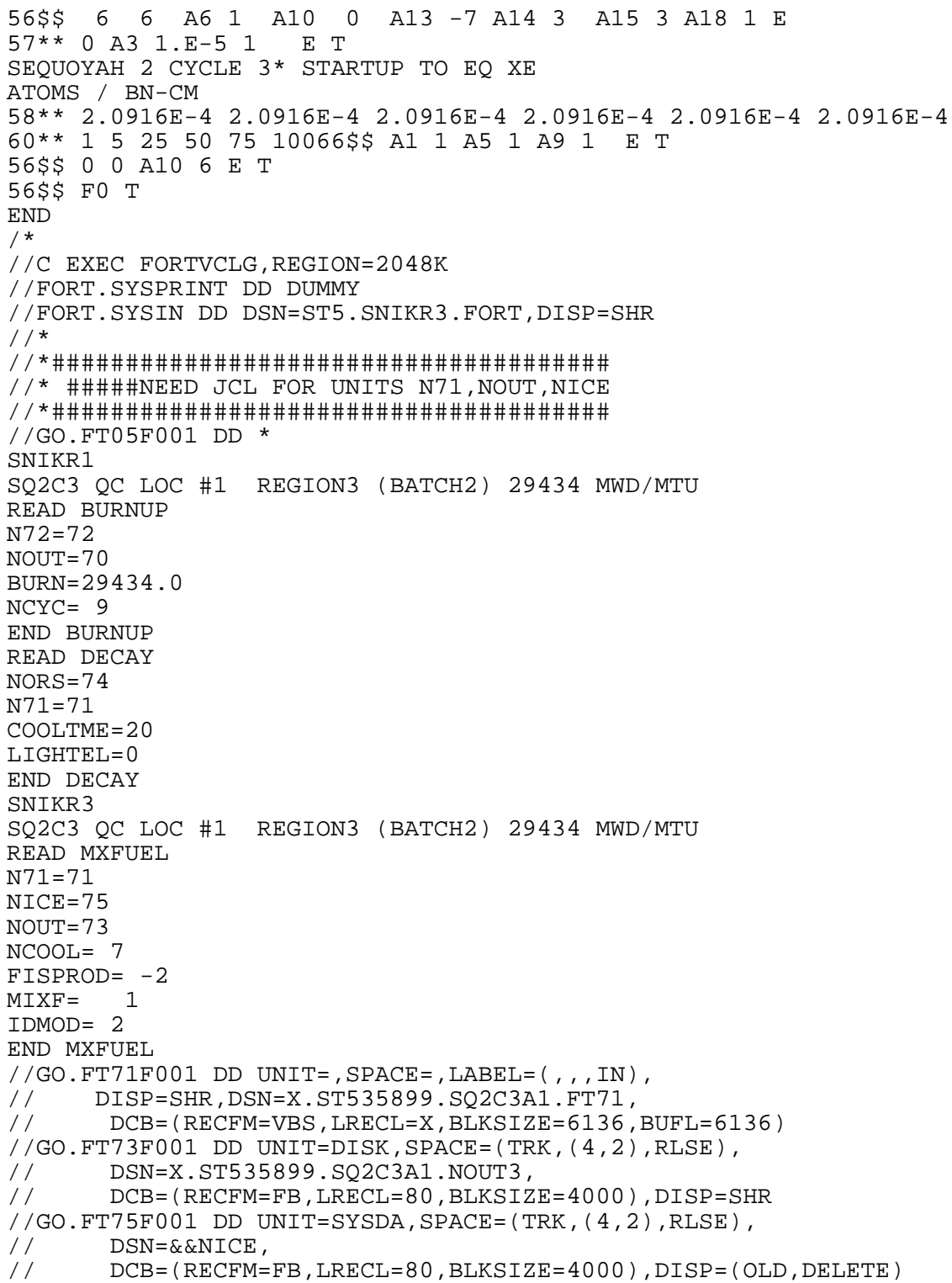


Table E.2. SNIKR/ORIGEN-S input for BP isotopics

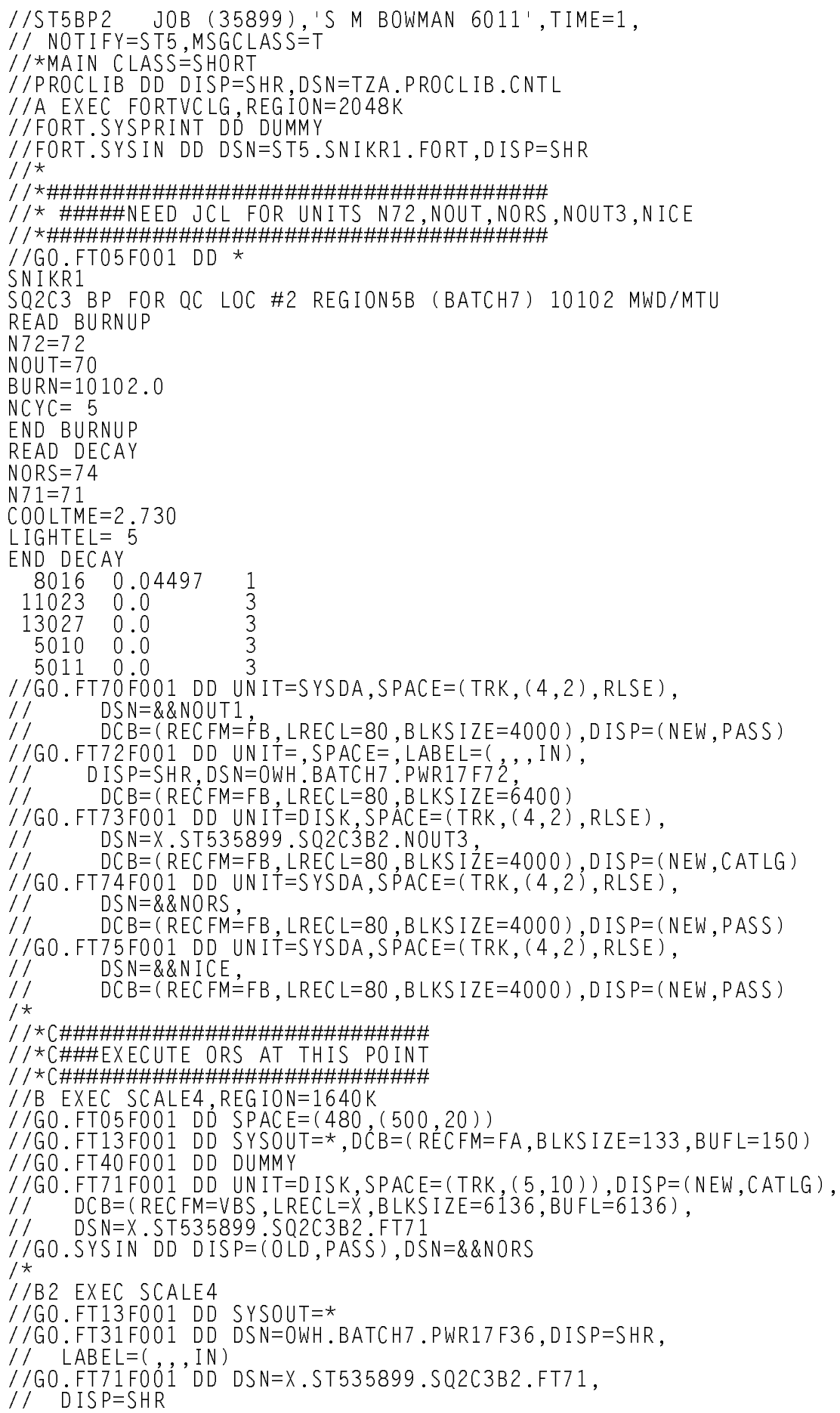


181

Table E.2 (continued)

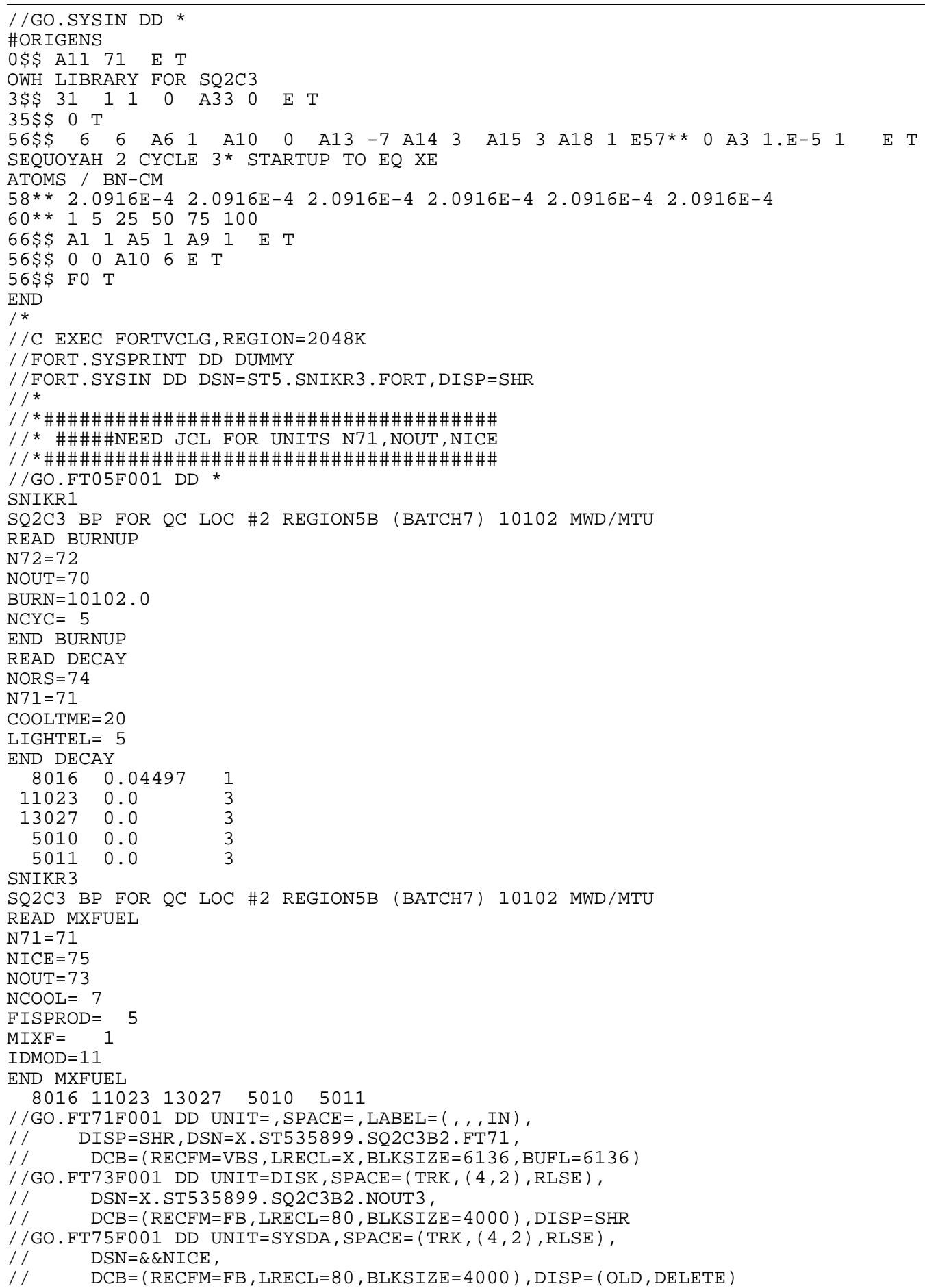


Table E.3. SNIKR/ORIGEN-S input for average cross-section set isotopics

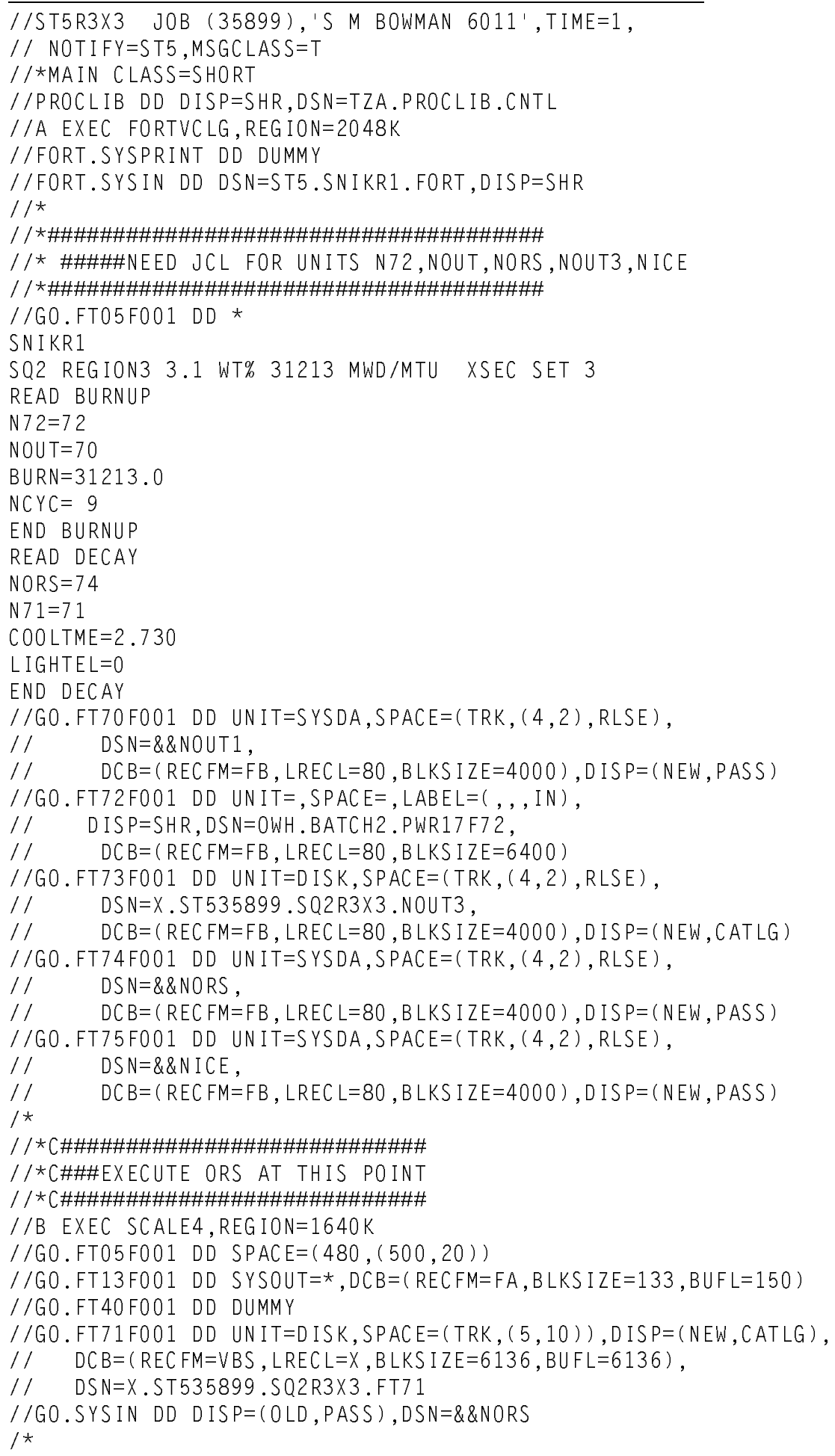


183

Table E.3 (continued)

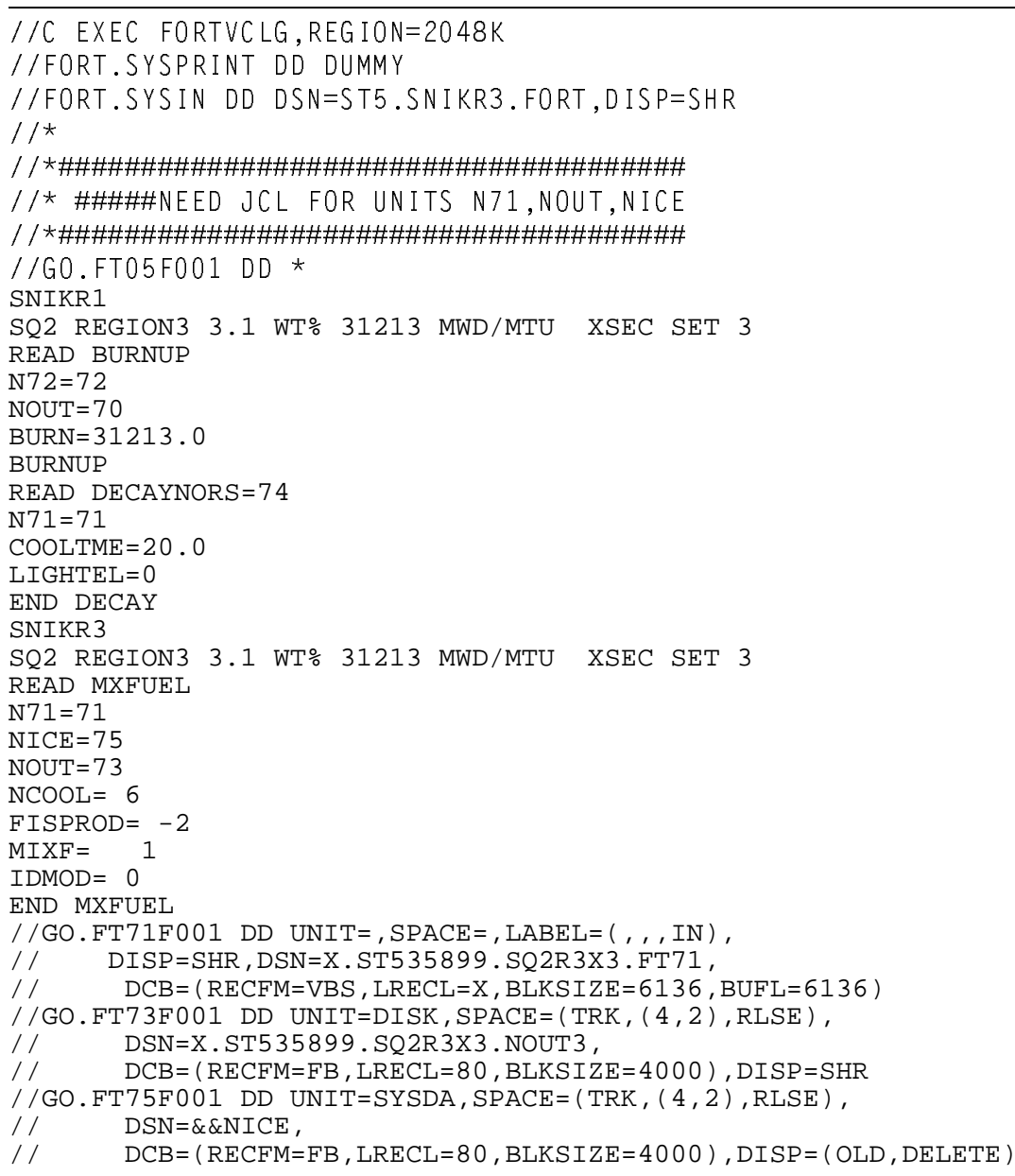


184

Table E.4. CSASN input for cross-section sets with important actinides only

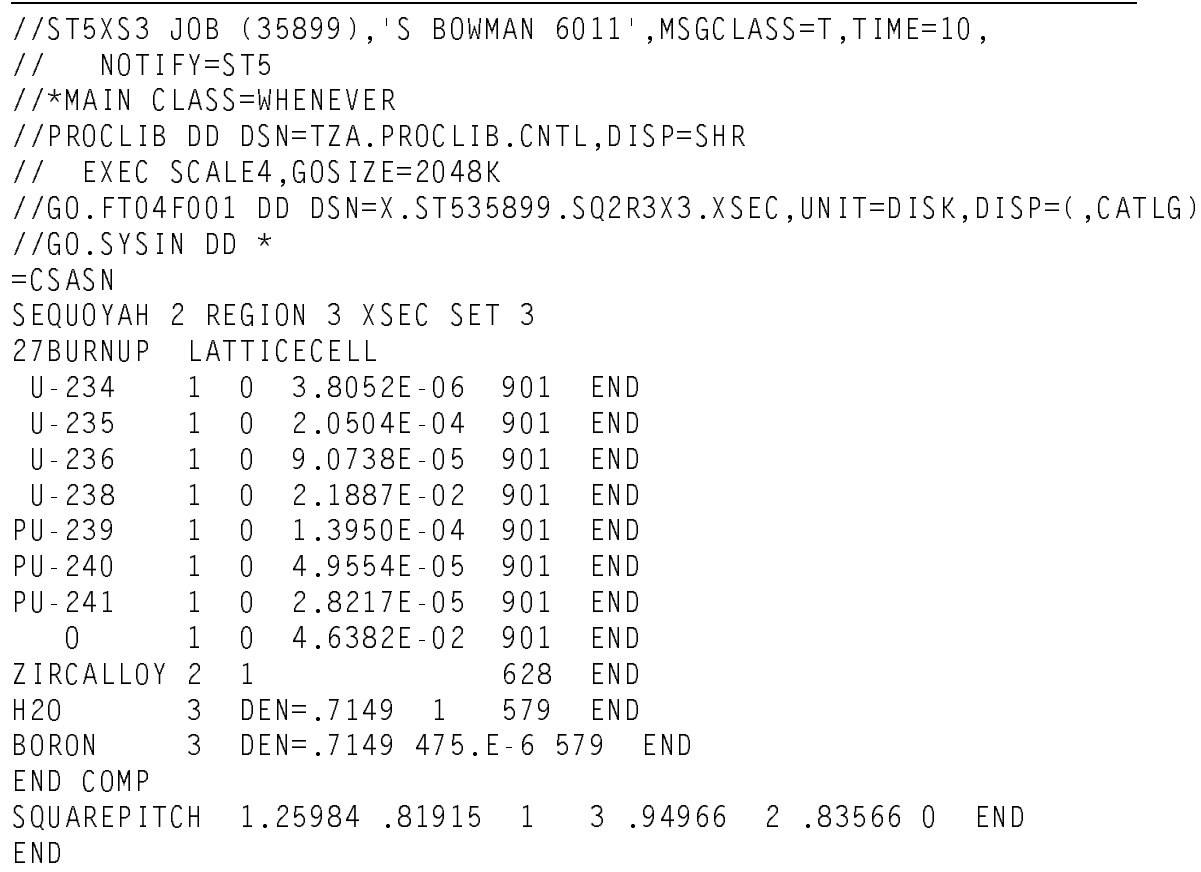


Table E.5. CSASN input for cross-section set 4

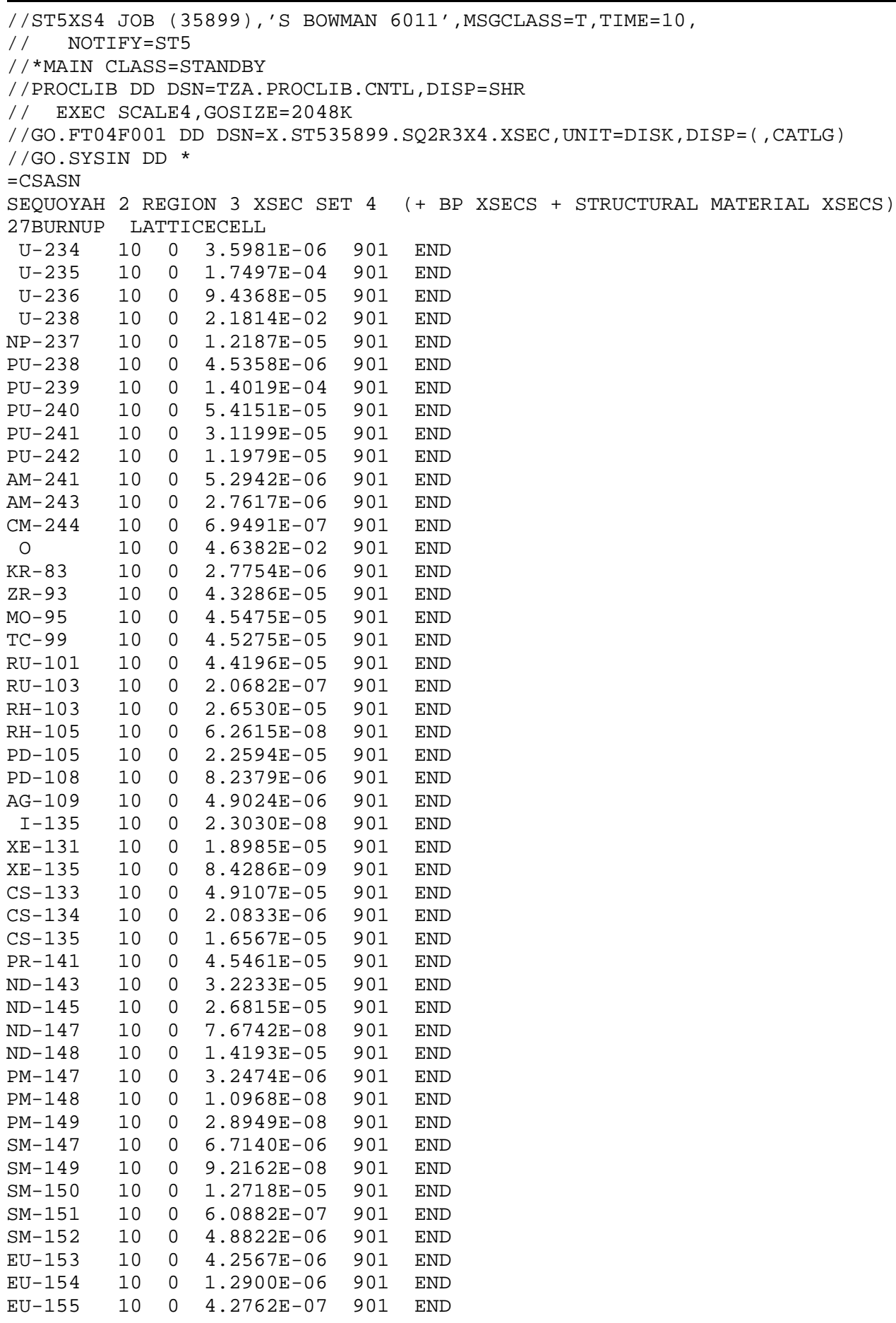


186

\section{Table E.5 (continued)}

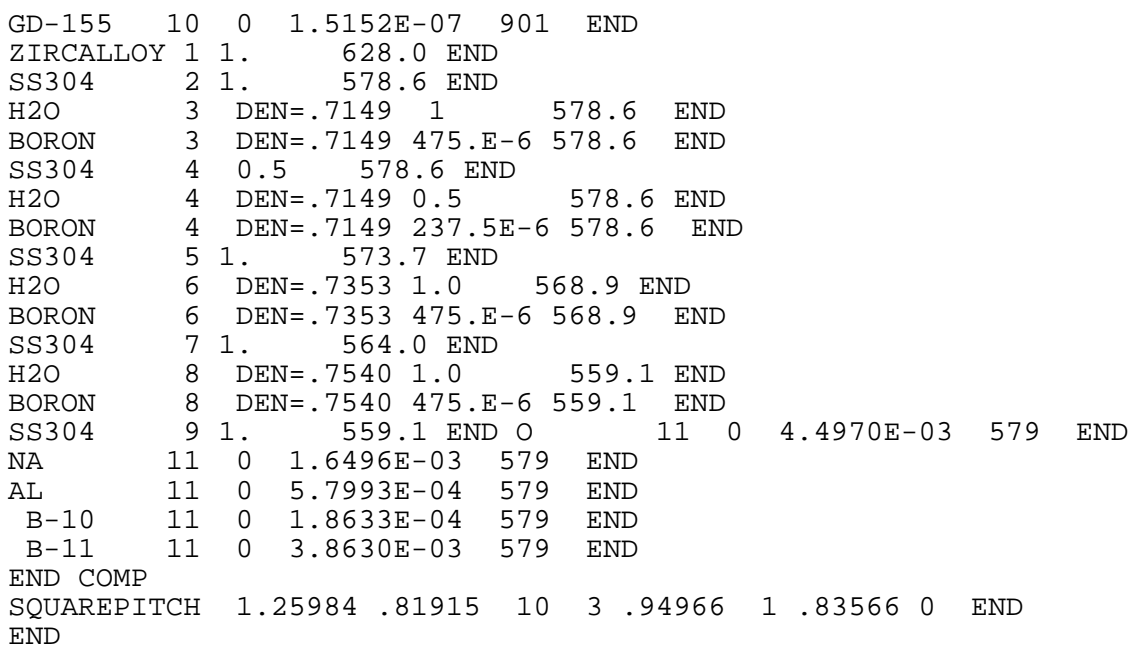


Table E.6. WAX input for cross-section library generation

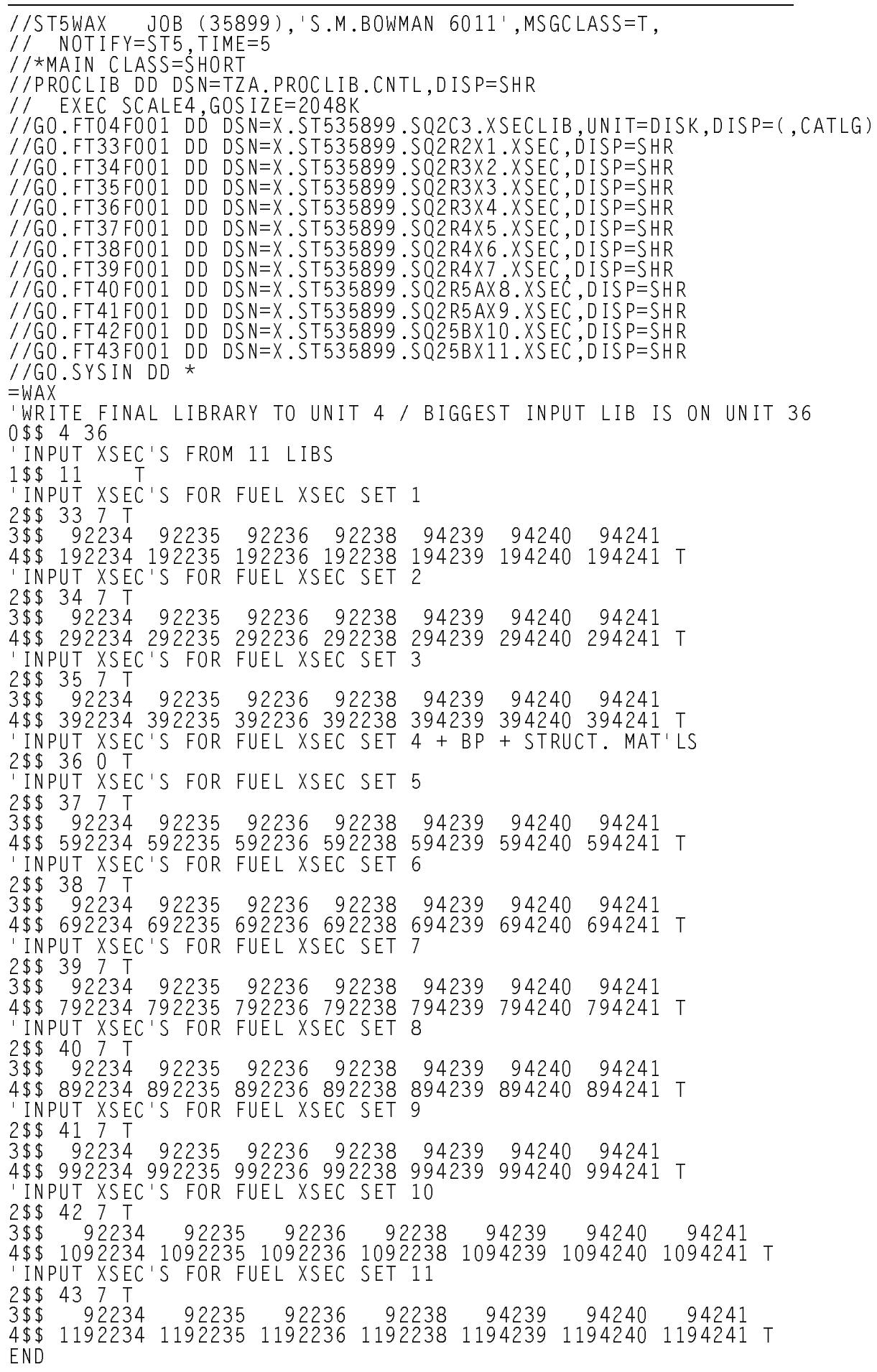


188

Table E.7. XSDRNPM input for assembly P17

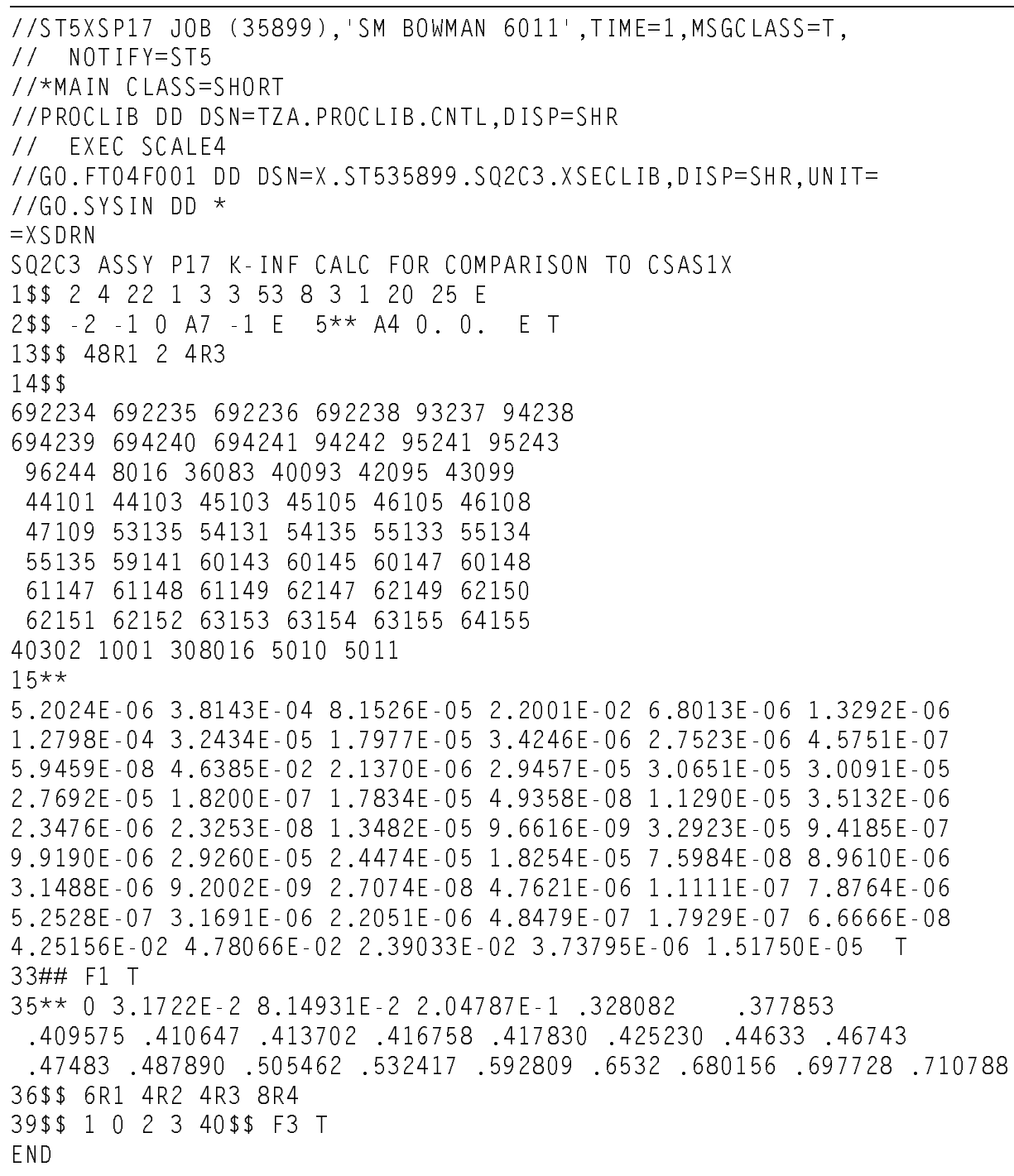


Table E.8. CSAS1X input for assembly P17

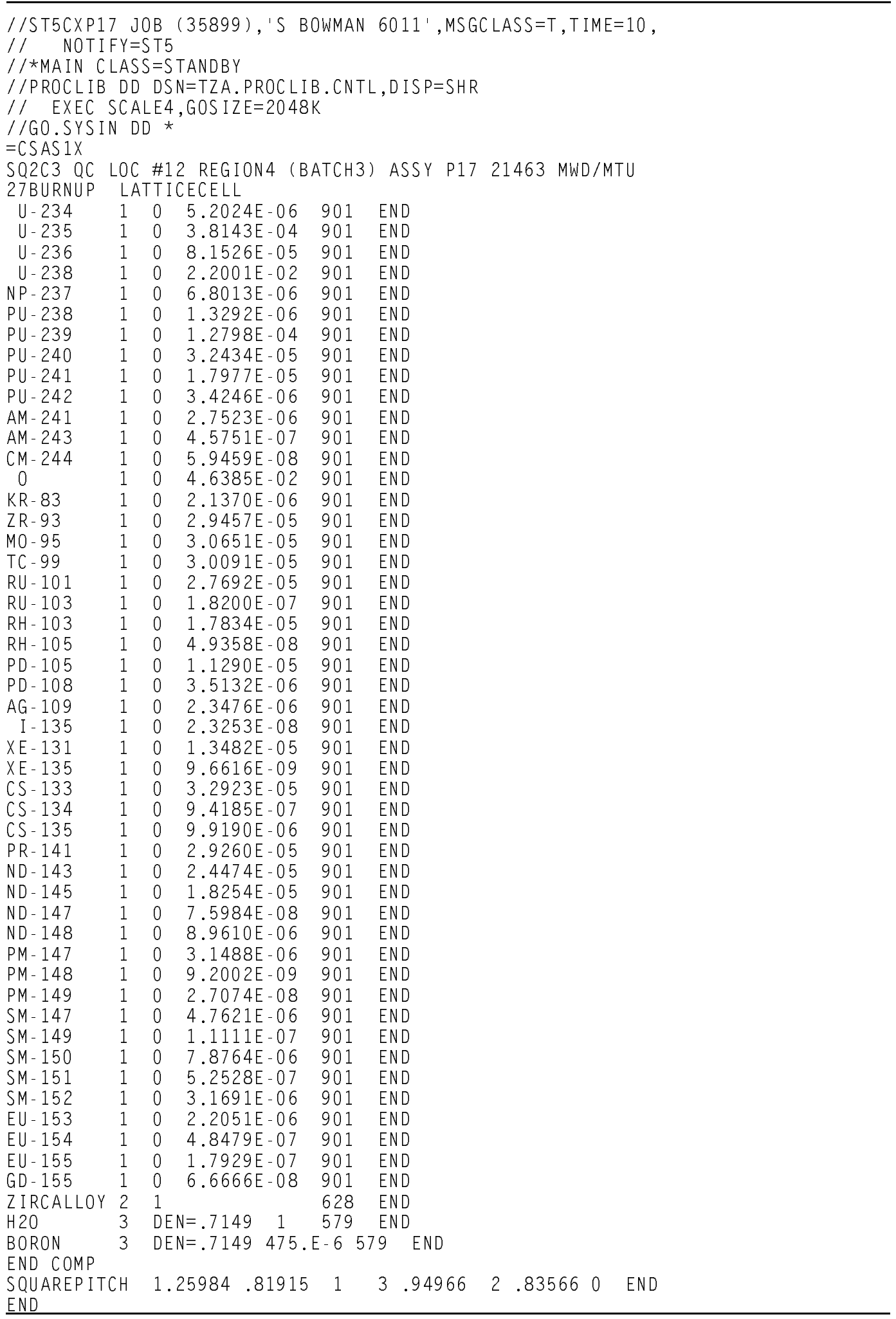


Table E.9. KENO V.a input file for MOC, HFP

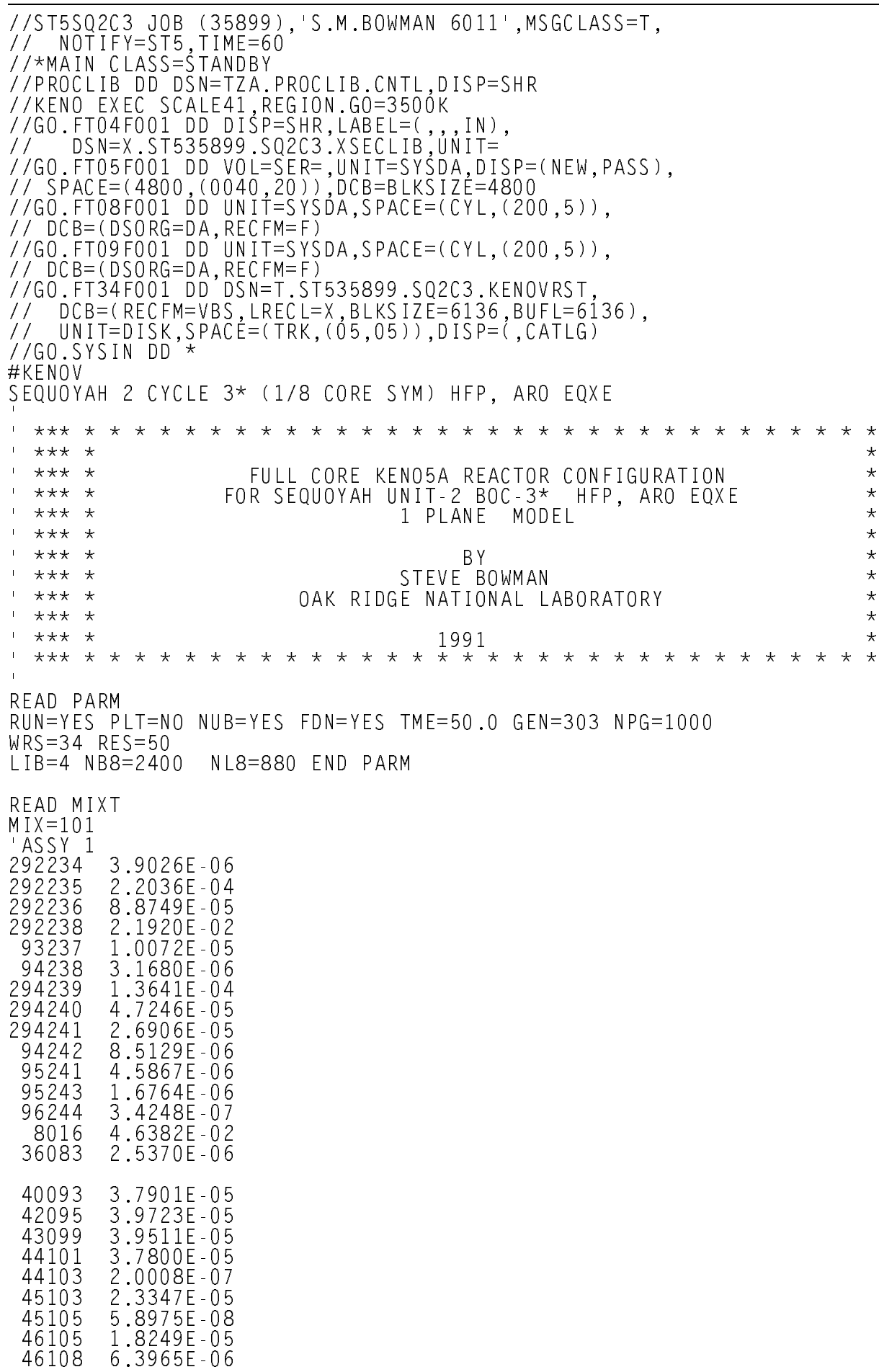


191

Table E.9 (continued)

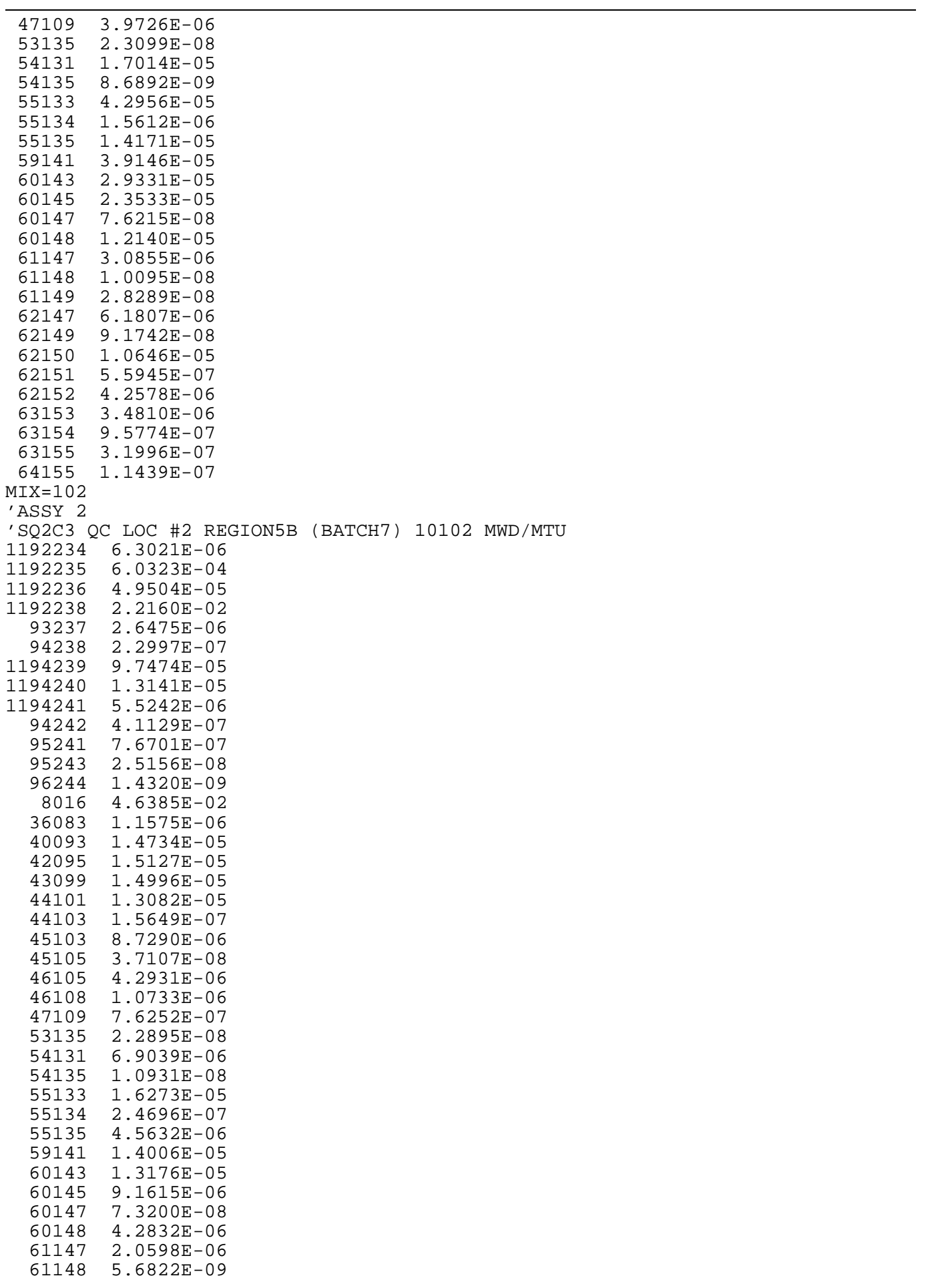


192

Table E.9 (continued)

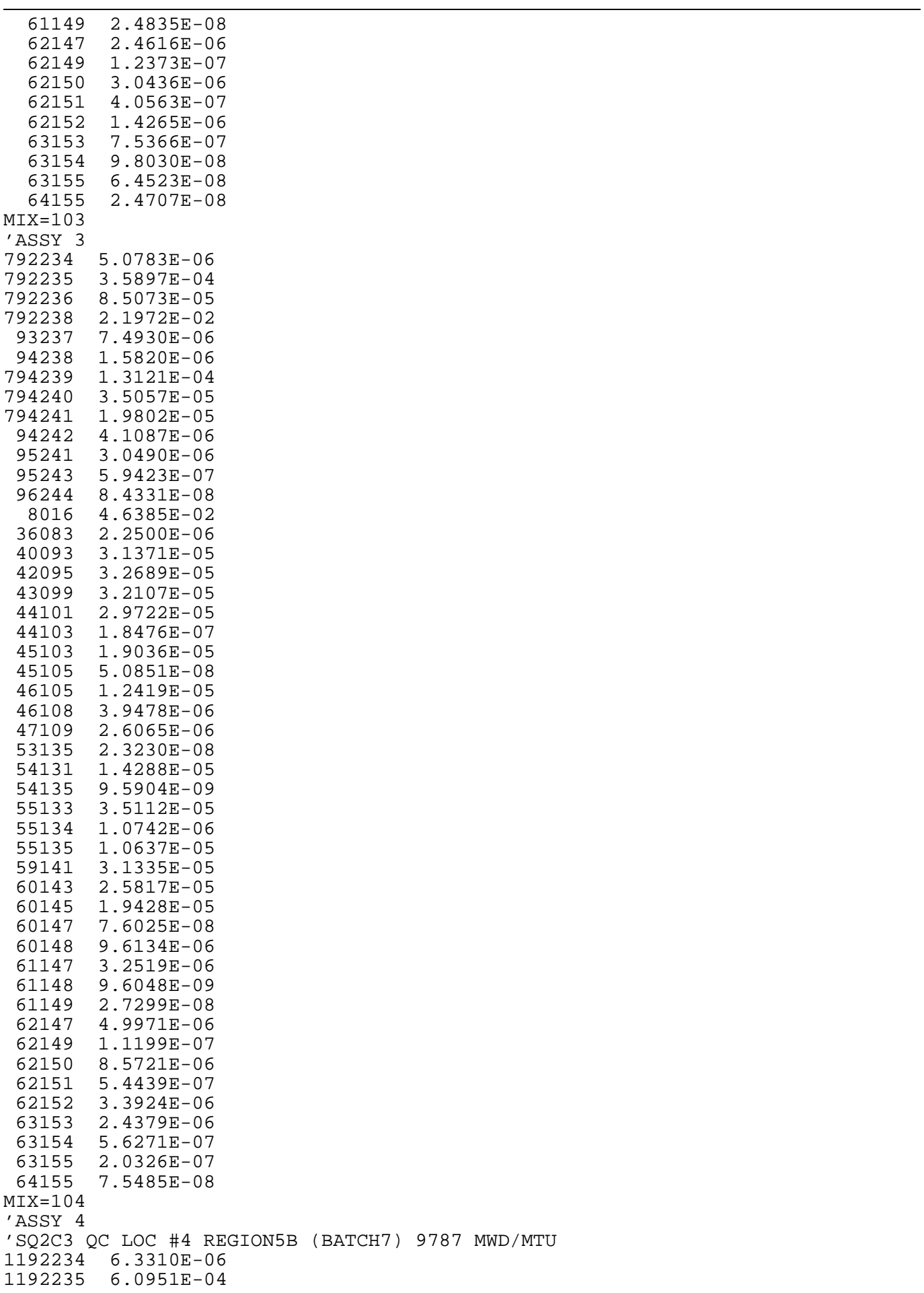


193

Table E.9 (continued)

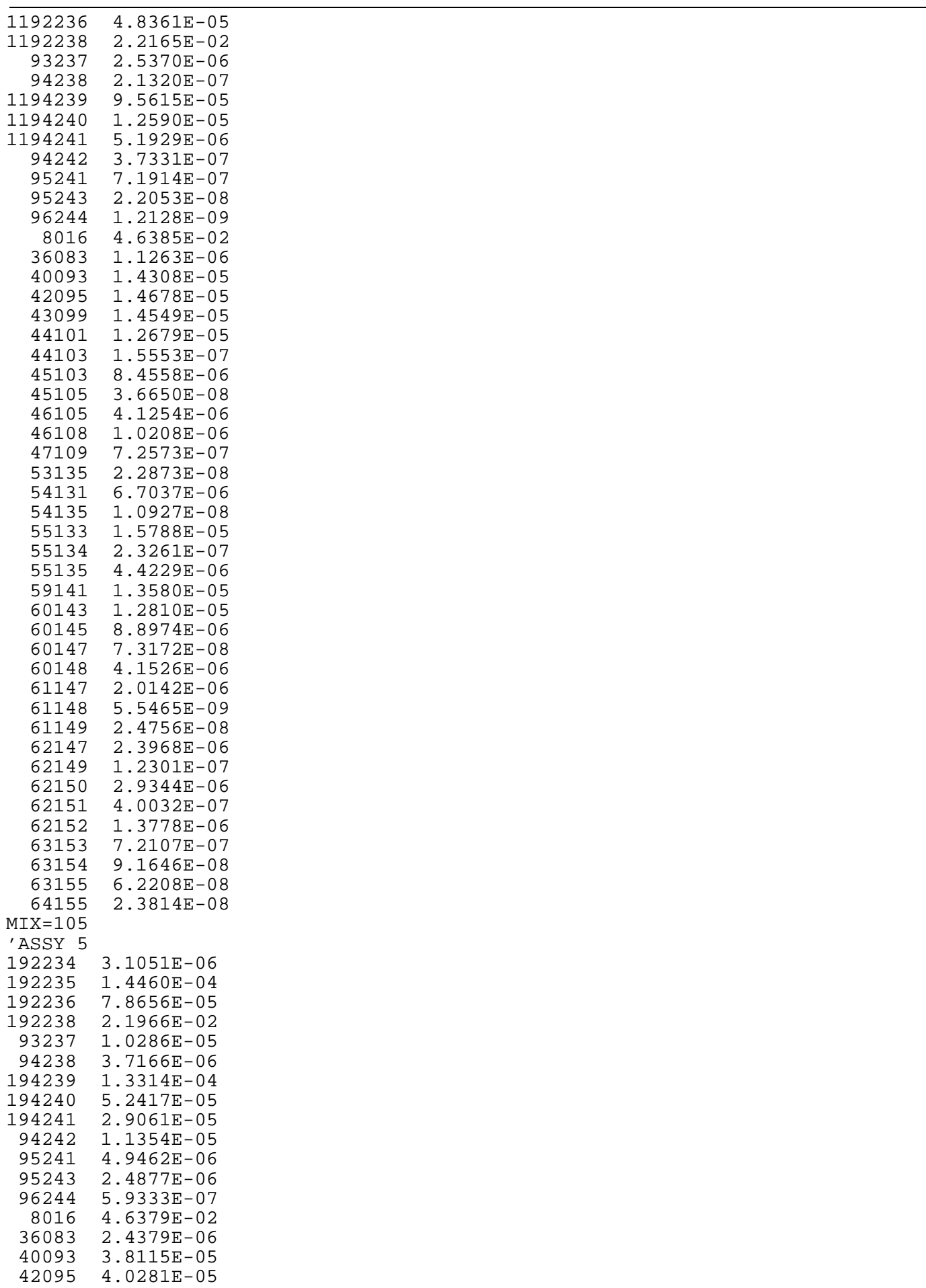


194

Table E.9 (continued)

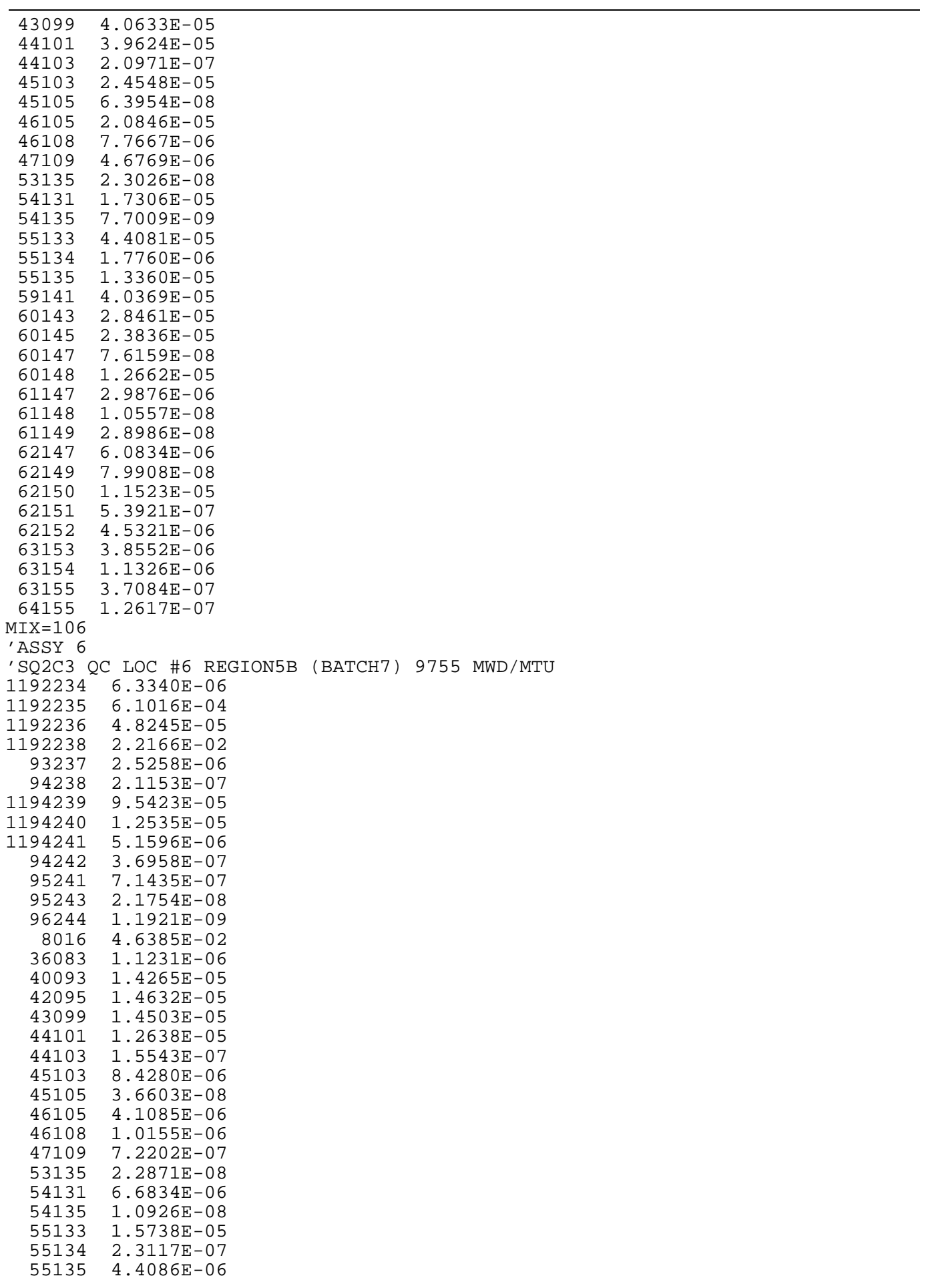


195

Table E.9 (continued)

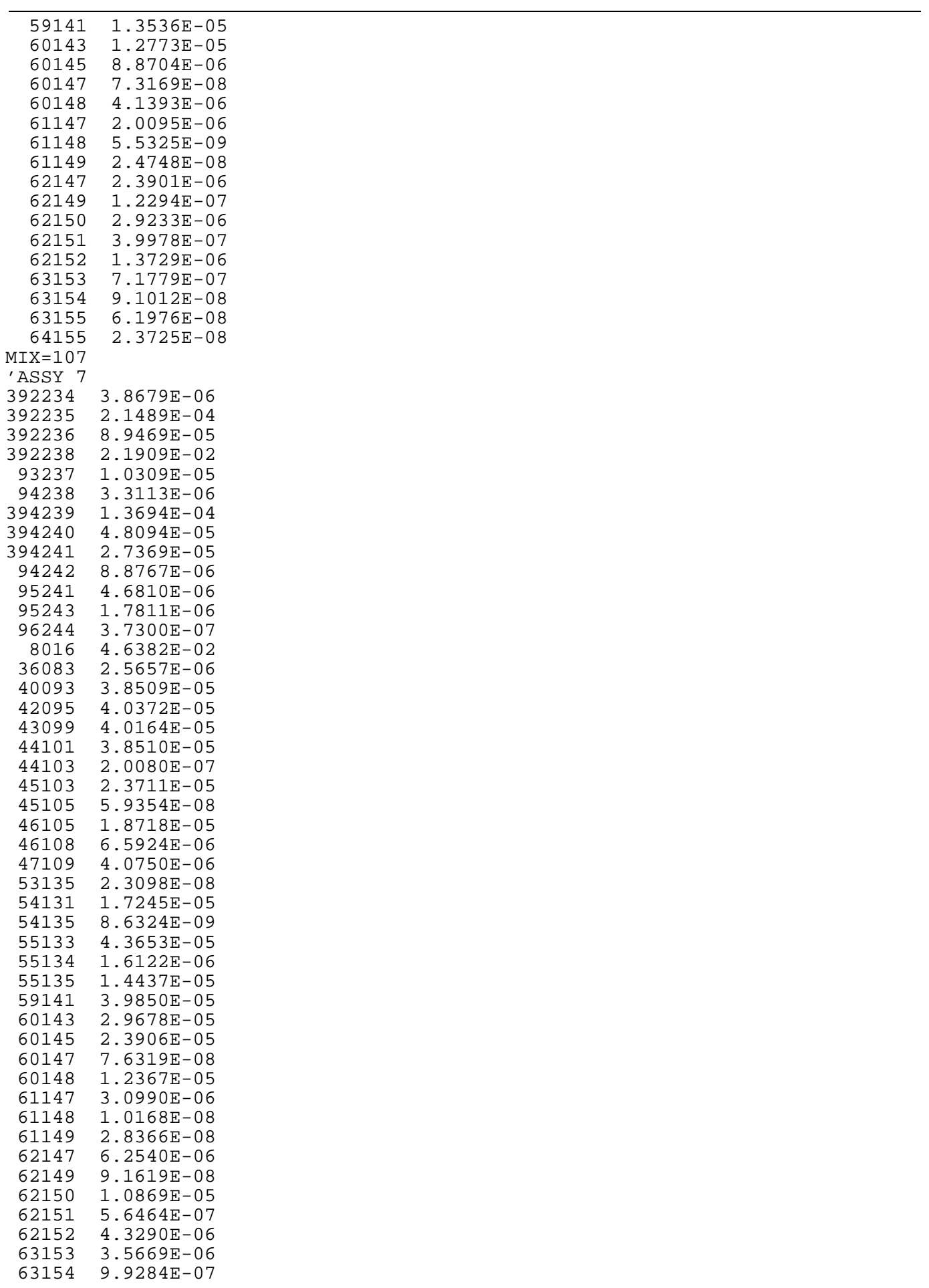


196

Table E.9 (continued)

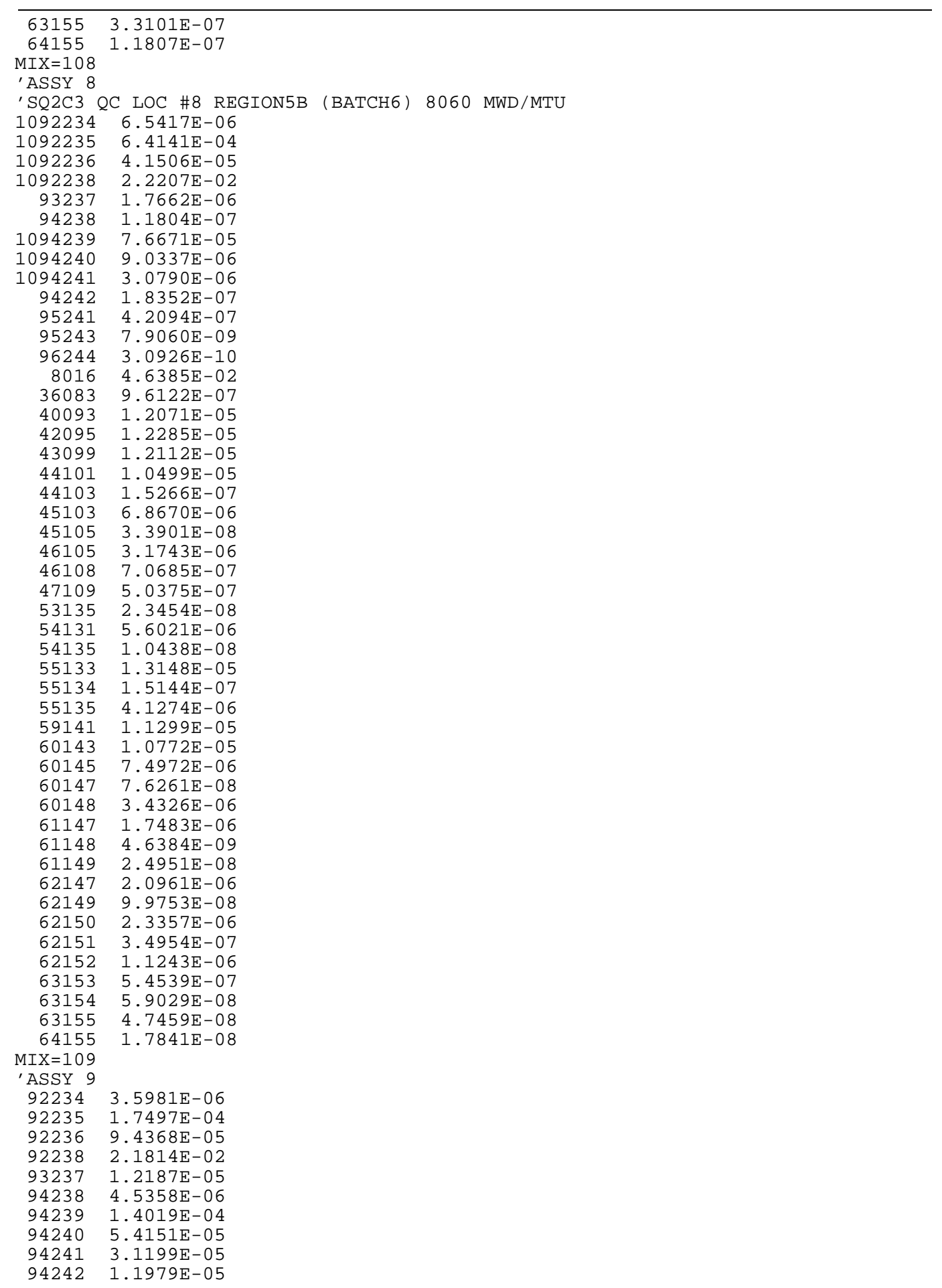


197

Table E.9 (continued)

\begin{tabular}{|c|c|}
\hline 95241 & $5.2942 E-06$ \\
\hline 95243 & $2.7617 E-06$ \\
\hline 96244 & $6.9491 E-07$ \\
\hline 8016 & $4.6382 \mathrm{E}-02$ \\
\hline 36083 & $2.7754 E-06$ \\
\hline 40093 & $4.3286 E-05$ \\
\hline 42095 & $4.5475 \mathrm{E}-05$ \\
\hline 43099 & $4.5275 \mathrm{E}-05$ \\
\hline 44101 & $4.4196 \mathrm{E}-05$ \\
\hline 44103 & $2.0682 \mathrm{E}-07$ \\
\hline 45103 & $2.6530 \mathrm{E}-05$ \\
\hline 45105 & $6.2615 E-08$ \\
\hline 46105 & $2.2594 \mathrm{E}-05$ \\
\hline 46108 & $8.2379 E-06$ \\
\hline 47109 & $4.9024 \mathrm{E}-06$ \\
\hline 53135 & $2.3030 E-08$ \\
\hline 54131 & $1.8985 E-05$ \\
\hline 54135 & $8.4286 \mathrm{E}-09$ \\
\hline 55133 & $4.9107 \mathrm{E}-05$ \\
\hline 55134 & $2.0833 E-06$ \\
\hline 55135 & $1.6567 \mathrm{E}-05$ \\
\hline 59141 & $4.5461 E-05$ \\
\hline 60143 & $3.2233 E-05$ \\
\hline 60145 & $2.6815 \mathrm{E}-05$ \\
\hline 60147 & $7.6742 \mathrm{E}-08$ \\
\hline 60148 & 1. $4193 \mathrm{E}-05$ \\
\hline 61147 & $3.2474 E-06$ \\
\hline 61148 & $1.0968 \mathrm{E}-08$ \\
\hline 61149 & $2.8949 E-08$ \\
\hline 62147 & $6.7140 \mathrm{E}-06$ \\
\hline 62149 & $9.2162 \mathrm{E}-08$ \\
\hline 62150 & $1.2718 \mathrm{E}-05$ \\
\hline 62151 & $6.0882 E-07$ \\
\hline 62152 & $4.8822 \mathrm{E}-06$ \\
\hline 63153 & $4.2567 \mathrm{E}-06$ \\
\hline 63154 & $1.2900 E-06$ \\
\hline 63155 & $4.2762 \mathrm{E}-07$ \\
\hline 64155 & $1.5152 \mathrm{E}-07$ \\
\hline \multicolumn{2}{|c|}{$\mathrm{MIX}=110$} \\
\hline \multicolumn{2}{|c|}{ 'ASSY 10} \\
\hline 792234 & $5.0976 \mathrm{E}-06$ \\
\hline 792235 & $3.6245 E-04$ \\
\hline 792236 & $8.4530 \mathrm{E}-05$ \\
\hline 792238 & $2.1976 \mathrm{E}-02$ \\
\hline 93237 & $7.3833 E-06$ \\
\hline 94238 & $1.5404 E-06$ \\
\hline 794239 & $1.3073 E-04$ \\
\hline 794240 & $3.4648 E-05$ \\
\hline 794241 & $1.9518 E-05$ \\
\hline 94242 & $3.9969 \mathrm{E}-06$ \\
\hline 95241 & $3.0025 E-06$ \\
\hline 95243 & $5.7112 \mathrm{E}-07$ \\
\hline 96244 & $7.9966 \mathrm{E}-08$ \\
\hline 8016 & $4.6385 \mathrm{E}-02$ \\
\hline 36083 & $2.2326 E-06$ \\
\hline 40093 & $3.1071 \mathrm{E}-05$ \\
\hline 42095 & $3.2370 E-05$ \\
\hline 43099 & $3.1792 E-05$ \\
\hline 44101 & $2.9402 E-05$ \\
\hline 44103 & $1.8433 E-07$ \\
\hline 45103 & $1.8849 \mathrm{E}-05$ \\
\hline 45105 & $5.0620 E-08$ \\
\hline 46105 & $1.2240 \mathrm{E}-05$ \\
\hline 46108 & $3.8781 E-06$ \\
\hline 47109 & $2.5654 \mathrm{E}-06$ \\
\hline
\end{tabular}


198

Table E.9 (continued)

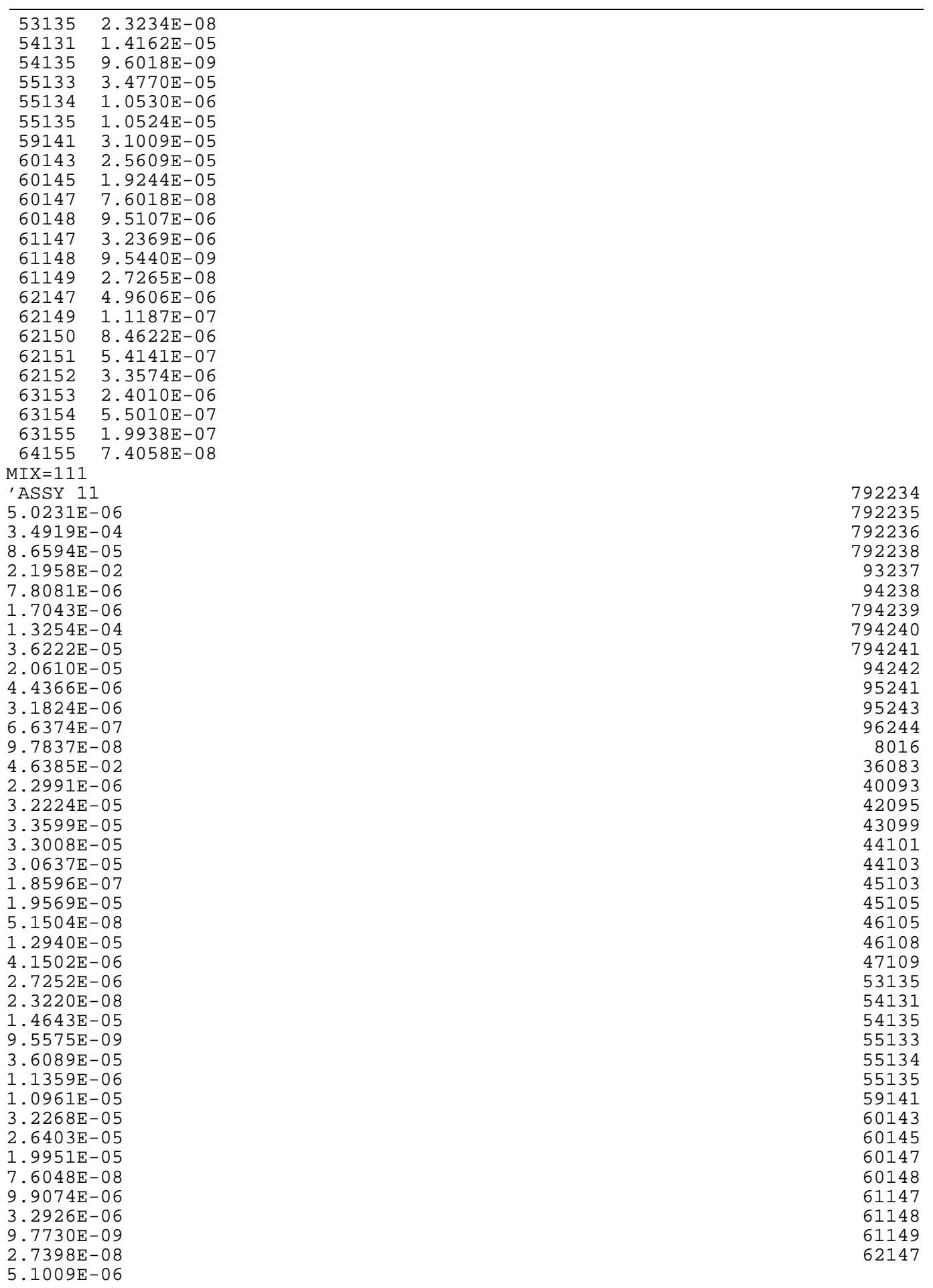


199

Table E.9 (continued)

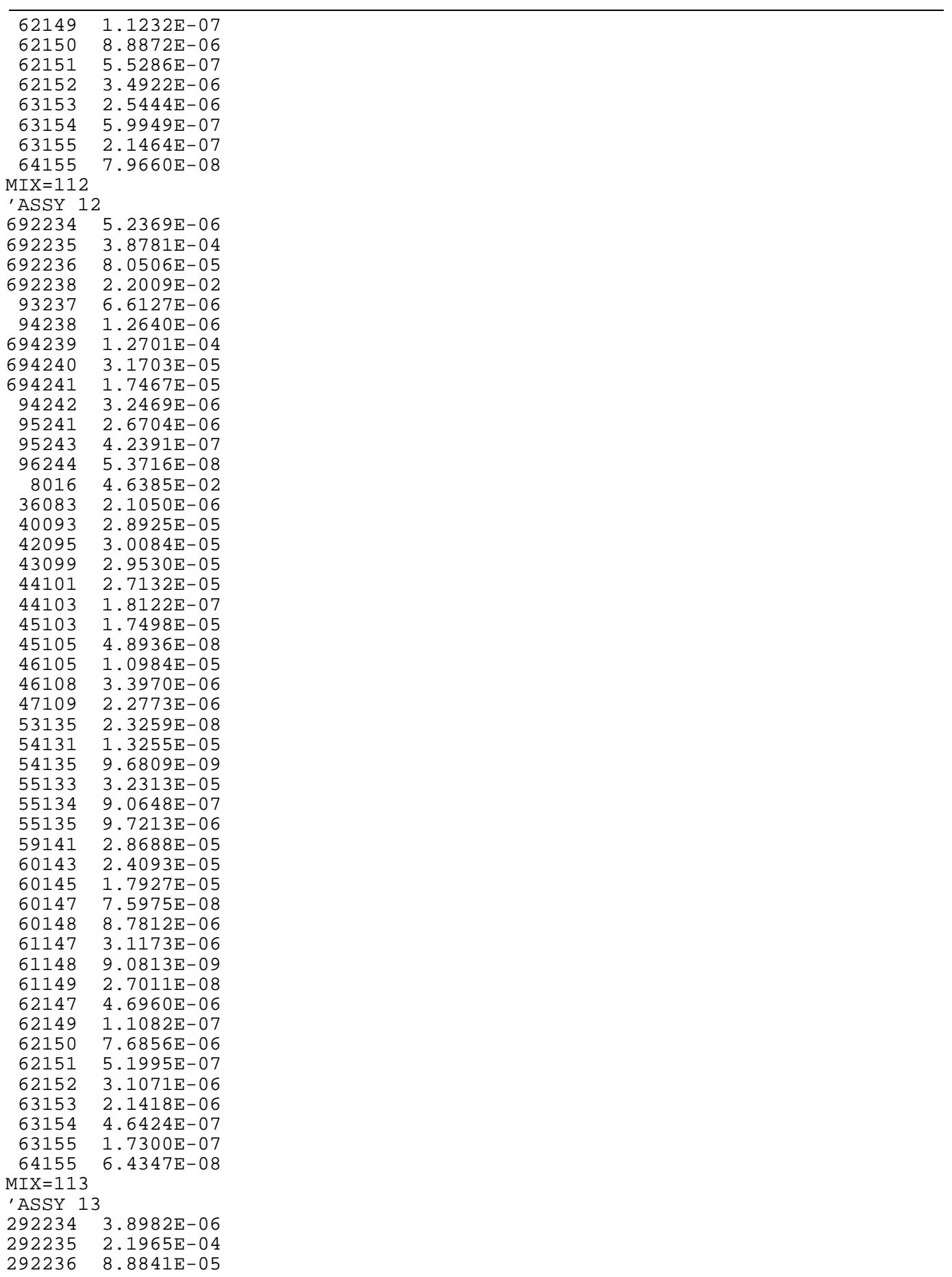


Table E.9 (continued)

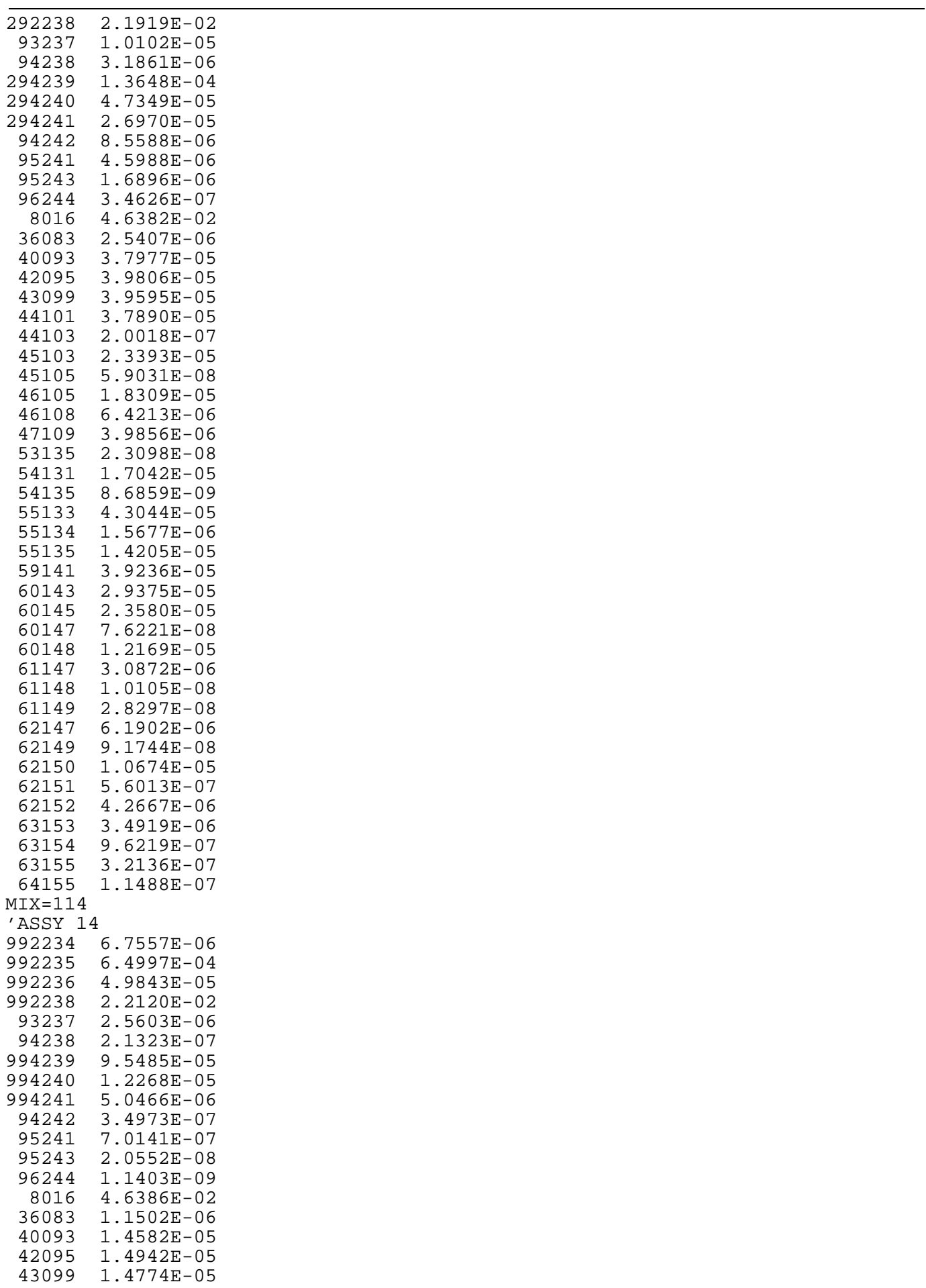


Table E.9 (continued)

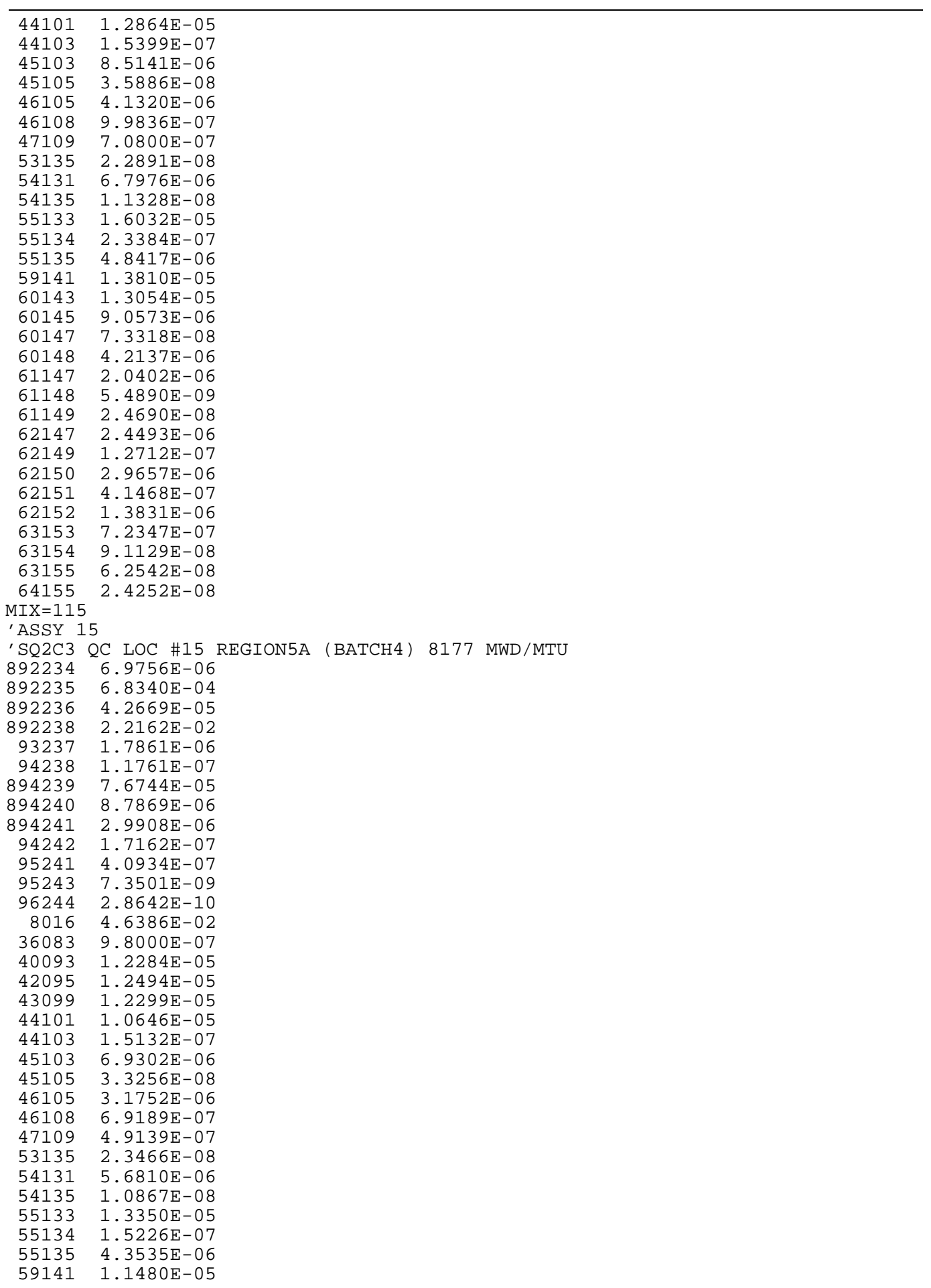


Table E.9 (continued)

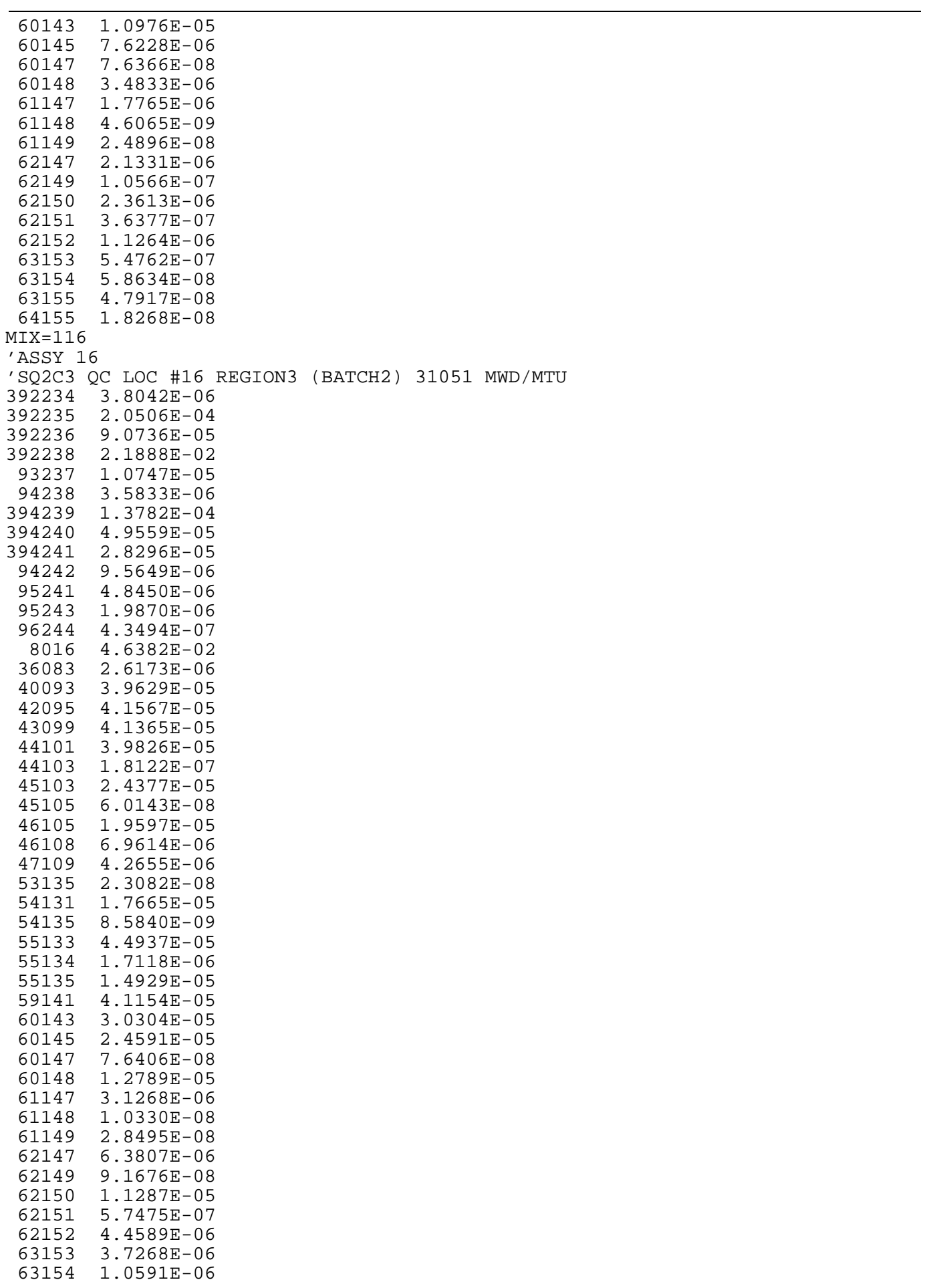


Table E.9 (continued)

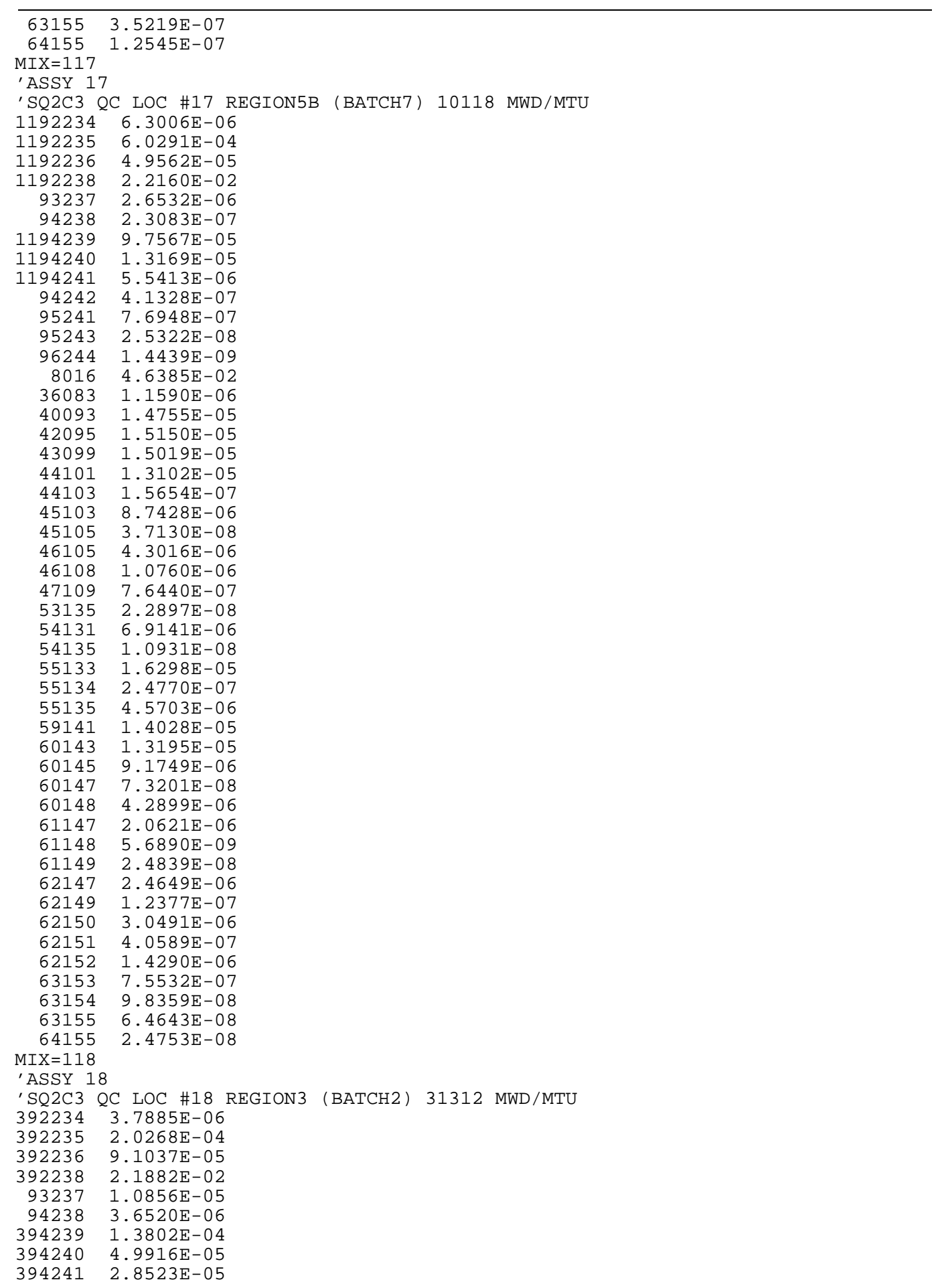


Table E.9 (continued)

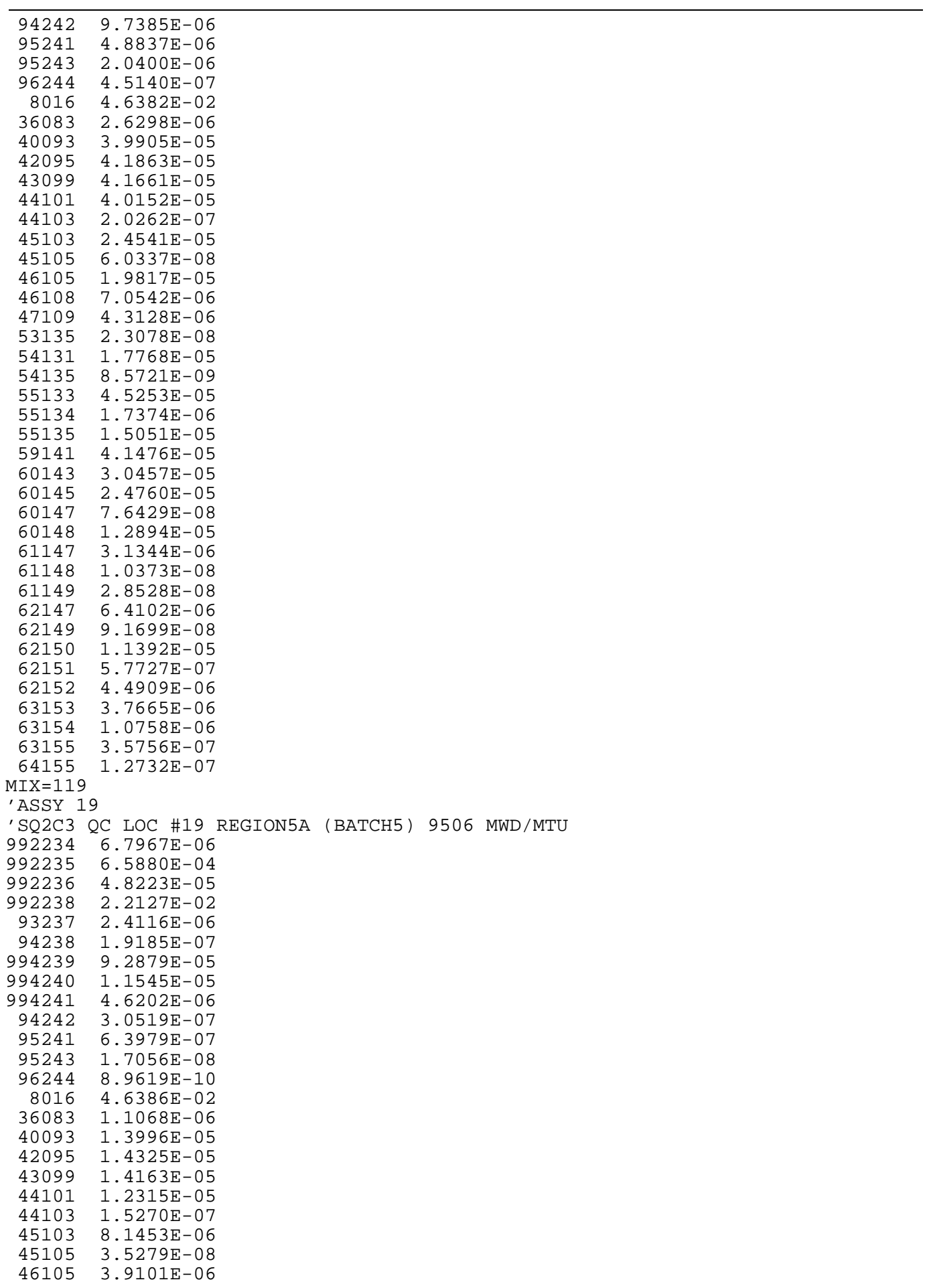


Table E.9 (continued)

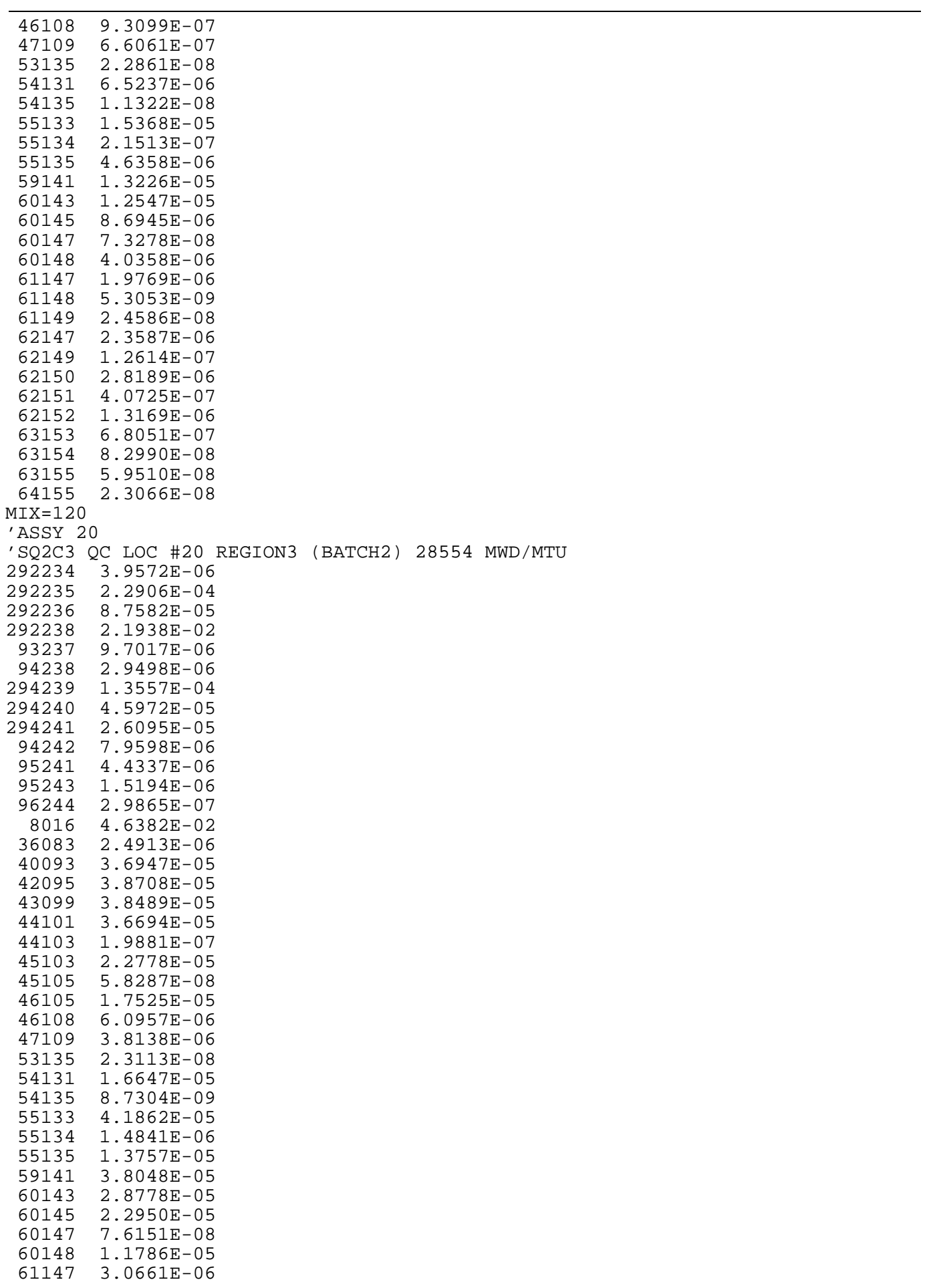


Table E.9 (continued)

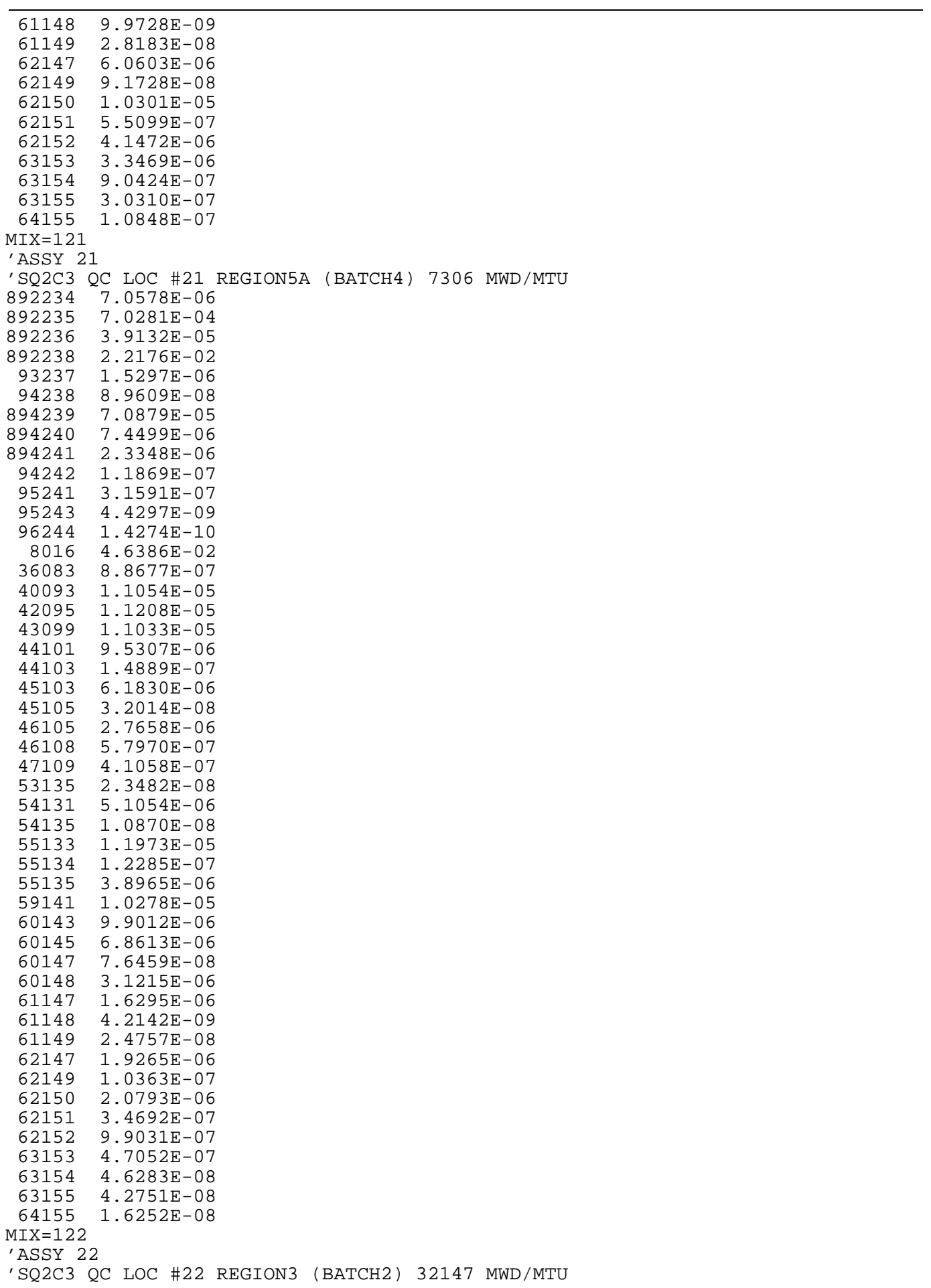


Table E.9 (continued)

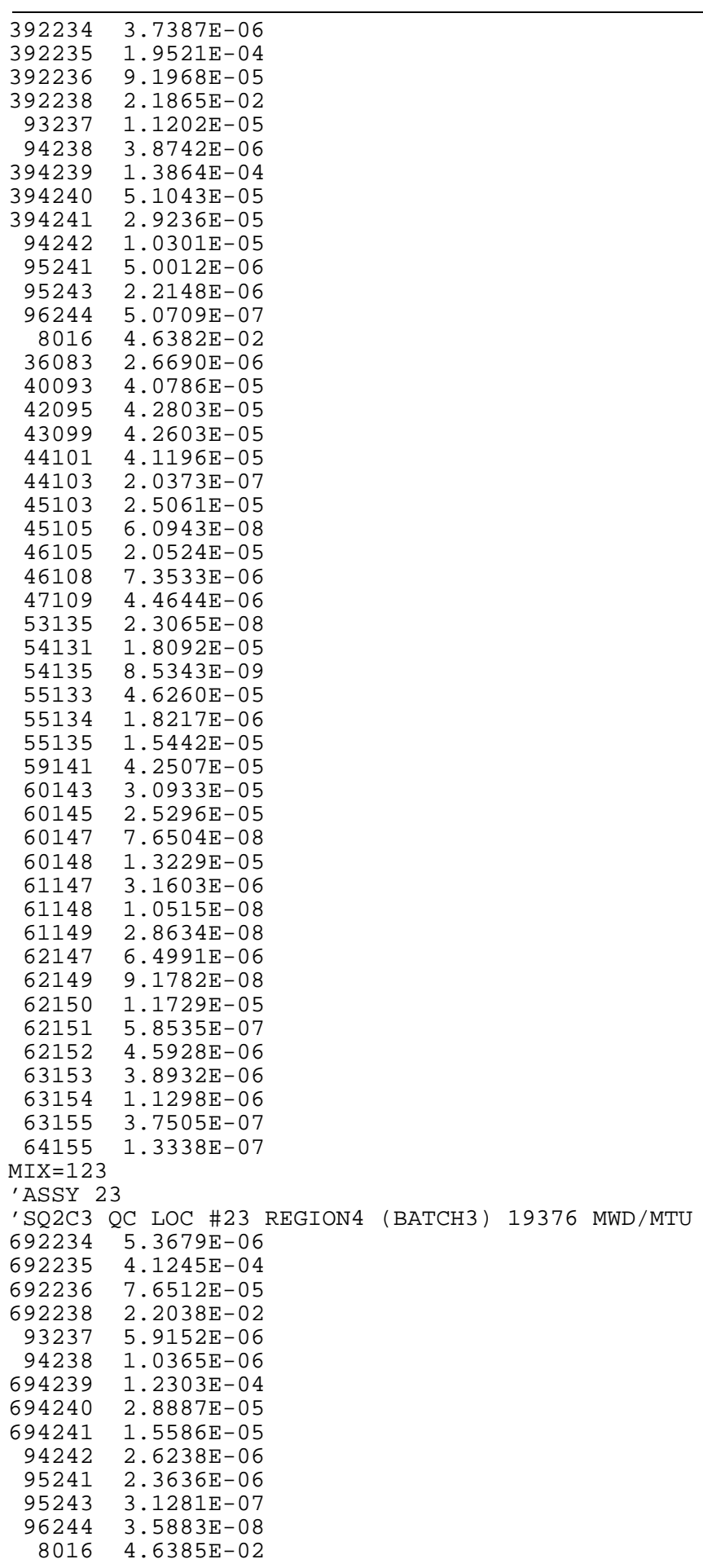


Table E.9 (continued)

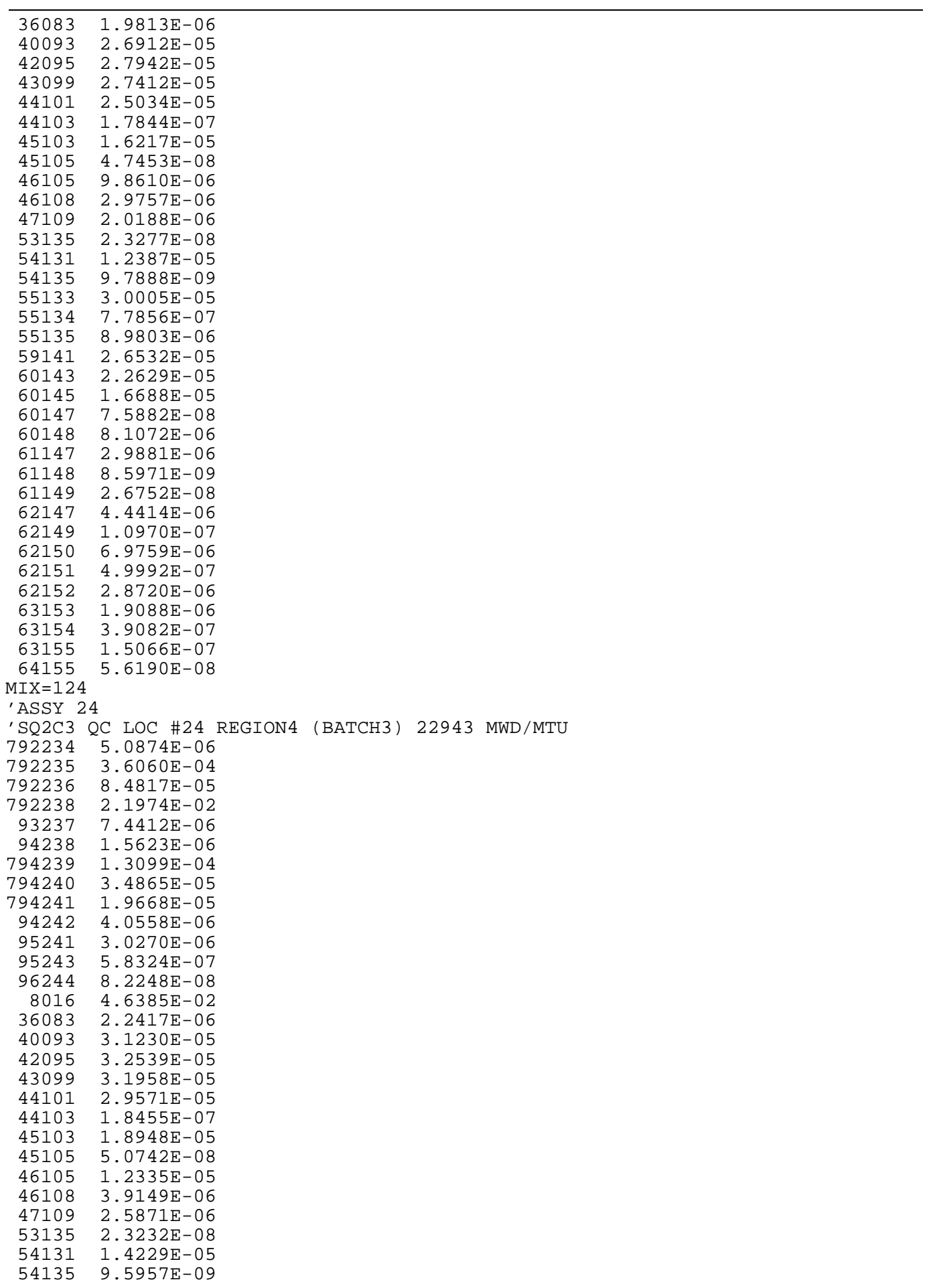


Table E.9 (continued)

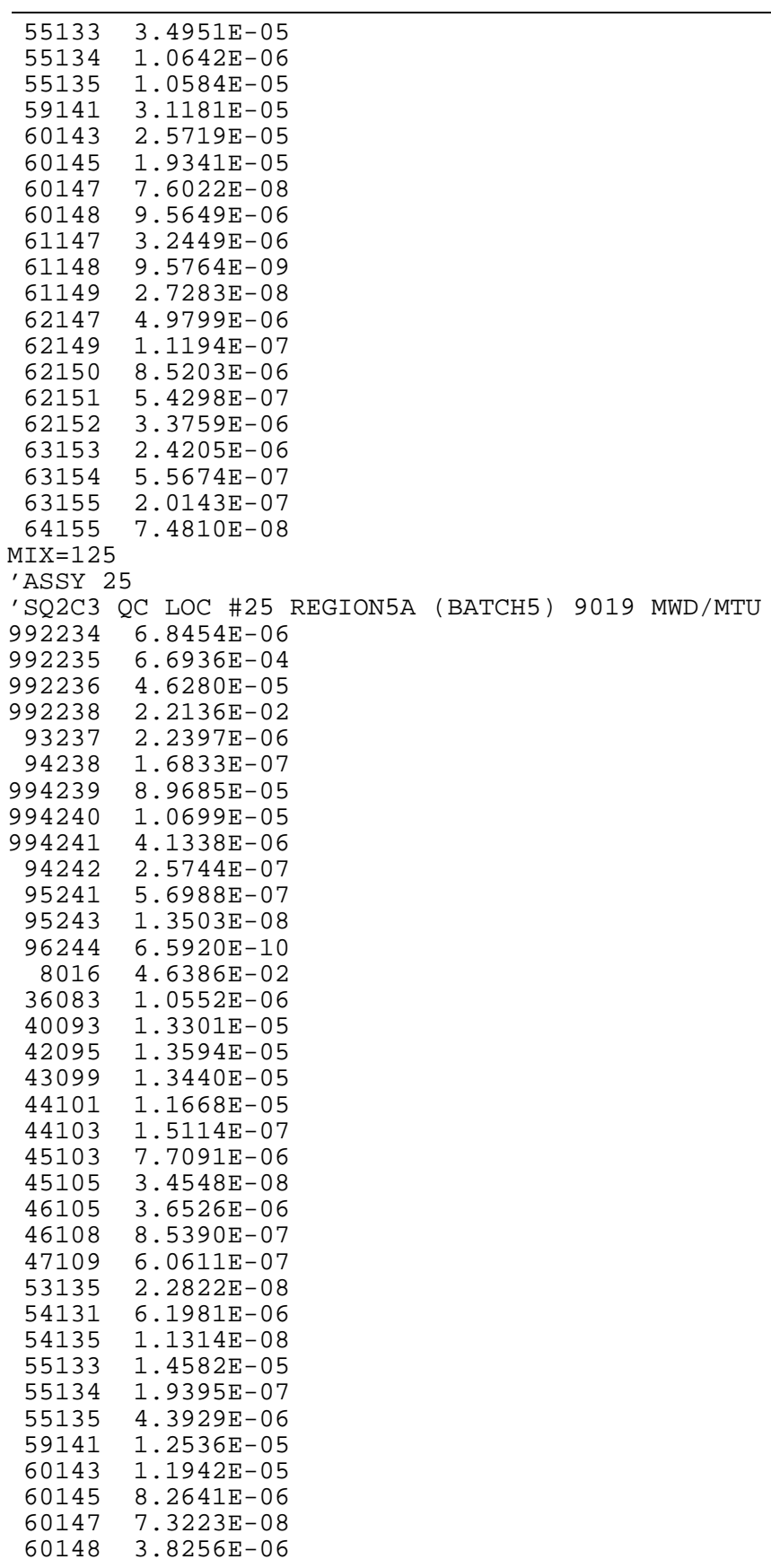


Table E.9 (continued)

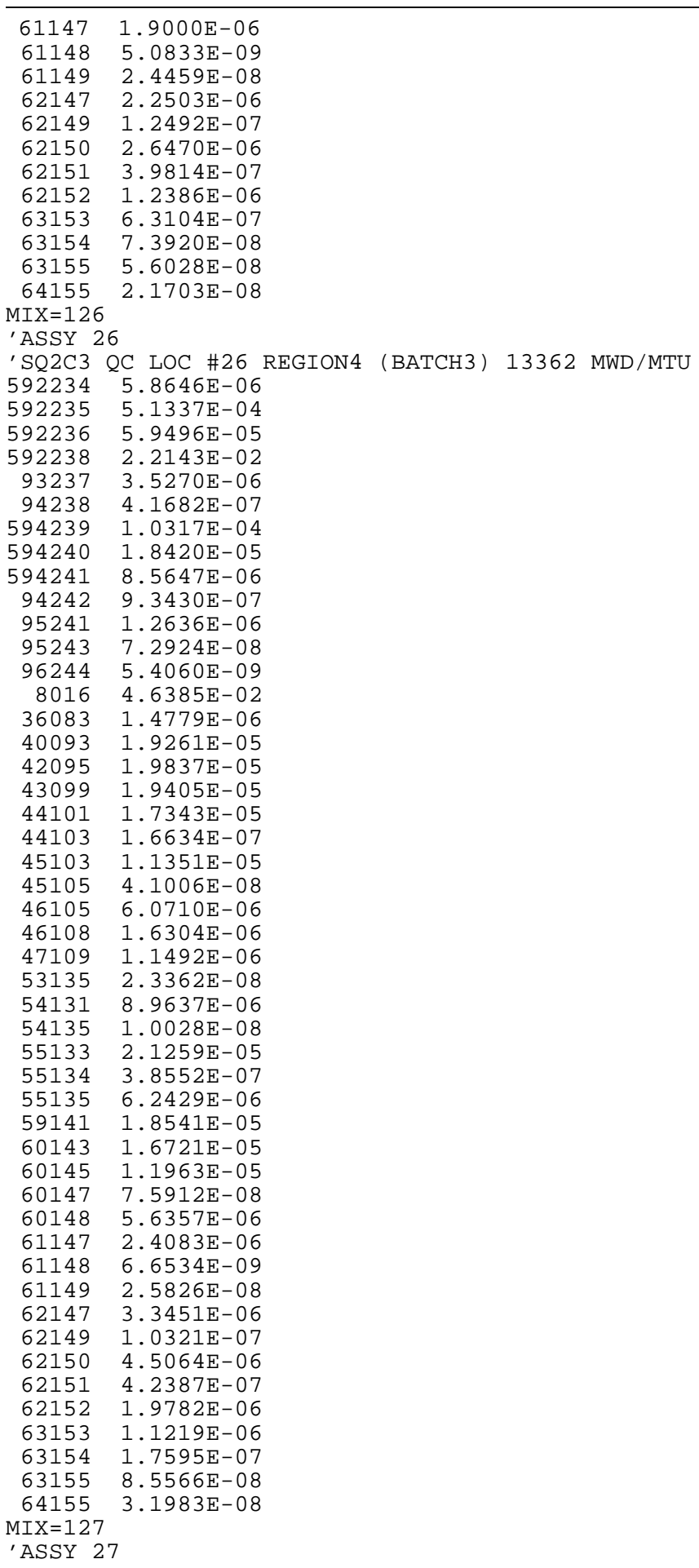


Table E.9 (continued)

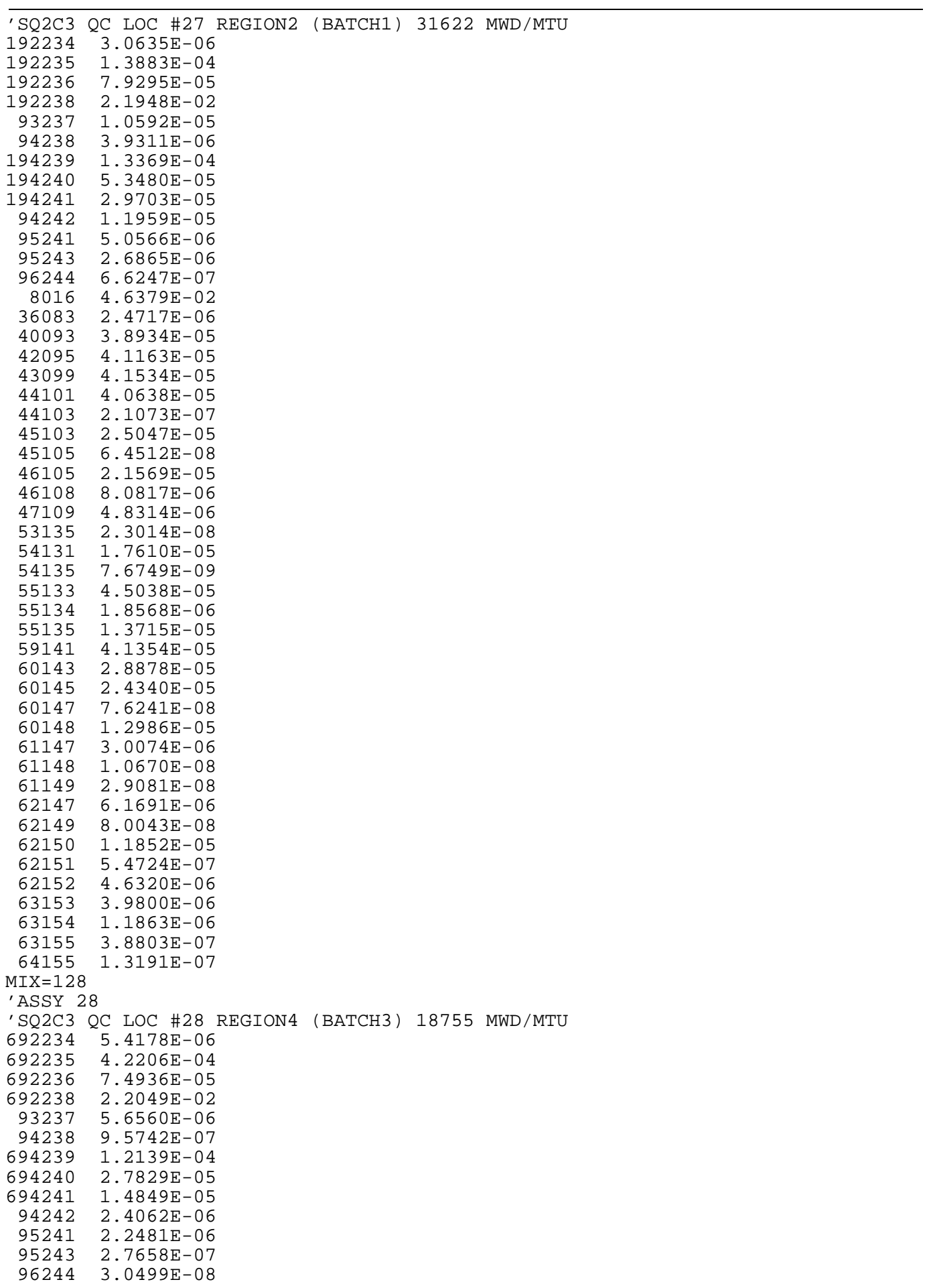


Table E.9 (continued)

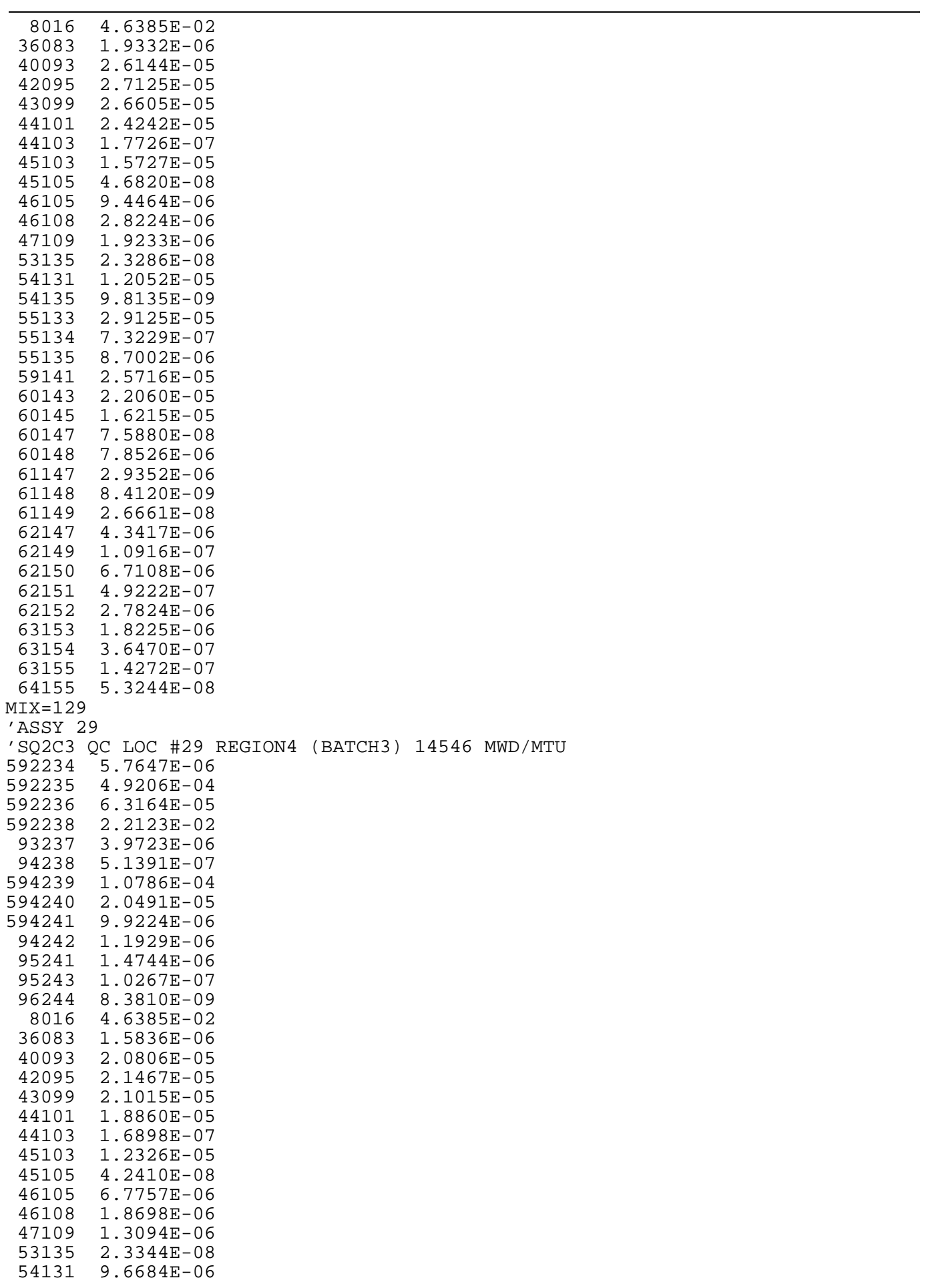


Table E.9 (continued)

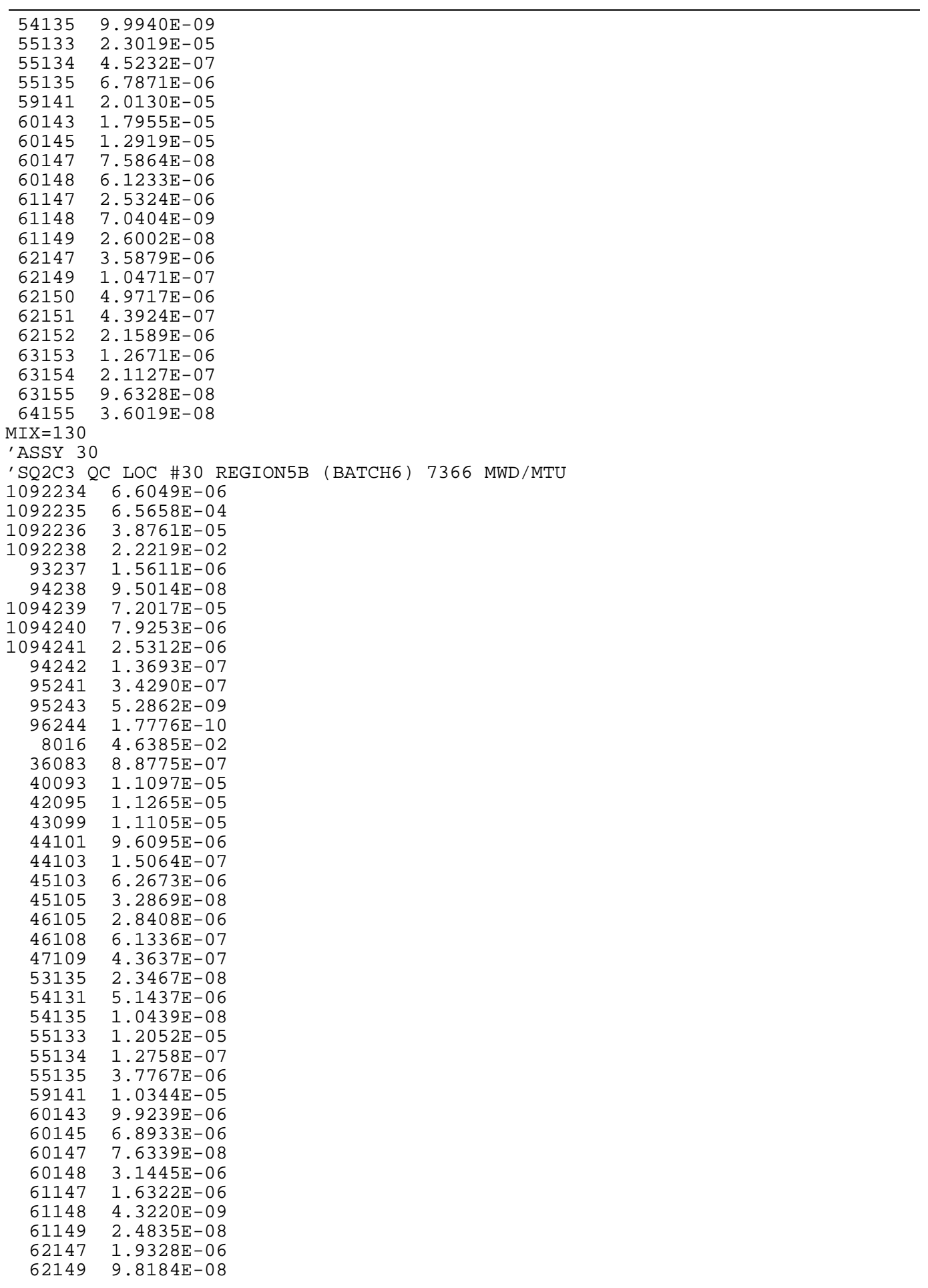


Table E.9 (continued)

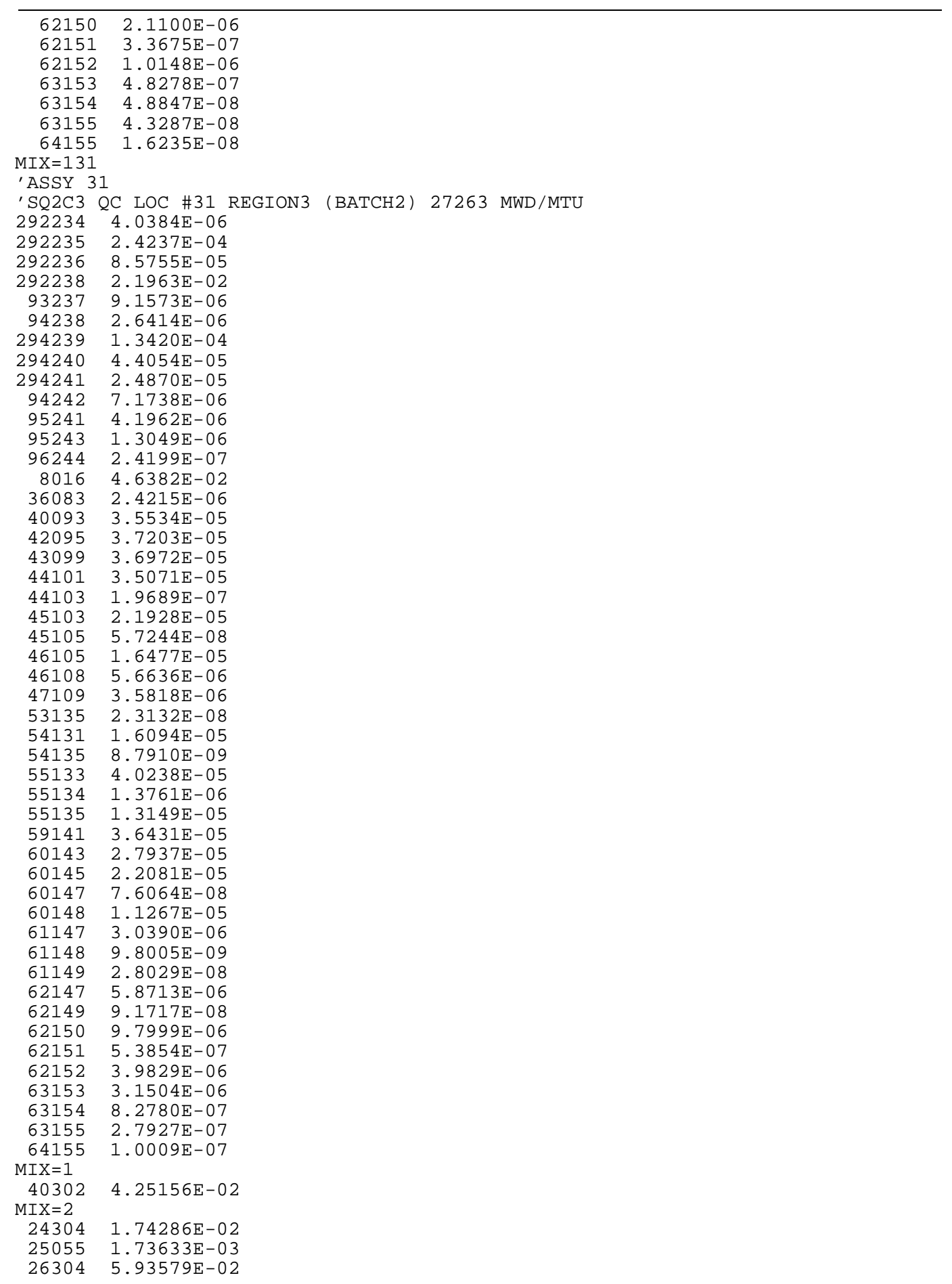


Table E.9 (continued)

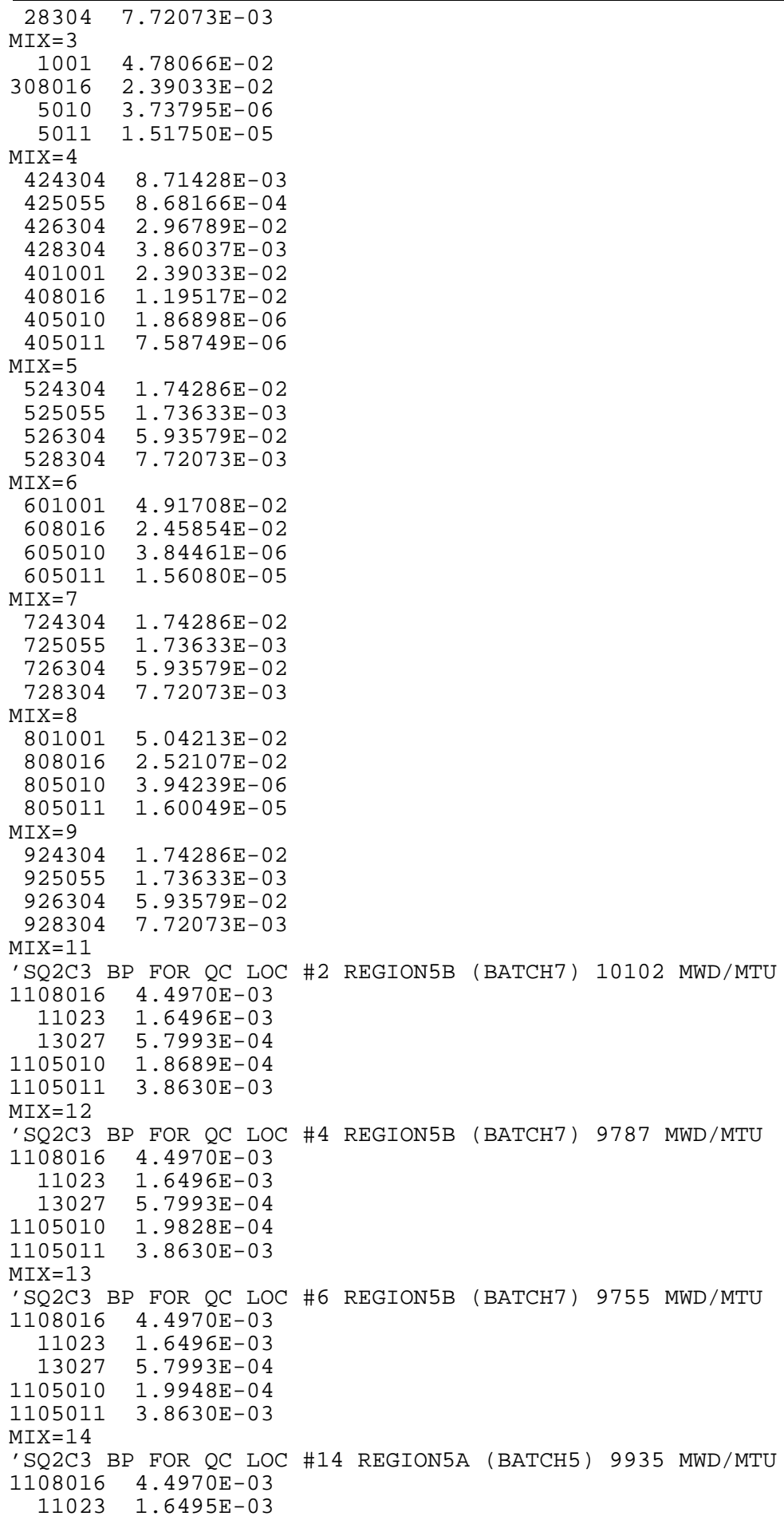




\section{Table E.9 (continued)}

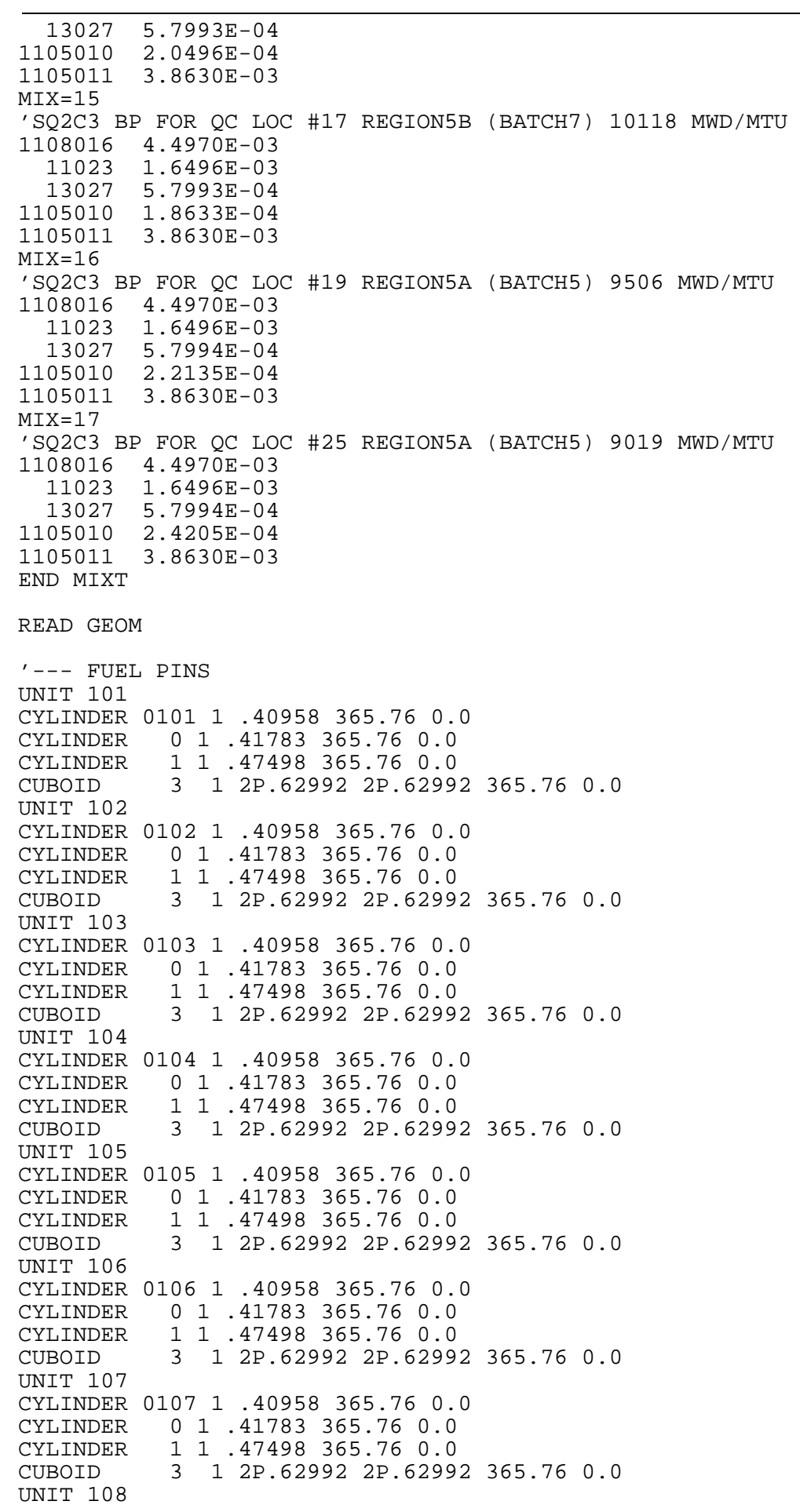


Table E.9 (continued)

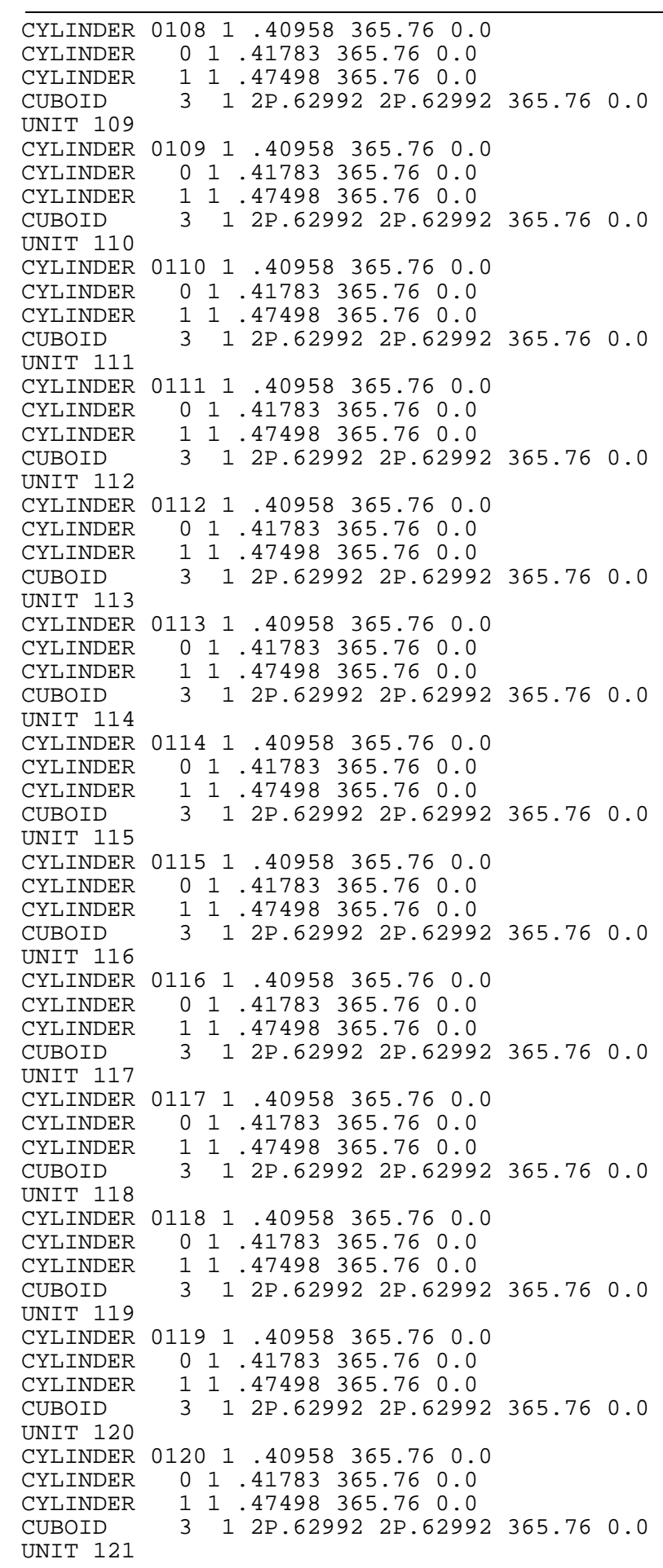


Table E.9 (continued)

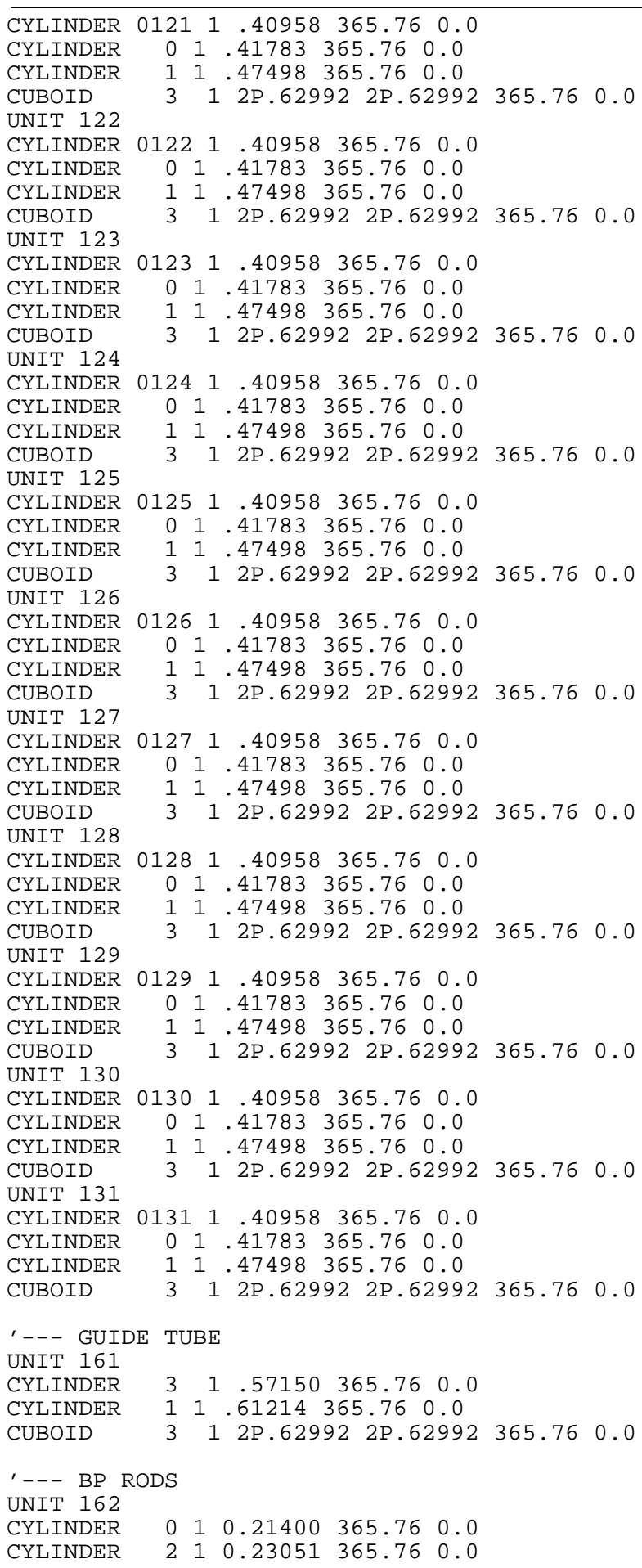


Table E.9 (continued)

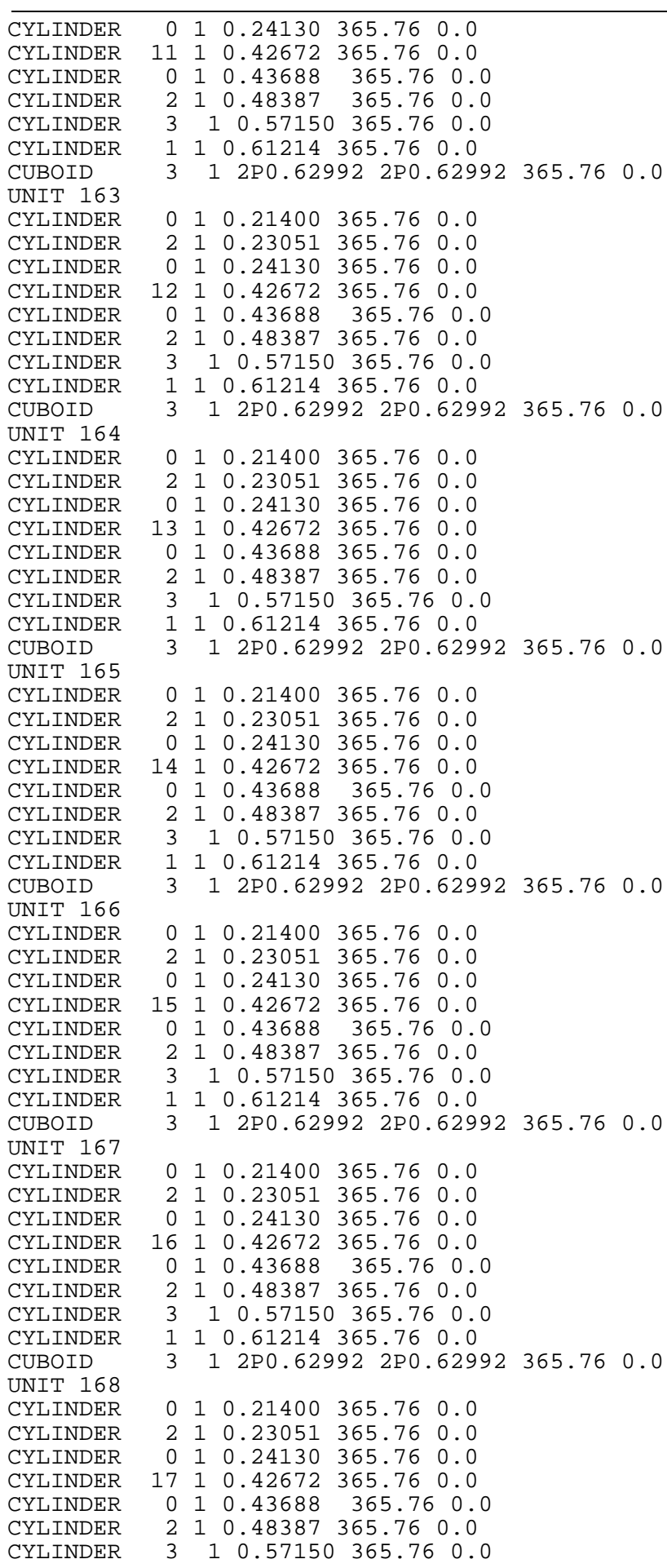




\section{Table E.9 (continued)}

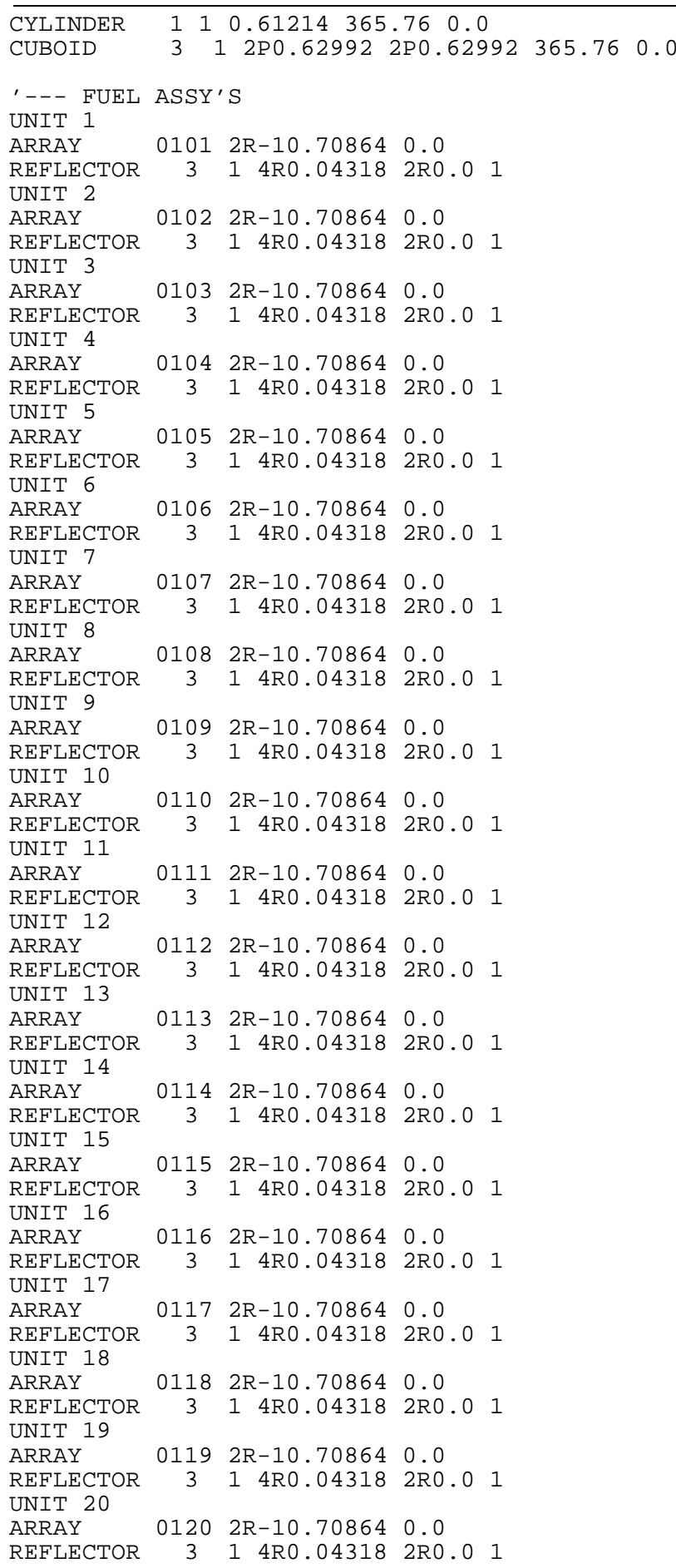


Table E.9 (continued)

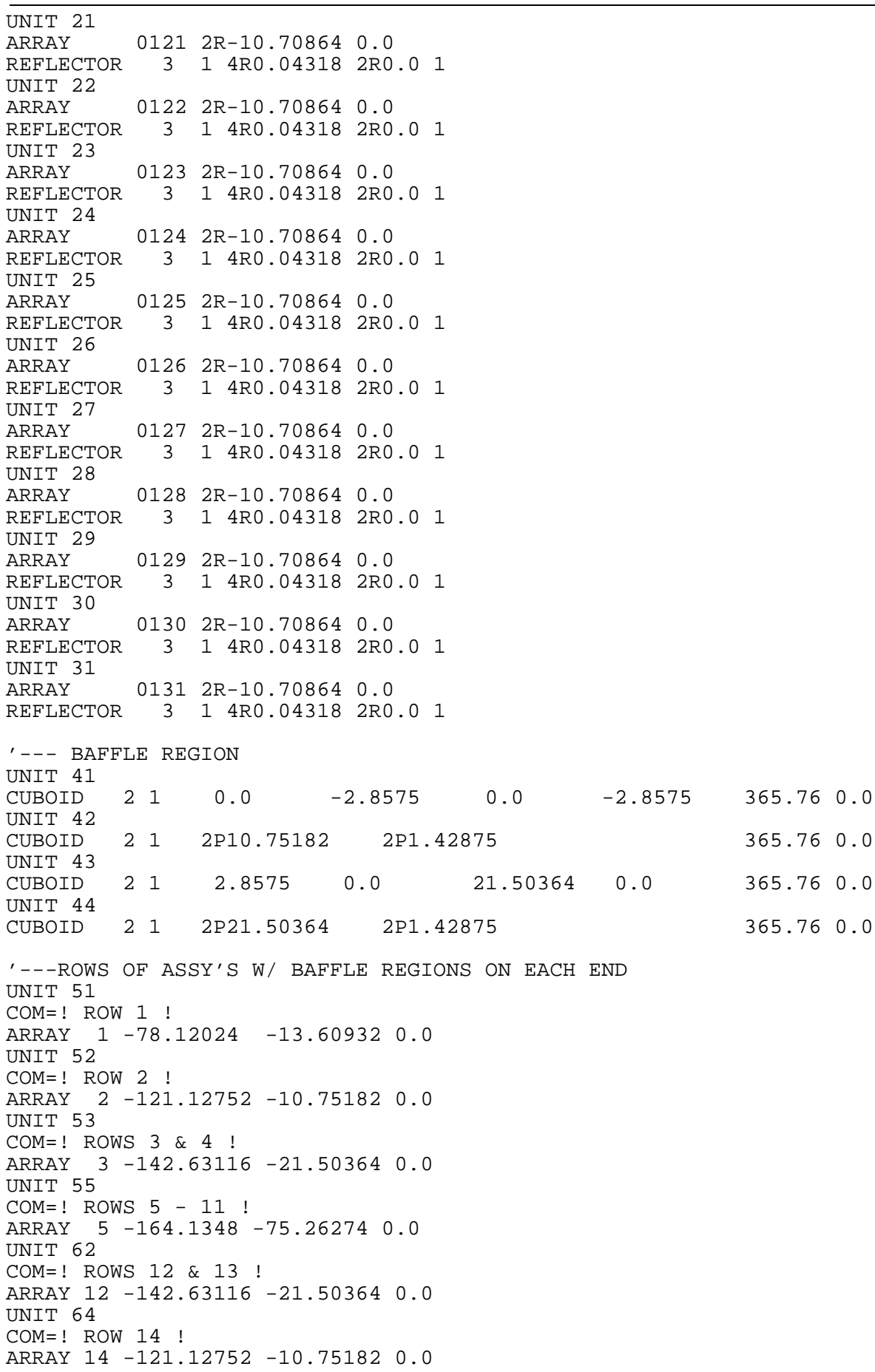


Table E.9 (continued)

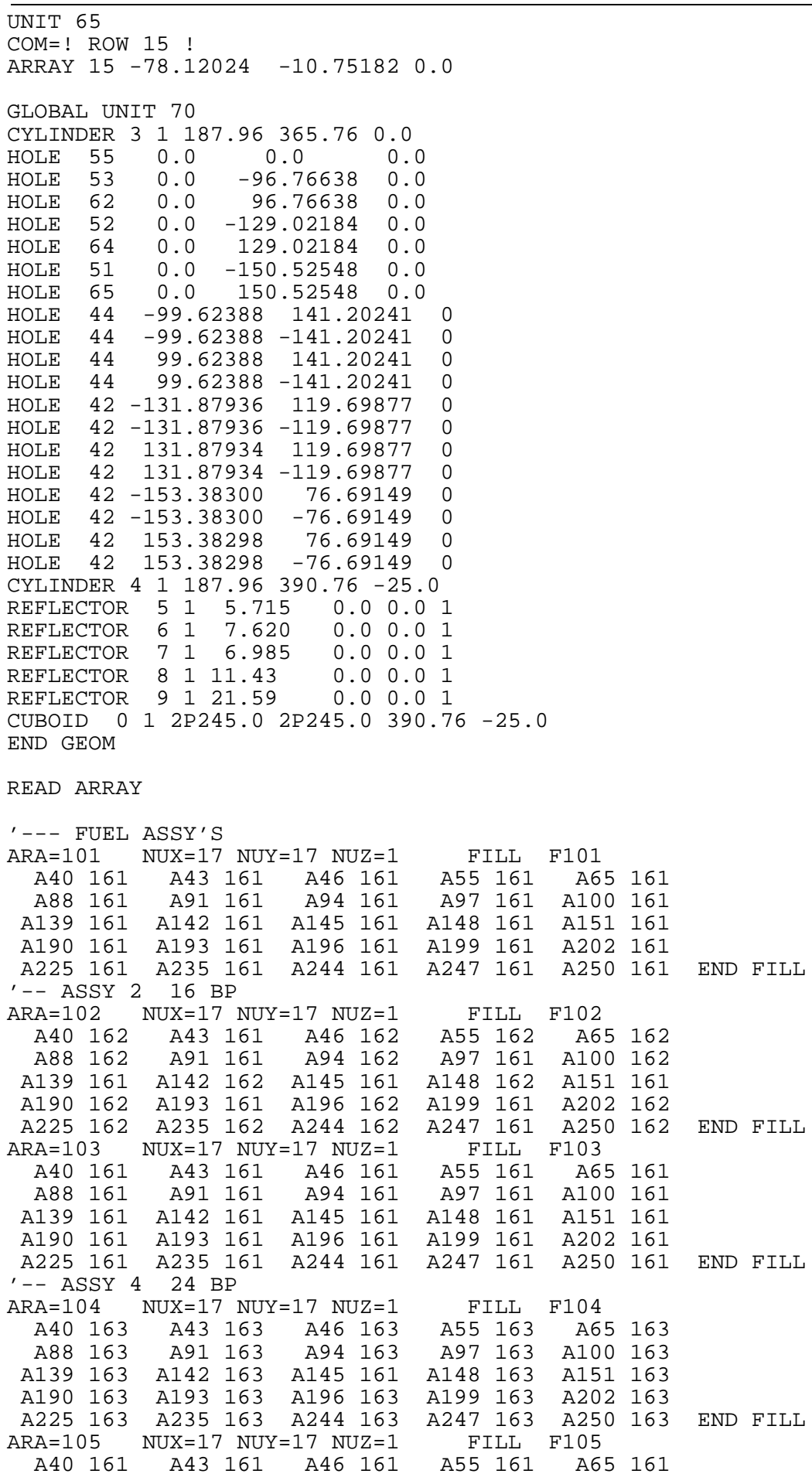


Table E.9 (continued)

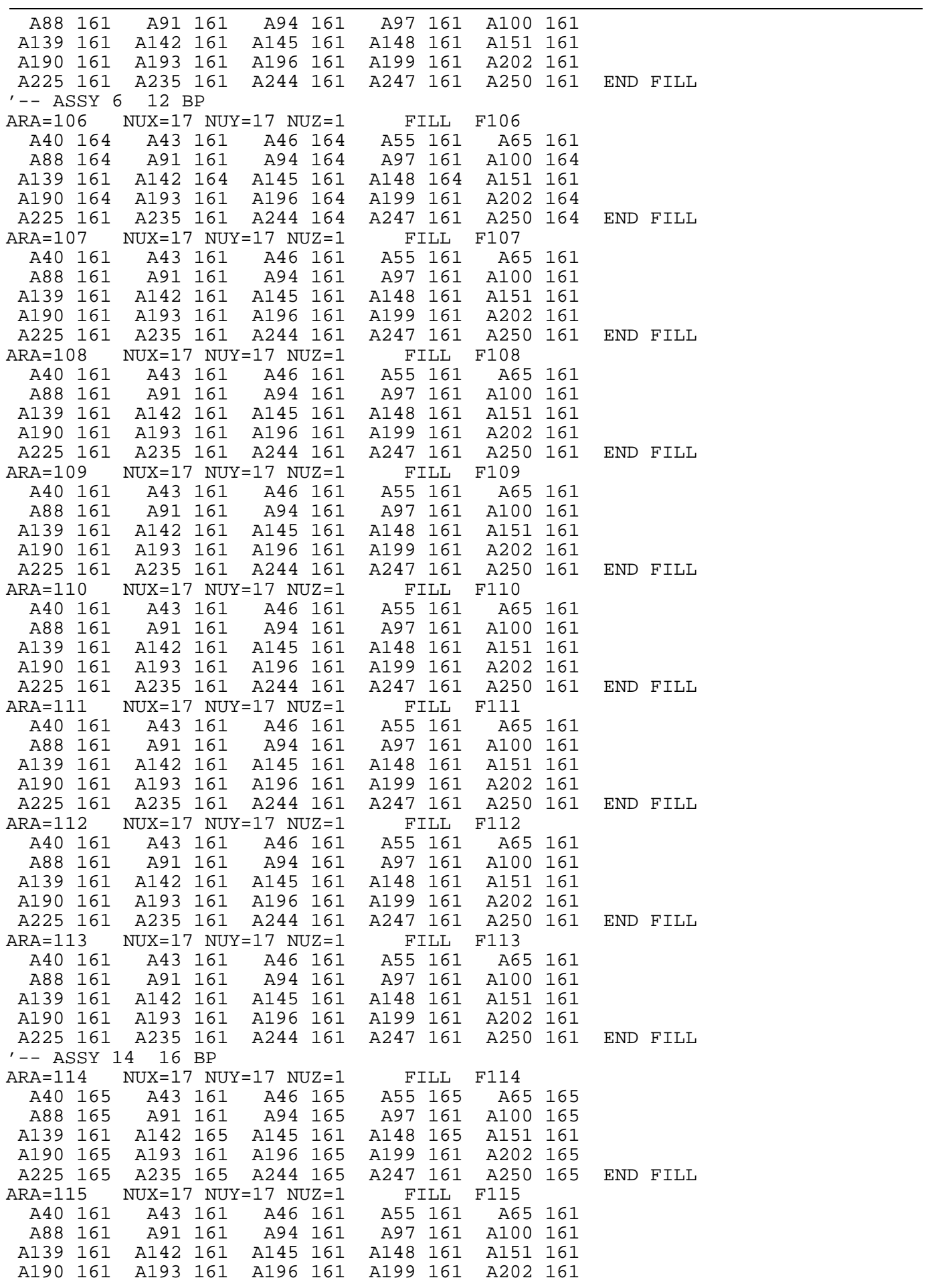


Table E.9 (continued)

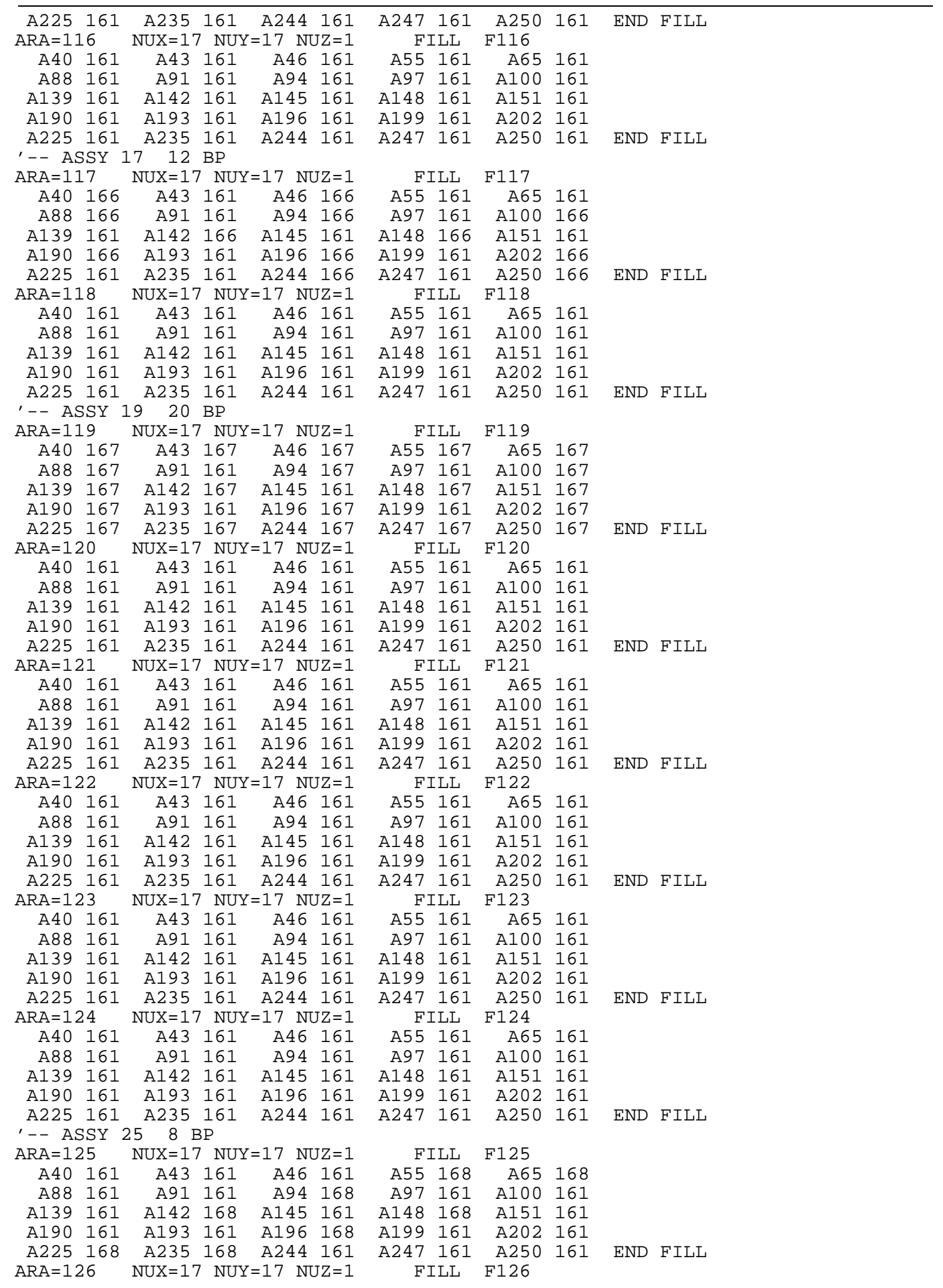


Table E.9 (continued)

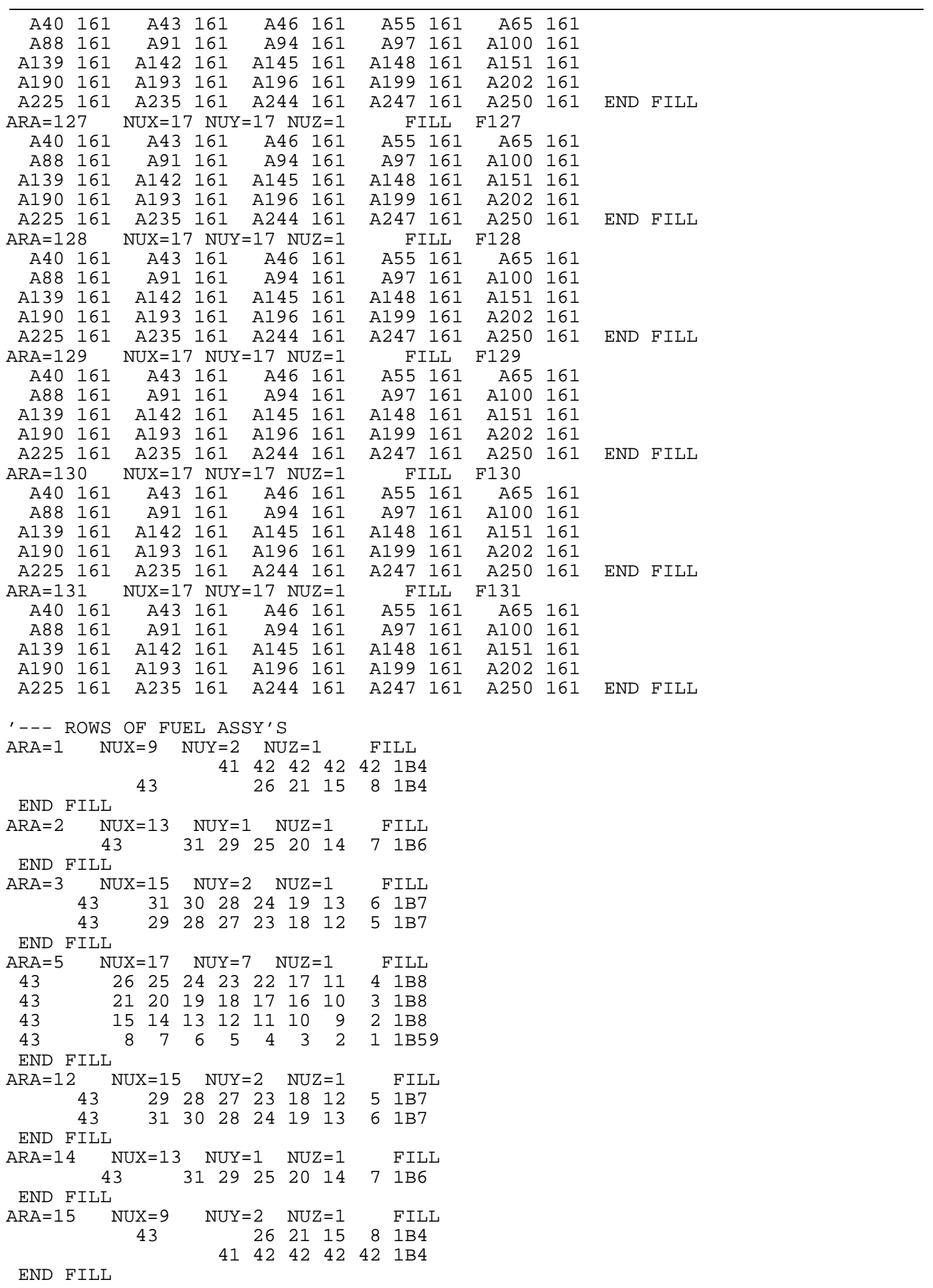


Table E.9 (continued)

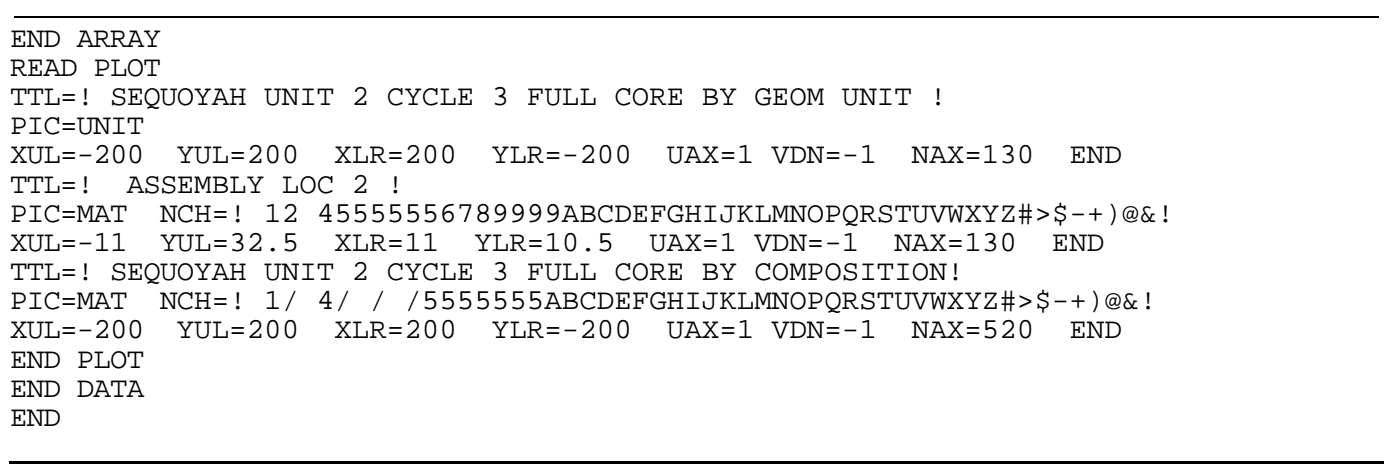


ORNL/TM-12294/V2

\section{INTERNAL DISTRIBUTION}

1. C. W. Alexander

2-3. S. M. Bowman

4. B. L. Broadhead

5. J. A. Bucholz

6. R. D. Dabbs

7-8. M. D. DeHart

9. M. B. Emmett

10. N. M. Greene

11. O. W. Hermann

12. M. Kuliasha

13. L. C. Leal

14. S. B. Ludwig

15. S. K. Martin

16. G. E. Michaels

17. B. D. Murphy

18-22. L. F. Norris

23. J. V. Pace
24-28. C. V. Parks

29. L. M. Petrie

30. R. T. Primm

31. J.-P. Renier

32. J. W. Roddy

33. R. W. Roussin

34. J. C. Ryman

35. C. H. Shappert

36. R. M. Westfall

37. B. A. Worley

38. R. Q. Wright

39-40. Laboratory Records Dept.

41. Laboratory Records, ORNL-RC

Document Reference Section

42. ORNL Y-12 Research Library

43. Central Research Library

44. ORNL Patent Section

\section{EXTERNAL DISTRIBUTION}

45. R. Anderson, General Nuclear Systems, Inc., 220 Stoneridge Dr., Columbia, SC 29210

46. M. G. Bailey, Office of Nuclear Material Safety \& Safeguards, U.S. Nuclear Regulatory Commission, MS TWFN 8F5, Washington, DC 20555

47. L. Barrett, Office of Civilian Radioactive Waste Management, RW-232 20545, U.S. Department of Energy, Washington, DC 20545

48. P. Baylor, Office of Civilian Radioactive Waste Management, RW-36, U.S. Department of Energy, Washington, DC 20545

49. C. J. Benson, Bettis Atomic Power Laboratory, P.O. Box 79, West Mifflin, PA 15122

50. J. Bickel, U.S. Department of Energy, Albuquerque Operations Office, P.O. Box 5400, Albuquerque, NM 87115

51. L. Blalock, U.S. Department of Energy, M-261 Quince Orchard, Washington, DC 20585-0002

52. J. Boshoven, GA Technologies, Inc., P.O. Box 85608, 10955 John J. Hopkins Dr., San Diego, CA 92121

53. M. C. Brady, Sandia National Laboratories, 101 Convention Center Drive, Suite 880, Las Vegas, NV 89109

54. P. Bunton, U.S. Department of Energy, RW-1, Washington, DC 20545

55. R. J. Cacciapouti, Yankee Atomic Electric Co., 1617 Worcester Rd., Framington, MA 01701

56. R. Carlson, Lawrence Livermore National Laboratory, P.O. Box 808, Livermore, CA 94550

57. C. R. Chappell, U.S. Nuclear Regulatory Commission, Office of Nuclear Materials Safety and Safeguards, TWFN 8F5, Washington, DC 20555

58. J. S. Choi, Lawrence Livermore National Laboratory, P.O. Box 808, Livermore, CA 94550

59. J. Clark, 2650 Park Tower Drive, Suite 800, Vienna, VA 22180 
60. J. Conde, Consejo de Seguridad Nuclear, Justo Dorado, 11, 28040 Madrid, Spain

61. D. R. Conners, Bettis Atomic Power Laboratory, P.O. Box 79, West Mifflin, PA 15122

62. M. Conroy, U.S. Department of Energy, M-261 Quince Orchard, Washington, DC 20585-0002

63. P. J. Cooper, Sandia National Laboratories, P.O. Box 5800, Albuquerque, NM 87185-0716

64. W. Davidson, Los Alamos National Laboratory, Group A4, MSF-611, Los Alamos, NM 87845

65-67. F. J. Davis, Sandia National Laboratories, P.O. Box 5800, Div. 6302, MS 1333, Albuquerque, NM 87185-0716

68. D. Dawson, Transnuclear, Inc., 2 Skyline Dr., Hawthorne, NY 10532-2120

69. T. W. Doering, TESS, B\&W Fuel Co., MS 423, Suite 527, P.O. Box 98608, 101 Convention Center Drive, Las Vegas, NV 89109

70. R. Doman, Nuclear Packaging, Inc., 1010 S. 336th St., Suite 220, Federal Way, WA 98003

71. E. Easton, U.S. Nuclear Regulatory Commission, Office of Nuclear Materials Safety and Safeguards, Washington, DC 20555

72. R. C. Ewing, Sandia National Laboratories, P.O. Box 5800, Div. 6643, MS 0716, Albuquerque, NM 87185-0716

73. C. Garcia, U.S. Department of Energy, Albuquerque Operations Office, P.O. Box 5400, Albuquerque, NM 87115

74. S. Hanauer, U.S. Department of Energy, RW-22, Washington, DC 20545

75. C. Haughney, U.S. Nuclear Regulatory Commission, Office of Nuclear Materials Safety and Safeguards, TWFN 8F5, Washington, DC 20555

76. L. Hassler, Babcock \& Wilcox, P.O. Box 10935, Lynchburg, VA 24506-0935

77. E. Johnson, E. R. Johnson Associates, Inc., 9302 Lee Hwy, Suite 200, Fairfax, VA 22031

78. R. Kelleher, International Atomic Energy Agency, Division of Publications, Wagramerstrasse 5, P.O. Box 100, Vienna, Austria A-1400

79. R. Kidman, Los Alamos National Laboratory, Group A4, MSF-611, Los Alamos, NM 87845

80. C. Kouts, Office of Civilian Radioactive Waste Management, RW-36, U.S. Department of Energy, Washington, DC 20545

81. S. Kraft, Nuclear Energy Institute, 1776 I Street, Suite 400, Washington, DC 20086

82. P. Krishna, TRW Environmental Safety Systems, 600 Maryland Ave. S.W., Suite 695, Washington, DC 20024

83. A. Kubo, 2650 Park Tower Drive, Suite 800, Vienna, VA 22180

84. W. H. Lake, Office of Civilian Radioactive Waste Management, U.S. Department of Energy, RW-46, Washington, DC 20585

85-87. R. Lambert, Electric Power Research Institute, 3412 Hillview Ave., Palo Alto, CA 94304

88-90. D. Lancaster, 2650 Park Tower Drive, Suite 800, Vienna, VA 22180

91. D. Langstaff, U.S. Department of Energy, Richland Operations Office, P.O. Box 550, Richland, WA 99352

92. D. Lillian, U.S. Department of Energy, M-261 Quince Orchard, Washington, DC 20585-0002

93. C. Marotta, 1504 Columbia Ave., Rockville, MD 20850

94. M. Mason, Transnuclear, Two Skyline Drive, Hawthorne, NY 10532-2120

95. J. Massey, Sierra Nuclear Corporation, 5619 Scotts Valley Drive, Number 240, Scotts Valley, CA 95066

96. W. Mings, U.S. Department of Energy, Idaho Operations Office, 550 2nd St., Idaho Falls, ID 83401

97. A. Mobashevan, Roy F. Weston, Inc., 955 L'Enfant Plaza, SW, 8th Floor, Washington, DC 20024

98. R. Morgan, 2650 Park Tower Drive, Suite 800, Vienna, VA 22180 
99. P. K. Nair, Manager, Engineered Barrier System, Center for Nuclear Waste Regulatory Analyses, Southwest Research Institute, 6220 Culebra Road, San Antonio, TX 78238-5166

100. D. Napolitano, Nuclear Assurance Corp., 5720 Peachtree Parkway, Norcross, GA 30092

101. C. W. Nilsen, Office of Nuclear Material Safety and Safeguards, U.S. Nuclear Regulatory Commission, MS TWFN-9F29, Washington, DC 20555

102. D. J. Nolan, 2650 Park Tower Drive, Suite 800, Vienna, VA 22180

103-104. Office of Scientific and Technical Information, U.S. Department of Energy, P.O. Box 62, Oak Ridge, TN 37831

105. Office of the Assistant Manager for Energy Research and Development, Department of Energy Oak Ridge Operations (DOE-ORO), P.O. Box 2008, Oak Ridge, TN 37831

106. C. E. Olson, Sandia National Laboratories, P.O. Box 5800, Div. 6631, MS 0715, Albuquerque, NM 87185-0716

107. N. Osgood, U.S. Nuclear Regulatory Commission, Office of Nuclear Materials Safety and Safeguards, TWFN 8F5, Washington, DC 20555

108. O. Ozer, Electric Power Research Institute, 3412 Hillview Ave., Palo Alto, CA 94304

109. P. Pacquin, General Nuclear Systems, Inc., 220 Stoneridge Dr., Columbia, SC 29210

110. T. Parish, Department of Nuclear Engineering, Texas A \& M University, College Station, TX 77843-3313

111-113. M. Rahimi, 2650 Park Tower Drive, Suite 800, Vienna, VA 22180

114. B. Rasmussen, Duke Power Co., P.O. Box 33189, Charlotte, NC 28242

115. T. L. Sanders, Sandia National Laboratories, P.O. Box 5800, Div. 6609, MS 0720, Albuquerque, NM 87185-0716

116. K. D. Seager, Sandia National Laboratories, P.O. Box 5800, Div. 6643, MS 0716, Albuquerque, NM 87185-0716

117. M. Smith, U.S. Department of Energy, Yucca Mountain Project Office, 101 Convention Center Dr., Las Vegas, NV 89190

118. M. Smith, Virginia Power Co., P.O. Box 2666, Richmond, VA 23261

119. K. B. Sorenson, Sandia National Laboratories, P.O. Box 5800, Div. 6643, MS 0716, Albuquerque, NM 87185-0716

120. F. C. Sturz, Office of Nuclear Material Safety \& Safeguards, U.S. Nuclear Regulatory Commission, MS TWFN 8F5, Washington, DC 20555

121. J. Sun, Florida Power \& Light Co., P.O. Box 029100, Miami, FL 33102

122. T. Suto, Power Reactor and Nuclear Fuel Development Corp., 1-9-13, Akasaka, Minato-Ku, Tokyo, Japan

123. R. J. Talbert, Battelle Pacific Northwest Laboratory, P.O. Box 999, Richland, WA 99352

124. T. Taylor, INEL, P.O. Box 4000, MS 3428, Idaho Falls, ID 83403

125. B. Thomas, VECTRA Technologies, Inc., 6203 San Ignacio Ave., Suite 100, San Jose, CA 95119

126. D. A. Thomas, B\&W Fuel Co., 101 Convention Center Drive, Suite 527, MS 423, Las Vegas, NV 89109

127. J. R. Thornton, TRW Enviornmental Safety Systems, 2650 Park Tower Dr., Suite 800, Vienna, VA 22180

128. G. Walden, Duke Power Co., P.O. Box 33189, Charlotte, NC 28242

129. M. E. Wangler, U.S. Department of Energy, EH-33.2, Washington, DC 20585-0002

130. R. Weller, U.S. Nuclear Regulatory Commission, TWFN 7J9, Washington, DC 20555

131. A. Wells, 2846 Peachtree Walk, Duluth, GA 30136

132. W. Weyer, Wissenschaftlich-Technische Ingenieurberatung GMBH, Mozartstrasse 13, 5177 Titz-Rodingen, Federal Republic of Germany

133. B. H. White, Office of Nuclear Material Safety \& Safeguards, U.S. Nuclear Regulatory Commission, MS TWFN 8F5, Washington, DC 20555 
134. J. Williams, Office of Civilian Radioactive Waste Management, U.S. Department of Energy, RW-46, Washington, DC 20545

135. M. L. Williams, LSU Nuclear Science Center, Baton Rouge, LA 70803

136. C. J. Withee, Office of Nuclear Material Safety \& Safeguards, U.S. Nuclear Regulatory Commission, MS TWFN 8F5, Washington, DC 20555

137. R. Yang, Electric Power Research Institute, 3412 Hillview Ave., Palo Alto, CA 94304 